University of Louisville

ThinkIR: The University of Louisville's Institutional Repository

Electronic Theses and Dissertations

8-2007

\title{
Cone beam computed tomographic simulation of panoramic radiology : third molar assessment and mandibular canal.
}

Ryan L. Snyder

University of Louisville

Follow this and additional works at: https://ir.library.louisville.edu/etd

\section{Recommended Citation}

Snyder, Ryan L., "Cone beam computed tomographic simulation of panoramic radiology : third molar assessment and mandibular canal." (2007). Electronic Theses and Dissertations. Paper 1358.

https://doi.org/10.18297/etd/1358

This Master's Thesis is brought to you for free and open access by ThinkIR: The University of Louisville's Institutional Repository. It has been accepted for inclusion in Electronic Theses and Dissertations by an authorized administrator of ThinkIR: The University of Louisville's Institutional Repository. This title appears here courtesy of the author, who has retained all other copyrights. For more information, please contact thinkir@louisville.edu. 


\title{
CONE BEAM COMPUTED TOMOGRAPHIC SIMULATION OF PANORAMIC RADIOLOGY: THIRD MOLAR ASSESSMENT AND MANDIBULAR CANAL
}

\author{
By \\ Ryan L. Snyder \\ D.M.D., University of Pittsburgh School of Dental Medicine, 1999
}

\author{
A Thesis \\ Submitted to the Faculty of the \\ Graduate School of the University of Louisville \\ In Partial Fulfillment of the Requirements \\ for the Degree of
}

Master of Science

Program in Oral Biology

School of Dentistry

University of Louisville

Louisville, Kentucky

August, 2007 


\title{
CONE BEAM COMPUTED TOMOGRAPHIC SIMULATION OF PANORAMIC RADIOLOGY: THIRD MOLAR ASSESMENT AND MANDIBULAR CANAL
}

\author{
By \\ Ryan L. Snyder \\ D.M.D., University of Pittsburgh School of Dental Medicine, 1999
}

A Thesis Approved on

May 15 th, 2007

by the following Thesis Committee:

ATlan G f́arman, BDS, PhD. DSC, Dipl ABOMR

Thesis Dhrector

William C. Scarfe, BDS, FRAĆCS, MS, Dipl ABOMR

James P. Scheetz MA, PhD 


\section{DEDICATION}

I would like to thank my family for their love and continued support throughout my educational and professional career in dentistry. 


\section{ACKNOWLEDGEMENTS}

I am greatly indebted to the following for their assistance on this project:

To Dr. Allan G. Farman, thesis director, for his help and guidance in leading me through the research process. He is the backbone of this project and helped tremendously to direct this project.

To Dr. William C. Scarfe, thesis committee member, for his valued insight and contributions throughout the work on this project.

To Dr. James Scheetz, chief statistician, for his insight into the data analysis. Thanks for your time and knowledge with helping me in the statistical analysis.

To Dr. Chandiramani for her efforts obtaining my data in this research. 


\title{
ABSTRACT \\ CONE BEAM COMPUTED TOMOGRAPHIC SIMULATION OF PANORAMIC RADIOLOGY: THIRD MOLAR ASSESSMENT AND MANDIBULAR CANAL
}

\author{
Ryan L. Snyder, DMD
}

May 15th, 2007

The aim of the research is to determine if cone beam computerized tomography reconstructed panoramic radiography viewed in two different focal trough shapes, and three different focal trough widths changes the ability to identify high risk radiologic signs associated with an intimate anatomic relationship between third molars and the Inferior Alveolar Nerve. The basic assumption of this research is that a customized focal trough shape with a wider focal trough width at the third molar region will produce more high risk radiologic signs present when there is a relation between the third molar and the Inferior Alveolar Canal.

A retrospective sample of 50 mandibular third molar teeth being less than $3 \mathrm{~mm}$ from the Inferior Alveolar Canal were picked from the files of the i-CAT CBVCT here at the University of Louisville Radiology Department. The 50 teeth were reconstructed into panoramic images with two different arch shapes (customized and average form), and three different focal trough widths at the third molar region $(10,20$, and $40 \mathrm{~mm})$. Six high risk radiological panoramic signs of the third molar related to the Mandibular canal will 
be evaluated at each tooth and determined to be present or absent by two independent observers. Each observer will also utilize the CBVCT cross sectional analysis of the mandible, measure the distance in $\mathrm{mm}$, the mandibular canal to the closest part of the mandibular third molar tooth. With these observations we will be able to determine the presence or absence of the high risk radiological signs and actually see if the teeth that have the high risk radiological signs are associated with the Inferior Alveolar Nerve, related to the focal trough image layer widths. This analysis will be compared in the two focal trough image layer shapes to determine if a average form of dentition focal trough shape will present more radiographic markers than the customized focal trough shape.

A Ordinal Logistic Regression will be performed to evaluate the relative impact of the predictor variables (radiographic signs, arch forms, and focal trough widths) to the outcome variables (distance of tooth to nerve-groups). Descriptive analysis will also be performed on each tooth to describe the comparison of radiological signs present, group that each tooth falls in related to distance of mandibular nerve in $\mathrm{mm}$ to the root of the third molar, whether nerve is buccal, lingual, or central to the root of the tooth, and if the nerve runs through the root, or the root is notched by the nerve.

For all tooth images, radiographic signs will be determined whether they are present or absent using two observers as independent experts to determine accuracy.

Ordinal logistic regression analysis will be used to measure the outcome of radiographic signs present with three categories (Cat. 1, 0-1 mm, Cat. 2, 1.001-2mm, Cat. 3, 2+mm). Intraclass correlation coefficient will be used as a measure of agreement to measure both inter and intra rater variability. With respect to intra-observer variability, inter-observer 
variability, there were significant differences in intra-observer and inter-observer variability. 


\section{TABLE OF CONTENTS}

PAGE

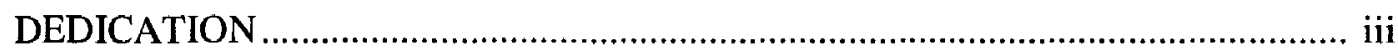

ACKNOWLEDGEMENTS .................................................................................

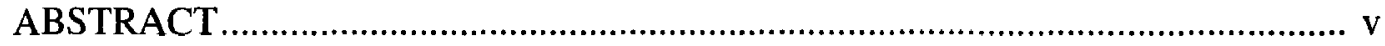

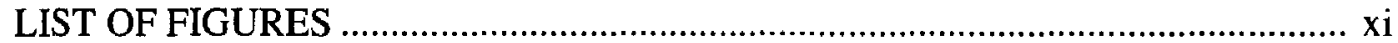

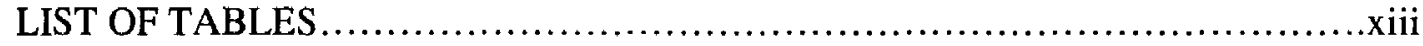

\section{CHAPTER}

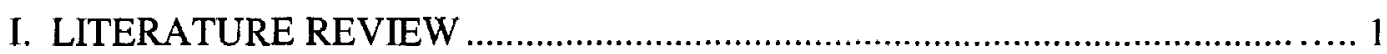

The incidence of third molar impaction .............................................................. 1

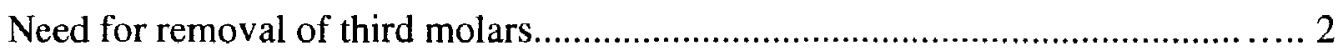

Reasons advanced to extract impacted mandibular third molar teeth

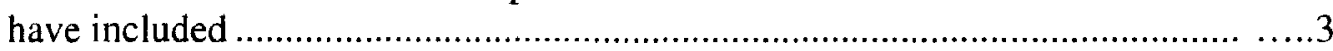

Nerve damage following third molar extraction............................................... 4

Classification of impacted third molars- angulation ..............................................

Classification of impacted third molars- depth ...................................................... 6

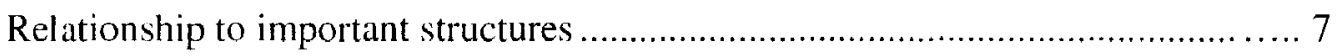

Imaging methods for third molar localization .................................................. 9

Value of panoramic imaging in identification and localization of the IAC........... 9

Standard form of dentition in mandible relating to panoramic

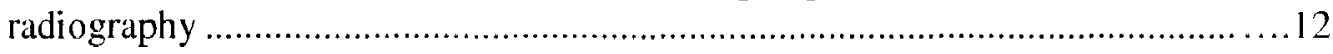

Arch widths in relation to panoramic focal trough widths ...................................14

Mandibular third molar impaction and panoramic radiographic

signs of IAN association 
Third molar analysis utilizing computerized tomography ...........................18

Cone Beam Volumetric Computed Tomography (CBVCT) ..........................22

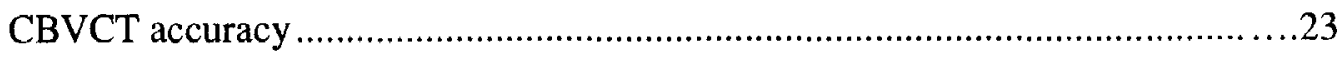

Third molar analysis utilizing CT (cone beam volumetric) ............................24

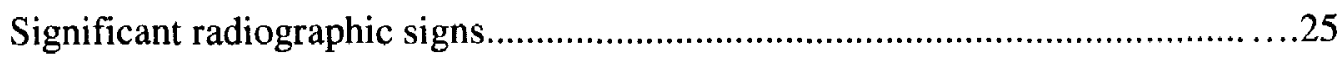

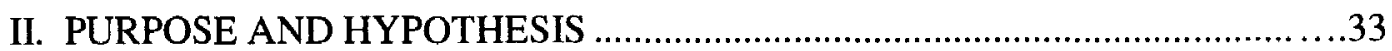

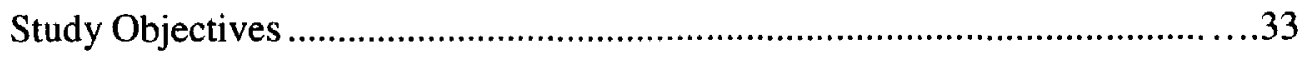

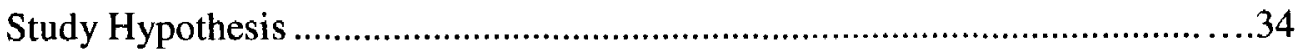

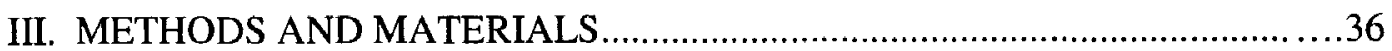

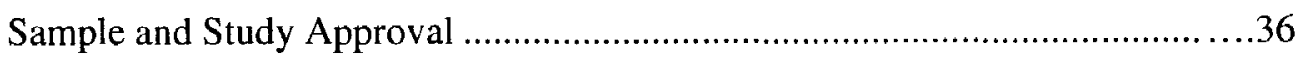

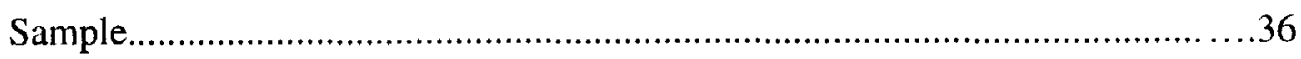

Panoramic reconstruction- customized focal trough....................................39

Panoramic reconstruction- average form of dentition of mandible

Welander, et al., 1989 panoramic reconstruction ........................................41

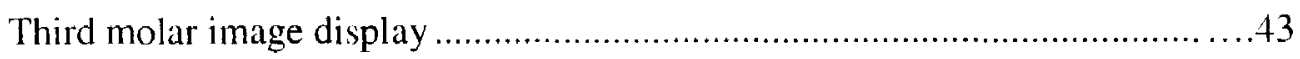

Determination of third molar relationship- subjective evaluation ................... +5

Determination of third molar relationship- objective evaluation....................47

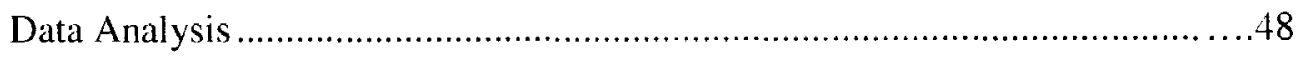

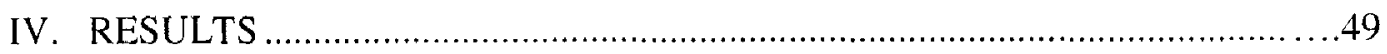

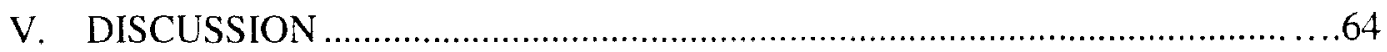

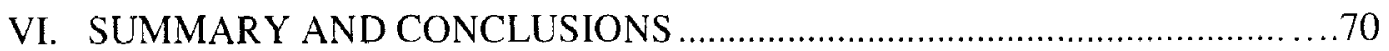




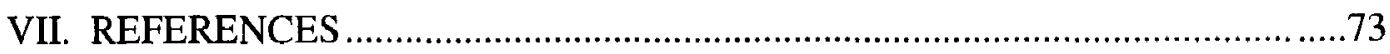

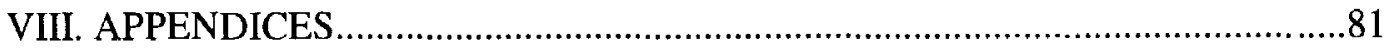

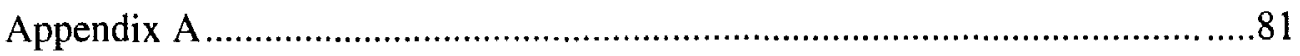

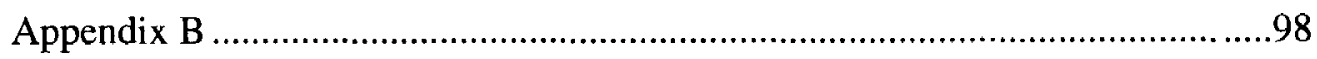

Appendix C........................................................ 119

Appendix D....................................................... 124

Appendix E...................................................... 129

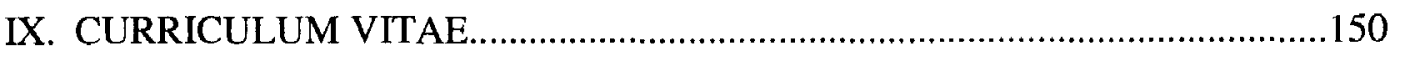




\section{LIST OF FIGURES}

FIGURE

PAGE

1. Focal plane form.......................................................... 10

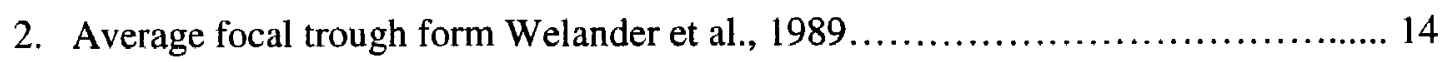

3. Radiographic sign-darkening of the root of the mandibular third molar.............27

4. Radiographic sign-interruption of the cortical white lines of

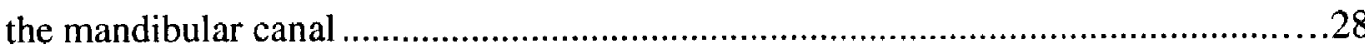

5. Radiographic sign-diversion or displacement of the inferior

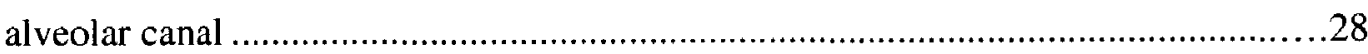

6. Radiographic sign-deflected roots of the mandibular third molar ..........................29

7. Radiographic sign-superimposition of the canal with the mandibular

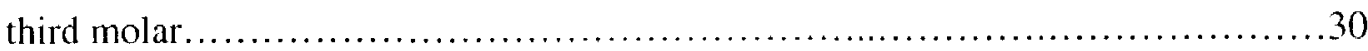

8. Radiographic sign-narrowing of the inferior alveolar canal....................... 30

9. Conventional i-CAT three planes of view: axial, sagittal, and coronal..............39

10. i-CAT display showing axial view with panoramic reconstruction

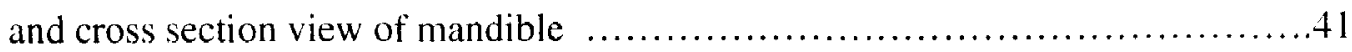

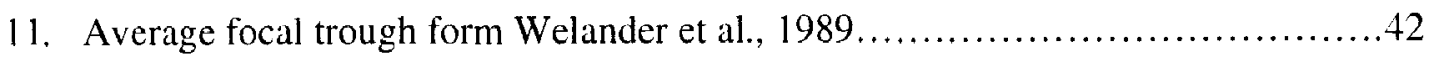

12. Acetate of average focal trough form Welander, et al., 1989

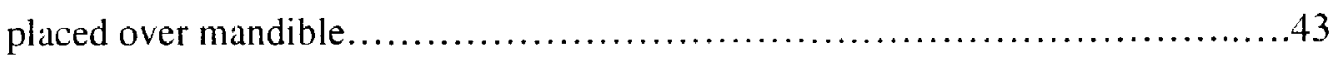

13. Cropped third molar image ............................................ 44 
14. Cross section of mandible to measure distance from root to IAN..

15. (A) Darkening of the root-customized focal trough shape- $20 \mathrm{~mm}$ focal trough width (B) Root of third molar communicating with nerve..

16. (A) Narrowing of the canal-customized focal trough shape-20mm focal trough width (B) Root of third molar communicating with nerve ................66

17. Average arch form focal trough................................................ 


\section{LIST OF TABLES}

TABLES

PAGE

1. Prevalence of impacted third molars in different populations......................... 1

2. Panoramic manufacturer and reported third molar focal trough width.............. 12

3. Significant panoramic radiological signs found in previous studies.................26

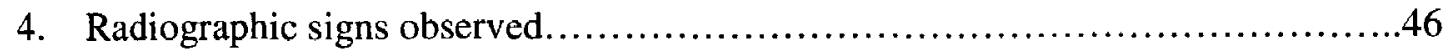

5. Distance from third molar root to inferior alveolar canal............................49

6. Buccolingual position of the mandibular canal in relation to root.................50

7. Incidence of radiographic signs of IAC involvement in relation to the root of the

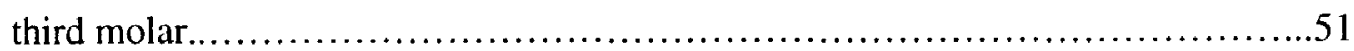

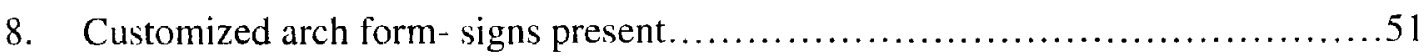

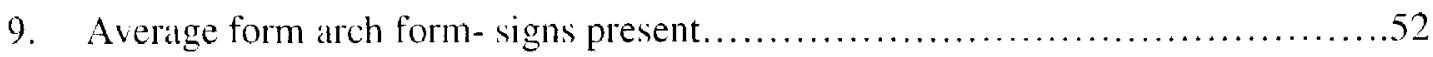

10. Type III Analysis of effects- trough width $20 \mathrm{~mm}$, customized arch form............52

11. ICC and ANOVA results comparing inter-rater agreement- sign I darkening of the root.................................................................

12. Inter-rater agreement -sign 2- disruption of the cortical white lines of the canal......54

13. Inter-rater agreement-sign 3- deviation of canal....................................54

14. Inter-rater agreement-sign 4- deflection of roots...............................54 
15. Inter-rater agreement-sign 5 - superimposition of canal.........................55

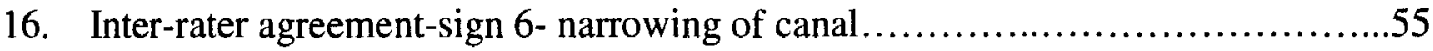

17. Inter-rater agreement- measurement of root to nerve, and nerve position..........55

18. Intra-rater agreement-sign \#1 - darkening of the root- observer \#1 $\ldots \ldots \ldots \ldots \ldots \ldots . . .57$

19. Intra-rater agreement-sign \#1- darkening of the root- observer \#2 _........................57

20. Intra-rater agreement-sign \#2- disruption of the cortical white lines of the

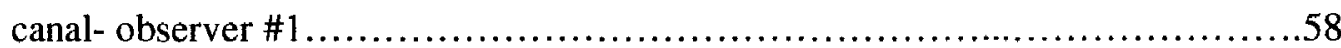

21. Intra-rater agreement-sign \#2- disruption of the cortical white lines of the

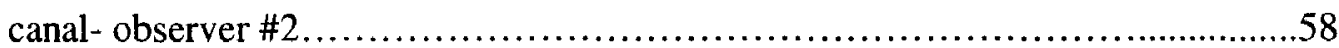

22. Intra-rater agreement-sign \#3- deviation of canal- observer $\# 1 \ldots \ldots \ldots \ldots \ldots \ldots . .59$

23. Intra-rater agreement-sign \#3- deviation of canal- observer \#2,...................59

24. Intra-rater agreement-sign \#4- deflection of roots- observer \#1 ...................60

25. Intra-rater agreement-sign \#4- deflection of roots- observer \#2

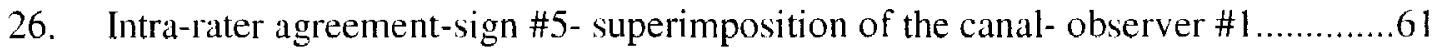

27. Intra-rater agreement-sign \#5- superimposition of the canal- observer \#2,.......61

28. Intra-rater agreement-sign \#6- narrowing of the canal- observer \#1 ..............62

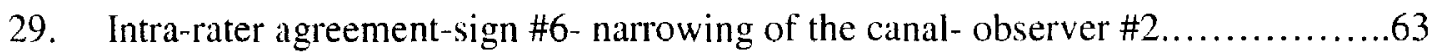


30. Intra-rater agreement-measurement of root to nerve, nerve position, and

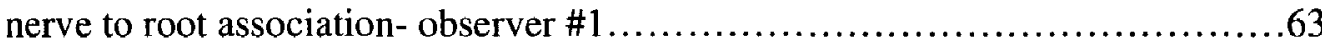

31. Intra-rater agreement-measurement of root to nerve, nerve position, and nerve to root association- observer $\$ 2$...................................6. 


\section{CHAPTER I}

\section{LITERATURE REVIEW}

\section{The Incidence of Third Molar Tooth Impaction}

Impaction of teeth is defined as "confinement of a tooth in the alveolus and prevention of its eruption into normal position"(Stedmans Medical dictionary, 1990). Impaction of dental teeth is common, with up to $20 \%$ of the general population demonstrating some degree of failure of eruption of present teeth.. Approximately $50 \%$ of all impacted teeth are third molars (Nordenram, 1986). Numerous authors have reported the prevalence of third molar impactions in different populations. (Table 1)

\section{TABLE 1}

Prevalence of impacted third molars in different populations

\begin{tabular}{llccc}
\hline Study & Population & Age group (yrs) & $\begin{array}{c}\text { Number of } \\
\text { subjects }\end{array}$ & $\begin{array}{c}\text { \% with one or } \\
\text { more impacted } \\
\text { third molar }\end{array}$ \\
\hline $\begin{array}{l}\text { Schersten } \text { et al. } \\
\text { (1989) }\end{array}$ & $\begin{array}{l}\text { Sweden; Dental } \\
\text { students }\end{array}$ & $20-39$ & 257 & 33 \\
$\begin{array}{l}\text { Morris and } \\
\text { Jerman (1971) }\end{array}$ & U.S.; Males & $17-24$ & 5600 & 65 \\
$\begin{array}{l}\text { Brickley et al. } \\
\text { (1996) }\end{array}$ & $\begin{array}{l}\text { Wales; Non-random } \\
\text { Olasoji and }\end{array}$ & $\geq 35$ & 264 & 29 \\
$\begin{array}{l}\text { Odusanya } \\
\text { (2000) }\end{array}$ & Nigeria; Urban & $\geq 20$ & 2400 & 23 \\
$\begin{array}{l}\text { Chu FCS, } \text { et al. } \\
(2003)\end{array}$ & $\begin{array}{l}\text { Hong Kong- } \\
\text { Chinese pop. }\end{array}$ & $\geq 17$ & 7486 & 28.3 \\
\hline
\end{tabular}


In a non-aged stratified study on 1,418 women in Sweden, $8 \%$ had impacted teeth and $85 \%$ of those teeth were third molars (Ahlqwist and Gröndahl, 1991). Chu, et al. (2003) studied 3,853 impacted third molar teeth, and found that mandibular third molars were the most commonly involved $(\sim 83 \%)$ followed by maxillary third molars $(\sim 18 \%)$.

\section{Need for Removal of Third Molars}

Removal of impacted third molars is the most common oral surgical procedure. In 2002 this procedure resulted in total expenditures in the range of $\$ 150-400$ million in the U.S. alone. Many investigators have questioned the necessity of removal of third molars for patients who are asymptomatic or free of associated pathoses (Chu, et al. 2003; Tulloch and Antczak-Bouckoms, 1987).

In Western society, dental professionals emphasize preventive dentistry. Hugoson and Kugelberg showed a sharp increase in the numbers of third molars extracted between 20-30 years of age principally due to prophylactic removal (Garcia and Chauncey, 1989; Hugoson and Kugelberg, 1988). However, dental insurance plans are frequently not covering prophylactic third molar removals. It has been suggested that antibiotics be used to treat infections associated with impacted third molars instead of removing the tooth concerned. According to Tate (1994), those who are making these suggestions do not understand the cyclic nature of these infections with the resulting occurrence of resistant organisms often leading to very serious infections. 


\section{Reasons advanced to extract impacted mandibular third molar teeth have included:}

In Sweden, Nordenram, et al. (1987) studied the indications for removal of 2,630

mandibular third molars. Reasons provided for extraction were pericoronitis (60\%), prophylactic indicators such as prediction of complications if the tooth remained (20\%), orthodontic indications $(\sim 11 \%)$, root resorption of adjacent molar $(\sim 5 \%)$, and cysts $(\sim 5 \%)$.

Other authors have also indicated additional indications for third molar extraction including 1) Pain due to partially erupted third molars and the possibility of infection that may accompany them (Nordenram, et al., 1987); 2) Periodontal considerations related to the position of the third molar-periodontal defects on the distal aspect of the mandibular second molars (Baab, 1964); 3) Pathologic resorption of the adjacent teeth (Yamaoka, 1999); 4) Potential for cyst formation and the possible association with neoplastic transformations and pathologic fractures (Tevepaugh and Dodson 1995); 5) Orthodontic considerations (e.g. the questionable crowding of lower incisors) (Kaplan 1974) and 6) The presence of third molars under prosthetic appliances (Rosenthal, 1986)

Although pressure resorption of second molars has been associated with impacted and/or erupting third molars, the relationship between such resorption and age is unclear. To investigate this relationship, Yamaoka et al. (1999) studied 3,174 individuals of various ages. There were no age or sex differences for the incidence of second molar root resorption. In older individuals, root resorption associated with a completely impacted third molar was more frequent than with a partially impacted third molar, and root resorption at the apex was mainly seen in individuals over 50 years of age. Apical 
root resorption may be seen long after the formation of completely impacted third molars in both sexes.

\section{Nerve Damage Following Third Molar Extraction}

Damage to the inferior alveolar nerve (IAN) is an uncommon complication, but an important one. Temporary disturbances of nerve function typically arise from injuries related to the stretching or crushing of the IAN. Severe crushing injuries associated with nerve impingement may be sustained indirectly, when elevating a tooth or more directly, damaging the nerve with a surgical instrument. Trauma to the IAN can result in a deficiency ranging from total loss of sensation (anesthesia), to a mild decrease in feeling (mild hypoesthesia). These sensory deficits may be either temporary or permanent. Some patients may also experience dysesthesia, which is characterized by abnormally painful sensations. Such pain may be caused by a neuroma that formed some time after the surgery located at the site of the trauma, changes in the autonomic nervous system (sympathetically mediated pain), or alterations in the central nervous system (central neuropathic pain).

Other types of sensory deficits patients may experience include: 1) allodynia, which is a type of dysesthesia characterized by a painful response to normally nonpainful stimuli, such as light touching or shaving; 2) hyperalgesia, which is an exaggeration of the pain response to stimuli; or 3) hyperpathia, which is an exaggerated response to pain that persists even after the stimulus has been removed (LaBanc, 1992). The treatment of these nerve injuries through IAN microsurgery is often unsuccessful, usually not bringing back normal sensation. 
There is a percentage of people that have disturbed sensations following third molar surgery and do have a sensation recovery after some time. Carmichael and McGowan (1992) report that the incidence of transient IAN damage ranges from $0.41 \%$ to $8.4 \%$ and permanent damage is reported to occur in $0.014 \%$ to $1.5 \%$ of cases. The presence of anesthesia, dysesthesia, or spontaneous pain also indicates a poor prospect for recovery. It has been reported that overall, $25 \%$ of patients with iatrogenic paresthesia suffer permanent effects (Zuniga and LaBanc, 1983). The risk of iatrogenic paresthesia of the third division of the trigeminal nerve depends on the procedure performed, the technique used, and the surgeon's experience. Iatrogenic paresthesia remains a complex clinical problem with major medico-legal implications.

\section{Classification of Impacted Third Molars}

\section{Angulation}

Tooth angulation provides an initial overview to the possible difficulty of the third molar extraction. This classification uses the angulation of the long axis of the impacted third molar in relation to the long axis of the second molar. There are four main groups based on angulation; namely: mesio-angular, horizontal, vertical, and disto-angular.

The mesio-angular impaction is usually the least difficult impacted mandibular third molar to remove. This third molar is tilted toward the second molar in a mesial direction. It is the most commonly presented third molar impaction and comprises about $43 \%$ of all impacted teeth (Peterson et al., 1993).

When the third molar is lying horizontal or perpendicular to the second molar, it is termed a horizontal impaction. This type of impaction is more difficult to remove than 
the mesio-angular impaction. Horizontal impactions present themselves less frequently and are seen only in approximately $3 \%$ of all mandibular impactions (Peterson et al., 1993).

In a vertical impaction, the third molar's long axis presents in the same direction as the second molar. This impaction occurs second in frequency, $38 \%$ of all impactions of mandibular third molar teeth, and is third in difficulty of removal (Peterson, et al., 1993).

The last of the four angulation groups for mandibular third molar is the distoangular impaction. This impaction presents itself with the long axis tilted distal to the second molar. This impaction is the most difficult to remove due to the path of removal involving the mandibular ramus. Disto-angular impactions are relatively uncommon as they account for only 6\% of all impacted third molars (Peterson, et al., 1993).

\section{Depth}

Pell and Gregory (1942) devised a classification for third molars that specifically allows the surgeon to carefully examine the relationship between the tooth and the anterior border of the ramus. Impacted mandibular third molars are divided into three groups: Class 1 - mesio-distal diameter of the crown is completely anterior to the anterior border of the mandibular ramus; Class 2 - mesio-distal diameter of the crown is one half covered by the ramus; Class 3 - the tooth is completely within the mandibular ramus. The order of difficulty is class 1 being the easiest and class 3 being the most difficult to remove surgically. 
Pell and Gregory (1942) also classified the depth of the impacted third molar compared with the height of the adjacent second molar tooth. This system is called the "Pell and Gregory A, B, and C classification." In this classification, the degree of difficulty is measured by the thickness of the overlying bone. As the tooth lies deeper in bone, it becomes less accessible, and harder to remove. Class A impactions have the occlusal surface of the impacted tooth level or nearly level with the occlusal plane of the adjacent second molar. Class B impaction occurs when the impacted third molar's occlusal surface is between the occlusal plane and the cervical line of the adjacent second molar. Class $\mathrm{C}$ impactions are when the occlusal surface of the impacted third molar is below the cervical line of the adjacent second molar tooth.

The three classification systems are used in conjunction with one another to describe the difficulty of the third molar extraction. For example a mesio-angular impaction with a Class I ramus and a Class A depth is considered easy to remove while a disto-angular impaction with a Class 3 ramus and a Class $\mathrm{C}$ depth is considered the most difficult to remove.

\section{Relationship to Important Structures}

In the mandible imaging is important in determining in assessing the likelihood of eruption and if extraction is envisaged, how difficult treatment will be prior to extracting impacted third molars. One of the complications that may occur following the extraction of mandibular third molars is injury to the inferior alveolar nerve. Injury to the inferior alveolar nerve has been related to deeply impacted teeth (Van Gool et al., 1977) and to roots in close approximation to the inferior dental canal (IDC) (Osborn et al., 1985). 
Thus, accurate assessment of the position of the inferior alveolar nerve in relation to the impacted third molar might reduce injuries to this nerve.

Anatomically, the nerve lies in the IDC which is enclosed within a tube of dense bone. The tube is seen on radiographs as two parallel radiopaque lines; one representing the roof of the canal and the other the canal floor. Oliver (1927) studied 50 dry specimens of mandibles and found in $60 \%$ of them a distinct IDC contained the whole of the inferior alveolar neurovascular bundle, while in the remaining $40 \%$ the vessels and branches of this bundle were spread out of the canal so a well-defined canal was not present. Carter and Keen (1971) radiographically examined 80 dried mandible specimens and found $61 \%$ of them showed a single bony canal with unbroken margins near the roots of molar teeth, while a bony canal with a broken upper wall was seen close to the molar roots in $14 \%$ of radiographs. The remaining $25 \%$ of the mandibles showed bony patterns lacking definite mandibular canals. Based on radiographic examination of a 100 edentulous human mandibles, Schroll (1975) concluded the position of the IDC was variable. This finding has been confirmed by Nortje et al. (1977a, b) who reviewed 3612 panoramic radiographs and found the position of the IDC was either touching or within 2 $\mathrm{mm}$ of the apices of molar teeth in $46.7 \%$ of the subjects. In $48.9 \%$ the IDC was touching or within $2 \mathrm{~mm}$ of the cortical plate of the lower border of the mandible and intermediately positioned between tooth apices and the lower border in $3.3 \%$ of the subjects. 


\section{Imaging Methods for Third Molar Localization}

To extract mandibular third molars, a surgeon must be able to have adequate information about the tooth and all surrounding structures. Traditionally, periapical radiographs and rotational dental panoramic radiographs have been used to assess the relationship between the IAN and the adjacent third molar roots before surgery Koong et al., (2006). There are numerous limitations in the use of periapical and panoramic radiographs, the most significant being an inability to determine three dimensional orientations due to absence of the bucco-lingual dimension. Due to such constraints, the uses of computed tomography (CT) (Ohman et al., 2006), MRI (Kress et al., 2004), and cone beam volumetric computed tomography (CBVCT) (Bouquet et al., 2004) have been introduced to display, in three dimension, the location and morphology of the IAN to the roots of the third molar.

\section{Value of Panoramic Imaging in Identification and Localization of the IAC}

Rotational dental panoramic radiography is a process in which the image of the dentition within curved dental arches is projected onto an X-ray image detector. This technique has been modified over time, but the basic concepts are still pertinent. The source of radiation in panoramic radiography is a vertically slit-collimated $\mathrm{X}$-ray beam that is used to scan the dentition. Due to the tomographic motion of the panoramic x-ray beam around the patient's head, an image of anatomy within a narrow zone of focus is produced. This "horseshoe" shaped zone of acceptably sharp anatomic structure is termed a focal trough or image layer. The focal trough of the panoramic X-ray unit is a 
three dimensional curved zone in which structures are reasonably well defined on the panoramic radiograph, and it is important for obtaining high quality images of the structures of interest (White and Pharoah, 2000). There is a single plane lingual to the center of the focal trough that produces optimal sharpness of the anatomic layer which is called the "focal plane" (sometimes misnamed the "central plane") in which the horizontal and vertical magnifications are distorted only by vertical projection geometry. This focal plane form is made by various points between the set focus and the plane of the image detector (e.g. indirect exposure X-ray film), various osseous structures will be projected on the detector at the exact same speed (or virtual movement) of the detector that is being used. (Figure 1) The points represent one half the path described by the plane of highest resolution in each machine.

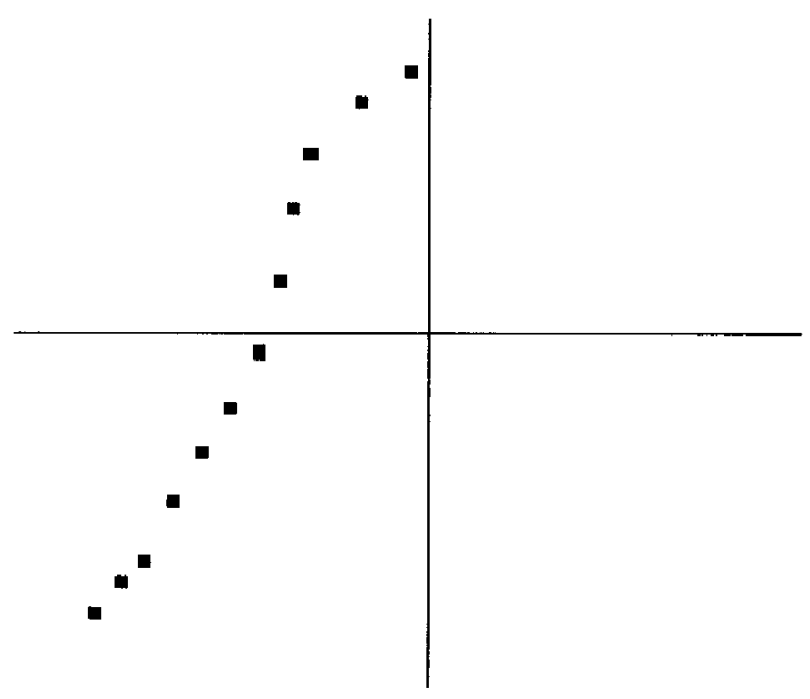

FIGURE 1 Focal plane form made by various points between set focus and the plane of the image detector 
Anatomy to either side of the focal plane becomes progressively more blurred and distorted as it is displaced further from the plane of greatest spatial resolution due to detector changing velocities. This results in differences in projected image magnification. As structures progressively fall outside of the focal trough, the differences in magnification cause structures to appear too wide or too narrow depending on which side of the plane of highest resolution the structure is located.

The outside limits of this image layer are not completely clear. The amount of distortion or blurring that is acceptable is subjective. A value such as $0.5 \mathrm{~mm}$ for relative unsharpness can be used in calculations to determine the boundaries, or the subjective criteria as to what structures are in "sharp focus" may determine the boundaries in experimental studies (Glass, et al., 1985). The focal troughs usually vary in size and shape, depending on such factors as effective projection radius, the size of the beam, and the relative speed of the detector.

Various manufacturers choose different shapes and sizes of the image layers for their panoramic radiograph machines. They often base their selection on the average dental arch having the focal trough bounded by acceptable resolution limits at $1.5 \mathrm{lp} / \mathrm{mm}$. (Welander et al., 1989). (Table 2) 


\section{TABLE 2}

Panoramic manufacturer and reported focal trough width in the region of the mandibular third molar

\begin{tabular}{lllll}
\hline $\begin{array}{l}\text { Manufacturer/ } \\
\text { Model }\end{array}$ & $\begin{array}{l}\text { Planmeca } \\
\text { Oy. } \\
\text { Dimax 3 }\end{array}$ & $\begin{array}{l}\text { Gendex } \\
\text { Orthoralix } \\
\mathbf{9 2 0 0}\end{array}$ & $\begin{array}{l}\text { J. Morita } \\
\text { Veraviewepocs } \\
\text { SD }\end{array}$ & $\begin{array}{l}\text { Instrumentarium } \\
\text { OP 100 }\end{array}$ \\
\hline $\begin{array}{l}\text { Focal trough } \\
\text { width }\end{array}$ & $25 \mathrm{~mm}$ & $15 \mathrm{~mm}$ & $13 \mathrm{~mm}$ & $26 \mathrm{~mm}$ \\
\hline
\end{tabular}

Due to the information that can be obtained from a panoramic radiograph, its use is often considered of value in the presurgical planning for the removal of impacted mandibular third molar teeth. The different shapes and sizes of the image layers have been determined, both mathematically and experimentally (Glass, et al. 1985). McDavid and colleagues (1981) concluded that the location of the focal plane of the image layer and the thickness of the image layer are very sensitive to even very small deviations in receptor speed and machine synchronization.

\section{Standard form of the dentition in mandible relating to panoramic radiography}

There are many panoramic radiographic machine models. Each has its own unique movement pattern with differences in image layer size, shape and width, all of which are all designed to capture and display the same structures.

Most panoramic units have only one pre-selected movement pattern. This movement produces an image layer that is designed to fit the "average" patient. However, not every patient has the same jaw size and shape. Deviations in size and form 
of an individual jaw from a pre-selected image layer will result in varying degrees of distortion and unsharpness (Welander, et al., 1989). Several analyses have been made to study variations of the size and form of dental arches (Nummikoski, 1985; Lund and Manson-Hing, 1975; Manson-Hing, et al., 1976) however, few studies have investigated the clinical effects of variations in focal trough dimensions on the diagnostic efficacy of panoramic radiography.

Information on the dimensions of the average dentition and mandible has been reported by Nummikoski et al. (1985). In their study, the forms of the dentition and the mandible were traced, taking into account not only the clinical crowns, but also the intrabony roots. The focal plane should be the average of both so that the dental arches fall within it. In a later study, Welander et al. (1989) studied average curves of the dentition in several different races and determined the average shape of the dentition and mandibular curves as polynomials. These were used to develop an average focal trough form. (Figure 2) These polynomials are used by various panoramic companies to produce a central plane for their panoramic systems which matches the average form of the dentition. 


\section{FIGURE 2}

Average focal trough form from Welander et al. (1989)

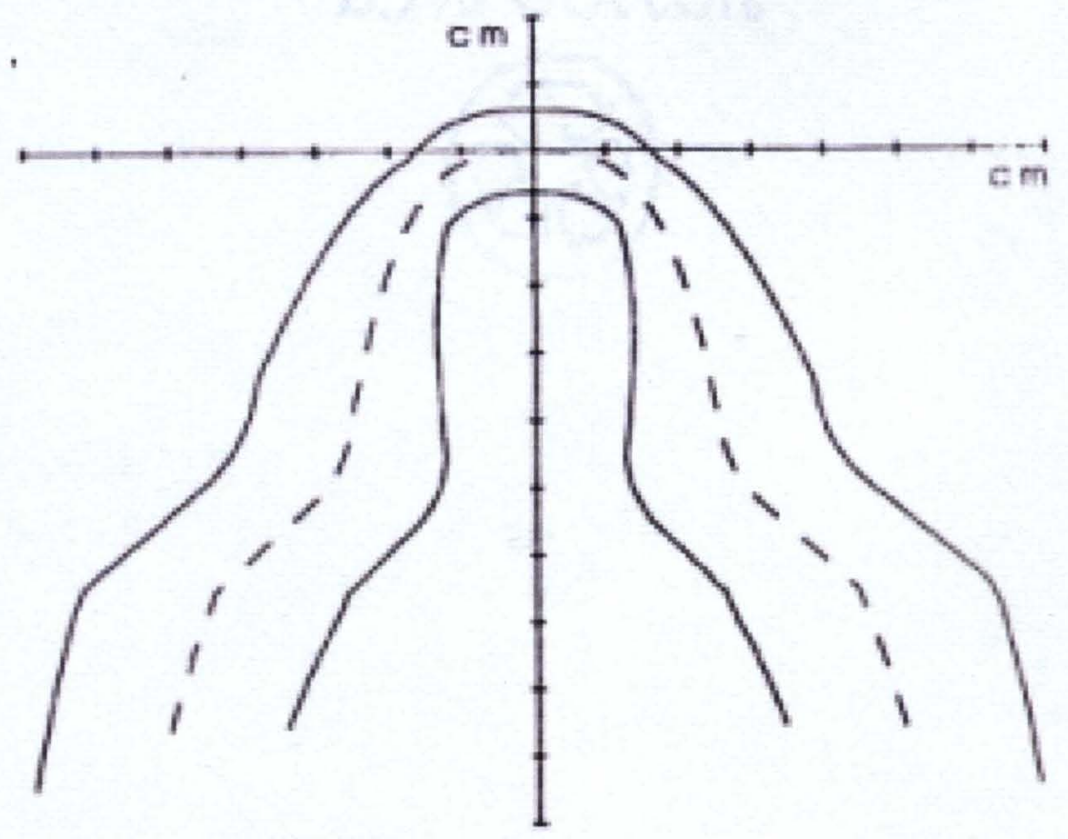

\section{Arch widths in relation to panoramic focal trough widths}

Most rotational panoramic machines have been designed with the assumption that there is no significant variation in mandibular size between races and sexes. However, Nummikoski et al. (1988) determined that ethnic and sexual differences in the dental and mandibular arch widths were statistically significant. Male dental arch forms were, on average, 0.6 to $1.1 \mathrm{~mm}$ wider than female arch forms. Their investigation found differences of 8 to $10 \mathrm{~mm}$ in dental arch widths between the minimum and maximum values and reported differences of about $15 \mathrm{~mm}$ in the position of the mandibular condyles, respectively even within the same sex (Nummikoski et al., 1988). Whether this 
deviation is sufficient to cause blurring of clinical significance in panoramic images depends on if the shape of the jaws coincident with the least distorted plane of the focal trough of a machine. If the jaw outline is coincident with the outer limits from the "least distorted plane", especially towards the lingual, a small deviation would make a difference. Points lingual and buccal to the sharpest plane lose sharpness as they progress farther from the plane, with lingually positioned points losing more sharpness than buccal points that are an equal distance from the sharpest plane.

\section{Mandibular third molar impaction and panoramic radiographic signs of IAN association}

When panoramic radiography is the only imaging modality used to assess the location of third molars. Proper assessment is essential to minimize morbidity. Unfortunately, interpretation of complex three dimensional anatomical relationships is often impossible due to inherent limitations associated with two dimensional conventional imaging systems (Danforth et al., 2003)

Panoramic imaging has been, until recently, the standard radiologic examination used to evaluate the anatomic relationship of third molars and the IAN (Smith et al. 1997). When utilizing a panoramic radiograph, a number of radiographic signs have been reported as being associated with increased or "high risk" for proximity of the tooth to the IAN. Valmaseda-Castellon and Berini-Aytes (2001) studied the correlation between interpretation of panoramic radiographs and treatment outcomes of 1,117 mandibular third molar cases post extraction. They found that IAN damage increases 
with patient age, deflection of the molar roots when approaching the IAN, and the need to perform a distal ostectomy.

Blaeser and colleagues (2003) estimated the association between specific panoramic radiographic signs and IAN injury during mandibular third molar surgery. They used a case control study design and the sample consisted of patients who underwent removal of impacted mandibular third molars. Cases were defined as patients with confirmed IAN injury after third molar extraction, and controls were defined as patients without nerve injury. Five surgeons, who were blinded to injury status, independently assessed the preoperative panoramic radiographs for the presence of high risk radiographic signs including: diversion or bending of the canal, darkening of the tooth root, and interruption of the cortical white line of the canal. Bivariate analyses were completed to assess the relationship between radiographic findings and IAN injury. They found 8 cases with IAN injury and 17 controls. They indicated that panoramic findings of diversion of the inferior alveolar canal, darkening of the third molar root, and interruption of the cortical white lines are statistically associated with IAN injury. Based on the estimated predictive values in this study, the absence of positive radiographic signs was associated with a minimal risk of nerve injury, whereas, the presence of one or more of these signs was associated with an increased risk for IAN injury.

According to Bell (2004), the sensitivity and specificity in diagnosis of an intimate relation between the root of the mandibular third molar tooth and the IAN were $66 \%$ and $74 \%$, respectively. When an intimate relationship is present, the relationship should be accurately diagnosed in $66 \%$ of the cases. With a specificity of $74 \%$, an intimate relationship does not exist in $74 \%$ of the cases that present with no contact 
between the root of the tooth and the IAN. Given these percentages of sensitivity and specificity, panoramic radiographic imaging does not appear to be an accurate diagnostic tool for third molar surgery planning. They state that this sensitivity and specificity in diagnosing the presence or absence of an intimate relationship between root and nerve using a panoramic radiograph is unreliable. Given this low diagnostic accuracy, it has been questioned whether use of panoramic radiographic imaging to determine mandibular third molar relationship to the IAN influences surgical outcome. In their study they had a surgeon view 300 mandibular third molar teeth and recorded the radiological observations (seven of them) of the third molars and the IAN. Every tooth had a radiological sign present. The same surgeon removed the teeth and recorded their relationships to the IAN. Out of the 300 teeth removed, the neurovascular bundle was directly observed, the root was grooved, or the root's apices were deflected by the nerve bundle in 35 of the cases. Overall, they concluded that there was an intimate relationship between the mandibular third molar tooth and the IAN in $12(51 \%)$ cases when darkening of the root was observed, and in only $11(11 \%)$ cases when interruption of the radioopaque outline of the inferior alveolar neurovascular bundle (along with superimposition) was observed. In this study, the most common radiographic appearance of a relationship between the mandibular third molar tooth and the IAN was superimposition in $110(37 \%)$ out of the total 300 teeth. There were occasional combinations of radiographic signs, all with darkening of the root combined with deflection of root, narrowing of the root, and narrowing of the canal. All but one of these groups of combined radiographic signs was in the $35(12 \%)$ cases where an intimate relationship between root and nerve was observed during surgery. 
Sedaghatfar and colleagues (2005) studied 230 patients from whom 423

mandibular third molars were extracted. The primary predictor variable was the presence or absence of panoramic radiographic signs associated with an increased risk for IAN injury. The outcome variable of this study is defined as direct visualization of the IAN at the time of the third molar extraction. The frequency of the panoramic radiographic signs were: 1) darkening of the root, $\mathrm{n}=72$ third molars (17\%), 2) interruption of the cortical white lines of the mandibular canal, $\mathrm{n}=152$ third molars $(35.9 \%), 3)$ diversion of the inferior alveolar canal, $\mathrm{n}=53$ third molars $(12.5 \%), 4)$ deflection of the roots, $\mathrm{n}=59$ third molars (13.9\%), and 5) narrowing of the roots, $\mathrm{n}=50$ third molars (11.8\%). Post extraction of the mandibular third molars, the IAN was visualized by the surgeon in 24 $(5.7 \%)$ cases. Overall, $3(0.7 \%)$ third molar extractions had evidence of IAN injury based on patient report and a neurosensory examination. All cases of IAN injury resolved within 1 year. It was determined that four of the radiographic signs were statistically associated with IAN exposure $(\mathrm{P}<.001)$. These were darkening of the root, interruption of the cortical white lines of the mandibular canal, diversion of the inferior alveolar canal, and narrowing of the roots. Deflection of the roots was not statistically associated with inferior alveolar nerve exposure. They found found that as the number of signs increases, the relative risk of IAN exposure also increases $(\mathrm{P}=.004)$. (Sedaghatfar, et al., 2005).

\section{Third molar analysis utilizing Computerized Tomography}

In the past two decades computerized tomography has been utilized to assess third molars that could be associated with the mandibular canal. Several studies have compared panoramic radiographs to $\mathrm{CT}$ scans in determining the position of the third molar to the 
IAN (Mahasantipiya et al., 2005; Bell, 2004; Maegawa et al., 2003; Monaco et al., 2004). These studies report high risk radiographic markers on a panoramic radiograph that may indicate a close tooth root relationship with the IAN; however, results have been inconsistent. As technology advances and prices of CT systems and procedures continue to drop, CT will likely become the standard for pre-surgical assessment of complicated third molar extraction cases that exhibit traditional high risk panoramic radiographic signs.

Monaco and colleagues (2004) conducted a study to evaluate the predictive value of five radiographic markers on panoramic radiographs to point out the relationship between the mandibular canal and the impacted third molar. They used 1 . superimposition of the tooth on the canal, 2. increased radiolucency, 3. interruption of the radio-opaque border of the canal, 4. diversion of the canal, 5. narrowing of the canal, on panoramic radiographs as radiographic markers, comparing them with an axial CT scan. They identified a sample of 73 third molars that showed a close relationship between the third molar roots and the mandibular canal on the panoramic radiograph, and then classified them on the basis of the five radiograph markers. They also detected contact between the third molar and the mandibular canal on the CT scan. Out of the 73 teeth examined, 37 molars exhibited increased radiolucency, 13 had superimposition, 14 showed interruption of the radio-opaque border, 14 exhibited narrowing of the canal and 7 showed diversion of the canal. In 11 cases, two or more markers were recognizable. The predictive values of a positive test result were molars with increased radiolucency $73 \%$, superimposition $38.5 \%$, interruption of the radio-opaque border $71.4 \%$, narrowing of the mandibular canal $78.6 \%$, and diversion of the mandibular canal $100 \%$. The 
authors also found that the third molar root apices had contact in all of the cases showing two or more radiographic markers. They concluded that increased radiolucency, narrowing and interruption of the radio-opaque border, as well as the presence of two or more radiographic markers were highly predictive of contact between the third molar and the mandibular canal. In these cases, a CT scan should be obtained. When compared with other studies, this study found a higher predictive value for diversion of the mandibular canal, however, because of the small sample size (seven cases of diversion of the canal), these results must be viewed with caution.

Mahasantipiya and colleagues (2005) determined the value of radiographic markers on rotational panoramic radiographs in assessing the true relationships of the IAN. They assessed the mandibular third molars using CT to determine the position and morphology of the IAN relative to the roots and the cortical plates. The radiographic markers on rotational panoramic radiographs were correlated with the CT findings to determine if there is an association with the IAN. There were 202 mandibular third molars in this study. Narrowing of the mandibular canal was found in relation to the mandibular third molars in $66.8 \%$ of the cases. The chance of narrowing of the mandibular canal as shown using CT increased when at least one of the radiograph markers, superimposition, narrowing, deviation or reduction in density was present on the rotational panoramic radiograph. Deviation of the mandibular canal on rotational panoramic radiographs was found to be the most significant predictor of narrowing of the canal to having a close relationship to the roots of the third molar and the mandibular canal. 
Even though panoramic radiographs display high risk signs before third molar removal, they are not sufficient to determine the relationship between the molar and the mandibular canal in 3D. They do not show what kind of surgical approach, buccal or lingual, to take when removing bone to remove the impacted third molar while avoiding injury to the IAN. Superimposition of the mandibular canal to the roots of third molars is often seen in periapical and panoramic radiographs. The parallax method of taking periapicals has been useful in evaluating whether or not the root and the mandibular canal contact each other. However, it is usually difficult to estimate their precise proximity Nakagawa et al. (2002) used cone beam volumetric computerized tomography (CBVCT) in assessment of a mandibular third molar before surgery. They had a rotational panoramic radiograph with third molar roots superimposed over the mandibular canal. Through CBVCT, the mandibular canal was confirmed to lie between the mesial and distal third molar roots. With this knowledge, extreme care could be taken to avoid injuring the contents of the mandibular canal.

Three dimensional assessments of surrounding structures and the anatomic location of the third molar are not possible when utilizing a panoramic or periapical radiograph. Today, more accurate diagnostic aids are available to assess third molars that are in close proximity to the IAN. CT allows the surgeon to gain an understanding of what structures are close to the proximity of surgery, minimizing the risk of nerve injuries during third molar surgery. The use of multi-slice CT has greatly enhanced the capability of CT to demonstrate the location and morphology of the IAN. Multi-slice scanners are much faster than conventional CT scanners and the reformatted images are as sharp as the directly acquired images. Consequently, there has been a significant 
increase in the number of cases being referred for pre-surgical evaluation using multislice CT to evaluate the relationship between the IAN and the lower third molar roots. Mahasantipiya et al., (2005) However, there are drawbacks to the use of this diagnostic aid. Multi-slice CT imaging is not readily accessible in all areas of the country and can be very costly to the patient (hundreds of dollars) if it is not covered by medical insurance. Also, the radiation dose that the patient receives can be high. Various publications have estimated the typical surface radiation doses to adults from multiple adjacent CT slices as 30-70 mGy per head scan series. (Nickoloff and Alderson, 2001) Although CT is better than the panoramic film, CT may still have imaging problems such as blurring, appropriate exposure techniques, imprecise site location, varying magnification, and image data is limited when provided a printout. This is adequate for routine cases but limiting for the complex cases where the potential for volume analysis and patient modeling could enhance the diagnostic process (Danforth et al., 2003).

\section{Cone Beam Volumetric Computed Tomography (CBVCT)}

Recently, cone beam volumetric tomography (CBVCT) has been introduced and developed especially for the oral and maxillofacial region (Mozzo et al., 1998; Hashimoto et al., 2003; Sukovic 2003; Baba et al., 2004). CBVCT uses rotational scanning by an X-ray source and reciprocation X-ray detector to facilitate acquisition of multiple single projection frame "basis" images. CBVCT allows two-dimensional (2D) multi-planar reformatting (MPR) and secondary reconstruction of the data within a personal computer, thereby allowing generation of images in orientations other than the conventional axial plane (Moshiri et al,, 2006). Developments in technology have made 
CBVCT specifically for the craniofacial region feasible and affordable. A single CBVCT exposure provides three dimensional information which assists in viewing anatomical detail, diagnosis, and treatment planning. Some of the advantages for using CBVCT technology in clinical practice include: X-ray beam limitation, image accuracy, rapid scan time, radiation dose reduction, display modes unique to maxillofacial imaging, and reduced image artifact.

The gap that exists between traditional panoramic film radiography and medical CT associated with high cost, radiation, and lack of 3-dimensional view is being answered with CBVCT. CBVCT provides alternatives to film panoramic radiography and medical CT by providing the dentist with lower dose radiation than medical CT (50 $\mu \mathrm{Sv}$, Newtom 9000 full volume scan), lower cost to patient $(\$ 150-\$ 250)$, and volumetric three dimensional imaging of the surrounding surgical third molar site (Danforth et al., 2003). However, CBVCT produces a higher radiation dose when compared to panoramic radiography. Ludlow et al., $(2003,2006)$ examined the radiation doses for the NewTom 9000 CBVCT machine and the Orthophos Plus DS panoramic unit. CBVCT examinations compared to panoramic radiography resulted in doses that were 3-7 times higher $\left(\mathrm{E}_{\mathrm{ICR} P 60}\right)$ and 2-4 times higher ( $\left.\mathrm{E}_{\mathrm{SAL}}\right)$ (Ludlow, et al., 2003).

\section{CBVCT accuracy}

A number of authors have recently reported on the accuracy of CBVCT in maxillofacial imaging. Hilgers et al. (2005) showed that condylar dimensions and various cephalometric landmarks are accurate when measured on CBVCT compared to the "truth" measured on dry skulls. In another study using dry skulls, Moshiri et al. (2006) 
compared measurements to those taken from both CBVCT images and traditional lateral cephalometric images. They showed that CBVCT images more accurately demonstrate actual measurements made directly on a skull than traditional lateral cephalometric radiographs Lascala et al. (2004) utilized the NewTom 9000 CBVCT machine and examined 13 measurements on the skull and scans. They showed that skull measurements were always larger than those on the CBVCT scan, but only significantly for internal structures of the skull base. Since these were the only structures that showed a significant difference, it was concluded that CBVCT scans are reliable for linear measurements of other structures that are more closely associated with dentomaxillofacial imaging.

\section{Third molar analysis utilizing CBVCT}

Pawelzik and colleagues (2002) evaluated the geometric, topographic, and anatomic reliability of volumetric computed tomography images by comparing conventional panoramic radiographs with reconstructed volumetric computed tomography panoramic and paraxial images before performing third molar surgery. A total of six anatomic sites on 10 patients who showed a topographic relationship between the apices of the third molar root and the mandibular canal were preoperatively assessed by five oral surgeons using conventional panoramic radiographs. These were complemented and compared with secondary reconstructed paraxial and panoramic volumetric computed tomography images. The position of the apices in relation to the mandibular canal could be revealed on $94 \%$ of volumetric computed tomography reconstructed paraxial images. In $90 \%$ of the para-axial images, it was possible to assess the relationship of the mandibular canal 
and its adjacent anatomy. However, the visual grading score for conventional panoramic images was significantly better on all seven assessed anatomic sites compared with the reconstructed volumetric computed tomography panoramic images.

These results suggest that the volumetric computed tomographic para-axial images may provide a significantly clearer perception of the mandibular nerve than conventional panoramic radiographs. However, CBVCT has a radiation dose of up to 10 times higher than the conventional panoramic radiograph. In this study it was concluded that the conventional panoramic radiographs were shown to be better than the volumetric computed tomography reconstructed panoramic images and were an invaluable tool in the "expert-derived" assessment and posed the potential for identifying the need for further volumetric computed tomography diagnostic procedures.

Enciso et al. (2006) examined the spatial relationship of six impacted third molars using imaging data obtained from various 3-D volumetric imaging systems (NewTom 9000, J. Morita 3D Accu-i-tomo and Hitachi MercuRay). An interactive virtual model of a proposed third molar surgical site, including the third molar and the inferior dental canal, was developed. They concluded that anatomical accuracy, benefit for risk assessment, and cost effectiveness of developing the model requires further investigation.

\section{Significant radiographic signs}

From the results of the previous authors mentioned above, a number of significant radiographic signs have been identified that act as markers for the relationship between the IAN and the third molar tooth root. (Table 3) 
$\underline{\text { TABLE } 3}$

Significant panoramic radiological signs found in previous studies

\begin{tabular}{|c|c|c|c|c|c|c|}
\hline \multirow[t]{2}{*}{ Parameter } & \multicolumn{6}{|c|}{ Study" } \\
\hline & $I$ & 2 & 3 & 4 & 5 & 6 \\
\hline $\begin{array}{l}\text { Third } \\
\text { molars } \\
\text { examined }\end{array}$ & 1117 & 25 & 300 & 73 & 202 & 423 \\
\hline $\begin{array}{l}\text { Radiograph } \\
\text { ic sign(s) }\end{array}$ & $\begin{array}{l}\text { 1.deflectio } \\
\text { n of molar } \\
\text { roots }\end{array}$ & $\begin{array}{l}\text { 1. } \\
\text { diversion } \\
\text { of canal } \\
2 . \\
\text { darkening } \\
\text { of root } \\
\mathbf{3 .} \\
\text { interruptio } \\
\text { n of } \\
\text { cortical } \\
\text { white } \\
\text { lines of } \\
\text { canal }\end{array}$ & $\begin{array}{l}\text { 1. darkening of } \\
\text { root } \\
\text { 2.interruption of } \\
\text { cortical white } \\
\text { lines of canal } \\
\text { 3. superimpositio } \\
\text { n of tooth over } \\
\text { canal } \\
\text { 4. combinations } \\
\text { all with } \\
\text { darkening of root } \\
\text { combined with } \\
\text { deflection of } \\
\text { root, narrowing } \\
\text { of root, } \\
\text { narrowing of } \\
\text { canal. }\end{array}$ & $\begin{array}{l}\text { 1. } \uparrow \\
\text { radiolucency } \\
\text { at apex of root } \\
\text { 2. narrowing } \\
\text { of canal } \\
\text { 3. interruption } \\
\text { of cortical } \\
\text { white lines of } \\
\text { canal. } \\
\text { 4. diversion of } \\
\text { canal } \\
\text { 5. presence of } \\
\text { two or more } \\
\text { markers }\end{array}$ & $\begin{array}{l}\text { Deviati } \\
\text { on of } \\
\text { canal }\end{array}$ & $\begin{array}{l}\text { 1. darkening of } \\
\text { root } \\
\text { 2.interruption } \\
\text { of the cortical } \\
\text { white lines of } \\
\text { canal } \\
\text { 3. diversion of } \\
\text { canal } \\
\text { 4. narrowing } \\
\text { of roots } \\
\text { 5. presence of } \\
\text { two or more } \\
\text { markers }\end{array}$ \\
\hline
\end{tabular}

* Study: (1) Valmaseda-Castellon E, Berini-Aytes L. (2001); (2) Blaeser B, et al., (2003); (3) Bell GW. (2004); (4) Monaco G, et al., (2004); (5) Mahasantipiya PM, et al., (2005); (6) Sedaghatfar M, et al., (2005)

Based on the results of these authors, our study will focus on the following six (6) radiographic signs that have been found to be statistically significant and clinically important in determining the relationship of the IAC with impacted molar teeth.in previous studies:

(1) Darkening of the root. This results from loss of root density in a tooth that is impinged upon by the canal. Normally the radiographic density of the root is uniform throughout its length and does not change when the tooth and the canal overlap (Figure 3). 


\section{FIGURE 3}

Darkening of the root of the mandibular third molar

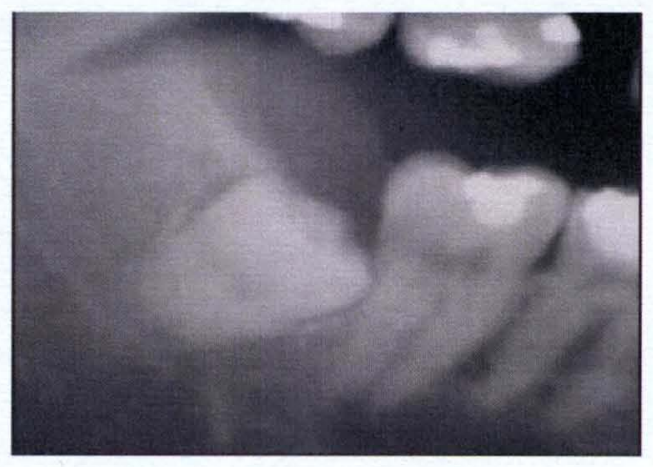

(2) Interruption of the cortical white lines of the mandibular canal. This is found when the radio-opaque lines that constitute the inferior alveolar canal are discontinuous because a tooth root lies within the canal. Disruptions to the continuity of the mandibular canal can be indicative of root proximity to the mandibular canal. Disruption may be defined as an interruption to the white, cortical boundaries of the canal, represented by the two radio-opaque lines that make up the roof and floor of the inferior alveolar canal. One or both lines may be involved and is considered to be interrupted if it disappears immediately before it reaches the tooth structure (Figure 4). 


\section{FIGURE 4}

Interruption of the cortical white lines of the mandibular canal

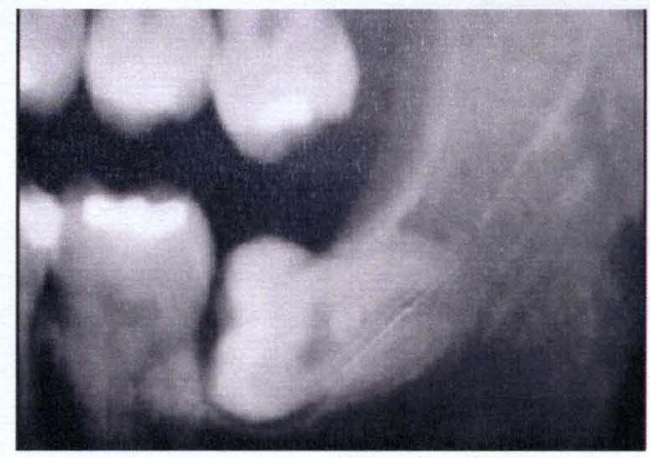

(3) diversion or displacement of the inferior alveolar canal. This occurs when there is a change in direction as the canal crosses the mandibular third molar. This sign presents as mandibular canal remodeling literally around the tooth (Figure 5).

\section{FIGURE 5}

Diversion or displacement of the inferior alveolar canal

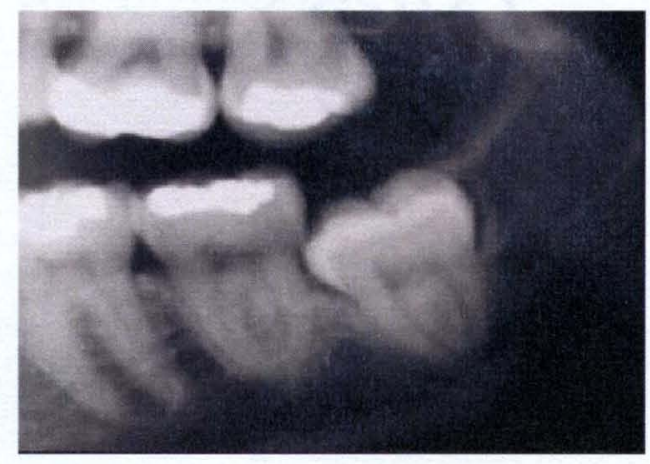

(4) Deflected roots. This refers to visible deflection of roots in the proximity of the mandibular canal. A close, proximal relationship of root to the mandibular 
canal may be seen as an abrupt deviation of the root as it encounters the inferior alveolar canal. The root itself may be deflected to the buccal or lingual, or the root may completely engulf the canal. When the apex of the roots are pointed mesially or distally the radiograph will display the apex of the root tips diverted in a mesial or distal direction such as the one shown. Roots deflected buccally or lingually may not be visualized radiographically due to the inability of the radiograph to image structures lying parallel to the imaging beam. (Figure 6)

\section{FIGURE 6}

Deflected roots of the mandibular third molar

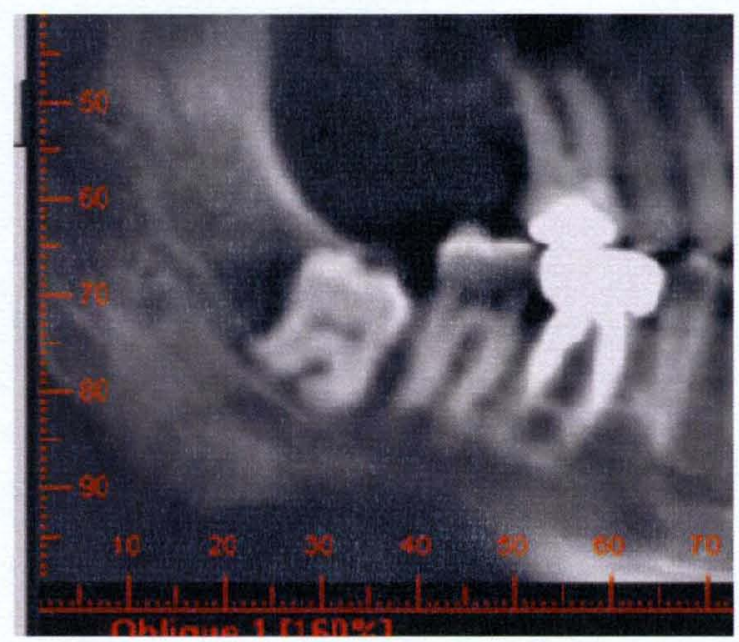

(5) Superimposition of the canal. This occurs when the superior and inferior cortical bone borders of the mandibular canal are superimposed on the root of the third molar. Even though superimposition of the canal to the roots of the third molar could be that one is buccal or lingual to one another, prior research has shown that this sign is viable to look for (Figure 7). 


\section{FIGURE 7}

Superimposition of the canal with the mandibular third molar

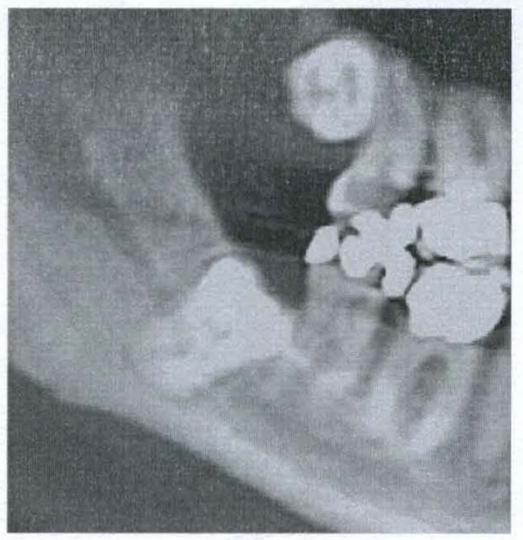

(6) Narrowing of the inferior alveolar canal. This refers to the constriction of the inferior alveolar canal and can be indicative of a close proximity of the nerve to the tooth. Narrowing of the canal is often associated with the downward displacement of the upper and lower borders of the mandibular canal, creating an hourglass appearance. The hourglass appearance may indicate a partial or complete encirclement of the canal by the root (Figure 8).

\section{FIGURE 8}

Narrowing of the inferior alveolar canal

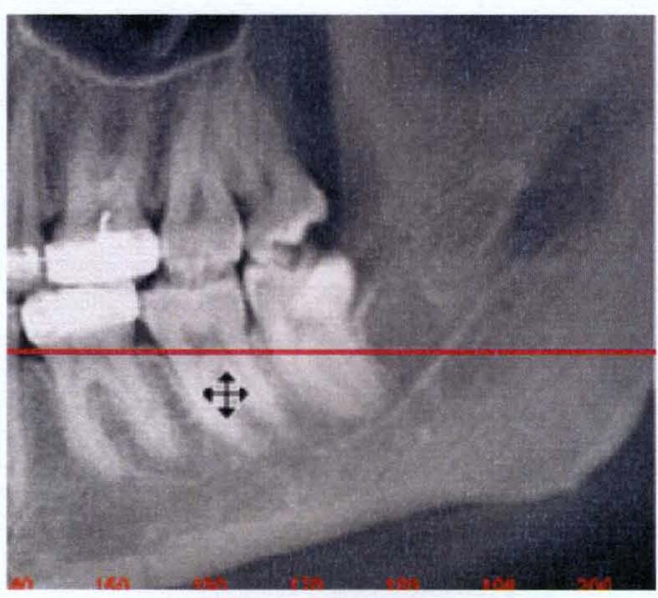


Previous investigations investigating the radiological signs associated with the relationship of the IAC to mandibular third molars have all been performed using conventional panoramic images with a set focal trough width and arch form. To date there is a dearth of information in the literature comparing the prevalence of these signs with panoramic images generated with different machines, each with a different focal trough width and arch form shape. Utilizing CBVCT, it is possible to compare these variables to determine if focal trough width and arch form shape play a factor in the visualization of high risk radiological signs for mandibular third molar and IAN involvement.

The panoramic radiograph was, until very recently the standard radiographic image made to analyze third molars prior to extraction (Smith et al., 1997). Such panoramic radiographs are used to determine the type of impaction. Also, they are used to observe if there is any presence or sign that the third molar has an association with the mandibular canal that would increase the likelihood of IAN injury if the third molar were removed. Panoramic radiographs are known to have a number of limitations, including but not limited to: magnification, distortion, and superimposition of structures (Tronje et al., 1981a; Tronje et al., 1981b; Tronje et al., 1981c). Conventional panoramic X-ray systems have a fixed movement pattern giving only one pre-selected layer that is designed to coincide with an 'average patient'. Deviation in size and form of an individual jaw from the pre-selected image layer will result in varying degrees of distortion and unsharpness inclusive of the third molar region (Welander et al., 1989). These radiographs may or may not produce radiographic signs a surgeon would look for 
when attempting to determine if an impacted mandibular third molar is intimately positioned to the IAN.

The purpose of this investigation is to determine if simulated panoramic radiographs viewed in two different focal trough shapes, and three different focal trough widths alter the ability of observers to identify high risk radiological signs associated with an intimate anatomic relationship between impacted third molar teeth and the mandibular canal. 


\section{CHAPTER II}

\section{PURPOSE AND HYPOTHESIS}

\section{Study Objectives}

The aim of this research was to simulate panoramic images of different focal trough specifications (trough size and arch shape) and relate previously reported high risk panoramic third molar radiographic signs associated with the mandibular canal to actual 3D distances determined by Cone Beam Volumetric Computerized Tomography (CBVCT). Reconstructed panoramic radiographs generated from cone beam volumetric computed tomography (CBVCT) datasets have been used in this study. All images were generated using an i-CAT ${ }^{\circledR}$ (Imaging Sciences International, Hatfield, PA). This study postulates that the wider the focal trough width and the more customized the focal trough shape to the patient's arch form, the more accurate will be the detection of high risk radiologic signs present in the reconstructed panoramic radiographs.

The specific aims were to:

1) Determine whether a generated customized focal trough shape compared to an average form of dentition focal trough shape more accurately indicates panoramic dental and osseous radiological signs indicative of high risk nerve association and features (e.g. darkening of 
the root, disruption of the cortical white lines of the IAN canal, deviation of the IAN canal, deflection of roots, superimposition of the roots on the IAN canal, narrowing of the IAN canal (Sedaghatfar et al. 2005; Bell et al. 2004; Mahasantipiya et al. 2005; Smith et al. 1997) for determining a relationship between impacted third molar teeth and the IAN canal.

2) Determine whether a relationship between panoramic radiography focal trough widths and panoramic dental and osseous high risk nerve association radiological signs and features (darkening of the root, disruption of the cortical white lines of the IAN canal, deviation of the IAN canal, deflection of roots, superimposition of the roots on the IAN canal, narrowing of the IAN canal), for determining a relationship between impacted third molar teeth and the IAN canal.

\section{Study Hypotheses}

\section{Null Hypotheses $\left(H_{o}\right)$}

1) There is no difference between focal customized and standardized trough shapes and high risk radiological signs associated with the IAN.

2) There is no difference between focal trough widths and high risk radiological signs associated with the IAN. 


\section{Alternate Hypotheses $\left(H_{I}\right)$}

1) There is a difference between customized and standardized focal trough shapes and high risk radiological signs associated with the IAN.

2) There is a difference between focal trough widths and high risk radiological signs associated with the IAN. 


\section{CHAPTER III}

\section{METHODS AND MATERIALS}

\section{Sample and Study Approval}

The Human Studies Committee of the University of Louisville approved the study protocol (HSC reference \# 585.05) through Expedited Review Procedure in November 2005.

\section{Sample}

The sample was derived from the database of cone beam CT image datasets, obtained using an FDA/CDRH approved cone beam volumetric computerized tomography scanner (i-CAT, Imaging Sciences International, Hatfield, PA, USA) located in Radiology and Imaging Sciences, Dept. of Surgical/Hospital Dentistry at the University of Louisville School of Dentistry. This instrument is partially owned and operated by Drs. Allan G. Farman and William C. Scarfe within the ULSD faculty private practice. A retrospective radiographic chart audit was performed by the PI between January and February 2005 on all available CBVCT scans (approximately 330 available at that time). The sample was not identified by age, gender, or ethnicity.

Only CBVCT datasets that were made using a full field of view CBVCT were considered for inclusion in the study. Patients are referred for imaging related principally 
to the assessment of pathology, temporomandibular joint evaluation and implant site assessment. At the time of the study, few patients had been specifically referred for third molar assessment related to LAN involvement. Therefore numerous imaging studies had been performed using various imaging protocols including field limitation and high and low resolution voxels.

The i-CAT unit was operated at 3-8 mA (pulse-mode) and $120 \mathrm{kV}$ using a high frequency generator with fixed anode and $0.5 \mathrm{~mm}$ nominal focal spot size. The anterior symphyseal region of the mandible of each patient was inserted into the chin holder and vertical and horizontal lasers were used to position the patient's head. The patient's head was also oriented by adjustment of the chin support until the mid-sagittal plane was perpendicular to the floor and the horizontal laser reference coincided with the intersection of the posterior maxillary teeth and alveolar ridge. Lateral scout radiographs were taken and small adjustments to head position were made so that discrepancies between bilateral structures (e.g. posterior and inferior borders of the mandibular rami and zygomatic arches) were less than $5 \mathrm{~mm}$. A single 360 degree rotation, 20 s. scan, comprising 306 basis projections was then made for each skull with a $17.0 \mathrm{~cm}$ (diameter) x $13.2 \mathrm{~cm}$ (height) field of view using i-CAT acquisition software (version 1.7.7). Exposure parameters were unable to be altered as acquisition was controlled by automatic exposure control. Primary reconstruction of the data was automatically performed immediately after acquisition and took approximately 60 seconds. Secondary reconstruction occurred in "real time" and provided contiguous color correlated perpendicular axial, sagittal, and coronal 2D MPR slices, with isotropic $0.4 \mathrm{~mm}$ voxels in each orthogonal plane. 
Previous studies have shown that there is no magnification or distortion in resultant secondary reconstruction images from this machine and all measurements can be assumed to have a 1:1 relationship with the actual object. Images were made according to the manufacturer's recommendations using the chin rest and vertical side guides, aligning the vertical light beam at the midline and the horizontal light beam intersecting the top of the right and left external auditory meatus. CBVCT images were acquired using a flat panel hydrogenated amorphous silicon detector.

The following inclusional criteria were applied to the available full FOV scans:

1) Mandibular third molar teeth had to be present in at least one side

2) Mandibular third molar teeth were within $3 \mathrm{~mm}$ from the inferior alveolar nerve canal (IAC).

After examining the scans, 50 mandibular third molars met the inclusion criteria. Most scans were excluded due to the absence of third molar teeth, third molars were not near the IAC, or the scan was a limited volume scan not including the desired anatomical details.

The datasets from the included scans were accessed by the PI and the dataset was viewed in all three planes: sagittal, coronal, and axial. (Figure 9) 


\section{FIGURE 9}

Conventional i-CAT three planes of view: axial, sagittal, and coronal

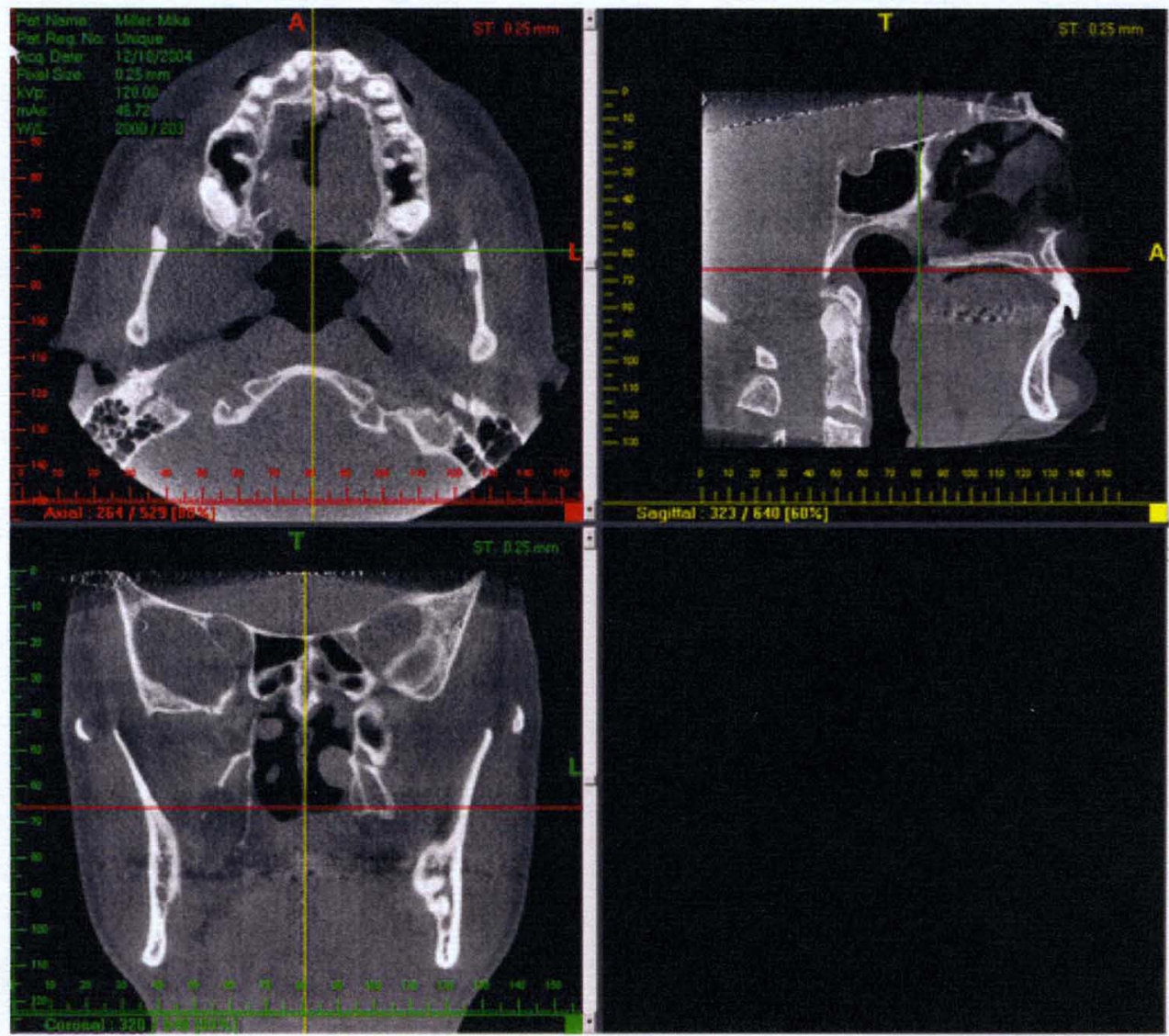

\section{Panoramic reconstruction}

\section{Customized focal trough}

Panoramic reconstruction utilizing CBVCT images was accomplished by first viewing the mandible in the axial view at the occlusal level of the third molars. No manipulation of the sagittal view was done before the axial view was examined to locate the focal plane of the focal trough. The CB devices default patient sagittal position was used. This 
accounts for the variability in head positioning that is possible when conventional panoramic radiographs are taken. The focal plane of the focal trough was then constructed by placing points throughout the occlusal surfaces of the teeth present in the axial view. These points were adjusted accordingly so that when the reconstructed panoramic focal trough was viewed at $.25 \mathrm{~mm}$ width, the mandibular canal was visible. This was done to verify the mandibular canal position was as close as possible to the focal plane for the clearest visibility of the IAN when the focal trough widths of 10,20 , and 40 were constructed. (Figure 10) Panoramic reconstruction was accomplished on the i-CAT to a scale of $1 \mathrm{~cm}=12 \mathrm{~mm}$. This was done to account for distortion and magnification that is typically encountered on a traditional panoramic radiograph. 


\section{FIGURE 10}

CBVCT display showing axial view with panoramic reconstruction and cross section view of mandible

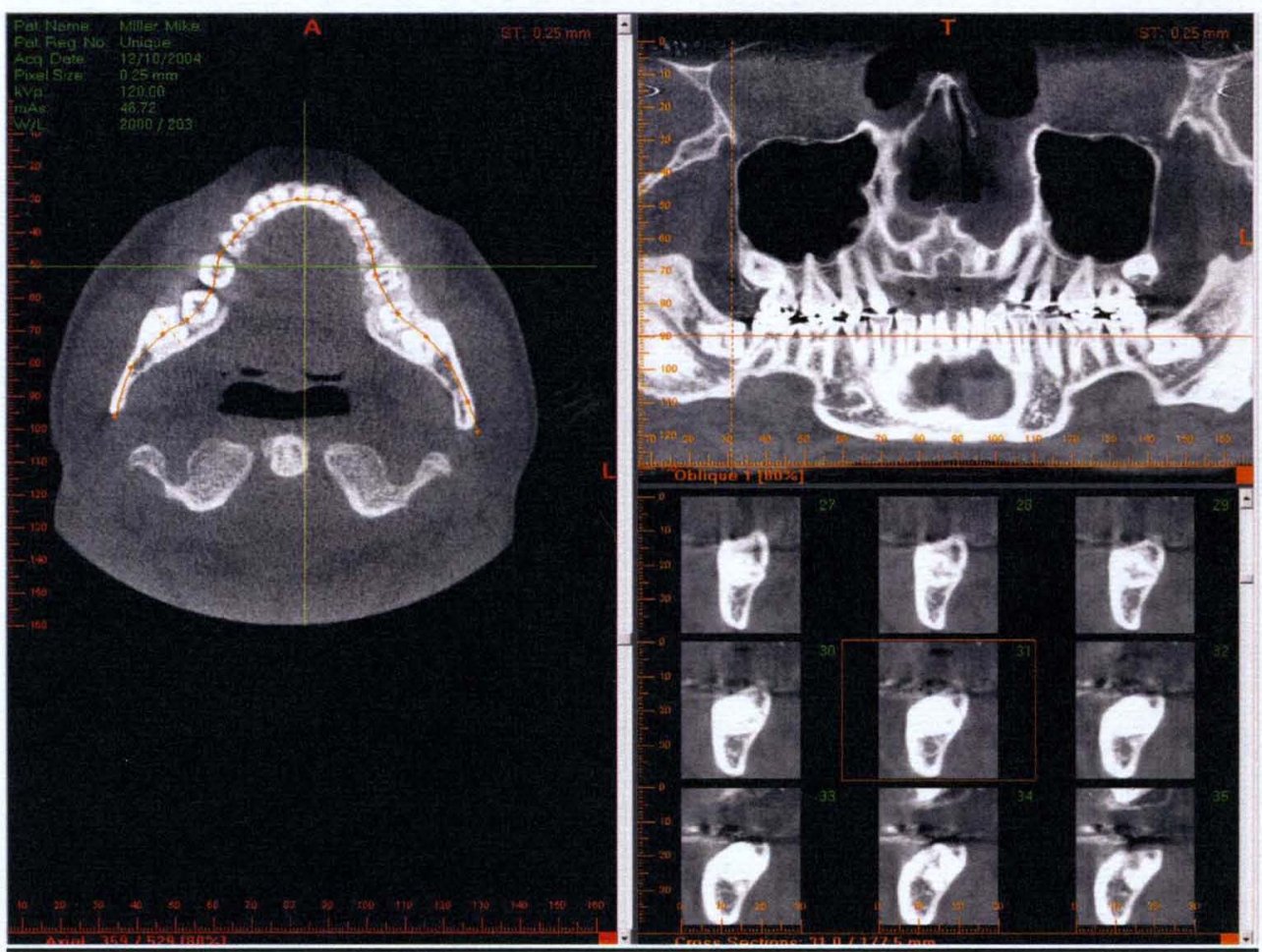

\section{Standardized Focal Trough}

The average form of dentition focal trough (Welander et al. 1989) was used to construct the average form dentition focal trough shape used in this study. No manipulation of the sagittal view was done before the axial view was examined to construct the focal plane of the focal trough. An acetate copy was made to scale of 1:1 from the standard form of the dentition and the mandible (Welander et al., 1989). (Figure 11) 


\section{FIGURE 11}

Average focal trough form Welander et al., 1989

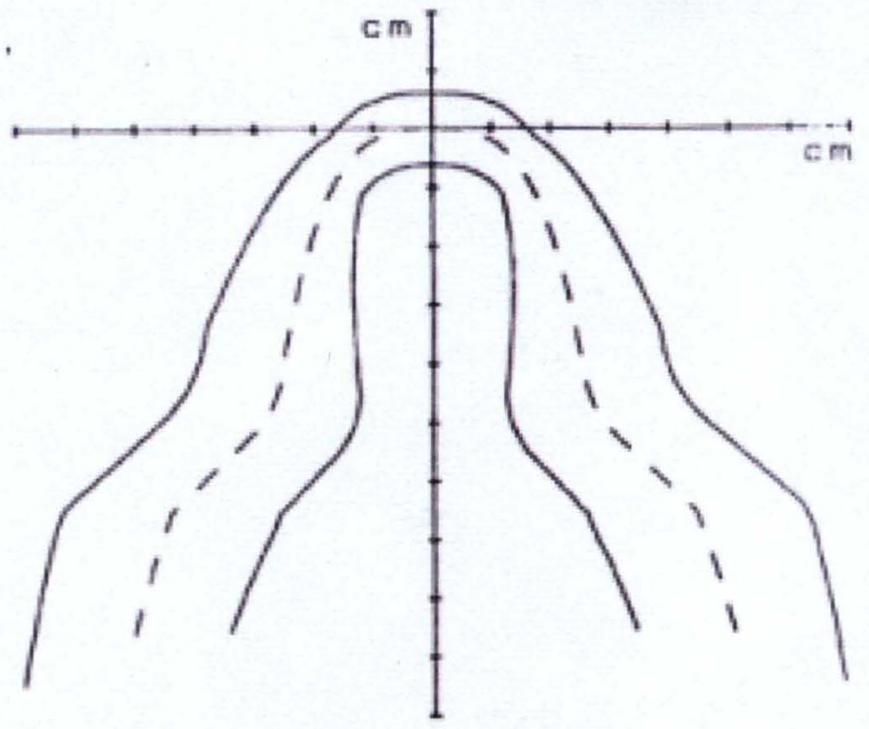

In the dataset axial view of the mandible, the acetate was taped on the computer screen so that the intersection of the horizontal and vertical reference lines was positioned between the mandibular central incisors (vertical line) and on the cingulum of the mandibular central incisors (horizontal line). (Figure 12) 


\section{FIGURE 12}

Acetate of average focal trough form (Welander et al., 1989) placed over mandible.

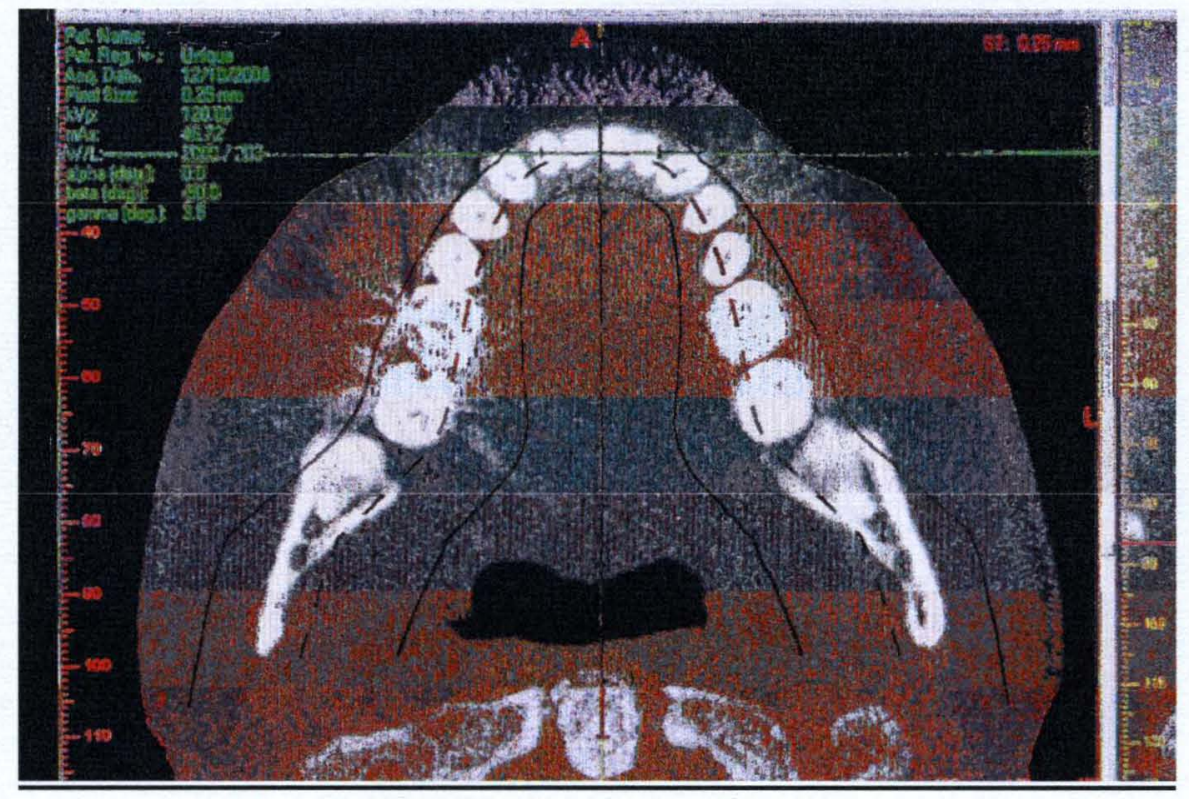

The focal plane of the focal trough was then constructed by placing points along the dashed line on the acetate. Panoramic reconstruction was accomplished on the i-CAT to a scale of $1 \mathrm{~cm}$ (acetate): $.96 \mathrm{~cm}$ on the iCAT. This was the closest to a true 1:1 relationship that could be accomplished.

\section{Third Molar Image Display}

Panoramic reconstructions were generated for both the customized focal plane and focal trough, and standardized arch form based on the average form of dentition of mandible in focal trough widths of 10,20 , and $40 \mathrm{~mm}$. This provided a total of three hundred third molars, fifty in each focal trough width group. The image of each third molar in each focal trough width was cropped approximately $3 \mathrm{~cm}$ in all directions. This was done so 
the raters could see nothing but the third molar and all close approximations present. Each cropped third molar was exported as a lossless TIF format without image enhancement. (Figure 13) For display and analysis, the cropped third molar images were imported to commercial photographic imaging software (Adobe Photoshop 7.0; 2002; Adobe, 2002; San Jose, CA) and images equalized prior to analysis. Equalization redistributes the brightness values of pixels so that they are more evenly represented over the entire range of brightness levels. After detecting the brightest and darkest values in the image, they are remapped so the brightest value represents white and the darkest represents black. Brightness is then equalized by distributing the intermediate pixel values evenly through the gray scale. This was done to better view the anatomical detail of the IAN and the mandibular third molar.

\section{FIGURE 13}

Representative example of cropped third molar image

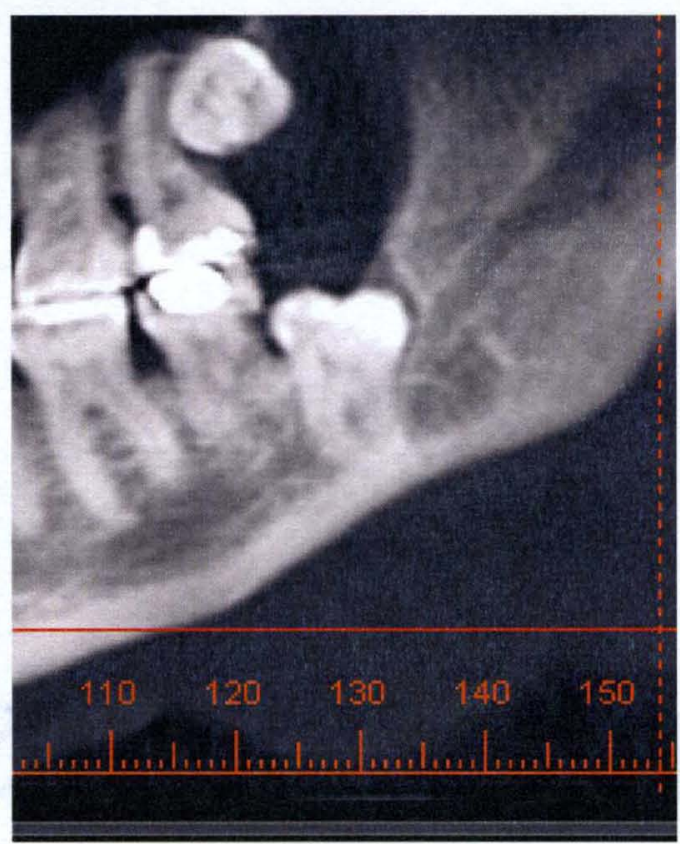


The 300 images were coded and all images were viewed on a 19 inch flat panel color active matrix TFT (Dell E171FPb Flat Panel Color Monitor, Dell inc., Round Rock, TX, USA) screen with a resolution of $1024 \times 768$ at $60 \mathrm{~Hz}$ and a 0.264 dot pitch, operated at 32 bit. The 300 images were imported into a slide show using commercial software $\operatorname{IrfanView} \odot$.

\section{Determination of Third Molar Relationship}

\section{Subjective Evaluation}

Two independent observers viewed images of the 300 molars. The PI randomized all images in regards to focal trough width and focal trough shape using Research Randomizer $\odot$ software. Guided by the published radiographic signs associated with IAC involvement with the roots of third molars (Valmaseda-Castellon and Berini-Aytes, 2001; Blaeser et al., 2003; Bell, 2004; Monaco et al., 2004; Mahasantipiya et al., 2005), each image was viewed and observers asked to indicate 1) Whether the image was of acceptable image quality and 2) which sign(s) of IAC involvement are present. Observers were provided with an instructional sheet providing examples of IAC associations to assist them in their decision (Table 4). 


\section{$\underline{\text { TABLE } 4}$}

Radiographic signs observed
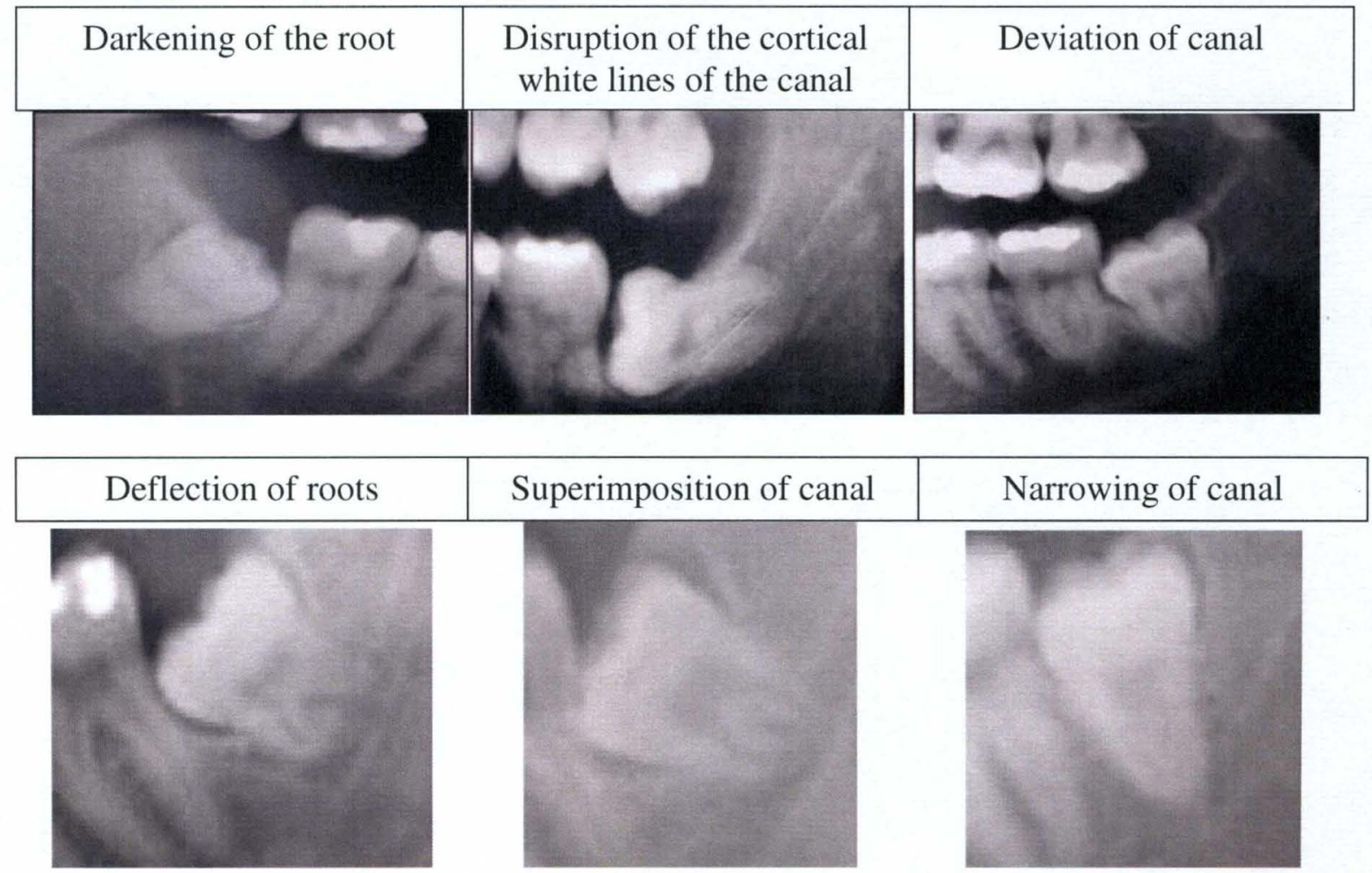

To minimize intra- and inter-observer variability, each observer viewed an additional 20 images selected at random (Research Randomizer@ software:

http://www.randomizer.org/) for each focal trough width $(10,20$, and $40 \mathrm{~mm})$ and each focal trough shape (standard and customized) for a total of 120 repeated images. 


\section{Objective Evaluation}

Utilizing the serial transplanar cross sectional image display mode (Figure 14), direct measurements from the end of the root of the molar to the IAC were performed by each observer. The dataset also was used to detect the canal position, and whether the root was notched or the canal transverses through the root. Repeated measurements of 20 of the total 50 were made to determine intra- and inter-observer variability. These 20 repeated tooth measurements were randomized using Research Randomizer@ software.

\section{FIGURE 14}

Screen image display demonstrating representative cross-sectional images of mandible to measure distance from root to IAN

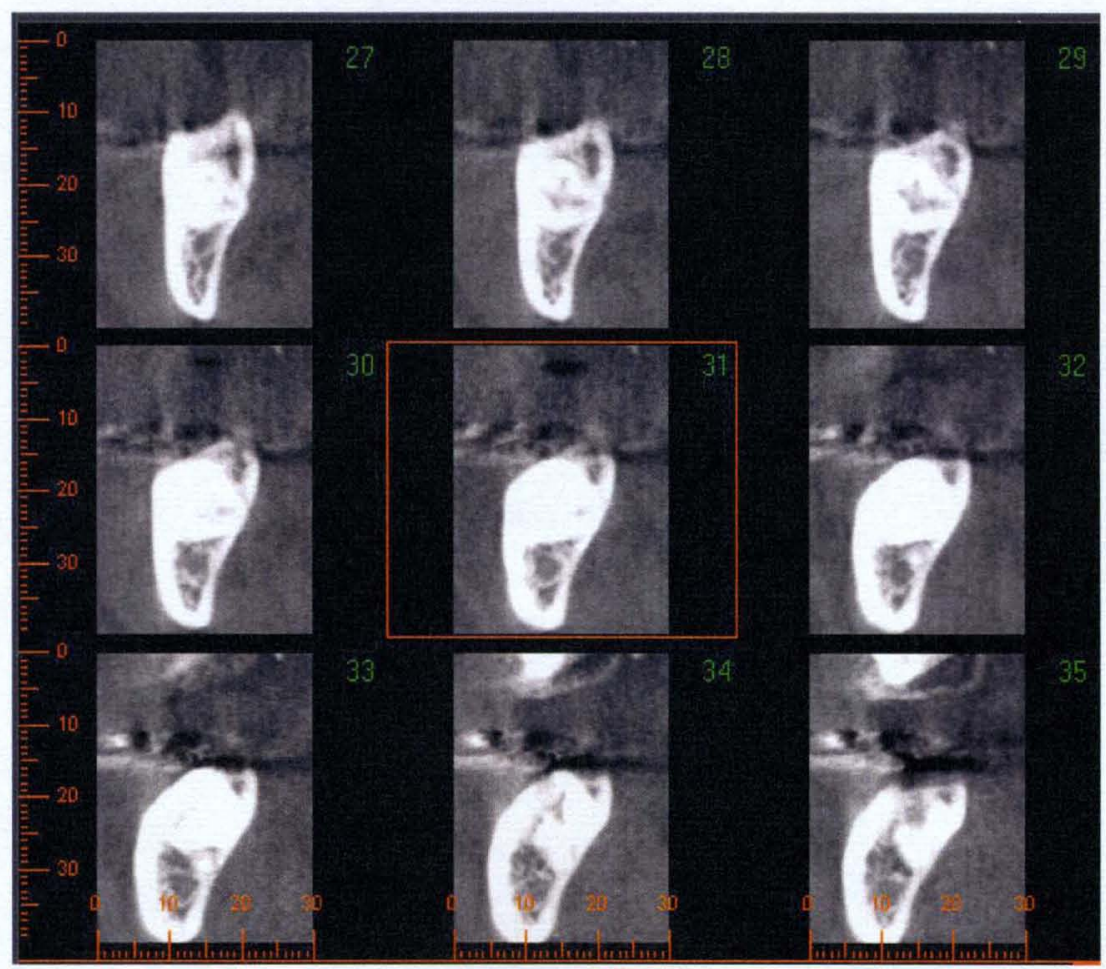




\section{Data Analysis}

All data was input into a spreadsheet (Microsoft Excel XP, Microsoft Corp., Redmond, WA, USA) and then exported to a statistical analysis program SAS (Statistical Analysis System Version 8; SAS Institute Inc., Cary, NC, 1999). Ordinal logistic regression analysis was used to measure the outcome of radiographic signs present with three categories (Category 1, 0 to $1 \mathrm{~mm}$; Category 2, $>1$ to $<2 \mathrm{~mm}$, Category $3,>2 \mathrm{~mm}$ ) and focal trough width. The Intraclass correlation coefficient (ICC) was used as a measure of agreement to measure both inter -and intra-rater variability. 


\section{CHAPTER IV}

\section{RESULTS}

Fifty images of mandibular third molar teeth were examined by each observer to provide a total of 100 observations. Images were presented representing three different focal trough widths $(10,20$, and $40 \mathrm{~mm})$ and two focal trough shapes (customized and average form). In addition, the observers measured the distance between the third molar root and the IAC, recorded the bucco-lingual relationship to the mandibular canal, and also the association of the IAC to root of the third molar.

Distances from the third molar root varied and could be classified into three groups. (Table 5)

\section{TABLE 5}

Distance from third molar root to IAC as measured on the transplanar cross-sectional images.

\begin{tabular}{lcc}
\hline Category & Frequency & Percent \\
\hline $0-1 \mathrm{~mm}$ & 78 & 78 \\
$1-2 \mathrm{~mm}$ & 10 & 10 \\
$2+\mathrm{mm}$ & 12 & 12 \\
\hline Total & 100 & 100 \\
\hline
\end{tabular}


The bucco-lingual relationship of the 100 mandibular third molar teeth to the mandibular canal based on imaging findings are shown in Table 6. There was variability in the relationships of the IAC to the root with most $(46 \%)$ being buccal to the root. Statistical analysis showed no significance in relative position of the IAC to the root of the tooth.

\section{TABLE 6}

Buccolingual position of the mandibular canal in relation to the third molar root.

\begin{tabular}{lcc}
\hline Location of IAC relative to mandibular third molar tooth & Frequency & Percent \\
\hline Buccal & 46 & 46 \\
Lingual & 23 & 23 \\
Central & 31 & 31 \\
\hline Total & 100 & 100 \\
\hline
\end{tabular}

The incidence of radiographic signs observed related to the association of the IAC to the root of the third molar is shown in Table 7. Several teeth showed notching of the root with the nerve, while a majority showed nothing present. No canals were observed to travel through the middle of the roots. 


\section{TABLE 7}

Incidence of radiographic signs of IAC involvement in relation to the root of the third molar

\begin{tabular}{lcc}
\hline Radiographic Sign & Frequency & Percent \\
\hline Root is notched & 21 & 21 \\
Nothing & 79 & 79 \\
Nerve runs through root & 0 & 0 \\
\hline Total & 100 & 100 \\
\hline
\end{tabular}

Frequencies of the six panoramic radiographic signs associated with IAC involvement with the root of the mandibular third molar features with respect to focal trough width and focal trough shape are shown in Table 8 and 9 respectively/

\section{TABLE 8}

Customized arch form- signs present

\begin{tabular}{lccc}
\hline & \multicolumn{3}{c}{ Focal Trough Width (mm) } \\
\cline { 2 - 4 } Radiographic Sign & $\mathbf{1 0} \mathbf{m m}$ & $\mathbf{2 0} \mathbf{m m}$ & $\mathbf{4 0 m \boldsymbol { m }}$ \\
\hline Darkening of root & 62 & 54 & 42 \\
Disruption of cortical & 49 & 45 & 38 \\
lines & 12 & 7 & 10 \\
Deviation of canal & 26 & 17 & 14 \\
Deflection of roots & 54 & 48 & 45 \\
Superimposition of & 24 & 16 & 17 \\
canal & 2 & 2 & 7 \\
Narrowing of canal & & & \\
Undiagnostic & & & \\
\hline
\end{tabular}




\section{TABLE 9}

Average form arch form- signs present

\begin{tabular}{lccc}
\hline & \multicolumn{3}{c}{ Focal Trough Width $(\mathbf{m m})$} \\
\cline { 2 - 4 } Radiographic Sign & $\mathbf{1 0 \mathbf { m }}$ & $\mathbf{2 0 \mathbf { m m }}$ & $\mathbf{4 0} \mathbf{m m}$ \\
\hline Darkening of root & 19 & 32 & 26 \\
Disruption of cortical & 16 & 34 & 34 \\
lines & & & \\
Deviation of canal & 6 & 13 & 7 \\
Deflection of roots & 4 & 13 & 14 \\
Superimposition of & 15 & 38 & 28 \\
canal & 8 & 14 & 7 \\
Narrowing of canal & 60 & 28 & 29 \\
Undiagnostic & & & \\
\hline
\end{tabular}

Multivariate analysis using these 6 radiographic signs as predictor variables relative to the focal trough width and focal trough shape showed that two features, 1) darkening of the root and 2) narrowing of the canal in focal trough width $20 \mathrm{~mm}$ and the customized arch form was a significant predictor of close involvement of the root of the tooth to the mandibular nerve (Table 10).

\section{TABLE 10}

Type III Analysis of Effects - Trough width $20 \mathrm{~mm}$, customized arch form

\begin{tabular}{llll}
\hline Effect & DF & Wald chi-square & P value \\
\hline Darkening of root & 2 & 6.8825 & $\mathbf{. 0 3 2 0}$ \\
Disruption of cortical lines & 1 & 1.0038 & .3164 \\
Deviation of canal & 1 & 0.0000 & .9978 \\
Deflection of roots & 1 & 2.2848 & .1306 \\
Superimposition of canal & 1 & 1.2240 & .2686 \\
Narrowing of canal & 1 & 3.9473 & $\mathbf{. 0 4 6 9}$ \\
\hline
\end{tabular}


Tables $11-16$ show the inter-rater agreement as determined by the average measures ICC varied for each of the six panoramic signs present.

For darkening of the root, there was only significance in two focal trough widths (10 and $20 \mathrm{~mm}$ ) with the average focal trough form (Table 11 ).

\section{TABLE 11}

ICC and ANOVA results comparing inter-rater agreement for each arch form and width

\begin{tabular}{llllll}
\hline \multicolumn{2}{l}{ Focal Trough Variable } & & \multicolumn{2}{c}{ F Test } \\
\cline { 1 - 1 } \cline { 5 - 6 } Arch Form & Trough Width & ICC & Value & Significance \\
\hline Customized & 10 & .457 & 1.840 & .096 \\
Customized & 20 & .378 & 1.608 & .155 \\
Customized & 40 & .061 & 1.065 & .446 \\
Average & 10 & .858 & 7.043 & .000 \\
Average & 20 & .608 & 2.550 & .024 \\
Average & 40 & .482 & 1.929 & .081 \\
\hline
\end{tabular}

For disruption of the cortical white lines of the canal, significance was found with observation in everything. (Table 12)

\section{TABLE 12}

\begin{tabular}{llllll}
\hline \multicolumn{2}{l}{ Focal Trough Variable } & & \multicolumn{2}{c}{ F Test } \\
\cline { 1 - 1 } \cline { 5 - 6 } Arch Form & Trough Width & ICC & Value & Significance \\
\hline Customized & 10 & .640 & 2.778 & .016 \\
Customized & 20 & .711 & 3.462 & .005 \\
Customized & 40 & .588 & 2.425 & .030 \\
Average & 10 & .965 & 28.500 & .000 \\
Average & 20 & .785 & 4.649 & .001 \\
Average & 40 & .602 & 2.513 & .026 \\
\hline
\end{tabular}


For deviation of the canal, there was only significance in three focal trough widths $(10,20$, and $40 \mathrm{~mm})$ all in the average focal trough form (Table 13).

\section{$\underline{\text { TABLE } 13}$}

\begin{tabular}{|c|c|c|c|c|}
\hline \multicolumn{2}{|c|}{ Focal Trough Variable } & \multirow[b]{2}{*}{ ICC } & \multicolumn{2}{|c|}{ F Test } \\
\hline Arch Form & Trough Width & & Value & Significance \\
\hline Customized & 10 & .387 & 1.632 & .147 \\
\hline Customized & 20 & -.115 & .897 & .593 \\
\hline Customized & 40 & .443 & 1.797 & .105 \\
\hline Average & 10 & .847 & 6.542 & .000 \\
\hline Average & 20 & .717 & 3.533 & .004 \\
\hline Average & 40 & .576 & 2.358 & .034 \\
\hline
\end{tabular}

For deflection of roots, there were only two significant measures and they were in the focal trough width of 10 and $20 \mathrm{~mm}$ in the average form (Table 14).

\section{TABLE 14}

\begin{tabular}{|c|c|c|c|c|}
\hline \multicolumn{2}{|c|}{ Focal Trough Variable } & \multirow[b]{2}{*}{ ICC } & \multicolumn{2}{|r|}{ F Test } \\
\hline Arch Form & Trough Width & & Value & Significance \\
\hline Customized & 10 & .000 & 1.00 & .500 \\
\hline Customized & 20 & -.353 & .739 & .742 \\
\hline Customized & 40 & .497 & 1.98 & .072 \\
\hline Average & 10 & .894 & 9.460 & .000 \\
\hline Average & 20 & .648 & 2.842 & .014 \\
\hline Average & 40 & .276 & 1.381 & .244 \\
\hline
\end{tabular}

For superimposition of canal, significance was found with observation in everything. (Table 15) 


\section{$\underline{\text { TABLE } 15}$}

\begin{tabular}{|c|c|c|c|c|}
\hline \multicolumn{2}{|c|}{ Focal Trough Variable } & \multirow[b]{2}{*}{$I C C$} & \multicolumn{2}{|c|}{ F Test } \\
\hline Arch Form & Trough Width & & Value & Significance \\
\hline Customized & 10 & .700 & 3.333 & .006 \\
\hline Customized & 20 & .580 & 2.381 & .033 \\
\hline Customized & 40 & .550 & 2.220 & .045 \\
\hline Average & 10 & .968 & 31.667 & .000 \\
\hline Average & 20 & .587 & 2.421 & .031 \\
\hline Average & 40 & .560 & 2.274 & .041 \\
\hline
\end{tabular}

For narrowing of the canal, significance was only found in two of the measurements. The customized arch form $40 \mathrm{~mm}$ focal trough width, and the average arch form in the $10 \mathrm{~mm}$ focal trough width. (Table 16)

\section{TABLE 16}

\begin{tabular}{llllll}
\hline \multicolumn{2}{l}{ Focal Trough Variable } & & \multicolumn{2}{c}{ F Test } \\
\cline { 1 - 1 } \cline { 5 - 6 } Arch Form & Trough Width & ICC & & Value & Significance \\
\hline Customized & 10 & -.667 & .600 & .863 \\
Customized & 20 & -.600 & .625 & .843 \\
Customized & 40 & .581 & 2.389 & .033 \\
Average & 10 & .913 & 11.435 & .000 \\
Average & 20 & .510 & 2.042 & .064 \\
Average & 40 & .485 & 1.943 & .078 \\
\hline
\end{tabular}

Inter-observer agreement in the measurement of root to nerve and nerve position was found to be statistically significant $(\mathrm{P}<.05)$. (Table 17) 


\section{TABLE 17}

ICC and ANOVA results comparing measurements of root to nerve, nerve position, and nerve to root association.

\begin{tabular}{lccc}
\hline \multirow{2}{*}{ Measurement variable } & & \multicolumn{2}{c}{ F Test } \\
\cline { 3 - 4 } & ICC & Value & Significance \\
\hline distance measurement & .635 & 2.737 & .015 \\
nerve position & .640 & 2.776 & .014 \\
nerve to root assoc. & .504 & 2.018 & .064
\end{tabular}

Tables 18-29 show the intra-rater agreement as determined by the average measures ICC varied for each of the six panoramic signs present.

For darkening of the root, Observer \#1 showed significance for every sign measurement (Table 17), whereas Observer \#2 showed significance in focal trough width $10 \mathrm{~mm}$-customized focal trough arch form and $10 \mathrm{~mm}$-average focal trough arch form (Table 18). 


\section{TABLE 18}

Intra-rater ANOVA Comparison of ICC for Observer \#1 for Observations concerning darkening of the root.

\begin{tabular}{lccccc}
\hline \multirow{2}{*}{ Focal Trough Variable } & & \multicolumn{2}{c}{ F Test } \\
\cline { 1 - 2 } \cline { 5 - 5 } Arch Form & \multirow{2}{*}{ Trough Width } & ICC & & Value & Significance \\
\hline Customized & 10 & .883 & 8.526 & .000 \\
Customized & 20 & .608 & 2.549 & .022 \\
Customized & 40 & .534 & 2.144 & .049 \\
Average & 10 & .879 & 8.263 & .000 \\
Average & 20 & .835 & 6.079 & .000 \\
Average & 40 & .653 & 2.882 & .012 \\
\hline
\end{tabular}

\section{TABLE 19}

Observer \#2- darkening of the root

\begin{tabular}{lcrrrr}
\hline \multirow{2}{*}{ Focal Trough Variable } & & \multicolumn{2}{c}{ F Test } \\
\cline { 1 - 1 } \cline { 5 - 6 } Arch Form & \multirow{2}{*}{ Trough Width } & ICC & Value & Significance \\
\hline Customized & 10 & .635 & 2.737 & .015 \\
Customized & 20 & -.462 & .684 & .794 \\
Customized & 40 & .406 & 1.684 & .128 \\
Average & 10 & .859 & 7.105 & .000 \\
Average & 20 & .293 & 1.415 & .224 \\
Average & 40 & -.153 & .867 & .620 \\
\hline
\end{tabular}


For disruption of the cortical while lines of the canal, Observer \#1 showed significance of great consistency in all measurements (Table 19) while Observer \#2 showed significant results with all but the $40 \mathrm{~mm}$ focal trough width in the average focal trough arch form. (Table 20)

\section{TABLE 20}

Intra-rater ANOVA Comparison of ICC for Observer \#1 for Observations concerning disruption of the cortical white lines of the canal.

\begin{tabular}{lcrrrr}
\hline \multicolumn{2}{l}{ Focal Trough Variable } & & \multicolumn{2}{c}{ F Test } \\
\cline { 1 - 1 } \cline { 5 - 6 } Arch Form & Trough Width & ICC & & Value & Significance \\
& & & & \\
\hline Customized & 10 & .533 & 2.140 & .050 \\
Customized & 20 & .744 & 3.905 & .002 \\
Customized & 40 & .727 & 3.663 & .003 \\
Average & 10 & .903 & 10.316 & .000 \\
Average & 20 & .732 & 3.727 & .003 \\
Average & 40 & .662 & 2.957 & .010 \\
\hline
\end{tabular}

\section{TABLE 21}

Observer \#2- disruption of the cortical white lines of the canal

\begin{tabular}{lcrrrr}
\hline \multicolumn{2}{l}{ Focal Trough Variable } & & \multicolumn{2}{c}{ F Test } \\
\cline { 1 - 1 } \cline { 5 - 6 } Arch Form & Trough Width & & ICC & Value & Significance \\
\cline { 1 - 1 } Customized & 10 & .566 & 2.305 & .036 \\
Customized & 20 & .533 & 2.140 & .050 \\
Customized & 40 & .543 & 2.188 & .045 \\
Average & 10 & .964 & 27.895 & .000 \\
Average & 20 & .705 & 3.389 & .005 \\
Average & 40 & .513 & 2.053 & .059 \\
\hline
\end{tabular}


For deviation of the canal, Observer \#1 showed significance in all measures except 10 and $20 \mathrm{~mm}$ focal trough width in the customized arch form (Table 21). However Observer \#2 showed only significant results in the 10 and $20 \mathrm{~mm}$ focal trough width in the average focal trough form. (Table 22)

\section{TABLE 22}

Intra-rater ANOVA Comparison of ICC for Observer \#1 for Observations concerning deviation of the canal.

\begin{tabular}{lcrrrr}
\hline \multicolumn{2}{l}{ Focal Trough Variable } & & \multicolumn{2}{c}{ F Test } \\
\cline { 1 - 1 } \cline { 5 - 5 } Arch Form & Trough Width & ICC & Value & Significance \\
\cline { 5 - 6 } Customized & 10 & -.188 & .842 & .644 \\
Customized & 20 & .472 & 1.895 & .082 \\
Customized & 40 & .717 & 3.536 & .004 \\
Average & 10 & .930 & 14.263 & .000 \\
Average & 20 & .695 & 3.283 & .006 \\
Average & 40 & .875 & 8.000 & .000 \\
\hline
\end{tabular}

\section{TABLE 23}

Observer \#2- deviation of the canal

\begin{tabular}{lcrrrr}
\hline \multicolumn{2}{l}{ Focal Trough Variable } & & \multicolumn{2}{c}{ F Test } \\
\cline { 1 - 1 } \cline { 5 - 5 } Arch Form & Trough Width & \multirow{2}{*}{ ICC } & Value & Significance \\
\cline { 5 - 6 } Customized & 10 & .469 & 1.884 & .084 \\
Customized & 20 & -.056 & .947 & .545 \\
Customized & 40 & -.157 & .865 & .623 \\
Average & 10 & .986 & 71.316 & .000 \\
Average & 20 & .773 & 4.400 & .001 \\
Average & 40 & .320 & 1.472 & .199 \\
\hline
\end{tabular}


For deflection of roots, Observer \#1 had significance in all measurements. (Table 23) whereas Observer \#2 had significance in only two measurements, 10 and $20 \mathrm{~mm}$ in the average focal trough form. (Table 24)

\section{$\underline{\text { TABLE } 24}$}

Intra-rater ANOVA Comparison of ICC for Observer \#1 for Observations concerning deflection of roots.

\begin{tabular}{lccccc}
\hline \multicolumn{1}{l}{ Focal Trough Variable } & & \multicolumn{2}{c}{ F Test } \\
\cline { 1 - 1 } \cline { 5 - 5 } Arch Form & Trough Width & ICC & Value & Significance \\
\cline { 5 - 6 } Customized & 10 & .000 & 1.000 & .050 \\
Customized & 20 & .000 & 1.000 & .050 \\
Customized & 40 & .667 & 3.000 & .009 \\
Average & 10 & .950 & 19.947 & .000 \\
Average & 20 & .712 & 3.478 & .004 \\
Average & 40 & .732 & 3.737 & .003 \\
\hline
\end{tabular}

\section{TABLE 25}

Observer \#2- deflection of roots

\begin{tabular}{lcrrrr}
\hline \multicolumn{2}{l}{ Focal Trough Variable } & & \multicolumn{2}{c}{ F Test } \\
\cline { 1 - 1 } \cline { 5 - 6 } Arch Form & Trough Width & \multirow{2}{*}{ ICC } & Value & Significance \\
& & & & \\
\hline Customized & 10 & .470 & 1.887 & .084 \\
Customized & 20 & .367 & 1.579 & .159 \\
Customized & 40 & .034 & 1.035 & .468 \\
Average & 10 & .985 & 65.842 & .000 \\
Average & 20 & .795 & 4.883 & .000 \\
Average & 40 & .259 & 1.349 & .256 \\
\hline
\end{tabular}


For superimposition of the canal Observer \#1 had significance in all measurements except the 20 and 40mm focal trough width in the customized arch form (Table 25). Observer \#2 had significance in only two measurements, 10 and $20 \mathrm{~mm}$ in the average focal trough form. (Table 26)

\section{TABLE 26}

Intra-rater ANOVA Comparison of ICC for Observer \#1 for Observations concerning superimposition of the canal.

\begin{tabular}{lccccc}
\hline \multicolumn{2}{l}{ Focal Trough Variable } & & \multicolumn{2}{c}{ F Test } \\
\cline { 1 - 1 } \cline { 5 - 5 } Arch Form & Trough Width & \multirow{2}{*}{ ICC } & & Value & Significance \\
\cline { 5 - 6 } Customized & 10 & .682 & 3.147 & .007 \\
Customized & 20 & .412 & 1.702 & .123 \\
Customized & 40 & .401 & 1.669 & .132 \\
Average & 10 & .931 & 14.474 & .000 \\
Average & 20 & .835 & 6.079 & .000 \\
Average & 40 & .606 & 2.536 & .023 \\
\hline
\end{tabular}

\section{TABLE 27}

Observer \#2- superimposition of the canal

\begin{tabular}{lccccc}
\hline \multicolumn{2}{l}{ Focal Trough Variable } & & \multicolumn{2}{c}{ F Test } \\
\cline { 1 - 1 } \cline { 5 - 5 } Arch Form & Trough Width & \multirow{2}{*}{ ICC } & Value & Significance \\
\cline { 5 - 6 } Customized & 10 & .162 & 1.193 & .349 \\
Customized & 20 & -.583 & .632 & .839 \\
Customized & 40 & .120 & 1.137 & .388 \\
Average & 10 & .883 & 8.537 & .000 \\
Average & 20 & .701 & 3.339 & .005 \\
Average & 40 & .223 & 1.287 & .290 \\
\hline
\end{tabular}


For narrowing of the canal, Observer \#1 had significance in all of the measurements (Table 27). Observer \#2 had significance in only two measurements, 10 and $20 \mathrm{~mm}$ in the average focal trough form. (Table 28)

\section{TABLE 28}

Intra-rater ANOVA Comparison of ICC for Observer \#1 for Observations concerning narrowing of the canal.

\begin{tabular}{lcrrrc}
\hline \multicolumn{2}{l}{ Focal Trough Variable } & & \multicolumn{2}{c}{ F Test } \\
\cline { 1 - 1 } \cline { 5 - 5 } Arch Form & Trough Width & \multirow{2}{*}{ ICC } & Value & Significance \\
\cline { 5 - 6 } Customized & 10 & .568 & 2.316 & .035 \\
Customized & 20 & .615 & 2.596 & .020 \\
Customized & 40 & .676 & 3.088 & .008 \\
Average & 10 & .911 & 11.263 & .000 \\
Average & 20 & .778 & 4.505 & .001 \\
Average & 40 & .645 & 2.819 & .013 \\
\hline
\end{tabular}

\section{TABLE 29}

Observer \#2- narrowing of the canal

\begin{tabular}{lcrrrr}
\hline \multicolumn{2}{l}{ Focal Trough Variable } & & \multicolumn{2}{c}{ F Test } \\
\cline { 1 - 1 } \cline { 5 - 5 } Arch Form & Trough Width & \multirow{2}{*}{ ICC } & Value & Significance \\
\cline { 5 - 6 } Customized & 10 & .469 & 1.884 & .084 \\
Customized & 20 & -.267 & .789 & .695 \\
Customized & 40 & .222 & 1.286 & .291 \\
Average & 10 & .950 & 19.947 & .000 \\
Average & 20 & .799 & 4.977 & .000 \\
Average & 40 & .367 & 1.579 & .159 \\
\hline
\end{tabular}


Intra-observer agreement between root to nerve measurement, nerve position, and nerve to root association showed significance $(\mathrm{P}<.05)$ in all of them in both observer \#1 and observer \#2. (Tables 30 \& 31)

\section{$\underline{\text { TABLE } 30}$}

Intra-rater ANOVA Comparison of ICC for Observer \#1 for measurements concerning root to nerve measurement, nerve position, and nerve to root association.

\begin{tabular}{lccc}
\hline \multirow{2}{*}{ Measurement variable } & & \multicolumn{2}{c}{ F Test } \\
\cline { 3 - 4 } & ICC & Value & Significance \\
\hline distance measurement & .614 & 2.593 & .020 \\
nerve position & .779 & 4.526 & .001 \\
nerve to root assoc. & .791 & 4.789 & .001
\end{tabular}

\section{TABLE 31}

Observer \#2- root to nerve measurement, nerve position, and nerve to root association.

\begin{tabular}{lccc}
\hline \multirow{2}{*}{ Measurement variable } & & \multicolumn{2}{c}{ F Test } \\
\cline { 3 - 4 } & ICC & Value & Significance \\
\hline distance measurement & .927 & 13.632 & .000 \\
nerve position & .972 & 35.526 & .000 \\
nerve to root assoc. & 1.00 & & .000
\end{tabular}




\section{CHAPTER V}

\section{DISCUSSION}

Radiological evaluation is essential in evaluating the topographic relationship between the mandibular canal and the mandibular third molar, and panoramic images are commonly used for this. Panoramic images lack the ability to provide spatial information, and numerous clinical studies have been performed to evaluate panoramic radiographic signs suggestive of communication with the inferior alveolar nerve.

(Valmaseda-Castellon and Berini-Aytes, 2001; Blaeser et al., 2000; Bell 2004; Monaco et al., 2004; Mahasantipiya et al., 2005; Sedaghatfar et al., 2005). The results of these authors indicate that each of the following either individually or in combination may act as a radiographic marker indicate a close relationship between the mandibular canal and the third molar: deflection of roots, diversion of canal, interruption of canal wall, darkening of root, superimposition of canal, narrowing of canal, narrowing of roots.

Bell (2004) examined panoramic images of 300 mandibular third molar teeth and reported that darkening of the root, interruption of cortical white lines of canal, and superimposition of tooth over canal significantly correlated third molar root and nerve communication. He also concluded that sensitivity and specificity of panoramic images in determining communication between the mandibular canal and the root of the third molar being $66 \%$ and $74 \%$ respectively is disappointing. He found that sensitivity and specificity vary widely among different observers. No previous studies have investigated 
the effect of varying focal trough shape and width on panoramic radiologic signs associated with proximity of the IAC to the third molar root. This study showed that two panoramic features, darkening of the root, and narrowing of the canal in the customized $20 \mathrm{~mm}$ focal trough shape and width all significantly correlated with very close proximity of mandibular third molar root to IAN. Two representative cases are shown in Figs. 15 and 16. These two features are consistent with those reported by Monaco et al., (2004). Darkening of the roots, found to be of significance in this study, has also been reported by other authors. (Blaeser et al., 2003; Bell, 2004; Monaco et al., 2004; Sedaghatfar et al., 2005).
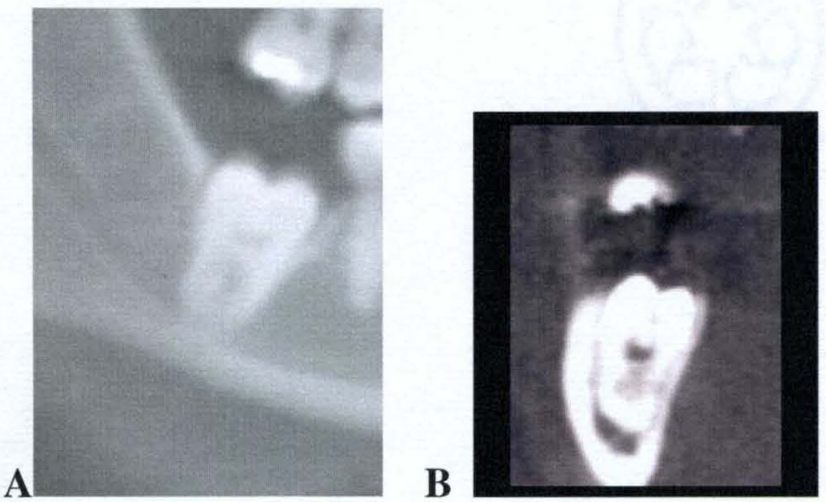

\section{FIGURE 15}

(A) Darkening of the root viewed on customized focal trough shape in $20 \mathrm{~mm}$ focal trough width. (B) Root of third molar communicating with IAN.

\section{FIGURE 16}

(A) Narrowing of the canal viewed on customized focal trough shape in $20 \mathrm{~mm}$ focal trough width. (B) Root of third molar communicating with IAN. 

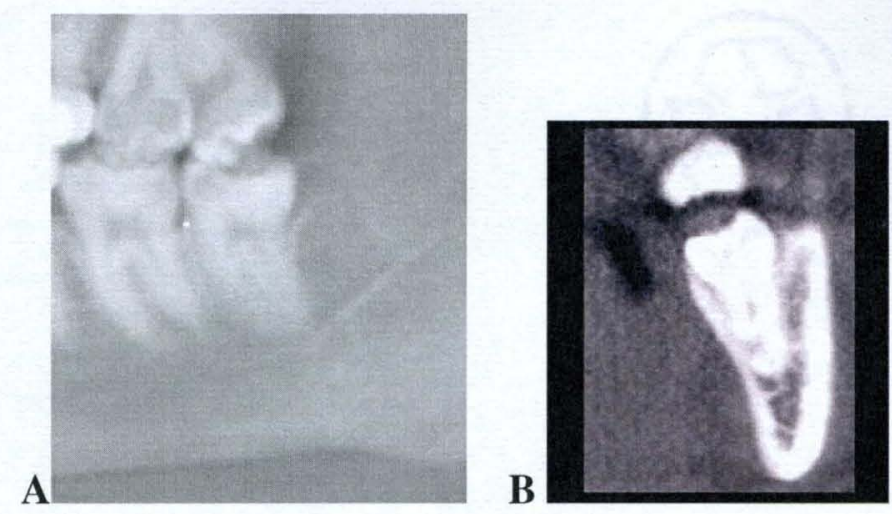

Because of the ability of CBVCT imaging to adjust the features of curved planar MPR, we were able to adjust both the focal tough shape and width of the constructed "panoramic" image. We found that that the customized focal trough shape and $20 \mathrm{~mm}$ focal trough width showed statistical significance for two signs. The resolution of a normal panoramic throughout the focal trough is not uniform, being $1.5 \mathrm{lp} / \mathrm{mm}$ at the periphery of the focal trough and increasing up to $5 \mathrm{lp} / \mathrm{mm}$ at the center of the focal trough. (Scarfe et al., 1998). In a majority of cases, for the average focal trough arch form and $10 \mathrm{~mm}$ and $20 \mathrm{~mm}$ focal trough widths, a large number of undiagnosable cases were found. This was most probably because the third molar and the IAN are not within the clearest plane of resolution (Figure 17). This is because not every person has the same mandibular arch form size and width. A number of panoramic radiographic machines have arch size selections that will change the parameters of the focal trough dimensions. However, the only available selections are usually adult and child. The adult selection invariably does not conform to the individual arch form but the "average" arch form. Therefore it is not surprising that there may be variable image quality due to variations in the position and relationship of the third molars in the posterior mandible. 
This discrepancy between the location of the third molar due to anatomic variability and focal trough shape invariably results in reduced clarity of the outline of the IAC. What is the optimal focal trough width if a standard focal trough arch form is used?

Due to the variability of mandibular arch forms, no signs were found significant in the standard arch form for the average adult of the panoramic radiograph machines that are used today. In the customized focal trough arch form, $20 \mathrm{~mm}$ focal trough width, two signs which were darkening of the root and narrowing of the canal, were found to be statistically significant to close proximity of the IAC. This focal trough width does correlate to some of the focal trough widths used in panoramic radiograph machines today that incorporate one focal trough arch form. (See Table 2)

All of the other focal trough widths (10 and 40mm- customized shape and 10, 20, and $40 \mathrm{~mm}$ - average shape) showed no significance in predicting an outcome measure. These findings suggested that the other four panoramic features may not significantly contribute to the prediction of close nerve involvement in any of the focal trough widths and focal trough shapes. Thus, in the present study, darkening of the root and narrowing of the canal in the focal trough width of $20 \mathrm{~mm}$-customized focal trough shape was defined as the diagnostic criterion of panoramic images to predict close neurovascular involvement of the third molar and the mandibular nerve. 


\section{FIGURE 17}

Average arch form focal trough. Note the third molars lying buccal to the focal plane

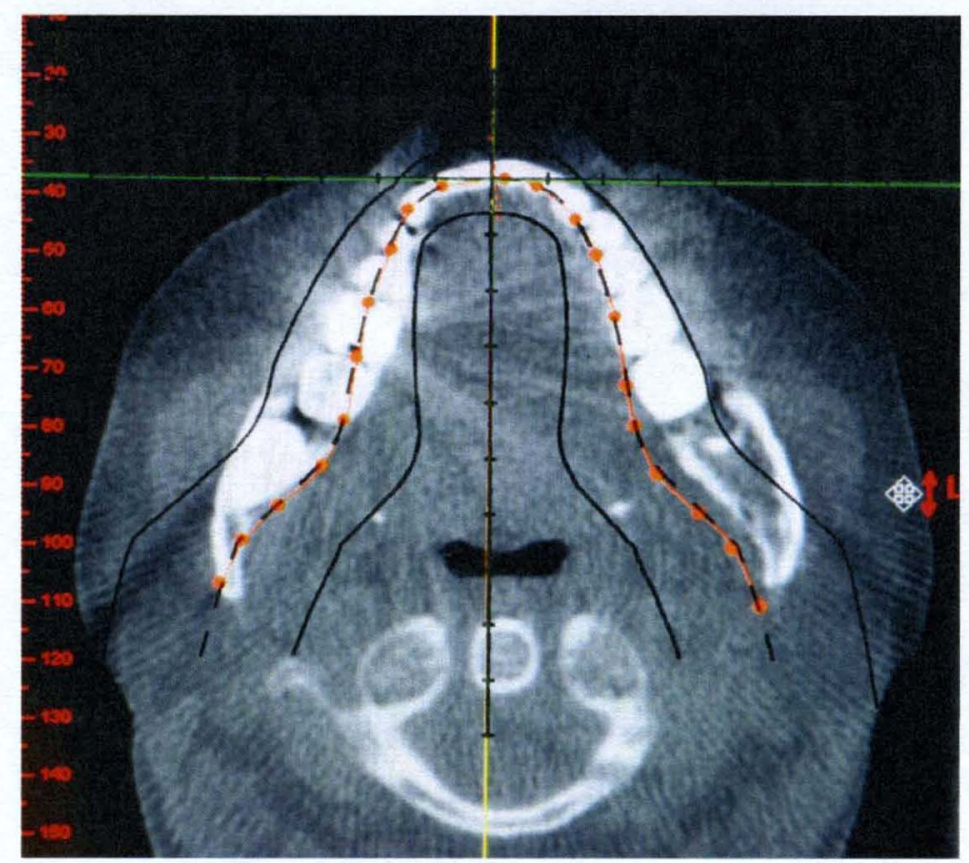

There were several potential weaknesses in this study. When using the acetate overlay in the axial view on the i-CAT for the average form focal trough, a $1 \mathrm{~cm}$ (acetate): 0.96 (i-CAT) ratio was used to fabricate the central plane of the reconstructed panoramic. This ratio was the closest to a 1:1 ratio for acetate to i-CAT in this fabrication. This may have introduced some discrepancy in the placement of the central plane in relation to the third molar, however it may be clinically insignificant. The number of teeth used in the study (50) was relatively small. It may be beneficial to increase the sample size and the number of observers to reduce inter-rater variability. A high number of cases in the average form focal trough, $10 \mathrm{~mm}$ and $20 \mathrm{~mm}$ were undiagnosable. This was most likely because the third molars were located outside of the central plane and had less clarity 
resolution. Many images were excluded because of this. Thus, it increased the inter-rater and intra-rater reliability in this study. Some of the images in each of the categories had unsharpness in the reconstructed panoramics that caused the observers difficulty in interpreting signs present or absent.

Inter-rater reliability varied somewhat in each focal trough form, focal trough width, and panoramic radiographic sign present. This indicated that there is variability between observers for panoramic radiographic signs present and seeing these signs on a panoramic can be subjective to the observer. Intra-rater reliability varied somewhat from fair to excellent in each focal trough form, focal trough width, and panoramic radiographic sign present. Observer \#1 had excellent consistency in all radiographic focal trough forms, focal trough widths, and panoramic radiographic signs present while observer \#2 had fair to poor results with a majority of her consistency being found in average focal trough form, $10 \mathrm{~mm}$ and $20 \mathrm{~mm}$. This was possibly due to the number of undiagnosable images present in those categories. Though there was quite a range in the agreement of the two observers, all observations were used in the statistical analysis. Prior tests of observer quality and panoramic radiographic sign level calibration may have reduced of the variability the data. 


\section{CHAPTER VI}

\section{SUMMARY AND CONCLUSIONS}

This study was conducted to determine if multiplanar curved transaxial images representing simulated panoramic images reconstructed from cone beam CT volumetric datasets, viewed with two different focal trough shapes and three different focal trough widths, influenced the ability of observers to identify high risk panoramic radiological signs associated with an intimate anatomic relationship between third molars and the IAC.

A series of 50 mandibular third molar teeth being less than $3 \mathrm{~mm}$ from the IAC were picked from the files of the i-CAT CBVCT at the University of Louisville Radiology Department. The 50 teeth were reconstructed into panoramic images with two different arch shapes (customized and average form), and three different focal trough widths at the third molar region $(10,20$, and $40 \mathrm{~mm})$. A slide show consisting of 300 slides (two arch forms and three different focal trough widths) was viewed by each observer. Six high risk radiological panoramic signs of the third molar related to the IAN were evaluated at each tooth (slide) and determined to be present or absent. Each observer utilized the CBVCT cross sectional analysis of the mandible to measure the distance, in millimeters, of the mandibular canal to the closest part of the mandibular third molar tooth. The observers also noted the position of the IAN in relation to the 
roots (buccal, lingual, or central) and the nerve to root association (notched, nothing, or nerve runs through root) in the mandibular cross section. Through these observations, statistical analysis was performed to determine if the teeth that have high risk radiological signs are in close proximity to the IAN, relative to the focal trough arch forms and the focal trough widths.

The results of the statistical analysis found observers were able to identify two panoramic radiological signs indicative of close proximity to the IAN using the customized focal trough arch form and the $20 \mathrm{~mm}$ focal trough width. These signs were darkening of the root and narrowing of the canal. These predictors have also been found to be of significance by other authors. (Blaeser et al., 2003; Bell 2004; Monaco et al., 2004; Sedaghatfar et al., 2005). It was also determined that no correlation was present between the location of the IAC (buccal, lingual, or central) and proximity of tooth root.

There was significant inter-rater agreement between the observers for a number of radiographic features. This indicates that there is some variability in signs that were present in the parameters not mentioned above by each observer. This also implies that there is subjective variability between observers when asked to indicate specific radiologic signs associated with third molar involvement with the IAC. Reliability for measurements, nerve position, and nerve root association all demonstrated high interrater agreement. Intra-rater reliability was inconsistent between observers.

Therefore, the null hypothesis must be rejected based on the data gathered for this project. There was a statistically significant difference in the customized focal trough arch form, and a statistically significant difference in the focal trough width with two 
panoramic high risk third molar radiological signs that predict close proximity of the third molar to the IAN for one of six conditions.

As CBVCT develops providing smaller voxel dimensions, this study could be conducted again using a customized focal trough form and a focal trough width of 17$23 \mathrm{~mm}$ to determine the ideal focal trough size and which panoramic radiological third molar high risk signs are present. With the higher resolution in future CBVCT, mandibular canal and third molar root high risk signs may be more visible when viewing reconstructed panoramics. In future panoramic radiographic machines, an initial scan of the patients' dentition would be made. From this initial scan, the boundaries of the focal trough and central plane would be made. A second true panoramic scan would be done using the patients arch form (customized from the initial scan) to fabricate the panoramic radiograph. This would produce the optimal image necessary to look for third molar high risk panoramic signs associated with close proximity to the mandibular canal. 


\section{REFERENCES}

Ahlqwist M., Gröndahl H-G. Prevalence of impacted teeth and associated pathology in middle-aged and older Swedish women. Community Dent Oral Epidemiol 1991;19:116119.

Baab, D. Caries and periodontitis associated with unerupted third molars. Oral Surg Oral Med Oral Path 1964;58(4):428-430.

Baba R, Ueda K, Okabe M. Using a flat-panel detector in high resolution cone beam CT for dental imaging. Dentomaxillofac Radiol 2004;33:285-290.

Bell GW. Use of dental panoramic tomographs to predict the relation between mandibular third molar teeth and the inferior alveolar nerve. Radiological and surgical findings, and clinical outcome. Br J Oral Macillofac Surg 2004; 42:21-27.

Blaeser B, August M, Donoff RB, Kaban L, and Dodson T. Panoramic radiography risk factors for inferior alveolar nerve injury after third molar extraction. J Oral Maxillofac Surg 2003;61:417-421.

Bouquet A, Coudert JL, Bourgeois D, Mazoyer JF, Bossard D. Contributions of reformatted computed tomography and panoramic radiography in the localization of third molars relative to the maxillary sinus. Oral Surg Oral Med Oral Pathol Oral Radiol Endod. 2004 Sep;98(3):342-7.

Brickley MR, Tanner M, Evans DJ, Edwards MJ, Armstrong RA, and Shepherd JP. Prevalence of third molars in dental practice attenders aged over 35. Comm Dent Health 1996;13:223-227. 
Carmichael FA, McGowan DA. Incidence of nerve damage following third molar removal: a west Scotland oral surgery research group study. Br J Oral Surg 1992;30:7882.

Carter RB, Keen EN. Intramandibular course of the inferior alveolar nerve. J Anat 1971;108: 433-440.

Chu FCS, Li TKL, Lui VKB, Newsome PRH, Chow RLK, and Cheund LK. Prevalence of impacted teeth and associated pathologies-a radiographic study of the Hong Kong Chinese population. Hong Kong Med J 2003;9:158-162.

Danforth R, Peck J, Hall P. Cone Beam Volume tomography: An Imaging Option for Diagnosis of Complex Mandibular Third Molar Anatomical Relationships. $J$ Calif Dent Assoc 2003;31:847-852.

Danforth, R, Peck, J, and Hall P. Cone beam volume tomography: an imaging option for diagnosis of complex mandibular third molar anatomical relationships. CDA Journal 2003;31:847-852.

Enciso R, Danforth RA, Alexandroni ES, Memon A, and Mah J. Third molar evaluation with cone-beam computerized tomography. Int J CARS. 2006;1:113-116

Garcia RI, Chauncey HH. The eruption of third molars in adults: a 10 year longitudinal study. Oral Surg 1989;68(1):9-13.

Glass BJ, McDavid WD, Welander U, Morris CR. The central plane of the image layer determined experimentally in various rotational panoramic x-ray machines. Oral Surg Oral Med Oral Pathol 1985;60: 104-112.

Harris CR, Jerman AC. Panoramic radiograph survey of embedded third molars. J Oral Surg 1971;29:122-125.

Hashimoto K, Arai Y, Iwai K, Araki M, Kawashima S, Terakado M. A comparison of anew limited cone beam computed tomography machine for dental use with 
amultidetector row helical CT machine. Oral Surg Oral Med Oral Pathol Oral Radiol Endod 2003;95:371-377.

Hilgers ML, Scarfe WC, Scheetz JP, Farman AG. Accuracy of linear temporomandibular joint measurements with cone beam computed tomography and digital cephalometric radiography. Am J Orthod Dentofacial Orthop 2005;128:803-811

Hugoson A, Kugelberg CF. The prevalence of third molars in a Swedish population. An epidemiological study. Comm Dent Health 1988: 5(2): 121-138.

Kaplan, RG. Mandibular third molars and post retention crowding. Am. J. Orthod 1974;66: 411-429.

Koong B, Pharoah MJ, Bulsara M, Tennant M. Methods of determining the relationship of the mandibular canal and third molars: a survey of Australian oral and maxillofacial surgeons. Aust Dent J. 2006 Mar;51(1):64-8.

Kress B, Gottschalk A, Anders L, Stippich C, Palm F, Bahren W, Sartor K. Highresolution dental magnetic resonance imaging of inferior alveolar nerve responses to the extraction of third molars. Eur Radiol. 2004 Aug;14(8):1416-20. Epub 2004 Mar 9.

LaBanc JP. Classification of nerve injuries. Oral Maxillofac Clin North Am 1992; $4(2): 285-296$.

Lascala CA, Panella J, Marques MM. Analysis of the accuracy of linear measurements obtained by cone beam computed tomography (CBCT-NewTom). Dentomaxillofac Radiol 2004;33:291-294.

Ludlow JB, Davies-Ludlow LE, Brooks SL, Howerton B. Dosimetry of 3 CBCT devices for oral and maxillofacial radiology: CB Mercuray, NewTom 3G and i-CAT. Dentomaxillofac Radiol. 2006;35(4):219-226.

Ludlow JB, Davies-Ludlow LE, Brooks SL. Dosimetry of two extraoral direct digital imaging devices: NewTom cone beam CT and Orthophos Plus DS panoramic unit. Dentomaxillofac Radiol. 2003;32(4):229-234. 
Lund TM, Manson-Hing LR. Relations between tooth positions and focal troughs of panoramic machines. Oral Surg Oral Med Oral Pathol 1975;40:285-293.

Maegawa H, Sano K, Kitagawa Y, Ogasawara T, Miyauchi K, Sekine J. Preoperative assessment of the relationship between the mandibular third molar and the mandibular canal by axial computed tomography with coronal and sagittal reconstruction. Oral Surg Oral Med Oral Pathol Oral Radiol Endod 2003;96:639-646.

Mahasantipiya PM, Savage NW, Monsour PAJ, and Wilson RJ. Narrowing of the inferior dental canal in relation to the lower third molars. Dentomaxillofac Radiol 2005;34:154163.

Manson-Hing LR, Lund TM, Ohba T. Japanese tooth positions and focal troughs of panoramic machines. Oral Surg Oral Med Oral Pathol 1976;41:797-802.

McDavid WD, Tronje G, Welander, U, Morris CR: Effects of errors in film speed and beam alignment of the image layer in rotational panoramic radiography. Oral Surg Oral Med Oral Pathol 1981;52:561-564.

Monaco G, Montevecchi M, Bonetti GA, Gatto MRA, and Checchi L. Reliability of panoramic radiography in evaluating the topographic relationship between the mandibular canal and impacted third molars. J Am Dent Assoc 2004;3:312-318.

Moshiri M, Scarfe WC, Hilgers ML, Scheetz JP, Silveira AM, and Farman AG. Accuracy of imaging methods from imaging plate and CBCT-derived lateral cephalometric images. Am J Orthod Dentofac Orthop accepted 2006.

Mozzo P, Procacci C, Tacconi A, Martini PT, Andreis IA. A new volumetric CT machinefor dental imaging based on the cone-beam technique: preliminary results. Eur Radiol 1998;8:1558-1564.

Mozzo P, Procacci C, Tacconi A. A new volumetric CT machine for dental imaging based on the cone-beam technique: Preliminary results. Eur Radiol 1998;8:1558-1564. 
Nakagawa Y, Kobayashi K, Ishii H, Mishima A, Ishii H, Asada K, and Ishibashi K.

Preoperative application of limited cone beam computerized tomography as an assessment tool before minor oral surgery. Int J Oral Maxillofac Surg 2002;31:322-327.

Nickoloff El, and Alderson PO. Radiation Exposures to Patients from CT: Reality, Public Perception, and Policy. AJR 201;177:285-287.

Nordenram A, Aas E, Hjorting-Hansen, E. Retinerade tander. Oral kirurgi 1986;98-120.

Nordenram A, Hultin M, Kjellman O, Ramstrom G. Indication for surgical removal of third molars: Study of 2630 cases. Swed Dent J 1987;11:23-29.

Nortje CJ, Farman AG, Joubert JJ. The radiographic appearance of the inferior dental canal: an additional variation. Br J Oral Surg 1977a; 15: 171-172.

Nortje CJ, Farman AG, Grotepass FW. Variation in the normal anatomy of the inferior dental (mandibular) canal: a retrospective study of panoramic radiographs from 3612 routine dental patients. Br J Oral Surg 1977b; 15: 55-63.

Nummikoski P, Prihoda T, Langlais R, McDavid W, Welander U, Tronje G. Dental and mandibular arch widths in three ethnic groups in Texas: A radiographic study. Oral Surg Oral Med Oral Pathol 1988;65:609-617.

Nummikoski P. The size and shape of the dental arch in different sex and ethnic groups. Masters Thesis, The University of Texas graduate School of Biomedical Science at San Antonio, San Antonio, Texas, USA 1985.

Ohman A, Kivijarvi K, Blomback U, Flygare L. Pre-operative radiographic evaluation of lower third molars with computed tomography. Dentomaxillofac Radiol. 2006 $\operatorname{Jan} ; 35(1): 30-5$.

Olasoji HO, Odusanya SA. Comparative study of third molar impaction in rural and urban areas of south western Nigeria. Odonto-Stomatologie Tropicale 2000-N90:25-28.

Oliver E. Le canal dentaire et son nerf chez l'adult. Ann Anat Pathol 1927; 4: 975-987. 
Osborn TP, Frederickson G Jr, Small IA, Torgerson TS. A prospective study of complications related to mandibular third molar surgery. J Oral Maxillofac Surg 1985;43:767-769.)

Pawelzik J, Cohnen M, Willers R, and Becker J, A comparison of conventional panoramic radiographs with volumetric computed tomography images in the preoperative assessment of impacted mandibular third molars. J Oral Maxillofac Surg 2002;60:979984.

Pell GJ, Gregory G. Report on a ten year study of a tooth division technique for the removal of impacted teeth. Am J Orthod 1942;28:660-669.

Peterson LJ, Ellis E, Hupp J, and Tucker M. Contemporary Oral and Maxillofacial Sirgery, $2^{\text {nd }}$ ed., C.V. Mosby Co., St. Louis, 1993;237-242.

Rood JP, Shehab AA. The radiological predilection of inferior alveolar nerve injury during third molar surgery. Br J Oral Maxillofac Surg 1990;28:20-25.

Rosenthal, RL. Extrusion of an impacted third molar for use as a fixed partial denture abutment. Gen Dent 1986;34(4): 2980-2991.

Scarfe WC, Farman AG, Sukovic P. Clinical applications of Cone-Beam Computed Tomography in Dental Practice. J Can Dent Assoc. 2006;72(1):75-80

Scarfe WC, Farman AG. Characteristics of the orthopantomograph OP 100.

Dentomaxillofac Radiol 1998;27:51-7.

Schersten E, Lysell L, and Rohlin M. Prevalence of impacted third molars in dental students. Swed Dent J 1989;13(1-2):7-13.

Schroll K. Anatomische und roentgenologische untersuchungen veber den verlang des nervus alveolaris inferior um unbezahten kieger. Acta Stomatol Belg 1975; 72: 771-776. 
Sedaghatfar M, August MA, Dodson TB. Panoramic radiographic findings as predictors of inferior alveolar nerve exposure following third molar extraction. J Oral Maxillofac Surg 2005;63: 3-7.

Smith AC, Barry SE, Chiong AY, Hadzakis D, Kha SL, Mok SC. Inferior alveolar nerve damage following removal of mandibular third molar tooth. A prospective study using panoramic radiography. Aust Dent J 1997;42:149-152.

Stedman's medical dictionary. 25th ed. Baltimore: Williams \& Wilkins; 1990. Impaction; p. 956.

Sukovic P. Cone beam computed tomography in craniofacial imaging. Orthod CraniofacRes 2003;6(Suppl 1):31-36.

Tate, TE. Impactions:Observe or Treat?. J Calif Dent Assoc 1994;22(6): 59-64.

Tevepaugh, DB, Dodson, TB. Are Mandibular Third Molars a Risk Factor for Angle Fractures? A retrospective Cohort Study. J Oral Maxillofac Surg 1995;53:646-649. Tronje G, Eliasson S, Julin P, Welander U. Image distortion in rotational panoramic radiography. II. Vertical distances. Acta Radiol Diagn Stockh 1981 a;22:449-455.

Tronje G, Welander U, McDavid WD, and Morris CR. Image distortion in rotational panoramic radiography. I. General considerations. Acta Radiol Diagn Stockh $1981 b ; 22: 295-299$.

Tronje G, Welander U, McDavid WD, Morris CR. Image distortion in rotational panoramic radiography. III. Inclined objects. Acta Radiol Diagn Stockh 1981c;22:585592.

Tulloch JFC, and Antczak-Bouckoms AA. Decision analysis in the evaluation of clinical strategies for the management of mandibular third molars. J Dent Educ 1987;51:652-658. 
Van Gool AV, Ten Bosch JJ, Boering G. Clinical consequences of complaints and complications after removal of the mandibular third molar. Int J Oral Surg 1977; 6: 2937.

Valmaseda-Castellon E, Berini-Aytes L. Inferior alveolar nerve damage after lower third molar surgical extraction: A prospective study of 1,117 surgical extractions. Oral Surg Oral Med Oral Pathol Oral Radiol Endod 2001;92:377-383.

Welander U, Nummikoski P, Tronje G, McDavid WD, Legrell PE, and Langlais RP. Standard forms of dentition and mandible for applications in rotational panoramic radiography. Dentomaxillofac Radiol 1989;18:60-67.

White SC and Pharoah M J. Panoramic radiography. Oral radiology: principles and interpretation St. Louis: C V. Mosby Inc.; 2000: 205-216.

Yamaoka M, Furusawa K, Ikeda M, Hasegawa T. Root resorption of mandibular second molar teeth associated with the presence of the third molars. Australian Dental Journal 1999;44:112-116.

Zuniga JR, LaBanc JP. Advances in microsurgical nerve repair. J Oral Maxillofac Surg 1993; 51(suppl 1):62-68. 


\section{Appendix A-SAS raw data}

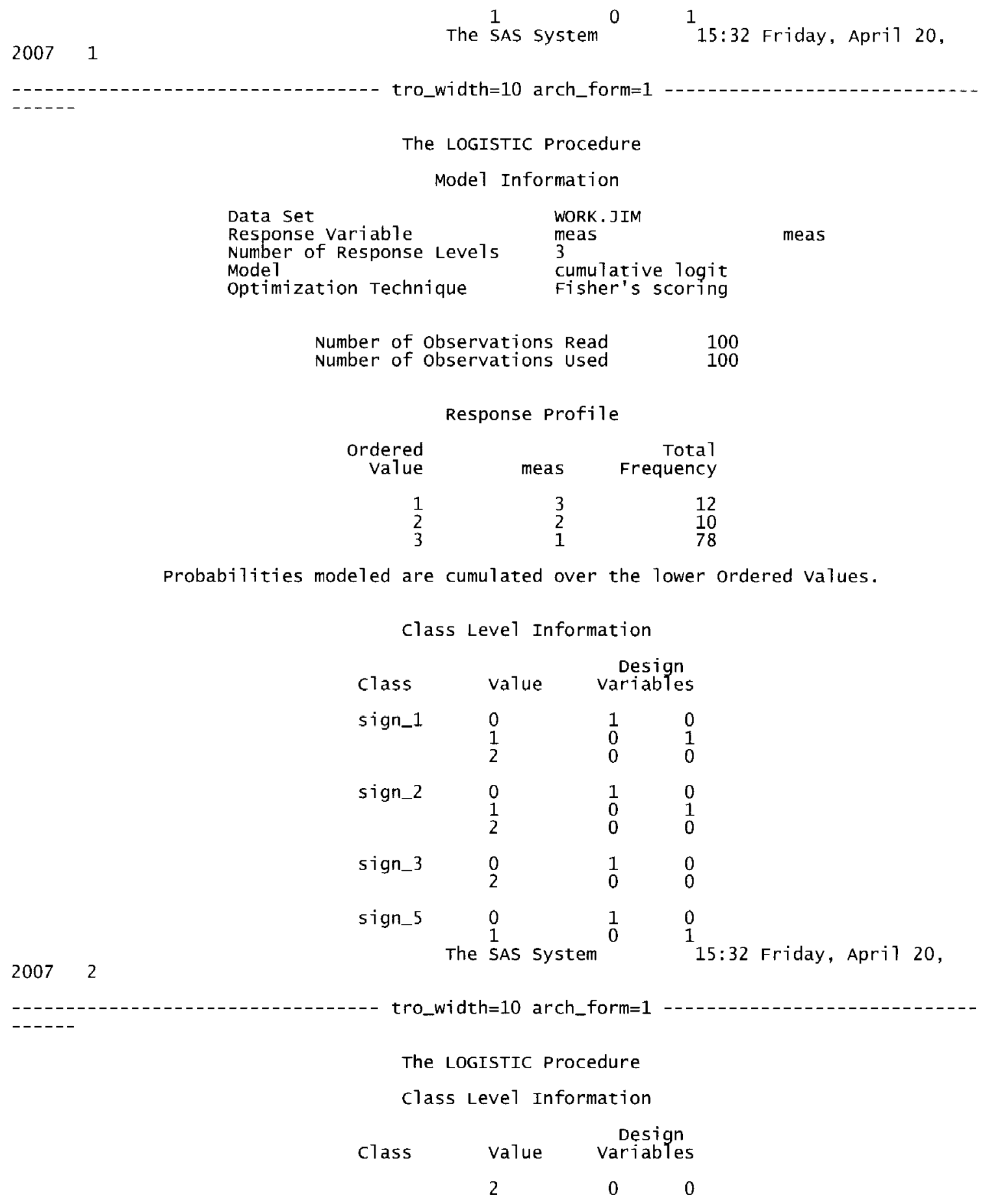




$\begin{array}{llll}\text { sign_6 } & 0 & 1 & 0 \\ & \frac{1}{2} & 0 & 1 \\ \text { ner_pos } & 1 & 0 & 0 \\ & 2 & 1 & 0 \\ \text { n_r_inv } & 3 & 0 & 1 \\ & \frac{1}{2} & 1 & \\ & & 0 & \end{array}$

Model Convergence Status

Quasi-complete separation of data points detected.

WARNING: The maximum likelihood estimate may not exist.

WARNING: The LOGISTIC procedure continues in spite of the above warning. Results shown are based on the last maximum likelihood iteration. validity of the model fit is questionable.

Score Test for the Proportional odds Assumption

Chi-square DF $\mathrm{Pr}>\mathrm{Chisq}$

$29.3608 \quad 10 \quad 0.0011$

Model Fit statistics

$\begin{array}{lcc}\text { Criterion } & \begin{array}{r}\text { Intercept } \\ \text { only }\end{array} & \begin{array}{r}\text { Intercept } \\ \text { and } \\ \text { Covariates }\end{array} \\ \text { AIC } & 139.698 & 145.243 \\ \text { SC } & 144.908 & 176.505 \\ -2 \text { Log L } & 135.698 & 121.243 \\ & \text { The SAS System } & 15: 32 \text { Friday, Apri1 20, }\end{array}$

20073

tro_width=10 arch_form=1

$-----$

The LOGISTIC Procedure

WARNING: The validity of the model fit is questionable.

$$
\mathrm{R} \text {-Square } \quad 0.1346 \quad \text { Max-rescaled } \mathrm{R} \text {-square } 0.1812
$$

Testing Global Nu11 Hypothesis: BETA=0

$\begin{array}{lrrr}\text { Test } & \text { Chi-Square } & \text { DF } & \text { Pr }>\text { Chisq } \\ \text { Likelihood Ratio } & 14.4546 & 10 & 0.1532 \\ \text { Score } & 11.8755 & 10 & 0.2935 \\ \text { wald } & 9.6635 & 10 & 0.4705\end{array}$

Type 3 Analysis of Effects

$\begin{array}{lrrr}\text { Effect } & \text { DF } & \begin{array}{r}\text { wald } \\ \text { Chi-square }\end{array} & \mathrm{Pr}>\text { Chisq } \\ \text { sign_1 } & 2 & 0.7006 & 0.7045 \\ \text { sign_2 } & 1 & 1.0352 & 0.3089 \\ \text { sign_3 } & 1 & 0.0012 & 0.9727 \\ \text { sign_4 } & 1 & 0.7689 & 0.3806 \\ \text { sign_5 } & 1 & 0.9812 & 0.3219 \\ \text { sign_6 } & 1 & 1.1859 & 0.2761 \\ \text { ner_pos } & 2 & 1.9888 & 0.3699\end{array}$




$$
\text { n_r_inv } \quad 1 \quad 2.5005 \quad 0.1138
$$

NOTE: The following parameters have been set to 0 , since the variables are a 1 inear combination of other variables as shown.

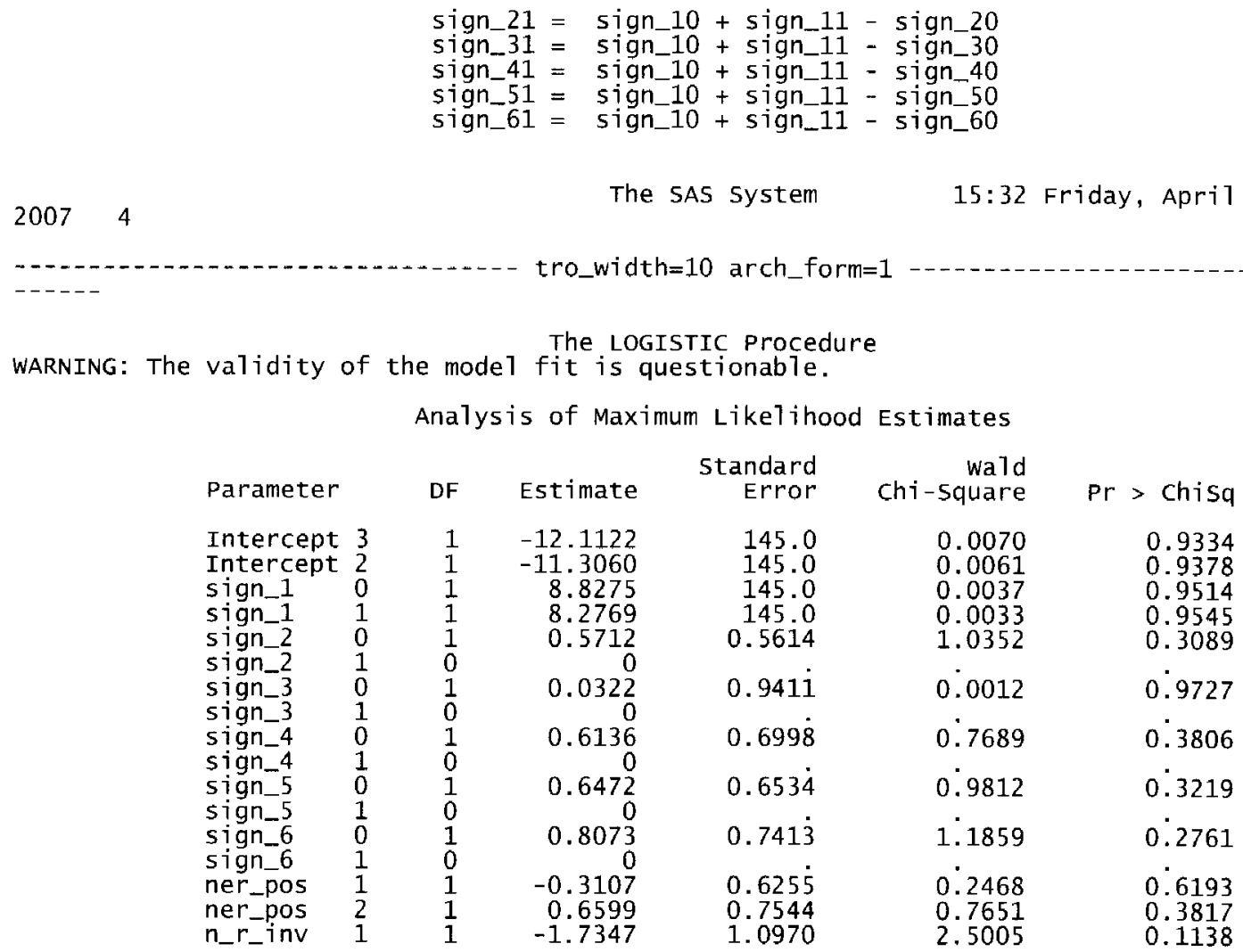

Odds Ratio Estimates

\begin{tabular}{|c|c|c|c|c|}
\hline \multicolumn{2}{|l|}{ Effect } & $\begin{array}{l}\text { Point } \\
\text { Estimate }\end{array}$ & \multicolumn{2}{|c|}{$\begin{array}{c}95 \% \text { wald } \\
\text { Confidence Limits }\end{array}$} \\
\hline $\begin{array}{l}\text { sign_1 } \\
\text { sign_1 } \\
\text { sign_2 } \\
\text { sign_3 } \\
\text { sign_4 } \\
\text { sign_5 } \\
\text { sign_6 } \\
\text { ner_pos } \\
\text { ner_pos } \\
\text { n_r_inv }\end{array}$ & 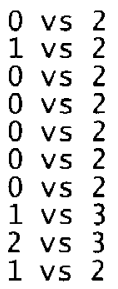 & $\begin{array}{r}>999.999 \\
>999.999 \\
1.770 \\
1.033 \\
1.847 \\
1.910 \\
2.242 \\
0.733 \\
1.935 \\
0.176\end{array}$ & $\begin{array}{r}<0.001 \\
<0.001 \\
0.589 \\
0.163 \\
0.469 \\
0.531 \\
0.524 \\
0.215 \\
0.441 \\
0.021\end{array}$ & $\begin{array}{r}>999.999 \\
>999.999 \\
5.320 \\
6.532 \\
7.280 \\
6.875 \\
9.586 \\
2.497 \\
8.486 \\
1.515\end{array}$ \\
\hline
\end{tabular}

$2007 \quad 5$

The SAS system

15:32 Friday, Apri1 20,

tro width=10 arch form=1

The LOGISTIC Procedure

WARNING: The validity of the model fit is questionable. 
Association of Predicted Probabilities and observed Responses

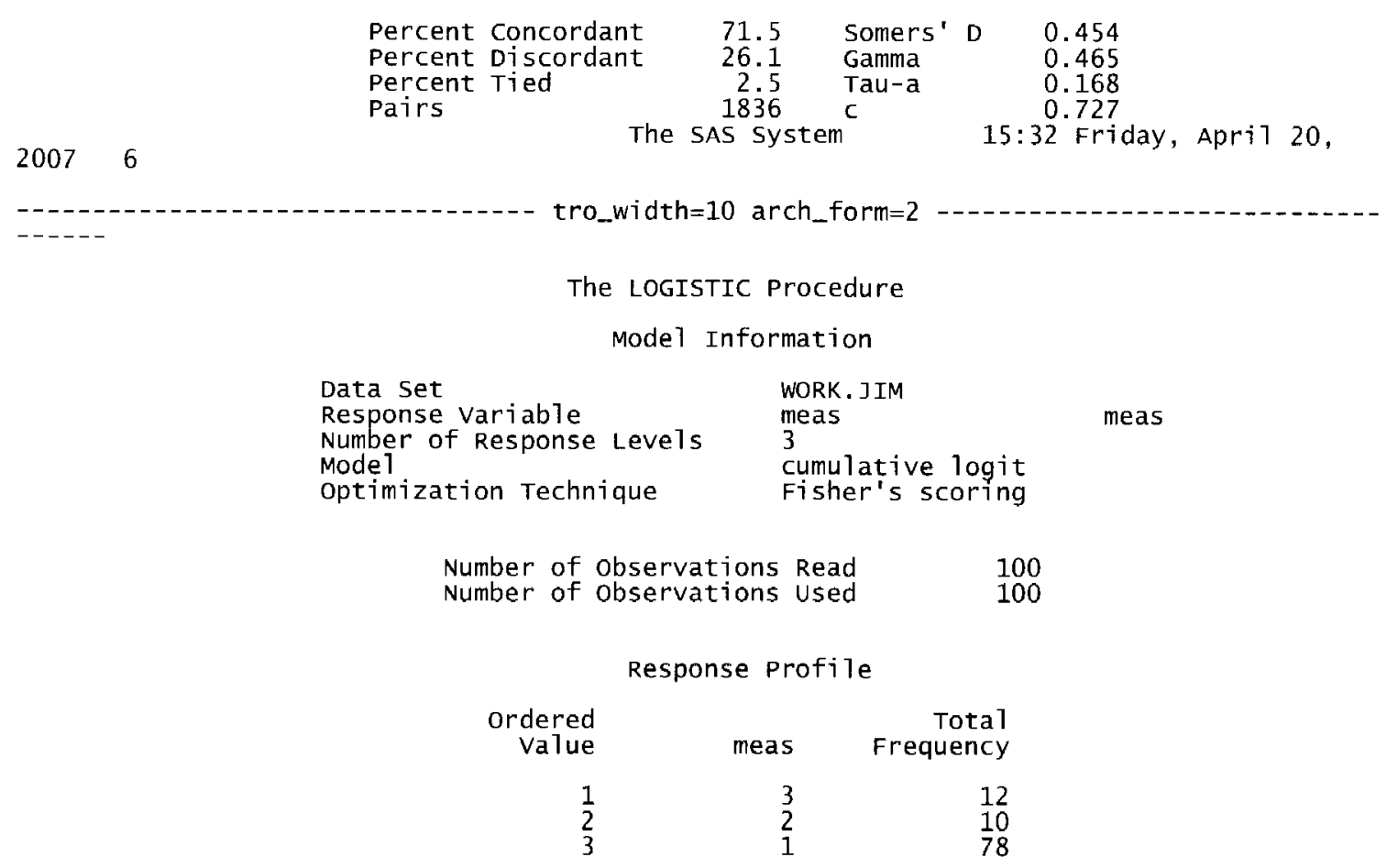

Probabilities modeled are cumulated over the lower ordered values.

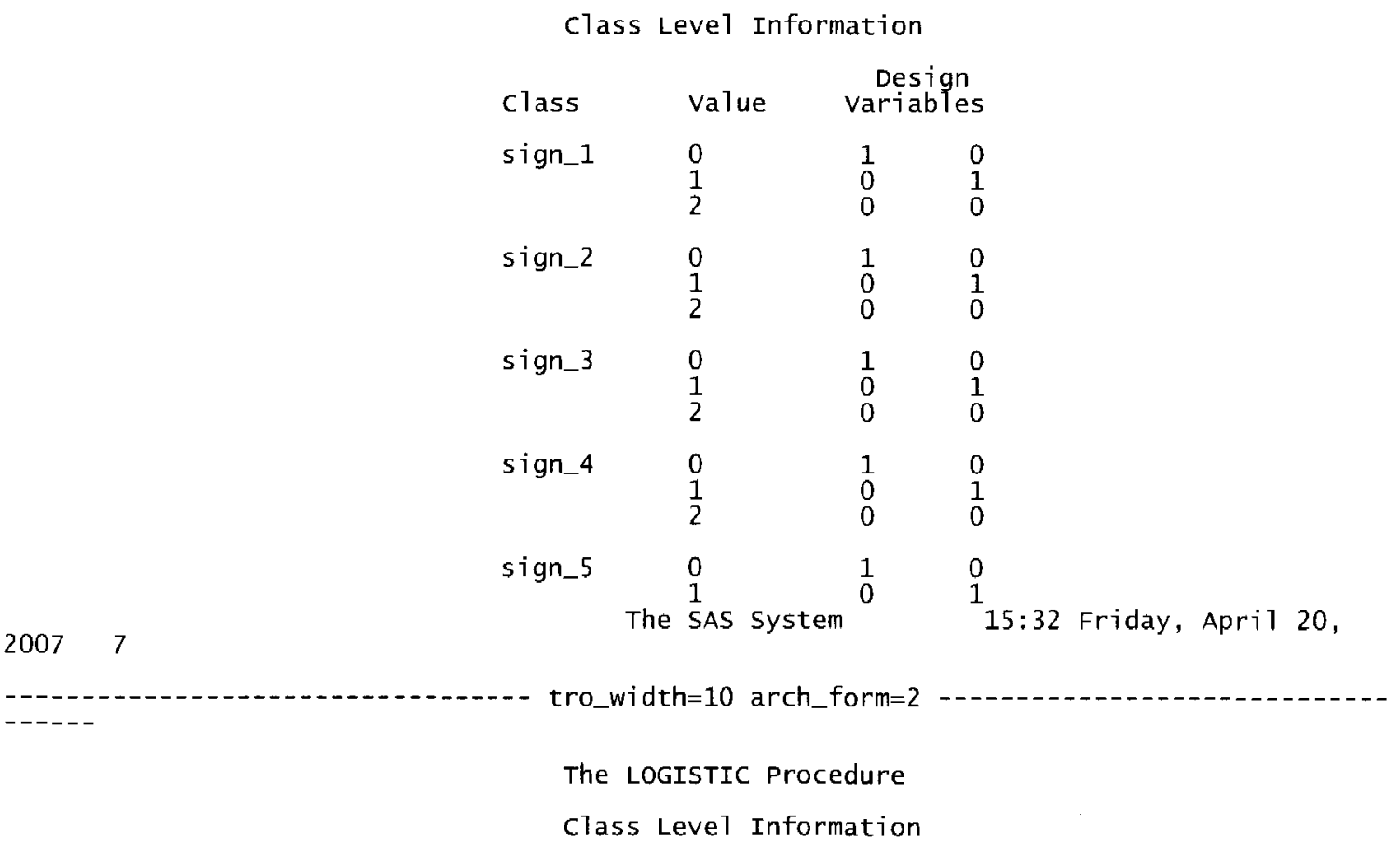




\begin{tabular}{cccc} 
class & value & \multicolumn{2}{c}{$\begin{array}{c}\text { Design } \\
\text { variables }\end{array}$} \\
& 2 & 0 & 0 \\
sign_6 & 0 & 1 & 0 \\
& 1 & 0 & 1 \\
ner_pos & 2 & 0 & 0 \\
& 1 & 1 & 0 \\
n_r_inv & 3 & 0 & 1 \\
& 1 & 1 & \\
& 2 & 0 & \\
Mode1 Convergence status
\end{tabular}

Quasi-complete separation of data points detected.

WARNING: The maximum likelihood estimate may not exist.

WARNING: The LOGISTIC procedure continues in spite of the above warning. Results shown are

based on the last maximum likelihood iteration. Validity of the model fit is questionable.

Score Test for the Proportional odds Assumption

$$
\begin{array}{ccc}
\text { Chi-square } & \text { DF } & \text { Pr }>\text { Chisq } \\
43.2539 & 10 & <.0001 \\
\text { Model Fit } & & \\
\text { Statistics } &
\end{array}
$$

$\begin{array}{lrr}\text { Criterion } & \begin{array}{r}\text { Intercept } \\ \text { On1y }\end{array} & \begin{array}{r}\text { Intercept } \\ \text { and } \\ \text { Covariates }\end{array} \\ \text { AIC } & 139.698 & 142.186 \\ \text { SC } & 144.908 & 173.448 \\ -2 \text { Log L } & 135.698 & 118.186\end{array}$

$2007 \quad 8$

The LOGISTIC Procedure

WARNING: The validity of the model fit is questionable.

$$
\begin{array}{lccc}
\text { R-Square } & 0.1606 & \text { Max-rescaled R-Square } & 0.2163 \\
& \text { Testing Global Null Hypothesis: BETA=0 } & \\
\text { Test } & \text { Chi-Square } & \text { DF } & \mathrm{Pr}>\text { Chisq } \\
\text { Likelihood Ratio } & 17.5118 & 10 & 0.0638 \\
\text { Score } & 14.1480 & 10 & 0.1663 \\
\text { Wald } & 11.4684 & 10 & 0.3222
\end{array}
$$

$\begin{array}{rrr}\text { chi-square } & \text { DF } & \text { Pr }>\text { chisq } \\ 17.5118 & 10 & 0.0638 \\ 14.1480 & 10 & 0.1663 \\ 11.4684 & 10 & 0.3222\end{array}$

Type 3 Analysis of Effects

$\begin{array}{lrrr}\text { Effect } & \text { DF } & \begin{array}{r}\text { wald } \\ \text { Chi-square }\end{array} & \text { Pr }>\text { Chisq } \\ \text { sign_1 } & 2 & 1.3862 & 0.5000\end{array}$




$\begin{array}{llll}\text { sign_2 } & 1 & 0.5179 & 0.4717 \\ \text { sign_3 } & 1 & 0.1257 & 0.7229 \\ \text { sign_4 } & 1 & 0.0026 & 0.9593 \\ \text { sign_5 } & 1 & 1.1156 & 0.2909 \\ \text { sign_6 } & 1 & 2.0780 & 0.1494 \\ \text { ner_pos } & 2 & 3.4134 & 0.1815 \\ \text { n_r_inv } & 1 & 2.9514 & 0.0858\end{array}$

NOTE: The following parameters have been set to 0 , since the variables are a 1 inear combination of other variables as shown.

20079

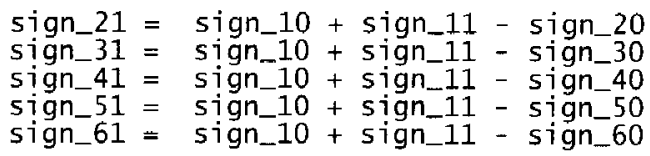

The SAS system

15:32 Friday, Apri1 20,

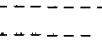

tro_width=10 arch_form=2

The LOGISTIC Procedure

WARNING: The validity of the model fit is questionable. Analysis of Maximum Likelihood Estimates

\begin{tabular}{|c|c|c|c|c|c|c|}
\hline Parameter & & DF & Estimate & $\begin{array}{c}\text { Standard } \\
\text { Error }\end{array}$ & $\begin{array}{r}\text { wald } \\
\text { Chi-square }\end{array}$ & $\mathrm{Pr}>$ Chisq \\
\hline $\begin{array}{l}\text { Intercept } \\
\text { Intercept } \\
\text { sign_1 } \\
\text { sign_1 } \\
\text { sign_2 }\end{array}$ & $\begin{array}{l}3 \\
2 \\
0 \\
1 \\
0\end{array}$ & $\begin{array}{l}1 \\
1 \\
1 \\
1 \\
1\end{array}$ & $\begin{array}{r}-1.4657 \\
-0.6179 \\
-13.1590 \\
-14.4421 \\
0.7074\end{array}$ & $\begin{array}{r}0.5088 \\
0.4732 \\
223.8 \\
223.8 \\
0.9830\end{array}$ & $\begin{array}{l}8.2977 \\
1.7053 \\
0.0035 \\
0.0042 \\
0.5179\end{array}$ & $\begin{array}{l}0.0040 \\
0.1916 \\
0.9531 \\
0.9485 \\
0.4717\end{array}$ \\
\hline & $\begin{array}{l}1 \\
0\end{array}$ & $\begin{array}{l}0 \\
1\end{array}$ & $\begin{array}{r}0 \\
-0.5752\end{array}$ & $1.622 \dot{4}$ & 0.1257 & 0.7229 \\
\hline $\begin{array}{l}\text { sign } 3 \\
\text { sign_4 }\end{array}$ & $\begin{array}{l}1 \\
0\end{array}$ & $\begin{array}{l}0 \\
1\end{array}$ & $\begin{array}{r}0 \\
11.4298\end{array}$ & $223 . \dot{8}$ & 0.0026 & 0.9593 \\
\hline $\begin{array}{l}\operatorname{sign} 44 \\
\operatorname{sign}-5 \\
\operatorname{sign} 5\end{array}$ & $\begin{array}{l}1 \\
0 \\
1\end{array}$ & $\begin{array}{l}0 \\
1 \\
0\end{array}$ & $\begin{array}{r}0 \\
1.3023\end{array}$ & $1.2330^{\circ}$ & 1.1156 & 0.2909 \\
\hline $\begin{array}{l}\text { sign_5 } \\
\text { sign_6 } \\
\text { sign_6 }\end{array}$ & $\begin{array}{l}1 \\
0 \\
1\end{array}$ & $\begin{array}{l}1 \\
0\end{array}$ & $\begin{array}{r}2.0820 \\
0\end{array}$ & $1.444 \dot{3}$ & 2.0780 & 0.1494 \\
\hline $\begin{array}{l}\text { ner_pos } \\
\text { ner_pos } \\
\text { n_r_inv }\end{array}$ & $\begin{array}{l}1 \\
1 \\
2 \\
1\end{array}$ & $\begin{array}{l}1 \\
1 \\
1\end{array}$ & $\begin{array}{l}-1.0939 \\
-0.1470 \\
-1.9083\end{array}$ & $\begin{array}{l}0.6335 \\
0.6938 \\
1.1108\end{array}$ & $\begin{array}{l}2.9822 \\
0.0449 \\
2.9514\end{array}$ & $\begin{array}{l}0.0842 \\
0.8323 \\
0.0858\end{array}$ \\
\hline
\end{tabular}

odds Ratio Estimates

\begin{tabular}{|c|c|c|c|c|}
\hline \multicolumn{2}{|l|}{ Effect } & $\begin{array}{r}\text { Point } \\
\text { Estimate }\end{array}$ & \multicolumn{2}{|c|}{$\begin{array}{l}95 \% \text { wald } \\
\text { Confidence Limits }\end{array}$} \\
\hline $\begin{array}{l}\text { sign_1 } \\
\text { sign_1 } \\
\text { sign_2 } \\
\text { sign_3 } \\
\text { sign_4 } \\
\text { sign_5 } \\
\text { sign_6 } \\
\text { ner_pos } \\
\text { ner_pos } \\
\text { n_r_inv }\end{array}$ & $\begin{array}{lll}0 & v s & 2 \\
1 & v s & 2 \\
0 & v s & 2 \\
0 & v s & 2 \\
0 & v s & 2 \\
0 & v s & 2 \\
0 & v s & 2 \\
1 & v s & 3 \\
2 & v s & 3 \\
1 & v s & 2\end{array}$ & $\begin{array}{r}<0.001 \\
<0.001 \\
2.029 \\
0.563 \\
>999.999 \\
3.678 \\
8.021 \\
0.335 \\
0.863 \\
0.148\end{array}$ & $\begin{array}{r}<0.001 \\
<0.001 \\
0.295 \\
0.023 \\
<0.001 \\
0.328 \\
0.473 \\
0.097 \\
0.222 \\
0.017\end{array}$ & $\begin{array}{r}>99 \\
>99 \\
1 \\
1 \\
>99 \\
4 \\
13\end{array}$ \\
\hline
\end{tabular}




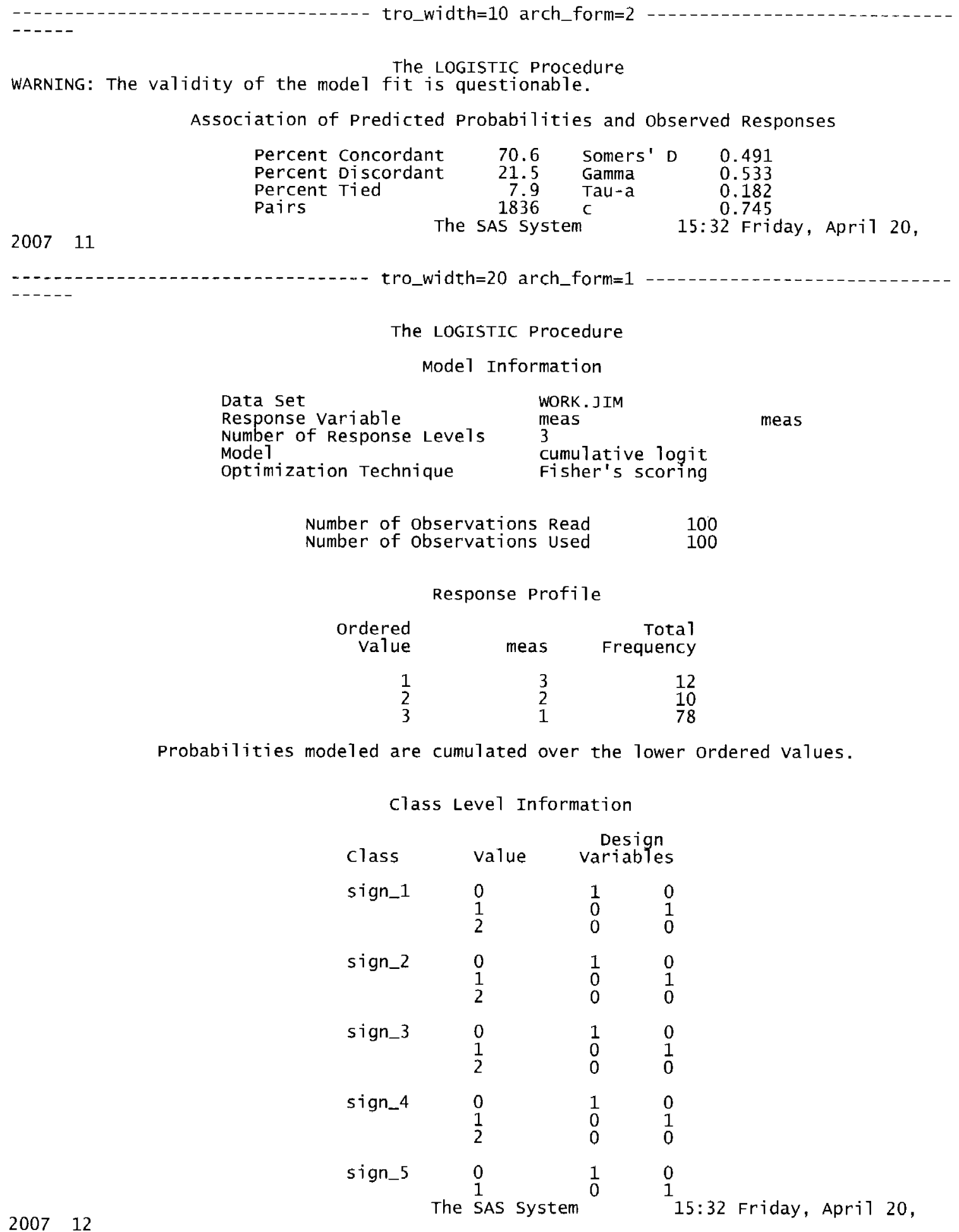


tro_width $=20$ arch_form $=1$

The LOGISTIC Procedure

class Level Information

\begin{tabular}{llcl} 
Class & value & \multicolumn{2}{c}{$\begin{array}{c}\text { Design } \\
\text { variabies }\end{array}$} \\
sign_6 & 2 & 0 & 0 \\
& 0 & 1 & 0 \\
& 1 & 0 & 1 \\
ner_pos & 2 & 0 & 0 \\
& 1 & 1 & 0 \\
n_r_inv & 2 & 0 & 1 \\
& 3 & 0 & 0 \\
& 1 & 1 &
\end{tabular}

Model Convergence Status

convergence criterion (GCONV=1E-8) satisfied.

Score Test for the Proportional odds Assumption

$$
\begin{array}{rrr}
\text { Chi-Square } & \text { DF } & \text { Pr }>\text { Chisq } \\
57.9659 & 10 & <.0001
\end{array}
$$

Model Fit statistics

$\begin{array}{lrr}\text { Criterion } & \begin{array}{r}\text { Intercept } \\ \text { Only }\end{array} & \begin{array}{r}\text { Intercept } \\ \text { and } \\ \text { Covariates }\end{array} \\ \text { AIC } & 139.698 & 136.577 \\ \text { SC } & 144.908 & 167.839 \\ -2 \text { Log L } & 135.698 & 112.577\end{array}$

$$
\text { R-Square } \quad 0.2064 \text { Max-rescaled R-Square } 0.2780
$$

$2007 \quad 13$

The SAS system

15:32 Friday, Apri1 20,

tro_width=20 arch_form=1

The LOGISTIC Procedure

Testing Global Null Hypothesis: BETA=0

$\begin{array}{lrrr}\text { Test } & \text { Chi-square } & \text { DF } & \text { Pr > Chisq } \\ \text { Likelihood Ratio } & 23.1210 & 10 & 0.0103 \\ \text { Score } & 18.1045 & 10 & 0.0532 \\ \text { Wald } & 15.6884 & 10 & 0.1089\end{array}$

Type 3 Analysis of Effects

wald
Effect




$\begin{array}{llll}\text { sign_1 } & 2 & 6.8825 & 0.0320 \\ \text { sign_2 } & 1 & 1.0038 & 0.3164 \\ \text { sign_3 } & 1 & 0.0000 & 0.9978 \\ \text { sign_4 } & 1 & 2.2848 & 0.1306 \\ \text { sign_5 } & 1 & 1.2240 & 0.2686 \\ \text { sign_6 } & 1 & 3.9473 & 0.0469 \\ \text { ner_pos } & 2 & 0.4290 & 0.8069 \\ \text { n_r_inv } & 1 & 2.3510 & 0.1252\end{array}$

NOTE: The following parameters have been set to 0 , since the variables are a linear combination of other variables as shown.

$$
\begin{aligned}
& \text { sign_21 }=\text { sign_10+sign_11-sign_20 } \\
& \text { sign_31 }=\text { sign_10+sign_11-sign_30 } \\
& \text { sign_41 }=\text { sign_10+sign_11 - sign_40 } \\
& \text { sign_51 }=\text { sign_10+sign_11 - sign_50 } \\
& \text { sign_61 }=\text { sign_10+sign_11 - sign_60 }
\end{aligned}
$$

\begin{tabular}{|c|c|c|c|c|c|}
\hline Parameter & DF & Estimate & $\begin{array}{r}\text { Standard } \\
\text { Error }\end{array}$ & $\begin{array}{r}\text { wald } \\
\text { Chi-square }\end{array}$ & $\mathrm{Pr}>\mathrm{ChiSq}$ \\
\hline $\begin{array}{ll}\text { Intercept } & 3 \\
\text { Intercept } & 2 \\
\text { sign_1 } & 0 \\
\text { sign_1 } & 1 \\
\text { sign_2 } & 0 \\
\text { sign_2 } & 1 \\
\text { sign_3 } & 0 \\
\text { sign_3 } & 1\end{array}$ & $\begin{array}{l}1 \\
1 \\
1 \\
1 \\
1 \\
0 \\
1 \\
0\end{array}$ & $\begin{array}{r}-0.3687 \\
0.5256 \\
-4.7410 \\
-5.7130 \\
-0.5649 \\
0 \\
0.00367 \\
0\end{array}$ & $\begin{array}{r}1.5209 \\
1.5220 \\
2.4772 \\
2.4699 \\
0.5638 \\
1.3165 \\
\text { AS system }\end{array}$ & $\begin{array}{l}0.0588 \\
0.1192 \\
3.6628 \\
5.3503 \\
1.0038 \\
0.0000 \\
15.32\end{array}$ & $\begin{array}{l}0.8084 \\
0.7299 \\
0.0556 \\
0.0207 \\
0.3164 \\
0.9978 \\
\end{array}$ \\
\hline
\end{tabular}

Analysis of Maximum Likelihood Estimates

\begin{tabular}{|c|c|c|c|c|c|c|}
\hline \multicolumn{2}{|c|}{ Parameter } & DF & Estimate & $\begin{array}{r}\text { Standard } \\
\text { Error }\end{array}$ & $\begin{array}{r}\text { wald } \\
\text { chi-Square }\end{array}$ & $\mathrm{Pr}>$ Chisq \\
\hline sign_4 & 0 & 1 & 1.7855 & 1.1812 & 2.2848 & 0.1306 \\
\hline $\begin{array}{l}\text { sign_4 } \\
\text { sign_5 }\end{array}$ & $\begin{array}{l}1 \\
0\end{array}$ & $\begin{array}{l}0 \\
1\end{array}$ & 0.7854 & $0.709 \dot{9}$ & 1.2240 & 0.2686 \\
\hline sign_5 & 1 & 0 & & & & \\
\hline $\begin{array}{l}\text { sign_6 } \\
\text { sign-6 }\end{array}$ & $\begin{array}{l}0 \\
1\end{array}$ & $\begin{array}{l}1 \\
0\end{array}$ & 2.2603 & 1.1377 & 3.9473 & 0.0469 \\
\hline $\begin{array}{l}\text { ner_pos } \\
\text { ner_pos } \\
\text { n_r_inv }\end{array}$ & $\begin{array}{l}1 \\
1 \\
2 \\
1\end{array}$ & $\begin{array}{l}0 \\
1 \\
1 \\
1\end{array}$ & $\begin{array}{l}-0.3992 \\
-0.0784 \\
-1.7119\end{array}$ & $\begin{array}{l}0.6404 \\
0.7580 \\
1.1165\end{array}$ & $\begin{array}{l}0.3886 \\
0.0107 \\
2.3510\end{array}$ & $\begin{array}{l}0.5330 \\
0.9177 \\
0.1252\end{array}$ \\
\hline
\end{tabular}

$2007 \quad 14$

tro_width $=20$ arch_form $=1$

\begin{tabular}{|c|c|c|c|c|}
\hline \multicolumn{2}{|l|}{ Effect } & $\begin{array}{l}\text { Point } \\
\text { Estimate }\end{array}$ & \multicolumn{2}{|c|}{$\begin{array}{c}95 \% \text { wald } \\
\text { Confidence Limits }\end{array}$} \\
\hline $\begin{array}{l}\text { sign_1 } \\
\text { sign_-1 } \\
\text { sign_-2 } \\
\text { sign_3 } \\
\text { sign_-4 } \\
\text { sign_5 } \\
\text { sign_6 } \\
\text { ner_pos } \\
\text { ner_pos }\end{array}$ & $\begin{array}{lll}0 & \text { vs } & 2 \\
1 & \text { vs } & 2 \\
0 & \text { vs } & 2 \\
0 & \text { vs } & 2 \\
0 & \text { vs } & 2 \\
0 & \text { vs } & 2 \\
0 & \text { vs } & 2 \\
1 & \text { vs } & 3 \\
2 & \text { vs } & 3\end{array}$ & $\begin{array}{l}0.009 \\
0.003 \\
0.568 \\
1.004 \\
5.963 \\
2.193 \\
9.586 \\
0.671 \\
0.925\end{array}$ & $\begin{array}{r}<0.001 \\
<0.001 \\
0.188 \\
0.076 \\
0.589 \\
0.546 \\
1.031 \\
0.191 \\
0.209\end{array}$ & $\begin{array}{r}1.121 \\
0.418 \\
1.716 \\
13.248 \\
60.383 \\
8.817 \\
89.126 \\
2.354 \\
4.085\end{array}$ \\
\hline
\end{tabular}

The LOGISTIC Procedure

Analysis of Maximum Likelihood Estimates

Odds Ratio Estimates 

n_r_inv 1 vs 2
0.181
0.020
1.610

Association of Predicted Probabilities and observed Responses

$\begin{array}{lrll}\text { Percent Concordant } & 78.0 & \text { Somers }^{\prime} \text { D } & 0.583 \\ \text { Percent Discordant } & 19.7 & \text { Gamma } & 0.596 \\ \text { Percent Tied } & 2.3 & \text { Tau-a } & 0.216 \\ \text { Pairs } & 1836 & \text { C } & 0.791\end{array}$

The SAS System

15:32 Friday, Apri1 20

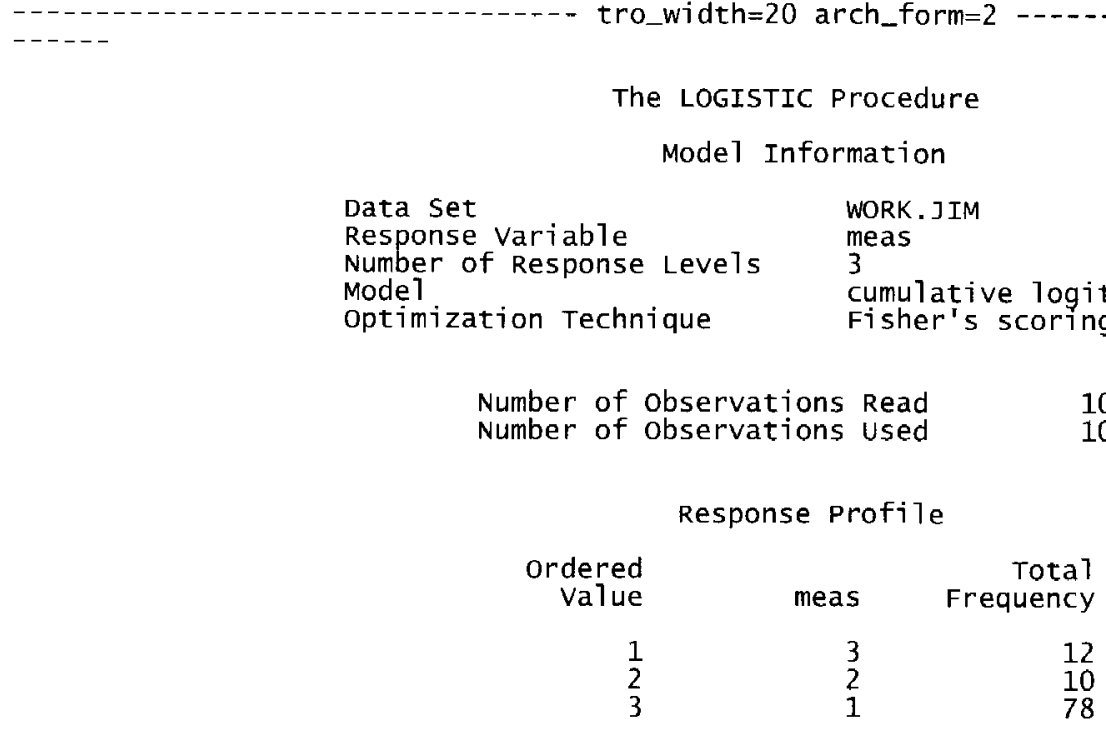

Probabilities modeled are cumulated over the lower ordered values.

Class Level Information

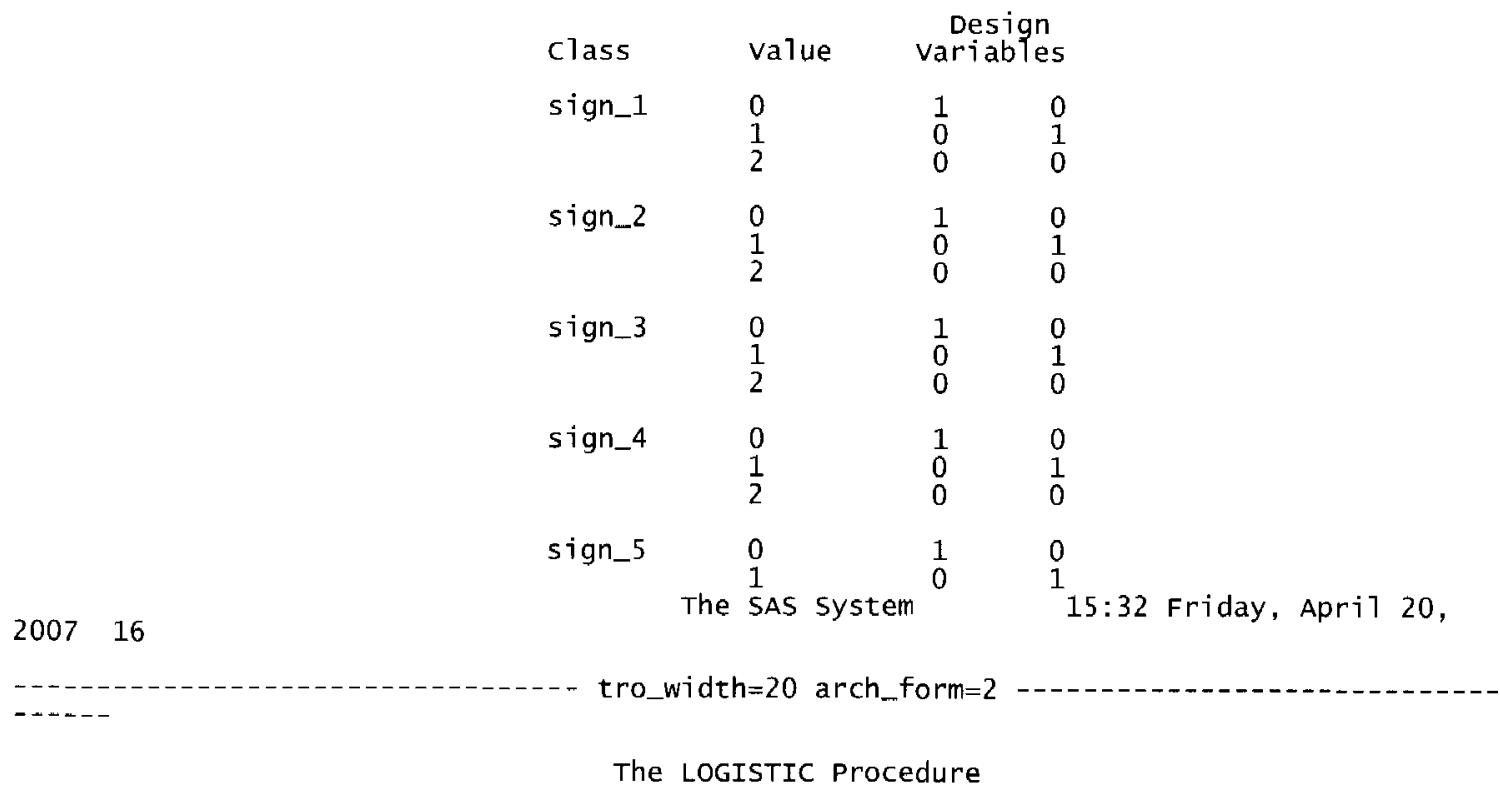




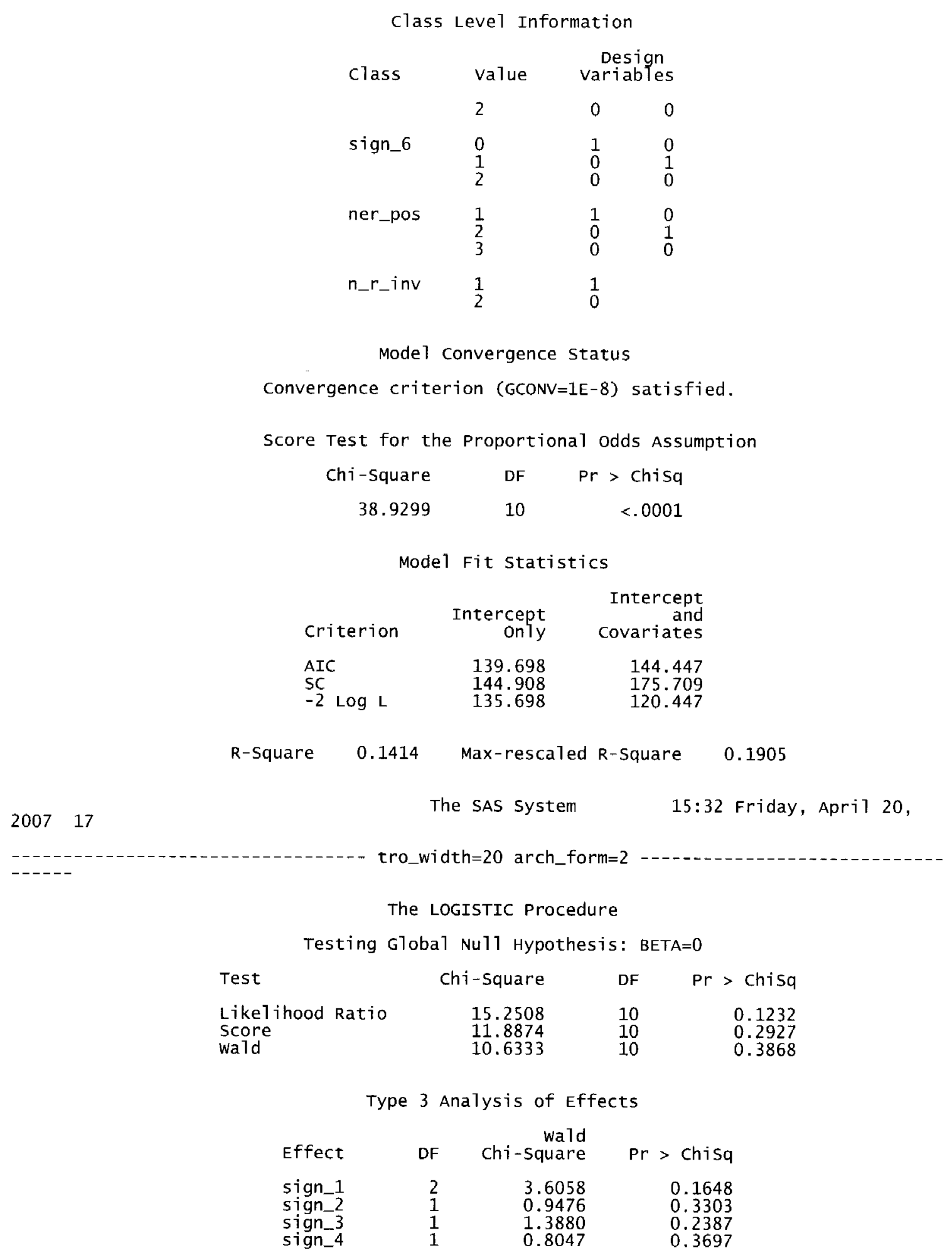




$\begin{array}{llll}\text { sign_5 } & 1 & 0.3730 & 0.5413 \\ \text { sign_6 } & 1 & 0.0111 & 0.9160 \\ \text { ner_pos } & 2 & 1.5519 & 0.4603 \\ \text { n_r_inv } & 1 & 3.4612 & 0.0628\end{array}$

NOTE: The following parameters have been set to 0 , since the variables are a linear combination of other variables as shown.

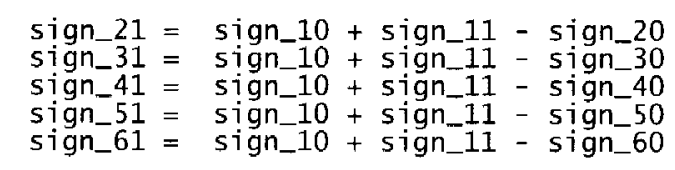

Analysis of Maximum Likelihood Estimates

\begin{tabular}{|c|c|c|c|c|c|}
\hline Parameter & DF & Estimate & $\begin{array}{l}\text { Standard } \\
\text { Error }\end{array}$ & $\begin{array}{r}\text { wald } \\
\text { Chi-square }\end{array}$ & $\mathrm{Pr}>$ Chisq \\
\hline $\begin{array}{ll}\text { Intercept } & 3 \\
\text { Intercept } & 2 \\
\text { sign_1 } & 0 \\
\text { sign_1 } & 1 \\
\text { sign_2 } & 0 \\
\text { sign_2 } & 1 \\
\text { sign_3 } & 0 \\
\text { sign_3 } & 1\end{array}$ & $\begin{array}{l}1 \\
1 \\
1 \\
1 \\
1 \\
0 \\
1\end{array}$ & $\begin{array}{r}-1.4894 \\
-0.6711 \\
-2.2924 \\
-3.3444 \\
0.7026 \\
0 \\
1.1157 \\
0\end{array}$ & $\begin{array}{l}0.6094 \\
0.5821 \\
2.0009 \\
1.9585 \\
0.7218 \\
0.9470\end{array}$ & $\begin{array}{l}5.9735 \\
1.3292 \\
1.3126 \\
2.9160 \\
0.9476 \\
1.3880\end{array}$ & $\begin{array}{l}0.0145 \\
0.2489 \\
0.2519 \\
0.0877 \\
0.3303 \\
0.2387\end{array}$ \\
\hline
\end{tabular}

$2007 \quad 18$

tro_width=20 arch_form=2

The LOGISTIC Procedure

Ana1ysis of Maximum Likelihood Estimates

\begin{tabular}{|c|c|c|c|c|c|c|}
\hline \multicolumn{2}{|c|}{ Parameter } & DF & Estimate & $\begin{array}{c}\text { Standard } \\
\text { Error }\end{array}$ & $\begin{array}{r}\text { wald } \\
\text { Chi-Square }\end{array}$ & $\mathrm{Pr}>$ Chisq \\
\hline sign_4 & 0 & 1 & 1.0785 & 1.2023 & 0.8047 & 0.3697 \\
\hline $\begin{array}{l}\text { sign_4 } \\
\text { sign_5 }\end{array}$ & $\frac{1}{0}$ & 1 & 0.5339 & 0.8742 & 0.3730 & 0.5413 \\
\hline sign_5 & 1 & 0 & & & & \\
\hline sign_6 & 0 & 1 & 0.0847 & 0.8025 & 0.0111 & 0.9160 \\
\hline $\begin{array}{l}\text { Sign_6 } \\
\text { ner_pos }\end{array}$ & $\begin{array}{l}1 \\
1\end{array}$ & $\begin{array}{l}0 \\
1\end{array}$ & $\begin{array}{r}0 \\
-0.6758\end{array}$ & 0.6174 & 1.1981 & 0.2737 \\
\hline ner pos & 2 & 1 & -0.0121 & 0.6708 & 0.0003 & 0.9856 \\
\hline$n_{-} r_{-} i n v$ & 1 & 1 & -2.1107 & 1.1345 & 3.4612 & 0.0628 \\
\hline
\end{tabular}

odds Ratio Estimațes

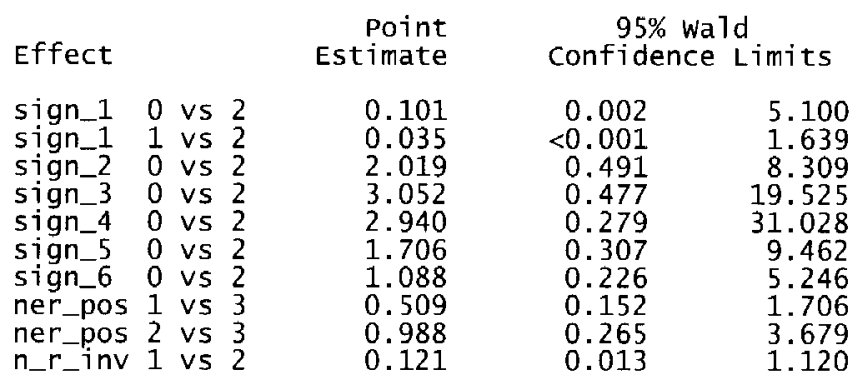

Association of Predicted Probabilities and observed Responses 


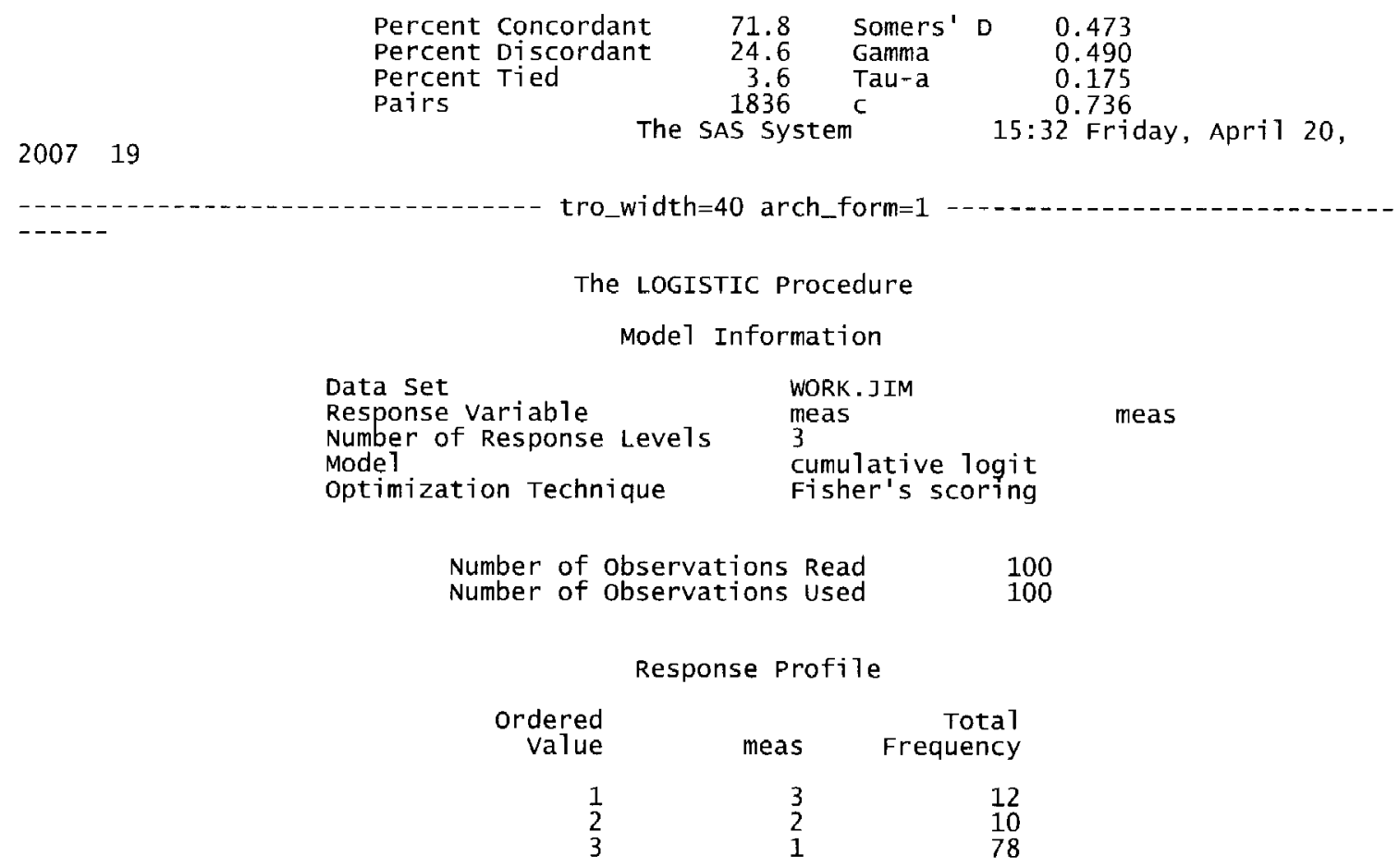

Probabilities modeled are cumulated over the lower ordered values.

Class Level Information

\begin{tabular}{llcl} 
class & value & \multicolumn{2}{c}{$\begin{array}{c}\text { Design } \\
\text { variables }\end{array}$} \\
sign_1 & 0 & 1 & 0 \\
& 1 & 0 & 1 \\
\multirow{2}{*}{ sign_2 } & 2 & 0 & 0 \\
& 0 & 1 & 0 \\
& 1 & 0 & 1 \\
sign_3 & 2 & 0 & 0 \\
& 0 & 1 & 0 \\
& 1 & 0 & 1 \\
& 2 & 0 & 0
\end{tabular}

$\begin{array}{llll}\operatorname{sign} 4 & 0 & 1 & 0 \\ & 1 & 0 & 1 \\ & 2 & 0 & 0\end{array}$

$2007 \quad 20$

$\begin{array}{llll}\text { sign_5 } & 0 & 1 & 0 \\ & 1 & 0 & 1\end{array}$

The SAS System 15:32 Friday, Apri1 20 .

tro_width=40 arch_form=1

The LOGISTIC Procedure

Class Level Information

Design 


\begin{tabular}{llcl} 
class & value & \multicolumn{2}{c}{ variables } \\
& 2 & 0 & 0 \\
sign_6 & 0 & 1 & 0 \\
& 1 & 0 & 1 \\
& 2 & 0 & 0 \\
ner_pos & 1 & 1 & 0 \\
& 2 & 0 & 1 \\
n_r_inv & 3 & 0 & 0 \\
& 1 & 1 &
\end{tabular}

Model Convergence Status

Quasi-complete separation of data points detected.

WARNING: The maximum likelihood estimate may not exist.

WARNING: The LOGISTIC procedure continues in spite of the above warning. Results shown are

based on the last maximum likelihood iteration. Validity of the model fit is questionable.

Score Test for the Proportional odds Assumption

Chi-square DF $\quad$ Pr $>$ Chisq

$32.3664 \quad 10 \quad 0.0003$

Model Fit statistics

$\begin{array}{lcc}\text { Criterion } & \begin{array}{r}\text { Intercept } \\ \text { Only }\end{array} & \begin{array}{c}\text { Intercept } \\ \text { and } \\ \text { Covariates }\end{array} \\ \text { AIC } & 139.698 & 140.481 \\ \text { SC } & 144.908 & 171.743 \\ -2 \text { Log L } & 135.698 & 116.481 \\ & \text { The SAS System } & 15: 32 \text { Friday, Apri1 20, }\end{array}$

200721

tro_width $=40$ arch_form=1

$-1--$

The LOGISTIC Procedure

WARNING: The validity of the model fit is questionable.

\begin{tabular}{lccr} 
R-Square & 0.1748 & Max-rescaled R-Square & 0.2354 \\
\multicolumn{4}{c}{ Testing Global Nu11 Hypothesis: BETA=0 } \\
Test & Chi-Square & DF & Pr > Chisq \\
Likelihood Ratio & 19.2169 & 10 & 0.0376 \\
Score & 14.7109 & 10 & 0.1430 \\
Wald & 9.5503 & 10 & 0.4808
\end{tabular}

Type 3 Analysis of Effects

$\begin{array}{lrrr}\text { Effect } & \text { DF } & \begin{array}{r}\text { wald } \\ \text { Chi-square }\end{array} & \mathrm{Pr}>\text { Chisq } \\ \text { sign_1 } & 2 & 0.6278 & 0.7306 \\ \text { sign_2 } & 1 & 0.9391 & 0.3325 \\ \text { sign_3 } & 1 & 0.0048 & 0.9446\end{array}$




$\begin{array}{llll}\text { sign_4 } & 1 & 1.2005 & 0.2732 \\ \text { sign_5 } & 1 & 0.1740 & 0.6766 \\ \text { sign_6 } & 1 & 0.3564 & 0.5505 \\ \text { ner_pos } & 2 & 1.1172 & 0.5720 \\ \text { n_r_inv } & 1 & 2.5038 & 0.1136\end{array}$

NOTE: The following parameters have been set to 0 , since the variables are a 7 inear combination of other variables as shown.

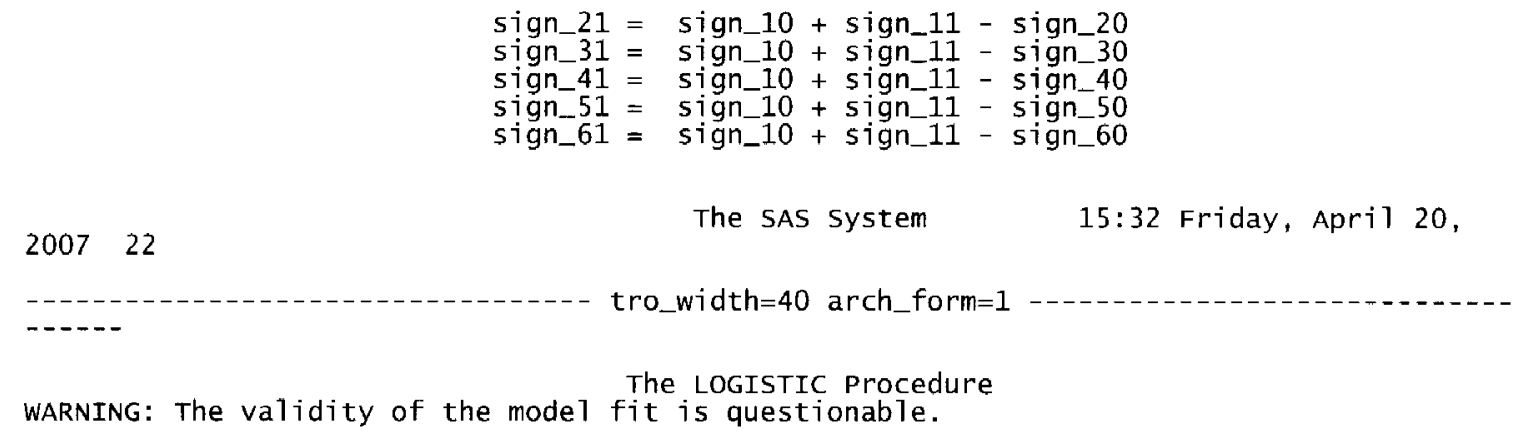

Analysis of Maximum Likelihood Estimates

\begin{tabular}{|c|c|c|c|c|c|c|}
\hline Parameter & & DF & Estimate & $\begin{array}{r}\text { Standard } \\
\text { Error }\end{array}$ & $\begin{array}{r}\text { wald } \\
\text { Chi-square }\end{array}$ & $\mathrm{Pr}>$ Chisq \\
\hline Intercept & 3 & 1 & -0.7356 & 0.8466 & 0.7549 & 0.3849 \\
\hline Intercept & 2 & $\begin{array}{l}1 \\
1\end{array}$ & 0.0936 & 0.8400 & 0.0124 & 0.9112 \\
\hline sign_1 & $\overline{0}$ & $\overline{1}$ & -14.3493 & 165.6 & 0.0075 & 0.9309 \\
\hline sign_1 & 1 & 1 & -14.9451 & 165.6 & 0.0081 & 0.9281 \\
\hline sịgn_2 & 0 & 1 & 0.5901 & 0.6090 & 0.9391 & 0.3325 \\
\hline sign_2 & 1 & 0 & & & $0 \cap 0$ & ? \\
\hline sign-3 & 0 & 1 & 11.5055 & 165.6 & 0.0048 & 0.9446 \\
\hline $\begin{array}{l}\text { sign_3 } \\
\text { sign_4 }\end{array}$ & $\begin{array}{l}1 \\
0\end{array}$ & $\begin{array}{l}0 \\
1\end{array}$ & $\begin{array}{r}0 \\
1.3292\end{array}$ & 1.2131 & 1.2005 & 0.2732 \\
\hline sign_4 & 1 & 0 & & & & \\
\hline signn_5 & 0 & 1 & 0.3386 & 0.8118 & 0.1740 & 0.6766 \\
\hline sign_5 & 1 & 0 & $\begin{array}{r}0 \\
05157^{2}\end{array}$ & $086>9$ & 03564 & 055 \\
\hline sign_6 & $\begin{array}{l}0 \\
1\end{array}$ & $\begin{array}{l}1 \\
0\end{array}$ & $\begin{array}{r}0.3132 \\
0\end{array}$ & $0.86<9$ & 0.3504 & 0.5 \\
\hline ner_pos & 1 & 1 & -0.4887 & 0.6271 & 0.6072 & 0.4359 \\
\hline $\begin{array}{l}\text { ner_pos } \\
n \text { r_inv }\end{array}$ & $\begin{array}{l}2 \\
1\end{array}$ & $\begin{array}{l}1 \\
1\end{array}$ & $\begin{array}{r}0.17 \\
-1.78\end{array}$ & $\begin{array}{l}0.7180 \\
1.1274\end{array}$ & $\begin{array}{l}0.0612 \\
2.5038\end{array}$ & $\begin{array}{l}0.8046 \\
0.1136\end{array}$ \\
\hline & & & & & & \\
\hline
\end{tabular}

Odds Ratio Estimates

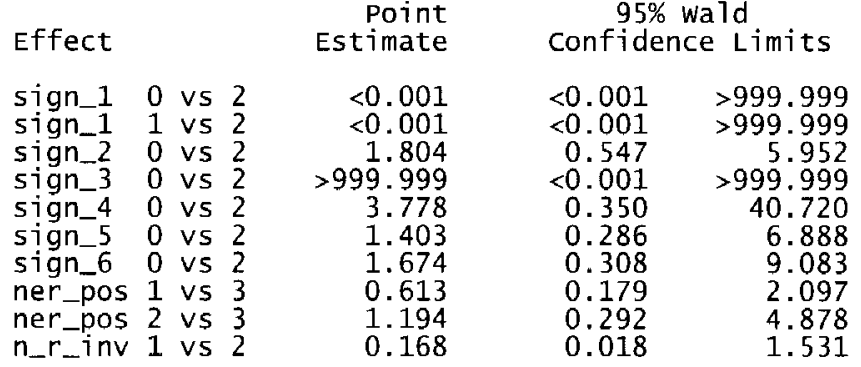




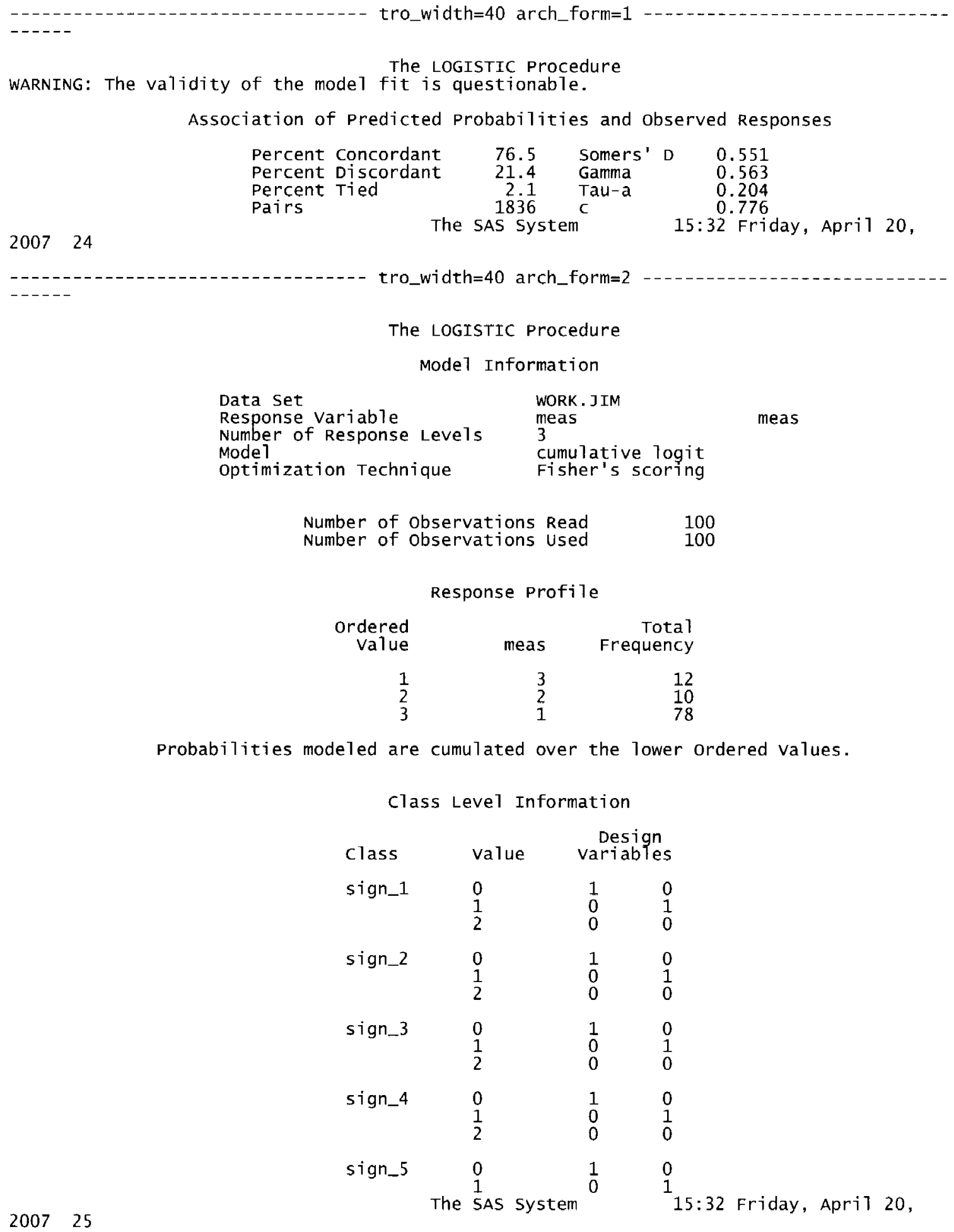




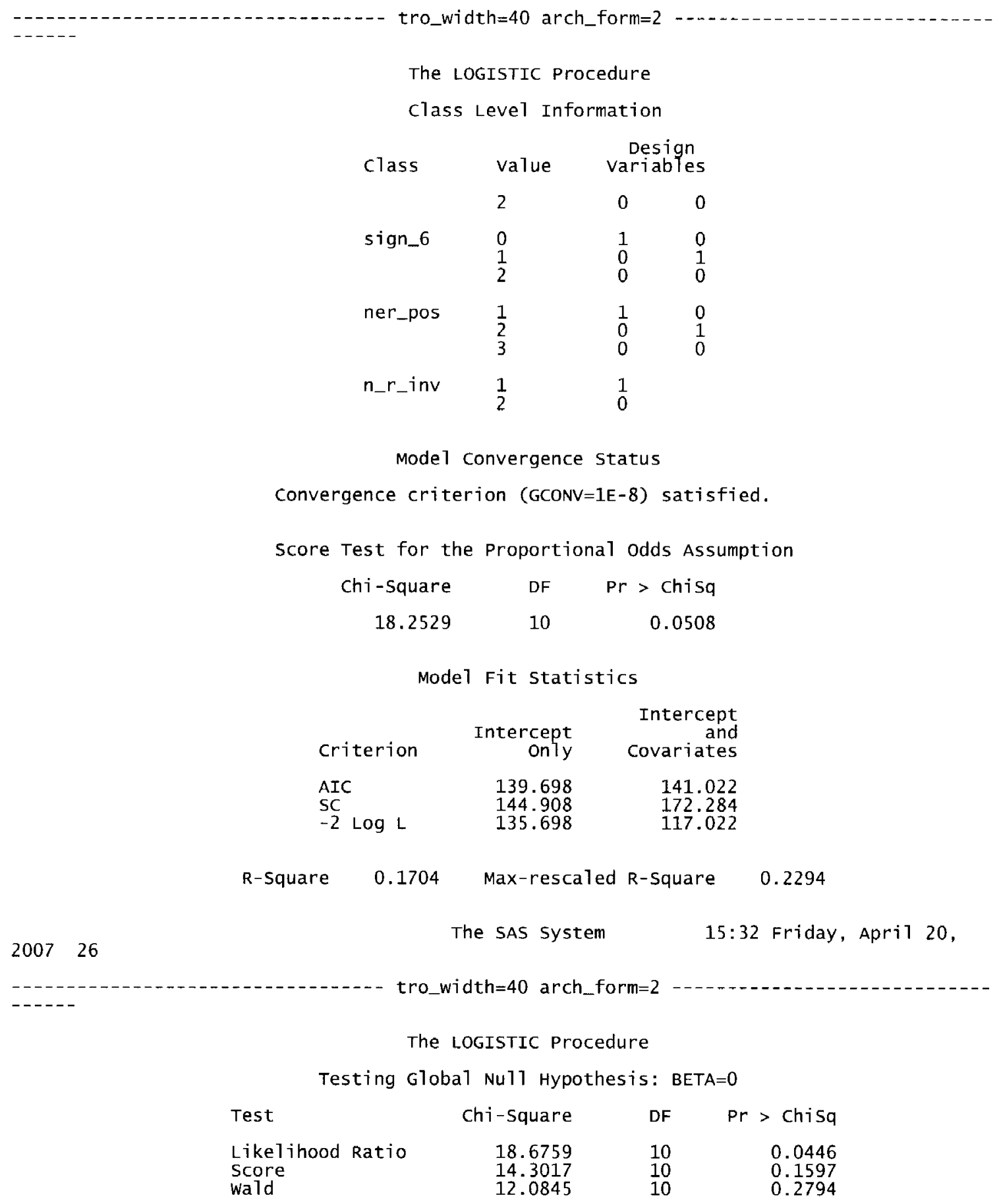

Type 3 Analysis of Effects

Effect $\quad$ DF Chi-square $\quad \mathrm{Pr}>$ Chisq 


$\begin{array}{llll}\text { sign_1 } & 2 & 1.1903 & 0.5515 \\ \text { sign_2 } & 1 & 0.0301 & 0.8623 \\ \text { sign_3 } & 1 & 3.1705 & 0.0750 \\ \text { sign_4 } & 1 & 2.1832 & 0.1395 \\ \text { sign_5 } & 1 & 1.8391 & 0.1751 \\ \text { sign_6 } & 1 & 1.0282 & 0.3106 \\ \text { ner_pos } & 2 & 1.1471 & 0.5635 \\ \text { n_r_inv } & 1 & 3.2064 & 0.0733\end{array}$

NOTE: The following parameters have been set to 0 , since the variables are a linear combination of other variables as shown.

$$
\begin{aligned}
& \text { sign_21 }=\text { sign_10+sign_11-sign_20 } \\
& \text { sign_31 }=\text { sign_10+sign_11-sign_30 } \\
& \text { sign_41 }=\text { sign_10+sign_11-sign_40 } \\
& \text { sign_51 }=\text { sign_10+sign_11-sign_50 } \\
& \text { sign_61 }=\text { sign_10+ sign_11 - sign_60 }
\end{aligned}
$$

Analysis of Maximum Likelihood Estimates

$\begin{array}{ll} & \\ \text { Parameter } & \\ \text { Intercept } & 3 \\ \text { Intercept } & 2 \\ \text { sign_1 } & 0 \\ \text { sign_1 } & 1 \\ \text { sign_2 } & 0 \\ \text { sign_2 } & 1 \\ \text { sign_3 } & 0 \\ \text { sign_3 } & 1\end{array}$

$2007 \quad 27$

$\begin{array}{crr}\text { DF } & \text { Estimate } & \begin{array}{r}\text { Standard } \\ \text { Error }\end{array} \\ 1 & -2.1274 & 0.6688 \\ 1 & -1.2691 & 0.6293 \\ 1 & -2.2617 & 2.6638 \\ 1 & -2.1418 & 1.9724 \\ 1 & -0.1200 & 0.6914 \\ 0 & 0 & \\ 1 & -1.8663 & 1.0481 \\ 0 & 0 & \\ & \text { The SAS System }\end{array}$

\begin{tabular}{|c|c|c|c|c|c|c|}
\hline \multicolumn{2}{|l|}{ Parameter } & DF & Estimate & $\begin{array}{r}\text { Standard } \\
\text { Error }\end{array}$ & $\begin{array}{r}\text { wald } \\
\text { Chi-square }\end{array}$ & $\mathrm{Pr}>$ chisq \\
\hline $\operatorname{sign}_{\operatorname{sign} 4} 4$ & 0 & $\frac{1}{0}$ & 1.8417 & 1.2465 & 2.1832 & 0.1395 \\
\hline $\begin{array}{l}\text { sign_5 } \\
\text { sign-5 }\end{array}$ & $\begin{array}{l}0 \\
1\end{array}$ & $\begin{array}{l}1 \\
0\end{array}$ & 1.9917 & $1.468 \dot{7}$ & 1.8391 & 0.1751 \\
\hline $\begin{array}{l}\text { sign_6 } \\
\text { sign_6 }\end{array}$ & $\begin{array}{l}0 \\
1\end{array}$ & $\begin{array}{l}1 \\
0\end{array}$ & $\begin{array}{r}1.2986 \\
0\end{array}$ & 1.2807 & 1.0282 & 0.3106 \\
\hline $\begin{array}{l}\text { ner_pos } \\
\text { ner_pos } \\
\text { n_r_inv }\end{array}$ & $\begin{array}{l}1 \\
2 \\
1\end{array}$ & $\begin{array}{l}1 \\
1 \\
1\end{array}$ & $\begin{array}{r}-0.1754 \\
0.5441 \\
-2.0939\end{array}$ & $\begin{array}{l}0.6260 \\
0.7182 \\
1.1694\end{array}$ & $\begin{array}{l}0.0785 \\
0.5739 \\
3.2064\end{array}$ & $\begin{array}{l}0.7793 \\
0.4487 \\
0.0733\end{array}$ \\
\hline
\end{tabular}

$$
\begin{aligned}
& \begin{array}{r}
\text { wald } \\
\text { chi-square }
\end{array} \\
& \mathrm{Pr}>\text { ChiSq } \\
& 10.1171 \\
& \begin{array}{ll}
4.0672 & 0.0437
\end{array} \\
& 0.7209 \quad 0.3958 \\
& 1.1792 \\
& 0.0301 \quad 0.8623 \\
& \text { 3.1705 } 0.0750 \\
& \text { 15:32 Friday, Apri } 20 \text {, }
\end{aligned}
$$

tro_width=40 arch_form $=2$

The LOGISTIC Procedure

Analysis of Maximum Likelihood Estimates

Odds Ratio Estimates

Effect

sign_1 0 vs 2

sign 1 1 vs

$\operatorname{sign} 2 \quad 0$ vs 2

sign_3 0 vs 2

sign_4 0 vs 2

sign 5 v 0 s 2

sign_6 0 vs 2

ner_pos 1 vs 3

ner_pos 2 vs 3

Patio Estimates

Point $\quad 95 \%$ wald Estimate Confidence Limits

$\begin{array}{lrr}0.104 & <0.001 & 19.281 \\ 0.117 & 0.002 & 5.607 \\ 0.887 & 0.229 & 3.439 \\ 0.155 & 0.020 & 1.207 \\ 6.308 & 0.548 & 72.587 \\ 7.328 & 0.412 & 130.346 \\ 3.664 & 0.298 & 45.097 \\ 0.839 & 0.246 & 2.862 \\ 1.723 & 0.422 & 7.041\end{array}$



n_r_inv 1 vs 2
0.123
0.012
1.219

Association of Predicted Probabilities and observed Responses

$\begin{array}{lrll}\text { Percent concordant } & 76.5 & \text { Somers' D } & 0.570 \\ \text { Percent Discordant } & 19.4 & \text { Gamma } & 0.595 \\ \text { Percent Tied } & 4.1 & \text { Tau-a } & 0.212 \\ \text { Pairs } & 1836 & \text { C } & 0.785\end{array}$




\section{Reliability--TWO RATERS-- SIGN 1 ORIGINAL}

Notes

\section{[Dataset1] INTER-RATER RELIABILITY FOR TWO RATERS}

Scale: ALL VARIABLES

Case Processing Summary

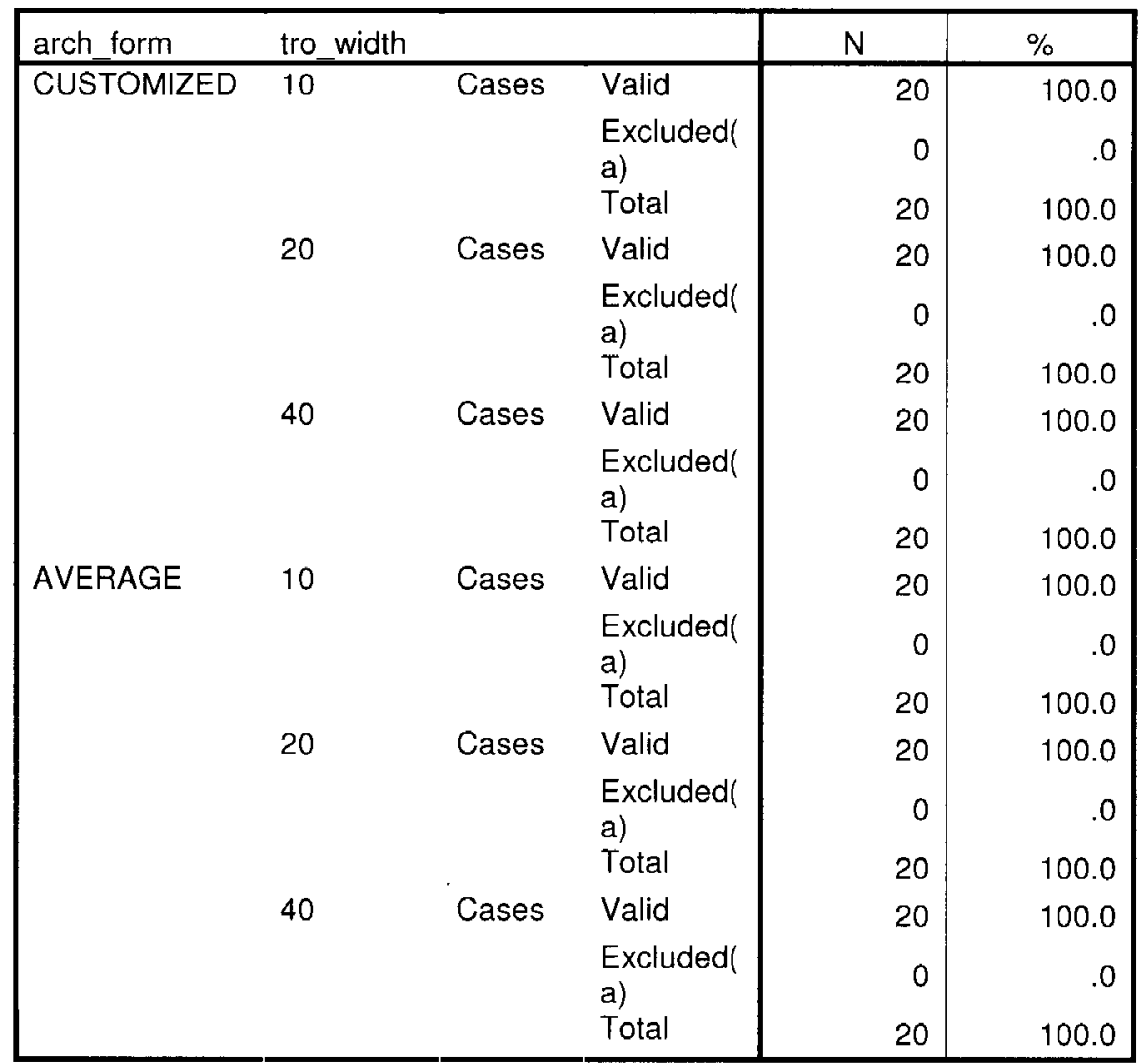

a Listwise deletion based on all variables in the procedure. 
Reliability Statistics

\begin{tabular}{|ll|r|r|}
\hline arch_form & tro_width & $\begin{array}{c}\text { Cronbach's } \\
\text { Alpha }\end{array}$ & N of ltems \\
\hline CUSTOMIZED & 10 & .457 & 2 \\
& 20 & .378 & 2 \\
& 40 & .061 & 2 \\
AVERAGE & 10 & .858 & 2 \\
& 20 & .608 & 2 \\
& 40 & .482 & 2 \\
\hline
\end{tabular}

Intraclass Correlation Coefficient

\begin{tabular}{|c|c|c|c|c|c|c|c|c|c|}
\hline \multirow[b]{2}{*}{ arch_form } & \multirow[b]{2}{*}{ tro_width } & & \multirow[b]{2}{*}{$\begin{array}{c}\text { Intraclass } \\
\text { Correlation(a) }\end{array}$} & \multicolumn{2}{|c|}{$\begin{array}{l}95 \% \text { Confidence } \\
\text { Interval }\end{array}$} & \multicolumn{4}{|c|}{ F Test with True Value 0} \\
\hline & & & & $\begin{array}{l}\text { Upper } \\
\text { Bound }\end{array}$ & Value & df1 & df2 & Sig & $\begin{array}{l}\text { Lower } \\
\text { Bound }\end{array}$ \\
\hline \multirow[t]{6}{*}{ CUSTOMIZED } & 10 & $\begin{array}{l}\text { Single } \\
\text { Measures }\end{array}$ & 296 (b) & -.157 & .646 & 1.840 & 19 & 19 & .096 \\
\hline & & $\begin{array}{l}\text { Average } \\
\text { Measures }\end{array}$ & $.457(\mathrm{c})$ & -.373 & .785 & 1.840 & 19 & 19 & .096 \\
\hline & 20 & $\begin{array}{l}\text { Single } \\
\text { Measures }\end{array}$ & $.233(b)$ & -.222 & .605 & 1.608 & 19 & 19 & .155 \\
\hline & & $\begin{array}{l}\text { Average } \\
\text { Measures }\end{array}$ & $.378(c)$ & -.571 & .754 & 1.608 & 19 & 19 & .155 \\
\hline & 40 & $\begin{array}{l}\text { Single } \\
\text { Measures }\end{array}$ & $.031(b)$ & -.407 & 458 & 1.065 & 19 & 19 & .446 \\
\hline & & $\begin{array}{l}\text { Average } \\
\text { Measures }\end{array}$ & $.061(\mathrm{c})$ & -1.373 & .628 & 1.065 & 19 & 19 & .446 \\
\hline \multirow[t]{6}{*}{ AVERAGE } & 10 & $\begin{array}{l}\text { Single } \\
\text { Measures }\end{array}$ & $.751(b)$ & .472 & .894 & 7.043 & 19 & 19 & .000 \\
\hline & & $\begin{array}{l}\text { Average } \\
\text { Measures }\end{array}$ & $.858(\mathrm{c})$ & .641 & .944 & 7.043 & 19 & 19 & .000 \\
\hline & 20 & $\begin{array}{l}\text { Single } \\
\text { Measures }\end{array}$ & $.437(b)$ & .005 & .731 & 2.550 & 19 & 19 & .024 \\
\hline & & $\begin{array}{l}\text { Average } \\
\text { Measures }\end{array}$ & $.608(c)$ & .009 & .845 & 2.550 & 19 & 19 & .024 \\
\hline & 40 & $\begin{array}{l}\text { Single } \\
\text { Measures }\end{array}$ & $.317(\mathrm{~b})$ & -.134 & .659 & 1.929 & 19 & 19 & .08 \\
\hline & & $\begin{array}{l}\text { Average } \\
\text { Measures }\end{array}$ & $.482(c)$ & -.310 & .795 & 1.929 & 19 & 19 & .081 \\
\hline
\end{tabular}

Two-way mixed effects model where people effects are random and measures effects are fixed.

a Type $\mathrm{C}$ intraclass correlation coefficients using a consistency definition-the between-measure variance is excluded from the denominator variance.

$b$ The estimator is the same, whether the interaction effect is present or not.

c This estimate is computed assuming the interaction effect is absent, because it is not estimable otherwise.

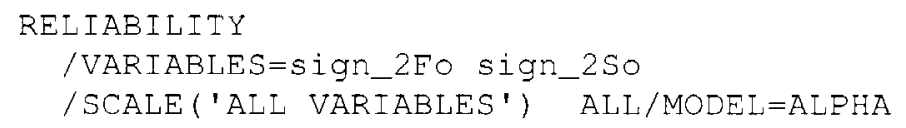


/ICC=MODEL (MIXED) TYPE (CONSISTENCY) CIN=95 TESTVAL=0 .

\section{Reliability--TWO RATERS--SIGN 2 ORIGINAL}

Notes

taset 1$]$

\section{Scale: ALL VARIABLES}

Case Processing Summary

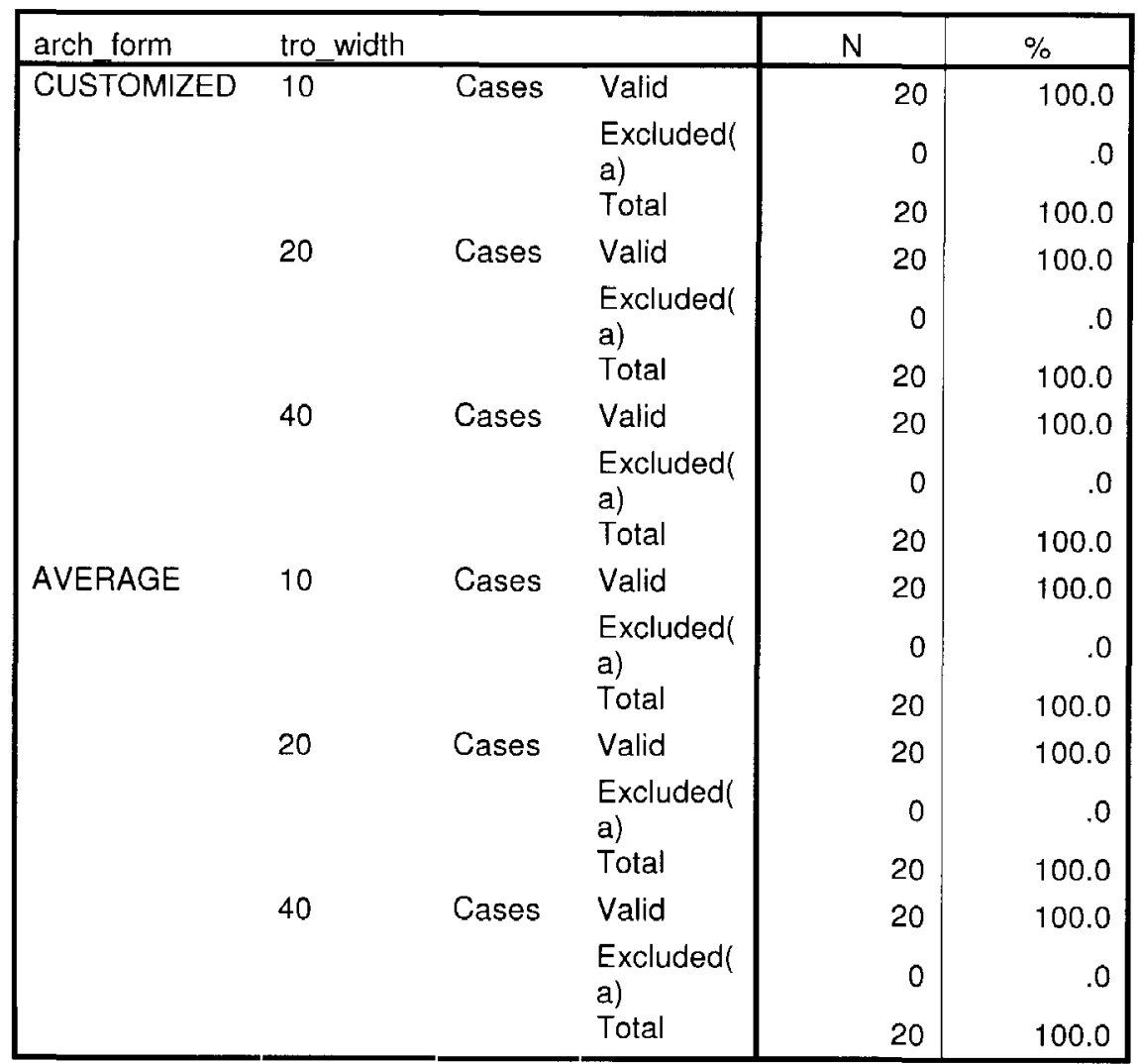

a Listwise deletion based on all variables in the procedure.

\section{Reliability Statistics}

\begin{tabular}{|ll|r|r|}
\hline arch form & tro width & $\begin{array}{c}\text { Cronbach's } \\
\text { Alpha }\end{array}$ & N of Items \\
\hline CUSTOMIZED & 10 & .640 & 2 \\
\hline
\end{tabular}




\begin{tabular}{|ll|l|l|} 
& 20 & .711 & 2 \\
AVERAGE & 40 & .588 & 2 \\
& 10 & .965 & 2 \\
& 20 & .785 & 2 \\
& 40 & .602 & 2 \\
\hline
\end{tabular}

Intraclass Correlation Coefficient

\begin{tabular}{|c|c|c|c|c|c|c|c|c|c|}
\hline \multirow[b]{2}{*}{ arch_form } & \multirow[b]{2}{*}{ tro_width } & & \multirow[b]{2}{*}{$\begin{array}{c}\text { Intraclass } \\
\text { Correlation(a) }\end{array}$} & \multicolumn{2}{|c|}{$\begin{array}{l}\text { 95\% Confidence } \\
\text { Interval }\end{array}$} & \multicolumn{4}{|c|}{ F Test with True Value 0} \\
\hline & & & & $\begin{array}{l}\text { Upper } \\
\text { Bound }\end{array}$ & Value & df1 & $\mathrm{df} 2$ & Sig & $\begin{array}{l}\text { Lower } \\
\text { Bound }\end{array}$ \\
\hline \multirow[t]{6}{*}{ CUSTOMIZED } & 10 & $\begin{array}{l}\text { Single } \\
\text { Measures }\end{array}$ & $.471(\mathrm{~b})$ & .047 & .751 & 2.778 & 19 & 19 & .016 \\
\hline & & $\begin{array}{l}\text { Average } \\
\text { Measures }\end{array}$ & $.640(c)$ & .090 & .858 & 2.778 & 19 & 19 & .016 \\
\hline & 20 & $\begin{array}{l}\text { Single } \\
\text { Measures }\end{array}$ & $.552(\mathrm{~b})$ & .156 & .795 & 3.462 & 19 & 19 & .005 \\
\hline & & $\begin{array}{l}\text { Average } \\
\text { Measures }\end{array}$ & $.711(\mathrm{c})$ & .270 & .886 & 3.462 & 19 & 19 & .005 \\
\hline & 40 & $\begin{array}{l}\text { Single } \\
\text { Measures }\end{array}$ & $.416(\mathrm{~b})$ & -.021 & .719 & 2.425 & 19 & 19 & .030 \\
\hline & & $\begin{array}{l}\text { Average } \\
\text { Measures }\end{array}$ & $.588(c)$ & -.042 & .837 & 2.425 & 19 & 19 & .030 \\
\hline \multirow[t]{6}{*}{ AVERAGE } & 10 & $\begin{array}{l}\text { Single } \\
\text { Measures }\end{array}$ & $.932(b)$ & .837 & .973 & 28.500 & 19 & 19 & .000 \\
\hline & & $\begin{array}{l}\text { Average } \\
\text { Measures }\end{array}$ & $.965(c)$ & .911 & .986 & 28.500 & 19 & 19 & .000 \\
\hline & 20 & $\begin{array}{l}\text { Single } \\
\text { Measures }\end{array}$ & $.646(\mathrm{~b})$ & 296 & .843 & 4.649 & 19 & 19 & .001 \\
\hline & & $\begin{array}{l}\text { Average } \\
\text { Measures }\end{array}$ & $.785(\mathrm{c})$ & .457 & .915 & 4.649 & 19 & 19 & .001 \\
\hline & 40 & $\begin{array}{l}\text { Single } \\
\text { Measures }\end{array}$ & $.431(b)$ & -.003 & .728 & 2.513 & 19 & 19 & .026 \\
\hline & & $\begin{array}{l}\text { Average } \\
\text { Measures }\end{array}$ & $.602(c)$ & -.005 & .842 & 2.513 & 19 & 19 & .026 \\
\hline
\end{tabular}

Two-way mixed effects model where people effects are random and measures effects are fixed.

a Type $\mathrm{C}$ intraclass correlation coefficients using a consistency definition-the between-measure variance is excluded from the denominator variance.

$b$ The estimator is the same, whether the interaction effect is present or not.

c This estimate is computed assuming the interaction effect is absent, because it is not estimable otherwise.

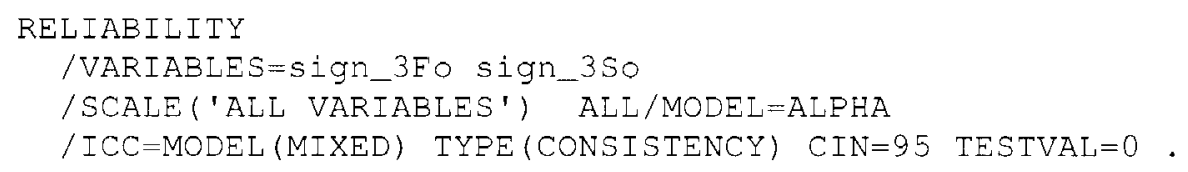

\section{Reliability--TWO RATERS--SIGN 3 ORIGINAL}


Notes

[Dataset 1]

\section{Scale: ALL VARIABLES}

Case Processing Summary

\begin{tabular}{|c|c|c|c|c|c|}
\hline arch form & tro width & & & $\mathrm{N}$ & $\%$ \\
\hline \multirow[t]{9}{*}{ CUSTOMIZED } & 10 & Cases & Valid & 20 & 100.0 \\
\hline & & & $\begin{array}{l}\text { Excluded( } \\
\text { a) }\end{array}$ & 0 & .0 \\
\hline & & & Total & 20 & 100.0 \\
\hline & 20 & Cases & Valid & 20 & 100.0 \\
\hline & & & $\begin{array}{l}\text { Excluded( } \\
\text { a) }\end{array}$ & 0 & .0 \\
\hline & & & Total & 20 & 100.0 \\
\hline & 40 & Cases & Valid & 20 & 100.0 \\
\hline & & & $\begin{array}{l}\text { Excluded( } \\
\text { a) }\end{array}$ & 0 & .0 \\
\hline & & & Total & 20 & 100.0 \\
\hline \multirow[t]{9}{*}{ AVERAGE } & 10 & Cases & Valid & 20 & 100.0 \\
\hline & & & $\begin{array}{l}\text { Excluded( } \\
\text { a) }\end{array}$ & 0 & .0 \\
\hline & & & Total & 20 & 100.0 \\
\hline & 20 & Cases & Valid & 20 & 100.0 \\
\hline & & & $\begin{array}{l}\text { Excluded( } \\
\text { a) }\end{array}$ & 0 & .0 \\
\hline & & & Total & 20 & 100.0 \\
\hline & 40 & Cases & Valid & 20 & 100.0 \\
\hline & & & $\begin{array}{l}\text { Excluded( } \\
\text { a) }\end{array}$ & 0 & .0 \\
\hline & & & Total & 20 & 100.0 \\
\hline
\end{tabular}

a Listwise deletion based on all variables in the procedure.

\section{Reliability Statistics}

\begin{tabular}{|ll|r|r|}
\hline arch form & tro_width & $\begin{array}{c}\text { Cronbach's } \\
\text { Alpha(a) }\end{array}$ & N of Items \\
\hline CUSTOMIZED & 10 & .387 & 2 \\
& 20 & -.115 & 2 \\
& 40 & .443 & 2 \\
AVERAGE & 10 & .847 & 2 \\
& 20 & .717 & 2
\end{tabular}


\begin{tabular}{l|l|l|}
40 & .576 & 2 \\
\hline
\end{tabular} assumptions. You may want to check item codings.

Intraclass Correlation Coefficient

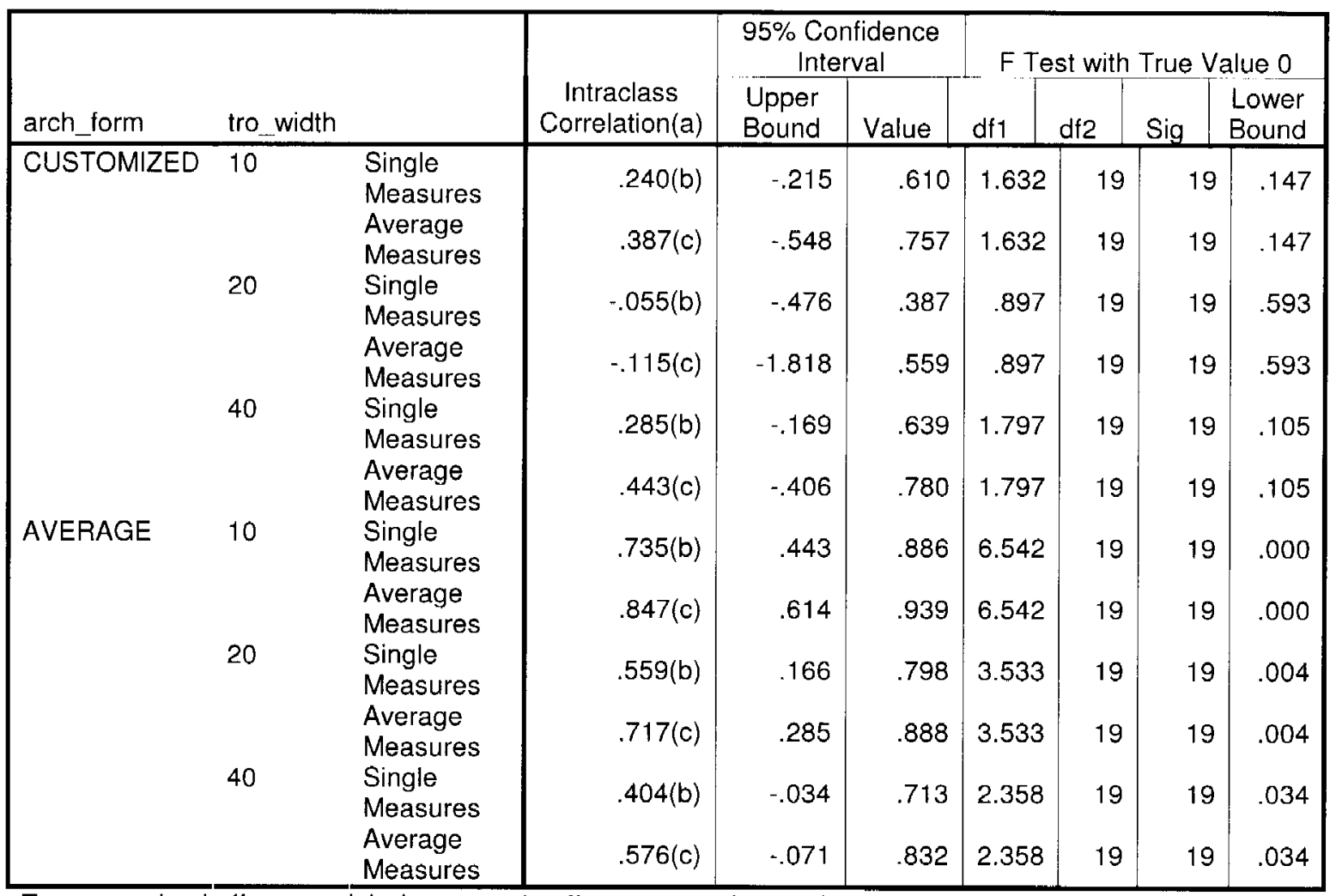

Two-way mixed effects model where people effects are random and measures effects are fixed.

a Type $\mathrm{C}$ intraclass correlation coefficients using a consistency definition-the between-measure variance is excluded from the denominator variance.

b The estimator is the same, whether the interaction effect is present or not.

c This estimate is computed assuming the interaction effect is absent, because it is not estimable otherwise.

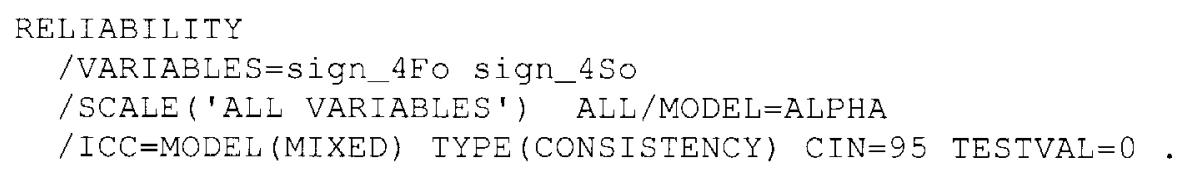

Reliability--TWO RATERS--SIGN 4 ORIGINAL

\section{Notes}


[DataSet 1]

Scale: ALL VARIABLES

Case Processing Summary

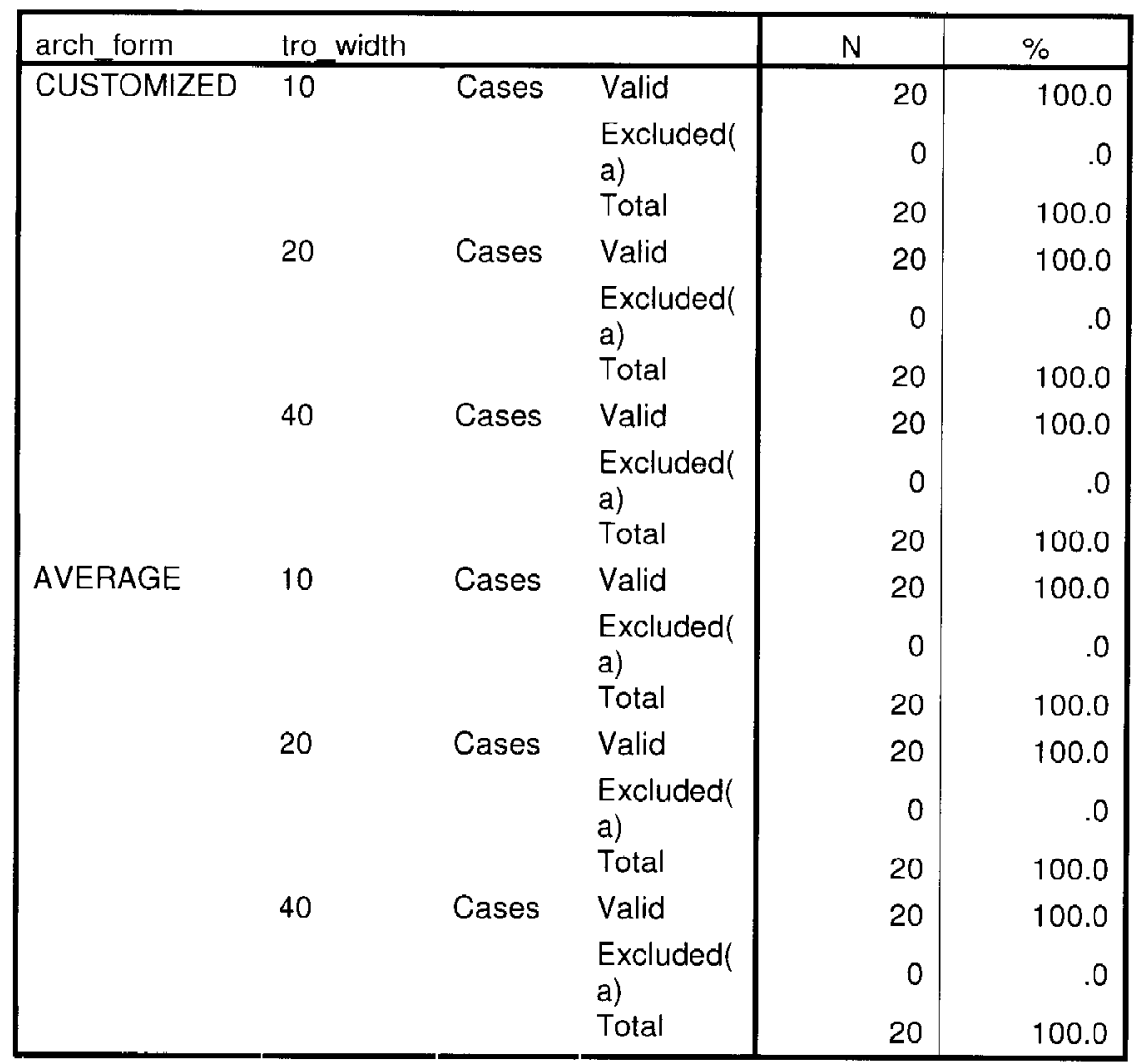

a Listwise deletion based on all variables in the procedure.

Reliability Statistics

\begin{tabular}{|ll|r|r|}
\hline arch form & tro width & $\begin{array}{c}\text { Cronbach's } \\
\text { Alpha(a) }\end{array}$ & N of Items \\
\hline CUSTOMIZED & 10 & .000 & 2 \\
& 20 & -.353 & 2 \\
& 40 & .497 & 2 \\
AVERAGE & 10 & .894 & 2 \\
& 20 & .648 & 2 \\
& 40 & .276 & 2 \\
\hline
\end{tabular}

a The value is negative due to a negative average covariance among items. This violates reliability model assumptions. You may want to check item codings. 
Intraclass Correlation Coefficient

\begin{tabular}{|c|c|c|c|c|c|c|c|c|c|}
\hline \multirow[b]{2}{*}{ arch form } & \multirow[b]{2}{*}{ tro_width } & & \multirow[b]{2}{*}{$\begin{array}{c}\text { Intraclass } \\
\text { Correlation(a) }\end{array}$} & \multicolumn{2}{|c|}{$\begin{array}{l}95 \% \text { Confidence } \\
\text { Interval }\end{array}$} & \multicolumn{4}{|c|}{ F Test with True Value 0} \\
\hline & & & & $\begin{array}{l}\text { Upper } \\
\text { Bound }\end{array}$ & Value & $\mathrm{df} 1$ & $\mathrm{df} 2$ & Sig & $\begin{array}{l}\text { Lower } \\
\text { Bound }\end{array}$ \\
\hline \multirow[t]{6}{*}{ CUSTOMIZED } & 10 & $\begin{array}{l}\text { Single } \\
\text { Measures }\end{array}$ & $.000(\mathrm{~b})$ & -.433 & .433 & 1.000 & 19 & 19 & .500 \\
\hline & & $\begin{array}{l}\text { Average } \\
\text { Measures }\end{array}$ & $.000(\mathrm{c})$ & -1.526 & .604 & 1.000 & 19 & 19 & .500 \\
\hline & 20 & $\begin{array}{l}\text { Single } \\
\text { Measures }\end{array}$ & $-.150(b)$ & -.547 & .302 & .739 & 19 & 19 & .742 \\
\hline & & $\begin{array}{l}\text { Average } \\
\text { Measures }\end{array}$ & $-.353(c)$ & -2.418 & .464 & .739 & 19 & 19 & .742 \\
\hline & 40 & $\begin{array}{l}\text { Single } \\
\text { Measures }\end{array}$ & $.331(b)$ & -.119 & .668 & 1.988 & 19 & 19 & .072 \\
\hline & & $\begin{array}{l}\text { Average } \\
\text { Measures }\end{array}$ & $.497(\mathrm{c})$ & -.271 & .801 & 1.988 & 19 & 19 & .072 \\
\hline \multirow[t]{6}{*}{ AVERAGE } & 10 & $\begin{array}{l}\text { Single } \\
\text { Measures }\end{array}$ & $.809(b)$ & .578 & .920 & 9.460 & 19 & 19 & .000 \\
\hline & & $\begin{array}{l}\text { Average } \\
\text { Measures }\end{array}$ & $.894(\mathrm{c})$ & .733 & .958 & 9.460 & 19 & 19 & .000 \\
\hline & 20 & $\begin{array}{l}\text { Single } \\
\text { Measures }\end{array}$ & $.479(\mathrm{~b})$ & .059 & .756 & 2.842 & 19 & 19 & .014 \\
\hline & & $\begin{array}{l}\text { Average } \\
\text { Measures }\end{array}$ & $.648(\mathrm{c})$ & .111 & .861 & 2.842 & 19 & 19 & .014 \\
\hline & 40 & $\begin{array}{l}\text { Single } \\
\text { Measures }\end{array}$ & $.160(b)$ & -.293 & .554 & 1.381 & 19 & 19 & .244 \\
\hline & & $\begin{array}{l}\text { Average } \\
\text { Measures }\end{array}$ & $.276(\mathrm{c})$ & -.829 & .713 & 1.381 & 19 & 19 & .244 \\
\hline
\end{tabular}

Two-way mixed effects model where people effects are random and measures effects are fixed.

a Type $C$ intraclass correlation coefficients using a consistency definition-the between-measure variance is excluded from the denominator variance.

b The estimator is the same, whether the interaction effect is present or not.

c This estimate is computed assuming the interaction effect is absent, because it is not estimable otherwise.

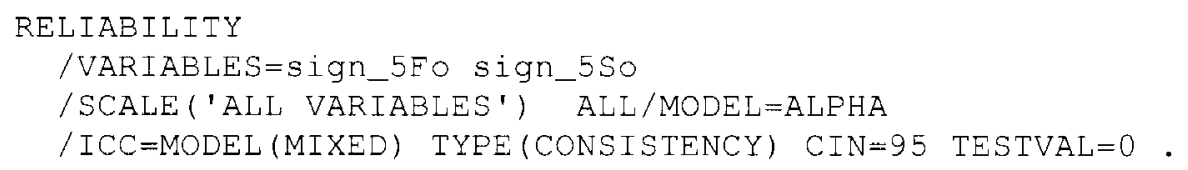

\section{Reliability--TWO RATERS--SIGN 5 ORIGINAL}

\section{Notes}

[Dataset1] 


\section{Scale: ALL VARIABLES}

Case Processing Summary

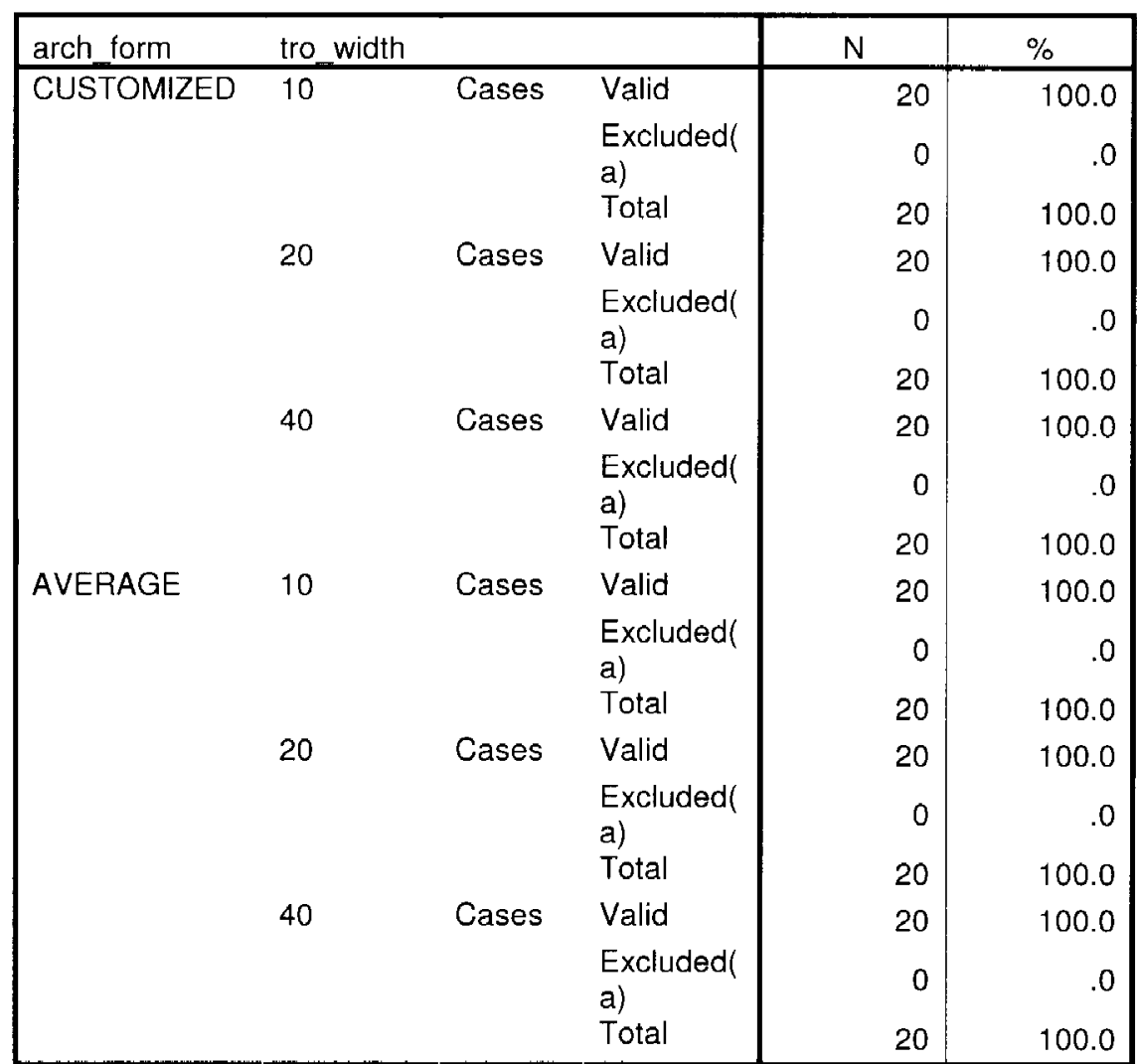

a Listwise deletion based on all variables in the procedure.

\section{Reliability Statistics}

\begin{tabular}{|ll|r|r|}
\hline arch_form & tro width & $\begin{array}{c}\text { Cronbach's } \\
\text { Alpha }\end{array}$ & N of Items \\
\hline CUSTOMIZED & 10 & .700 & 2 \\
& 20 & .580 & 2 \\
& 40 & .550 & 2 \\
AVERAGE & 10 & .968 & 2 \\
& 20 & .587 & 2 \\
& 40 & .560 & 2 \\
\hline
\end{tabular}

Intraclass Correlation Coefficient 


\begin{tabular}{|c|c|c|c|c|c|c|c|c|c|}
\hline \multirow[b]{2}{*}{ arch_form } & \multirow[b]{2}{*}{ tro_width } & & \multirow[b]{2}{*}{$\begin{array}{c}\text { Intraclass } \\
\text { Correlation(a) }\end{array}$} & \multicolumn{2}{|c|}{$\begin{array}{l}95 \% \text { Confidence } \\
\text { Interval }\end{array}$} & \multicolumn{4}{|c|}{ F Test with True Value 0} \\
\hline & & & & $\begin{array}{l}\text { Upper } \\
\text { Bound }\end{array}$ & Value & df1 & $\mathrm{df} 2$ & Sig & $\begin{array}{l}\text { Lower } \\
\text { Bound }\end{array}$ \\
\hline \multirow[t]{6}{*}{ CUSTOMIZED } & 10 & $\begin{array}{l}\text { Single } \\
\text { Measures }\end{array}$ & $.538(b)$ & .138 & .788 & 3.333 & 19 & 19 & .006 \\
\hline & & $\begin{array}{l}\text { Average } \\
\text { Measures }\end{array}$ & $.700(\mathrm{c})$ & .242 & .881 & 3.333 & 19 & 19 & .006 \\
\hline & 20 & $\begin{array}{l}\text { Single } \\
\text { Measures }\end{array}$ & $.409(b)$ & -.030 & .715 & 2.381 & 19 & 19 & .033 \\
\hline & & $\begin{array}{l}\text { Average } \\
\text { Measures }\end{array}$ & $.580(\mathrm{c})$ & -.061 & .834 & 2.381 & 19 & 19 & .033 \\
\hline & 40 & $\begin{array}{l}\text { Single } \\
\text { Measures }\end{array}$ & $.379(b)$ & -.064 & .697 & 2.220 & 19 & 19 & .045 \\
\hline & & $\begin{array}{l}\text { Average } \\
\text { Measures }\end{array}$ & $.550(c)$ & -.138 & 822 & 2.220 & 19 & 19 & .045 \\
\hline \multirow[t]{6}{*}{ AVERAGE } & 10 & $\begin{array}{l}\text { Single } \\
\text { Measures }\end{array}$ & $.939(b)$ & .852 & .975 & 31.667 & 19 & 19 & .000 \\
\hline & & $\begin{array}{l}\text { Average } \\
\text { Measures }\end{array}$ & $.968(\mathrm{c})$ & .920 & .988 & 31.667 & 19 & 19 & .000 \\
\hline & 20 & $\begin{array}{l}\text { Single } \\
\text { Measures }\end{array}$ & $.415(\mathrm{~b})$ & -.021 & .719 & 2.421 & 19 & 19 & .031 \\
\hline & & $\begin{array}{l}\text { Average } \\
\text { Measures }\end{array}$ & $.587(\mathrm{c})$ & -.044 & .837 & 2.421 & 19 & 19 & .031 \\
\hline & 40 & $\begin{array}{l}\text { Single } \\
\text { Measures }\end{array}$ & $.389(b)$ & -.053 & .704 & 2.274 & 19 & 19 & .041 \\
\hline & & $\begin{array}{l}\text { Average } \\
\text { Measures }\end{array}$ & $.560(c)$ & -.111 & .826 & 2.274 & 19 & 19 & .041 \\
\hline
\end{tabular}

Two-way mixed effects model where people effects are random and measures effects are fixed.

a Type $\mathrm{C}$ intraclass correlation coefficients using a consistency definition-the between-measure variance is excluded from the denominator variance.

$b$ The estimator is the same, whether the interaction effect is present or not.

c This estimate is computed assuming the interaction effect is absent, because it is not estimable otherwise.

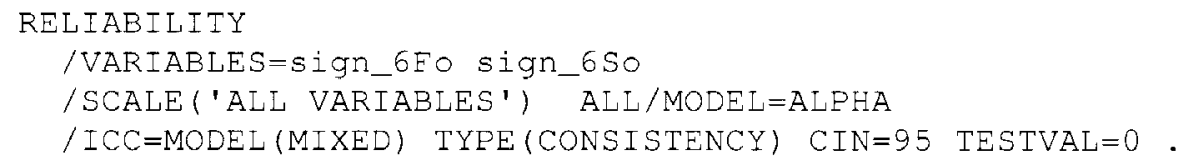

\title{
Reliability--TWO RATERS--SIGN 6 ORIGINAL
}

\author{
Notes
}

[Dataset 1]

\section{Scale: ALL VARIABLES}

Case Processing Summary 


\begin{tabular}{|c|c|c|c|c|c|}
\hline arch form & tro width & & & $N$ & $\%$ \\
\hline \multirow[t]{9}{*}{ CUSTOMIZED } & 10 & Cases & Valid & 20 & 100.0 \\
\hline & & & $\begin{array}{l}\text { Excluded( } \\
\text { a) }\end{array}$ & 0 & .0 \\
\hline & & & Total & 20 & 100.0 \\
\hline & 20 & Cases & Valid & 20 & 100.0 \\
\hline & & & $\begin{array}{l}\text { Excluded( } \\
\text { a) }\end{array}$ & 0 & .0 \\
\hline & & & Total & 20 & 100.0 \\
\hline & 40 & Cases & Valid & 20 & 100.0 \\
\hline & & & $\begin{array}{l}\text { Excluded( } \\
\text { a) }\end{array}$ & 0 & .0 \\
\hline & & & Total & 20 & 100.0 \\
\hline \multirow{9}{*}{ AVERAGE } & 10 & Cases & Valid & 20 & 100.0 \\
\hline & & & $\begin{array}{l}\text { Excluded( } \\
\text { a) }\end{array}$ & 0 & .0 \\
\hline & & & Total & 20 & 100.0 \\
\hline & 20 & Cases & Valid & 20 & 100.0 \\
\hline & & & $\begin{array}{l}\text { Excluded( } \\
\text { a) }\end{array}$ & 0 & .0 \\
\hline & & & Total & 20 & 100.0 \\
\hline & 40 & Cases & Valid & 20 & 100.0 \\
\hline & & & $\begin{array}{l}\text { Excluded( } \\
\text { a) }\end{array}$ & 0 & .0 \\
\hline & & & Total & 20 & 100.0 \\
\hline
\end{tabular}

a Listwise deletion based on all variables in the procedure.

\section{Reliability Statistics}

\begin{tabular}{|ll|r|r|}
\hline arch form & tro width & $\begin{array}{c}\text { Cronbach's } \\
\text { Alpha(a) }\end{array}$ & N of Items \\
\hline CUSTOMIZED & 10 & -.667 & 2 \\
& 20 & -.600 & 2 \\
& 40 & .581 & 2 \\
AVERAGE & 10 & .913 & 2 \\
& 20 & .510 & 2 \\
& 40 & .485 & 2 \\
\hline
\end{tabular}

a The value is negative due to a negative average covariance among items. This violates reliability model assumptions. You may want to check item codings.

Intraclass Correlation Coefficient

\begin{tabular}{|l|c|c|c|}
\hline arch_form tro_width & $\begin{array}{c}\text { Intraclass } \\
\text { Correlation(a) }\end{array}$ & $\begin{array}{c}95 \% \text { Confidence } \\
\text { Interval }\end{array}$ & F Test with True Value 0 \\
\hline
\end{tabular}




\begin{tabular}{|c|c|c|c|c|c|c|c|c|c|}
\hline & & & & $\begin{array}{l}\text { Upper } \\
\text { Bound }\end{array}$ & Value & $\mathrm{df} 1$ & $\mathrm{df} 2$ & Sig & $\begin{array}{l}\text { Lower } \\
\text { Bound }\end{array}$ \\
\hline \multirow[t]{6}{*}{ CUSTOMIZED } & \multirow[t]{2}{*}{10} & $\begin{array}{l}\text { Single } \\
\text { Measures }\end{array}$ & $-.250(b)$ & -.616 & .205 & .600 & 19 & 19 & .863 \\
\hline & & $\begin{array}{l}\text { Average } \\
\text { Measures }\end{array}$ & $-.667(c)$ & -3.211 & .340 & .600 & 19 & 19 & .863 \\
\hline & 20 & $\begin{array}{l}\text { Single } \\
\text { Measures }\end{array}$ & $-.231(\mathrm{~b})$ & -.603 & .225 & .625 & 19 & 19 & .843 \\
\hline & & $\begin{array}{l}\text { Average } \\
\text { Measures }\end{array}$ & $-.600(\mathrm{c})$ & -3.042 & .367 & .625 & 19 & 19 & .843 \\
\hline & 40 & $\begin{array}{l}\text { Single } \\
\text { Measures }\end{array}$ & $.410(\mathrm{~b})$ & -.028 & .716 & 2.389 & 19 & 19 & .033 \\
\hline & & $\begin{array}{l}\text { Average } \\
\text { Measures }\end{array}$ & $.581(\mathrm{c})$ & -.058 & .834 & 2.389 & 19 & 19 & .033 \\
\hline AVERAGE & 10 & $\begin{array}{l}\text { Single } \\
\text { Measures }\end{array}$ & $.839(b)$ & .638 & .933 & 11.435 & 19 & 19 & .000 \\
\hline & & $\begin{array}{l}\text { Average } \\
\text { Measures }\end{array}$ & $.913(\mathrm{c})$ & .779 & .965 & 11.435 & 19 & 19 & .000 \\
\hline & 20 & $\begin{array}{l}\text { Single } \\
\text { Measures }\end{array}$ & $.342(\mathrm{~b})$ & -.106 & .675 & 2.042 & 19 & 19 & .064 \\
\hline & & $\begin{array}{l}\text { Average } \\
\text { Measures }\end{array}$ & $.510(\mathrm{c})$ & -.237 & .806 & 2.042 & 19 & 19 & .064 \\
\hline & 40 & $\begin{array}{l}\text { Single } \\
\text { Measures }\end{array}$ & $.321(b)$ & -.130 & .662 & 1.943 & 19 & 19 & .078 \\
\hline & & $\begin{array}{l}\text { Average } \\
\text { Measures }\end{array}$ & $.485(c)$ & -.300 & .796 & 1.943 & 19 & 19 & .078 \\
\hline
\end{tabular}

Two-way mixed effects model where people effects are random and measures effects are fixed.

a Type $\mathrm{C}$ intraclass correlation coefficients using a consistency definition-the between-measure variance is excluded from the denominator variance.

$b$ The estimator is the same, whether the interaction effect is present or not.

c This estimate is computed assuming the interaction effect is absent, because it is not estimable otherwise.

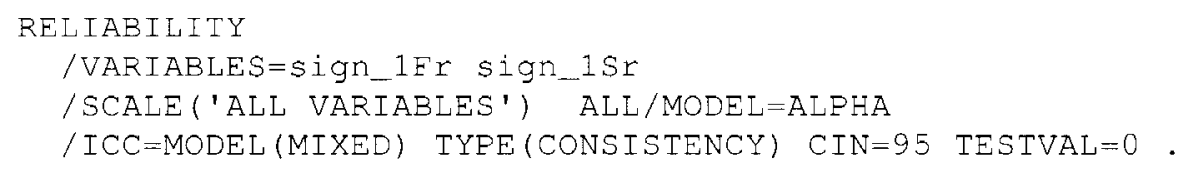

\title{
Reliability--TWO RATERS--SIGN 1 REPEAT
}

\author{
Notes
}

[Dataset 1]

\section{Scale: ALL VARIABLES}

\section{Case Processing Summary}

\begin{tabular}{|l|l|l|}
\hline arch form tro width & $\mathrm{N}$ & $\%$ \\
\hline
\end{tabular}




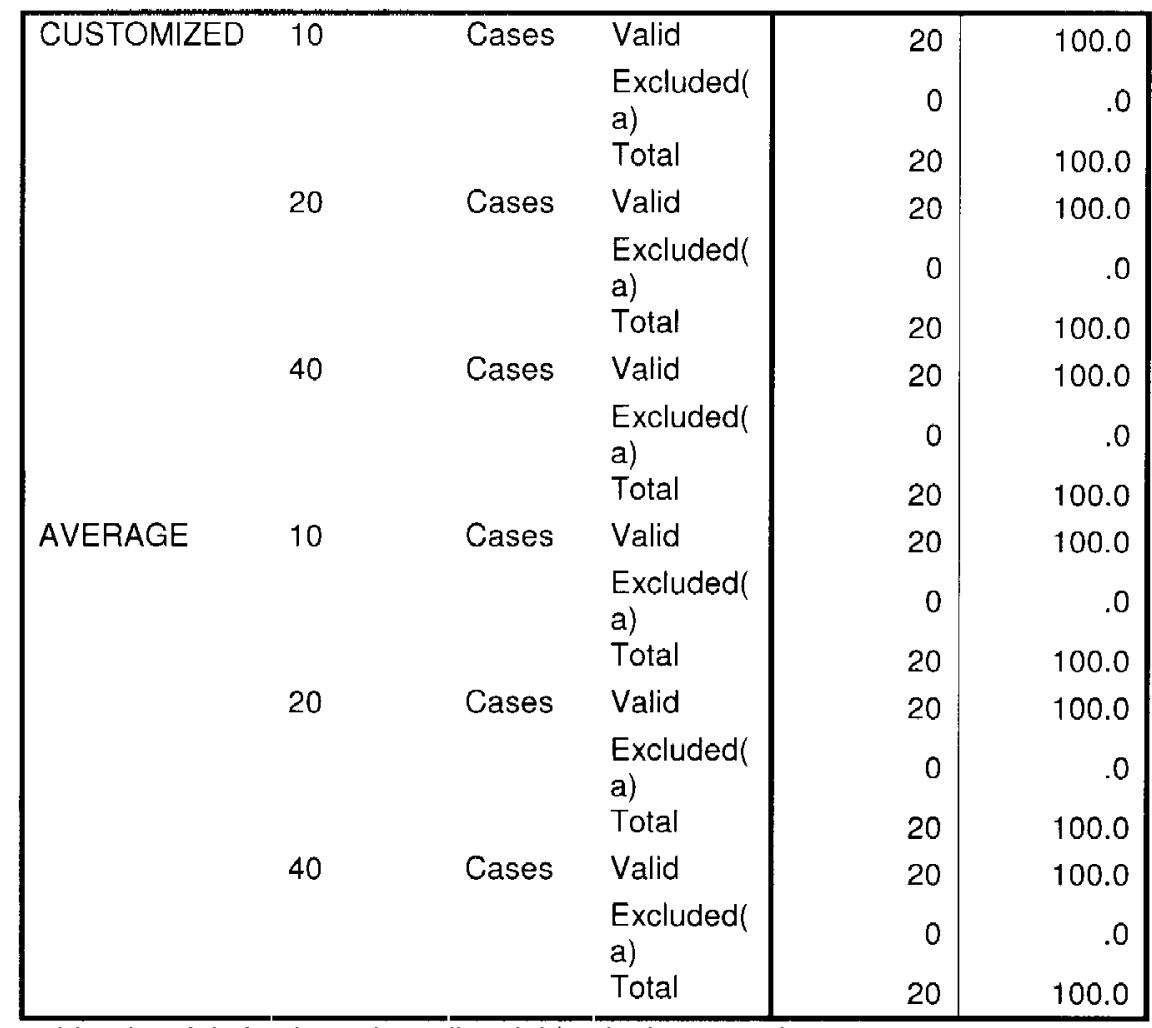

a Listwise deletion based on all variables in the procedure.

\section{Reliability Statistics}

\begin{tabular}{|ll|r|r|}
\hline arch form & tro_width & $\begin{array}{c}\text { Cronbach's } \\
\text { Alpha(a) }\end{array}$ & N of Items \\
\hline CUSTOMIZED & 10 & .226 & 2 \\
& 20 & -.404 & 2 \\
AVERAGE & 40 & -.015 & 2 \\
& 20 & .882 & 2 \\
& 40 & .484 & 2 \\
& 40 & .412 & 2 \\
\hline
\end{tabular}

a The value is negative due to a negative average covariance among items. This violates reliability model assumptions. You may want to check item codings.

Intraclass Correlation Coefficient

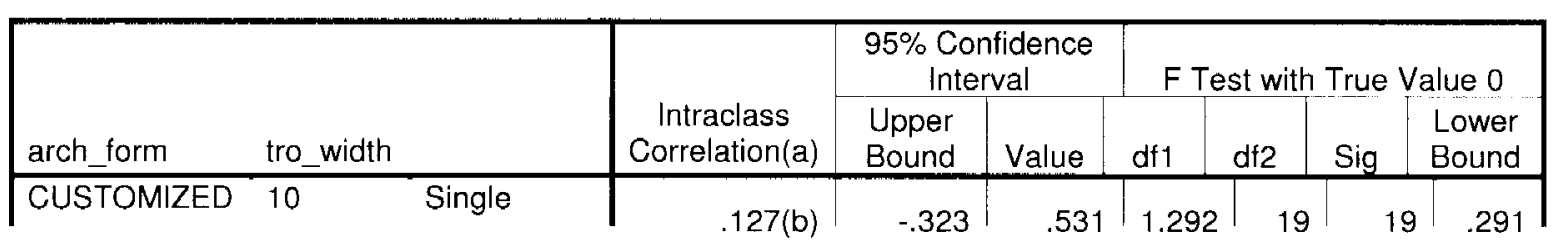




\begin{tabular}{|c|c|c|c|c|c|c|c|c|c|}
\hline & & Measures & & & & & & & \\
\hline & & $\begin{array}{l}\text { Average } \\
\text { Measures }\end{array}$ & $.226(c)$ & -.956 & .694 & 1.292 & 19 & 19 & .291 \\
\hline & 20 & $\begin{array}{l}\text { Single } \\
\text { Measures }\end{array}$ & $-.168(b)$ & -.560 & .286 & .712 & 19 & 19 & .767 \\
\hline & & $\begin{array}{l}\text { Average } \\
\text { Measures }\end{array}$ & $\cdot .404(c)$ & -2.547 & .444 & .712 & 19 & 19 & .767 \\
\hline & 40 & $\begin{array}{l}\text { Single } \\
\text { Measures }\end{array}$ & $-.008(b)$ & -.439 & .427 & .985 & 19 & 19 & .513 \\
\hline & & $\begin{array}{l}\text { Average } \\
\text { Measures }\end{array}$ & $-.015(c)$ & -1.565 & .598 & .985 & 19 & 19 & .513 \\
\hline AVERAGE & 10 & $\begin{array}{l}\text { Single } \\
\text { Measures }\end{array}$ & $.789(b)$ & .541 & .911 & 8.473 & 19 & 19 & .000 \\
\hline & & $\begin{array}{l}\text { Average } \\
\text { Measures }\end{array}$ & $.882(c)$ & .702 & .953 & 8.473 & 19 & 19 & .000 \\
\hline & 20 & $\begin{array}{l}\text { Single } \\
\text { Measures }\end{array}$ & $.319(b)$ & -.132 & .661 & 1.938 & 19 & 19 & .079 \\
\hline & & $\begin{array}{l}\text { Average } \\
\text { Measures }\end{array}$ & $.484(c)$ & -.304 & .796 & 1.938 & 19 & 19 & .079 \\
\hline & 40 & $\begin{array}{l}\text { Single } \\
\text { Measures }\end{array}$ & $.259(b)$ & -.196 & .622 & 1.700 & 19 & 19 & .128 \\
\hline & & $\begin{array}{l}\text { Average } \\
\text { Measures }\end{array}$ & $.412(c)$ & -.486 & .767 & 1.700 & 19 & 19 & .128 \\
\hline
\end{tabular}

Two-way mixed effects model where people effects are random and measures effects are fixed.

a Type $C$ intraclass correlation coefficients using a consistency definition-the between-measure variance is excluded from the denominator variance.

b The estimator is the same, whether the interaction effect is present or not.

c This estimate is computed assuming the interaction effect is absent, because it is not estimable otherwise.

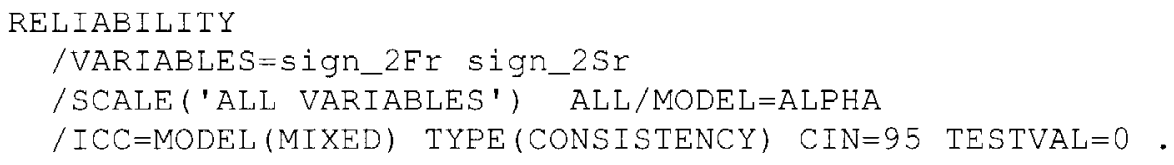

\section{Reliability--TWO RATERS--SIGN 2 REPEAT}

Notes

[Dataset1]

\section{Scale: ALL VARIABLES}

Case Processing Summary

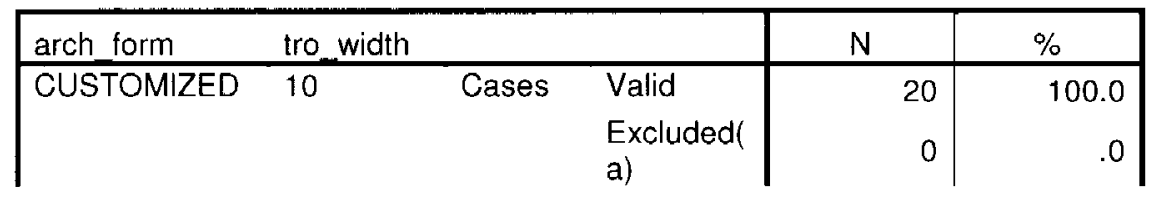




\begin{tabular}{|c|c|c|c|c|c|}
\hline & 20 & Cases & $\begin{array}{l}\text { Total } \\
\text { Valid }\end{array}$ & 20 & 100.0 \\
\hline & & Vases & Excluded & 20 & 100.0 \\
\hline & & & $\begin{array}{l}\text { a) } \\
\text { Total }\end{array}$ & 0 & .0 \\
\hline & 40 & Cases & Valid & 20 & 100.0 \\
\hline & & & $\begin{array}{l}\text { Excluded( } \\
\text { a) }\end{array}$ & 0 & .0 \\
\hline & & & Total & 20 & 100.0 \\
\hline AVERAGE & 10 & Cases & Valid & 20 & 100.0 \\
\hline & & & $\begin{array}{l}\text { Excluded( } \\
\text { a) }\end{array}$ & 0 & .0 \\
\hline & & & Total & 20 & 100.0 \\
\hline & 20 & Cases & Valid & 20 & 100.0 \\
\hline & & & $\begin{array}{l}\text { Excluded( } \\
\text { a) }\end{array}$ & 0 & .0 \\
\hline & & & Total & 20 & 100.0 \\
\hline & 40 & Cases & Valid & 20 & 100.0 \\
\hline & & & $\begin{array}{l}\text { Excluded( } \\
\text { a) }\end{array}$ & 0 & 0 \\
\hline & & & Total & 20 & 100.0 \\
\hline
\end{tabular}

a Listwise deletion based on all variables in the procedure.

\section{Reliability Statistics}

\begin{tabular}{|ll|r|r|}
\hline arch form & tro width & $\begin{array}{c}\text { Cronbach's } \\
\text { Alpha(a) }\end{array}$ & N of ltems \\
\hline CUSTOMIZED & 10 & -.029 & 2 \\
& 20 & .742 & 2 \\
& 40 & -.234 & 2 \\
AVERAGE & 10 & .969 & 2 \\
& 20 & .697 & 2 \\
& 40 & .473 & 2 \\
\hline
\end{tabular}

a The value is negative due to a negative average covariance among items. This violates reliability model assumptions. You may want to check item codings.

Intraclass Correlation Coefficient

\begin{tabular}{|c|c|c|c|c|c|c|c|c|c|}
\hline \multirow[b]{2}{*}{ arch_form } & \multirow[b]{2}{*}{ tro_width } & & \multirow[b]{2}{*}{$\begin{array}{c}\text { Intraclass } \\
\text { Correlation(a) }\end{array}$} & \multicolumn{2}{|c|}{$\begin{array}{l}95 \% \text { Confidence } \\
\text { Interval }\end{array}$} & \multicolumn{4}{|c|}{ F Test with True Value 0} \\
\hline & & & & $\begin{array}{l}\text { Upper } \\
\text { Bound }\end{array}$ & Value & df 1 & $\mathrm{df} 2$ & Sig & $\begin{array}{l}\text { Lower } \\
\text { Bound }\end{array}$ \\
\hline \multirow[t]{2}{*}{ CUSTOMIZED } & 10 & $\begin{array}{l}\text { Single } \\
\text { Measures }\end{array}$ & $-.014(\mathrm{~b})$ & -.444 & .421 & .97 & 19 & 19 & .524 \\
\hline & & $\begin{array}{l}\text { Average } \\
\text { Measures }\end{array}$ & $-.029(\mathrm{c})$ & -1.599 & .593 & .97 & 19 & 19 & .524 \\
\hline
\end{tabular}




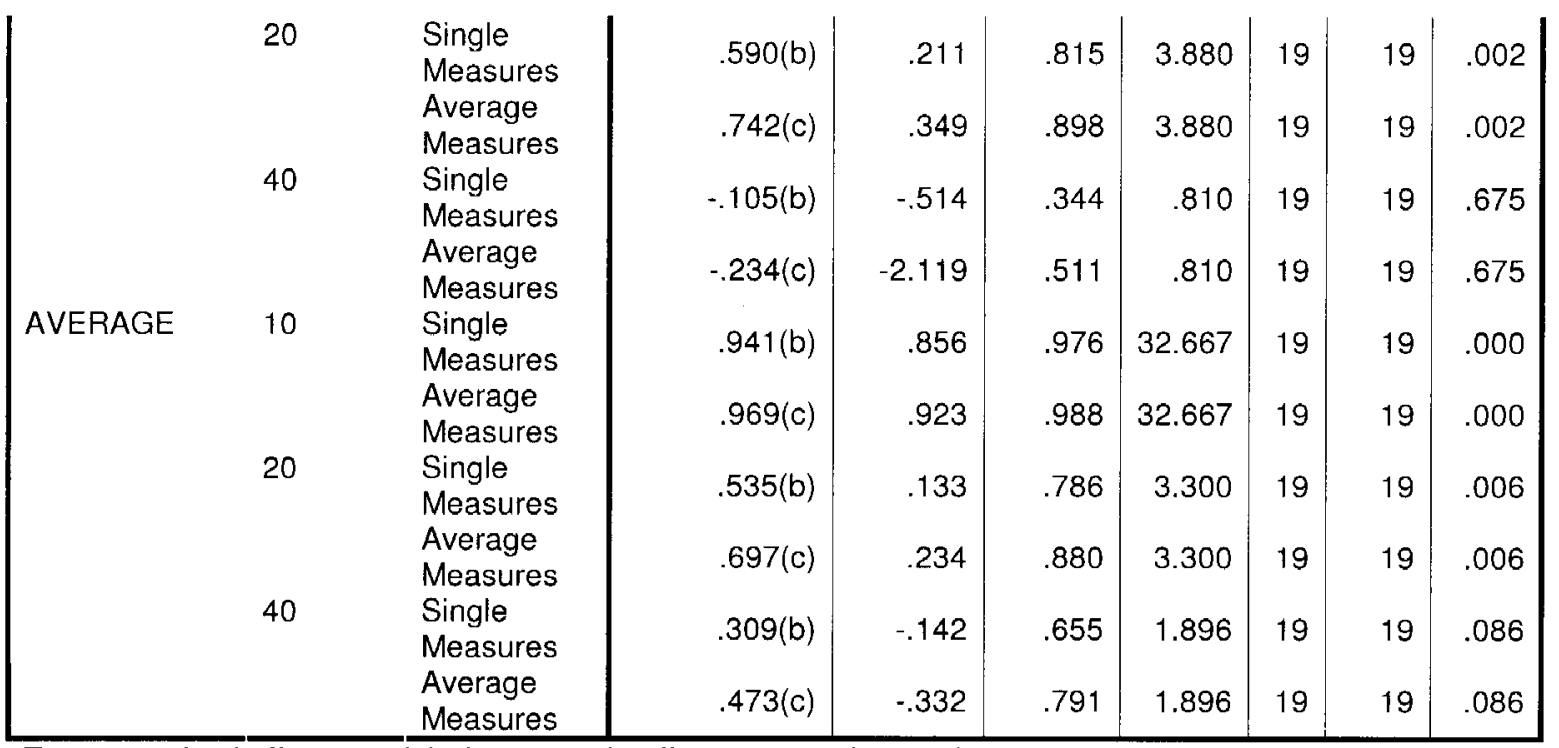

Two-way mixed effects model where people effects are random and measures effects are fixed.

a Type $\mathrm{C}$ intraclass correlation coefficients using a consistency definition-the between-measure variance is excluded from the denominator variance.

b The estimator is the same, whether the interaction effect is present or not.

c This estimate is computed assuming the interaction effect is absent, because it is not estimable otherwise.

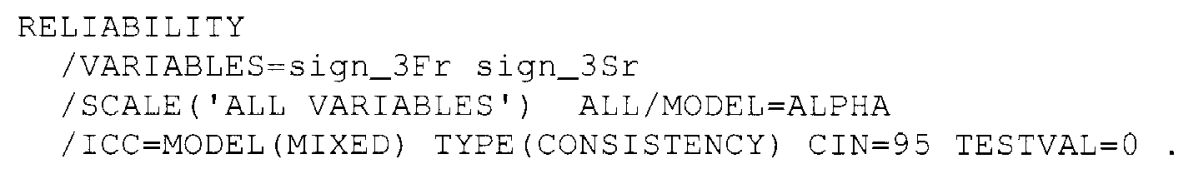

\title{
Reliability--TWO RATERS--SIGN 3 REPEAT
}

\author{
Notes
}

[Dataset 1]

Scale: ALL VARIABLES

Case Processing Summary

\begin{tabular}{|llll|r|r|}
\hline arch form & tro width & & $N$ & \multicolumn{1}{c|}{$\%$} \\
\hline CUSTOMIZED & 10 & Cases & Valid & 20 & 100.0 \\
& & & Excluded & 0 & .0 \\
& & a) & 20 & 100.0 \\
& & Total & 20 & 100.0 \\
& 20 & Cases & Valid & &
\end{tabular}




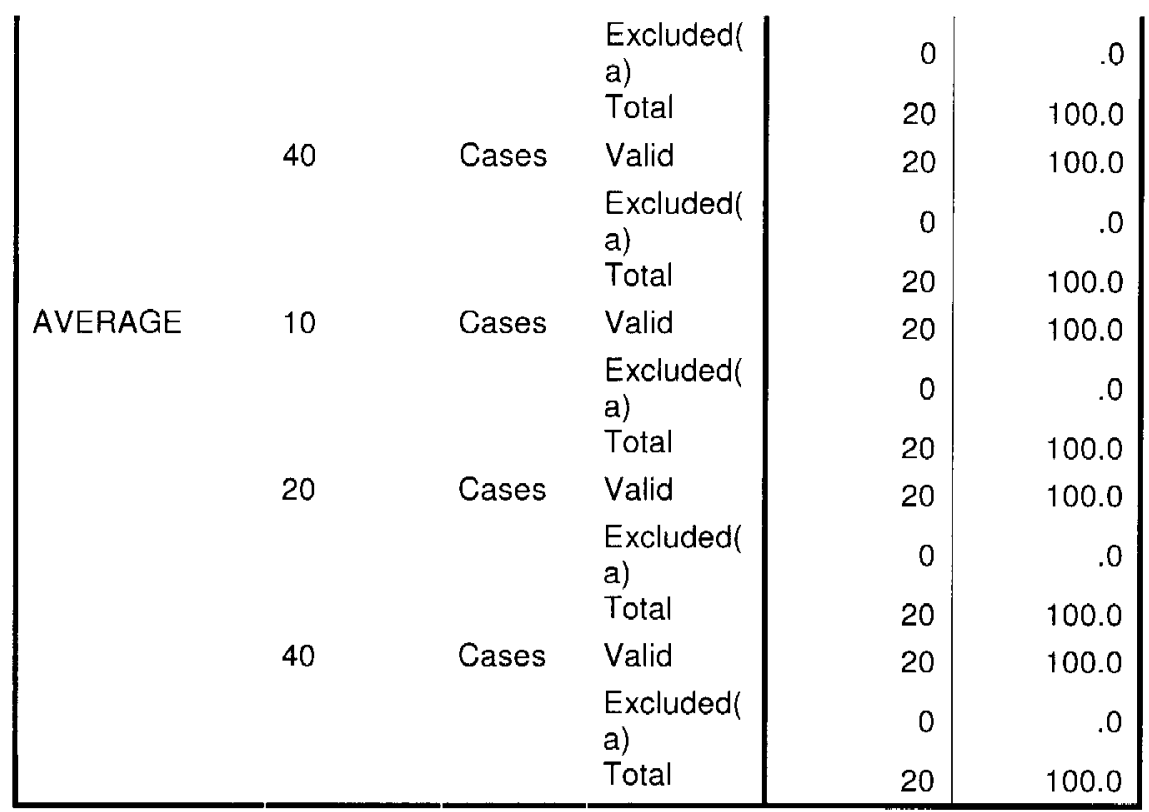

a Listwise deletion based on all variables in the procedure.

\section{Reliability Statistics}

\begin{tabular}{|ll|r|r|}
\hline arch_form & tro width & $\begin{array}{c}\text { Cronbach's } \\
\text { Alpha }\end{array}$ & N of Items \\
\hline CUSTOMIZED & 10 & .702 & 2 \\
& 20 & 1.000 & 2 \\
& 40 & .031 & 2 \\
AVERAGE & 10 & .958 & 2 \\
& 20 & .821 & 2 \\
& 40 & .598 & 2 \\
\hline
\end{tabular}

Intraclass Correlation Coefficient

\begin{tabular}{|c|c|c|c|c|c|c|c|c|c|}
\hline \multirow[b]{2}{*}{ arch_form } & \multirow[b]{2}{*}{ tro_width } & & \multirow[b]{2}{*}{$\begin{array}{c}\text { Intraclass } \\
\text { Correlation(a) }\end{array}$} & \multicolumn{2}{|c|}{$\begin{array}{l}\text { 95\% Confidence } \\
\text { Interval }\end{array}$} & \multicolumn{4}{|c|}{ F Test with True Value 0} \\
\hline & & & & $\begin{array}{l}\text { Upper } \\
\text { Bound }\end{array}$ & Value & df1 & $\mathrm{df} 2$ & Sig & $\begin{array}{l}\text { Lower } \\
\text { Bound }\end{array}$ \\
\hline \multirow[t]{5}{*}{ CUSTOMIZED } & 10 & $\begin{array}{l}\text { Single } \\
\text { Measures }\end{array}$ & $.541(b)$ & .141 & .789 & 3.353 & \begin{tabular}{l|l}
3 & 19
\end{tabular} & 19 & .006 \\
\hline & & $\begin{array}{l}\text { Average } \\
\text { Measures }\end{array}$ & $.702(\mathrm{c})$ & .246 & .882 & 3.353 & $\begin{array}{l}319 \\
3\end{array}$ & 19 & .006 \\
\hline & 20 & $\begin{array}{l}\text { Single } \\
\text { Measures }\end{array}$ & $1.000(b)$ & 1.000 & 1.000 & & 19 & & \\
\hline & & $\begin{array}{l}\text { Average } \\
\text { Measures }\end{array}$ & & 1.000 & 1.000 & & 19 & & \\
\hline & 40 & Single & $.016(b)$ & -.420 & .446 & 1.032 & 19 & 19 & .473 \\
\hline
\end{tabular}




\begin{tabular}{|c|c|c|c|c|c|c|c|c|c|}
\hline & & Measures & & & & & & & \\
\hline & & $\begin{array}{l}\text { Average } \\
\text { Measures }\end{array}$ & $.031(\mathrm{c})$ & -1.448 & .616 & 1.032 & 19 & 19 & .473 \\
\hline AVERAGE & 10 & $\begin{array}{l}\text { Single } \\
\text { Measures }\end{array}$ & $.920(\mathrm{~b})$ & .809 & .967 & 23.915 & 19 & 19 & .000 \\
\hline & & $\begin{array}{l}\text { Average } \\
\text { Measures }\end{array}$ & $.958(c)$ & .894 & .983 & 23.915 & 19 & 19 & .000 \\
\hline & 20 & $\begin{array}{l}\text { Single } \\
\text { Measures }\end{array}$ & $.696(b)$ & .377 & .868 & 5.588 & 19 & 19 & .000 \\
\hline & & $\begin{array}{l}\text { Average } \\
\text { Measures }\end{array}$ & $.821(\mathrm{c})$ & .548 & .929 & 5.588 & 19 & 19 & .000 \\
\hline & 40 & $\begin{array}{l}\text { Single } \\
\text { Measures }\end{array}$ & $.427(b)$ & .007 & .726 & 2.489 & 19 & 19 & .027 \\
\hline & & $\begin{array}{l}\text { Average } \\
\text { Measures }\end{array}$ & $.598(\mathrm{c})$ & -.015 & .841 & 2.489 & 19 & 19 & .027 \\
\hline
\end{tabular}

Two-way mixed effects model where people effects are random and measures effects are fixed.

a Type $C$ intraclass correlation coefficients using a consistency definition-the between-measure variance is excluded from the denominator variance.

b The estimator is the same, whether the interaction effect is present or not.

c This estimate is computed assuming the interaction effect is absent, because it is not estimable otherwise.

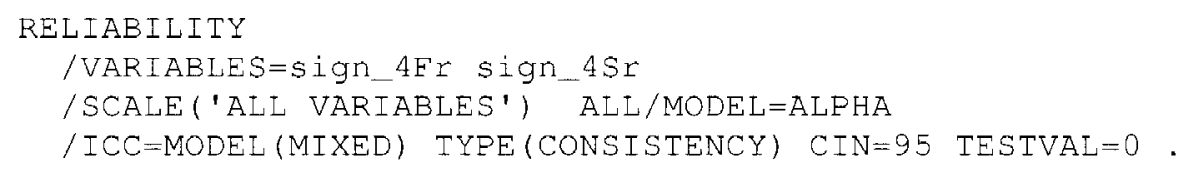

\section{Reliability--TWO RATERS--SIGN 4 REPEAT}

Notes

[Dataset1]

\section{Scale: ALL VARIABLES}

Case Processing Summary

\begin{tabular}{|llll|r|r|}
\hline arch form & tro width & & $\mathrm{N}$ & \multicolumn{1}{c|}{$\%$} \\
\hline CUSTOMIZED & 10 & Cases & Valid & 20 & 100.0 \\
& & & Excluded( & 0 & .0 \\
& & a) & 20 & 100.0 \\
& & Total & 20 & 100.0 \\
& \multirow{2}{*}{ Cases } & Valid & & 0 & .0 \\
& & Excluded( & 20 & 100.0 \\
& & a) & 20 & 100.0
\end{tabular}




\begin{tabular}{|c|c|c|c|c|c|}
\hline & & & $\begin{array}{l}\text { Excluded( } \\
\text { a) } \\
\text { Total }\end{array}$ & $\begin{array}{r}0 \\
20\end{array}$ & $\begin{array}{r}.0 \\
100.0\end{array}$ \\
\hline \multirow[t]{9}{*}{ AVERAGE } & 10 & Cases & Valid & 20 & 100.0 \\
\hline & & & $\begin{array}{l}\text { Excluded( } \\
\text { a) }\end{array}$ & 0 & .0 \\
\hline & & & Total & 20 & 100.0 \\
\hline & 20 & Cases & Valid & 20 & 100.0 \\
\hline & & & $\begin{array}{l}\text { Excluded( } \\
\text { a) }\end{array}$ & 0 & .0 \\
\hline & & & Total & 20 & 100.0 \\
\hline & 40 & Cases & Valid & 20 & 100.0 \\
\hline & & & $\begin{array}{l}\text { Excluded( } \\
\text { a) }\end{array}$ & 0 & .0 \\
\hline & & & Total & 20 & 100.0 \\
\hline
\end{tabular}

a Listwise deletion based on all variables in the procedure.

\section{Reliability Statistics}

\begin{tabular}{|ll|r|r|}
\hline arch_form & tro_width & $\begin{array}{c}\text { Cronbach's } \\
\text { Alpha(a) }\end{array}$ & N of Items \\
\hline CUSTOMIZED & 10 & -.292 & 2 \\
& 20 & .000 & 2 \\
& 40 & .169 & 2 \\
AVERAGE & 10 & .952 & 2 \\
& 20 & .805 & 2 \\
& 40 & .658 & 2 \\
\hline
\end{tabular}

a The value is negative due to a negative average covariance among items. This violates reliability model assumptions. You may want to check item codings.

Intraclass Correlation Coefficient

\begin{tabular}{|c|c|c|c|c|c|c|c|c|c|}
\hline \multirow[b]{2}{*}{ arch_form } & \multirow[b]{2}{*}{ tro_width } & & \multirow[b]{2}{*}{$\begin{array}{l}\text { Intraclass } \\
\text { Correlation(a) }\end{array}$} & \multicolumn{2}{|c|}{$\begin{array}{l}95 \% \text { Confidence } \\
\text { Interval }\end{array}$} & \multicolumn{4}{|c|}{ F Test with True Value 0} \\
\hline & & & & $\begin{array}{l}\text { Upper } \\
\text { Bound }\end{array}$ & Value & df1 1 & $\mathrm{df} 2$ & Sig & $\begin{array}{l}\text { Lower } \\
\text { Bound }\end{array}$ \\
\hline \multirow[t]{6}{*}{ CUSTOMIZED } & 10 & $\begin{array}{l}\text { Single } \\
\text { Measures }\end{array}$ & $-.127(b)$ & -.531 & .323 & .774 & 19 & 19 & .709 \\
\hline & & $\begin{array}{l}\text { Average } \\
\text { Measures }\end{array}$ & $.292(c)$ & -2.263 & .489 & .774 & 19 & 19 & .709 \\
\hline & 20 & $\begin{array}{l}\text { Single } \\
\text { Measures }\end{array}$ & $.000(\mathrm{~b})$ & -.433 & .433 & 1.000 & 19 & 19 & .500 \\
\hline & & $\begin{array}{l}\text { Average } \\
\text { Measures }\end{array}$ & $.000(\mathrm{c})$ & -1.526 & .604 & 1.000 & 19 & 19 & .500 \\
\hline & 40 & $\begin{array}{l}\text { Single } \\
\text { Measures }\end{array}$ & $.092(b)$ & -.355 & .505 & 1.204 & 19 & 19 & .345 \\
\hline & & $\begin{array}{l}\text { Average } \\
\text { Measures }\end{array}$ & $.169(\mathrm{c})$ & -1.099 & .671 & 1.204 & 19 & 19 & .345 \\
\hline
\end{tabular}




\begin{tabular}{|c|c|c|c|c|c|c|c|c|c|}
\hline AVERAGE & 20 & $\begin{array}{l}\text { Single } \\
\text { Measures } \\
\text { Average } \\
\text { Measures } \\
\text { Single } \\
\text { Measures } \\
\text { Average } \\
\text { Measures } \\
\text { Single } \\
\text { Measures } \\
\text { Average } \\
\text { Measures }\end{array}$ & $\begin{array}{l}.909(\mathrm{~b}) \\
.952(\mathrm{c}) \\
.674(\mathrm{~b}) \\
.805(\mathrm{c}) \\
.490(\mathrm{~b}) \\
.658(\mathrm{c})\end{array}$ & $\begin{array}{l}.785 \\
.880 \\
.340 \\
.507 \\
.073 \\
.136\end{array}$ & $\begin{array}{l}.963 \\
.981 \\
.857 \\
.923 \\
.762 \\
.865\end{array}$ & $\begin{array}{r}21.000 \\
21.000 \\
5.128 \\
5.128 \\
2.924 \\
2.924\end{array}$ & 19 & $\begin{array}{l}19 \\
19\end{array}$ & $\begin{array}{l}.000 \\
.000 \\
.000 \\
.000 \\
.012 \\
.012\end{array}$ \\
\hline
\end{tabular}

Two-way mixed effects model where people effects are random and measures effects are fixed.

a Type $C$ intraclass correlation coefficients using a consistency definition-the between-measure variance is excluded from the denominator variance.

b The estimator is the same, whether the interaction effect is present or not.

c This estimate is computed assuming the interaction effect is absent, because it is not estimable otherwise.

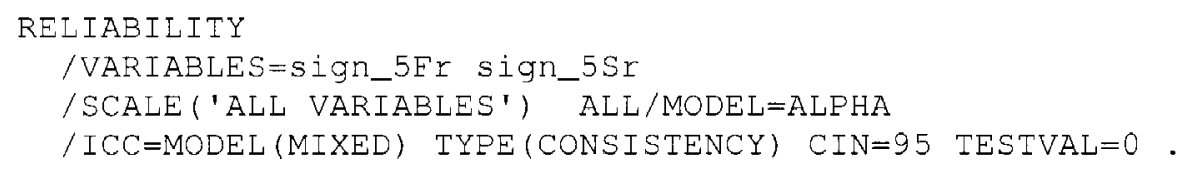

\section{Reliability--TWO RATERS--SIGN 5 REPEAT}

\section{Notes}

[Dataset 1]

\section{Warnings}

For split file arch_form=CUSTOMIZED,tro_width=20, scale has zero variance items.

\section{Scale: ALL VARIABLES}

Case Processing Summary

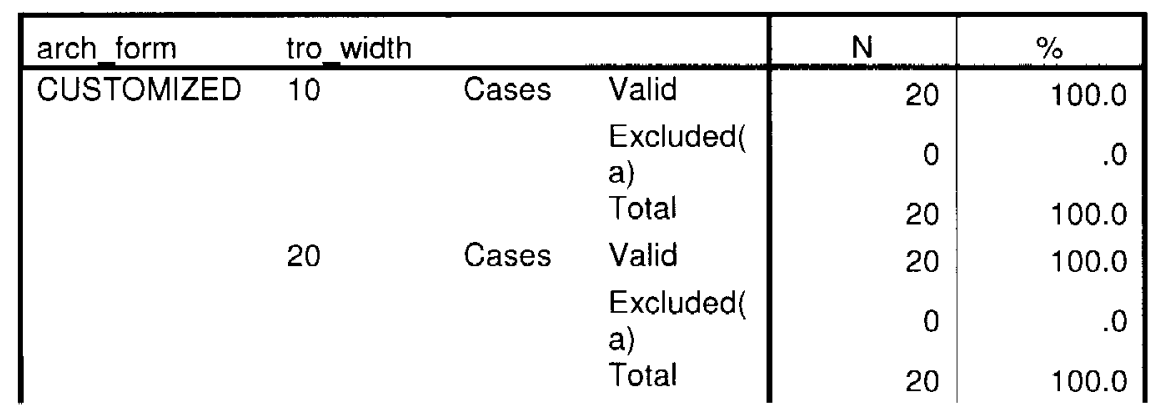




\begin{tabular}{|c|c|c|c|c|c|}
\hline & 40 & Cases & Valid & 20 & 100.0 \\
\hline & & & & 0 & .0 \\
\hline & & & Total & 20 & 100.0 \\
\hline AVERAGE & 10 & Cases & Valid & 20 & 100.0 \\
\hline & & & $\begin{array}{l}\text { Excluded( } \\
\text { a) }\end{array}$ & 0 & .0 \\
\hline & & & Total & 20 & 100.0 \\
\hline & 20 & Cases & Valid & 20 & 100.0 \\
\hline & & & $\begin{array}{l}\text { Excluded( } \\
\text { a) }\end{array}$ & 0 & .0 \\
\hline & & & Total & 20 & 100.0 \\
\hline & 40 & Cases & Valid & 20 & 100.0 \\
\hline & & & $\begin{array}{l}\text { Excluded( } \\
\text { a) }\end{array}$ & 0 & .0 \\
\hline & & & Total & 20 & 100.0 \\
\hline
\end{tabular}

a Listwise deletion based on all variables in the procedure.

\section{Reliability Statistics}

\begin{tabular}{|ll|r|r|}
\hline arch form & tro width & $\begin{array}{c}\text { Cronbach's } \\
\text { Alpha(a) }\end{array}$ & N of Items \\
\hline CUSTOMIZED & 10 & .345 & 2 \\
& 20 & $4.39 E-016$ & 2 \\
AVERAGE & 40 & -.894 & 2 \\
& 10 & .908 & 2 \\
& 20 & .801 & 2 \\
& 40 & .279 & 2 \\
\hline
\end{tabular}

a The value is negative due to a negative average covariance among items. This violates reliability model assumptions. You may want to check item codings.

Intraclass Correlation Coefficient

\begin{tabular}{|c|c|c|c|c|c|c|c|c|c|}
\hline \multirow[b]{2}{*}{ arch_form } & \multirow[b]{2}{*}{ tro_width } & & \multirow[b]{2}{*}{$\begin{array}{c}\text { Intraclass } \\
\text { Correlation(a) }\end{array}$} & \multicolumn{2}{|c|}{$\begin{array}{l}95 \% \text { Confidence } \\
\text { Interval }\end{array}$} & \multicolumn{4}{|c|}{ F Test with True Value 0} \\
\hline & & & & $\begin{array}{l}\text { Upper } \\
\text { Bound }\end{array}$ & Value & $\mathrm{df} 1$ & $\mathrm{df} 2$ & Sig & $\begin{array}{l}\text { Lower } \\
\text { Bound }\end{array}$ \\
\hline \multirow[t]{5}{*}{ CUSTOMIZED } & 10 & $\begin{array}{l}\text { Single } \\
\text { Measures }\end{array}$ & $.209(b)$ & -.246 & .588 & 1.527 & 19 & 19 & .182 \\
\hline & & $\begin{array}{l}\text { Average } \\
\text { Measures }\end{array}$ & $.345(c)$ & -.654 & .741 & 1.527 & 19 & 19 & .182 \\
\hline & 20 & $\begin{array}{l}\text { Single } \\
\text { Measures }\end{array}$ & $.000(b)$ & -.433 & .433 & 1.000 & 19 & 19 & .500 \\
\hline & & $\begin{array}{l}\text { Average } \\
\text { Measures }\end{array}$ & $.000(c)$ & -1.526 & .604 & 1.000 & 19 & 19 & .500 \\
\hline & 40 & $\begin{array}{l}\text { Single } \\
\text { Measures }\end{array}$ & $-.309(b)$ & -.654 & .143 & .528 & 19 & 19 & .913 \\
\hline
\end{tabular}




\begin{tabular}{|c|c|c|c|c|c|c|c|c|c|}
\hline \multirow{7}{*}{ AVERAGE } & \multirow[b]{2}{*}{10} & \multirow{2}{*}{$\begin{array}{l}\text { Average } \\
\text { Measures } \\
\text { Single } \\
\text { Measures }\end{array}$} & $-.894(\mathrm{c})$ & -3.785 & .250 & .528 & 19 & 19 & .913 \\
\hline & & & $.831(\mathrm{~b})$ & .621 & .929 & 10.813 & 19 & 19 & .000 \\
\hline & & $\begin{array}{l}\text { Average } \\
\text { Measures }\end{array}$ & $.908(\mathrm{c})$ & .766 & .963 & 10.813 & 19 & 19 & .000 \\
\hline & 20 & $\begin{array}{l}\text { Single } \\
\text { Measures }\end{array}$ & $.668(b)$ & .331 & .854 & 5.031 & 19 & 19 & .000 \\
\hline & & $\begin{array}{l}\text { Average } \\
\text { Measures }\end{array}$ & $.801(c)$ & .498 & .921 & 5.031 & 19 & 19 & .000 \\
\hline & 40 & $\begin{array}{l}\text { Single } \\
\text { Measures }\end{array}$ & $.162(b)$ & -.291 & .556 & 1.388 & 19 & 19 & $.24 \uparrow$ \\
\hline & & $\begin{array}{l}\text { Average } \\
\text { Measures }\end{array}$ & $.279(c)$ & 821 & .715 & 1.388 & 19 & 19 & .241 \\
\hline
\end{tabular}

Two-way mixed effects model where people effects are random and measures effects are fixed.

a Type $C$ intraclass correlation coefficients using a consistency definition-the between-measure variance is excluded from the denominator variance.

$b$ The estimator is the same, whether the interaction effect is present or not.

c This estimate is computed assuming the interaction effect is absent, because it is not estimable otherwise.

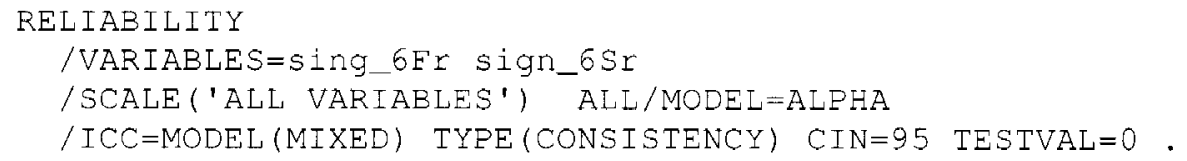

\section{Reliability--TWO RATERS--SIGN 6 REPEAT}

\section{Notes}

[Dataset1]

\section{Scale: ALL VARIABLES}

\section{Case Processing Summary}

\begin{tabular}{|c|c|c|c|c|c|}
\hline arch_form & tro & & & $N$ & $\%$ \\
\hline \multirow[t]{8}{*}{ CUSTOMIZED } & 10 & Cases & Valid & 20 & 100.0 \\
\hline & & & $\begin{array}{l}\text { Excluded( } \\
\text { a) }\end{array}$ & 0 & .0 \\
\hline & & & Total & 20 & 100.0 \\
\hline & 20 & Cases & Valid & 20 & 100.0 \\
\hline & & & $\begin{array}{l}\text { Excluded( } \\
\text { a) }\end{array}$ & 0 & .0 \\
\hline & & & Total & 20 & 100.0 \\
\hline & 40 & Cases & Valid & 20 & 100.0 \\
\hline & & & $\begin{array}{l}\text { Excluded( } \\
\text { a) }\end{array}$ & 0 & .0 \\
\hline
\end{tabular}




\begin{tabular}{|c|c|c|c|c|c|}
\hline \multirow{8}{*}{ AVERAGE } & \multirow{3}{*}{10} & \multirow[b]{2}{*}{ Cases } & \multirow{2}{*}{$\begin{array}{l}\text { Total } \\
\text { Valid }\end{array}$} & \multirow[t]{2}{*}{20} & 100.0 \\
\hline & & & & & 100.0 \\
\hline & & & $\begin{array}{l}\text { Excluded( } \\
\text { a) } \\
\text { Total }\end{array}$ & $\begin{array}{r}0 \\
20\end{array}$ & $\begin{array}{r}.0 \\
100.0\end{array}$ \\
\hline & 20 & Cases & Valid & 20 & 100.0 \\
\hline & & & $\begin{array}{l}\text { Excluded( } \\
\text { a) } \\
\text { Total }\end{array}$ & $\begin{array}{r}0 \\
20\end{array}$ & $\begin{array}{r}.0 \\
100.0\end{array}$ \\
\hline & 40 & Cases & Valid & 20 & 100.0 \\
\hline & & & $\begin{array}{l}\text { Excluded( } \\
\text { a) }\end{array}$ & 0 & \\
\hline & & & Total & 20 & 100.0 \\
\hline
\end{tabular}

a Listwise deletion based on all variables in the procedure.

\section{Reliability Statistics}

\begin{tabular}{|ll|r|r|}
\hline arch_form & tro_width & $\begin{array}{c}\text { Cronbach's } \\
\text { Alpha(a) }\end{array}$ & N of Items \\
\hline CUSTOMIZED & 10 & .447 & 2 \\
& 20 & .305 & 2 \\
& 40 & -.032 & 2 \\
AVERAGE & 10 & .938 & 2 \\
& 20 & .832 & 2 \\
& 40 & .681 & 2 \\
\hline
\end{tabular}

a The value is negative due to a negative average covariance among items. This violates reliability model assumptions. You may want to check item codings.

Intraclass Correlation Coefficient

\begin{tabular}{|c|c|c|c|c|c|c|c|c|c|}
\hline \multirow[b]{2}{*}{ arch_form } & \multirow[b]{2}{*}{ tro_width } & & \multirow[b]{2}{*}{$\begin{array}{c}\text { Intraclass } \\
\text { Correlation(a) }\end{array}$} & \multicolumn{2}{|c|}{$\begin{array}{l}95 \% \text { Confidence } \\
\text { Interval }\end{array}$} & \multicolumn{4}{|c|}{ F Test with True Value 0} \\
\hline & & & & $\begin{array}{l}\text { Upper } \\
\text { Bound }\end{array}$ & Value & df1 & $d f 2$ & Sig & $\begin{array}{l}\text { Lower } \\
\text { Bound }\end{array}$ \\
\hline \multirow[t]{6}{*}{ CUSTOMIZED } & 10 & $\begin{array}{l}\text { Single } \\
\text { Measures }\end{array}$ & $.288(b)$ & -.166 & .641 & 1.808 & 19 & 19 & .103 \\
\hline & & $\begin{array}{l}\text { Average } \\
\text { Measures }\end{array}$ & $.447(c)$ & -.397 & .781 & 1.808 & 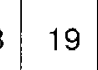 & 19 & .103 \\
\hline & 20 & $\begin{array}{l}\text { Single } \\
\text { Measures }\end{array}$ & $.180(\mathrm{~b})$ & -.274 & .569 & 1.440 & 19 & 19 & .217 \\
\hline & & $\begin{array}{l}\text { Average } \\
\text { Measures }\end{array}$ & $.305(c)$ & -.755 & .725 & 1.440 & 19 & 19 & .217 \\
\hline & 40 & $\begin{array}{l}\text { Single } \\
\text { Measures }\end{array}$ & $-.016(b)$ & -.446 & .420 & .969 & 19 & 19 & .527 \\
\hline & & $\begin{array}{l}\text { Average } \\
\text { Measures }\end{array}$ & $.032(\mathrm{c})$ & -1.607 & .592 & .969 & 19 & 19 & .527 \\
\hline AVERAGE & 10 & $\begin{array}{l}\text { Single } \\
\text { Measures }\end{array}$ & $.883(b)$ & .728 & .952 & 16.033 & $\begin{array}{l}319 \\
3\end{array}$ & 19 & .000 \\
\hline
\end{tabular}




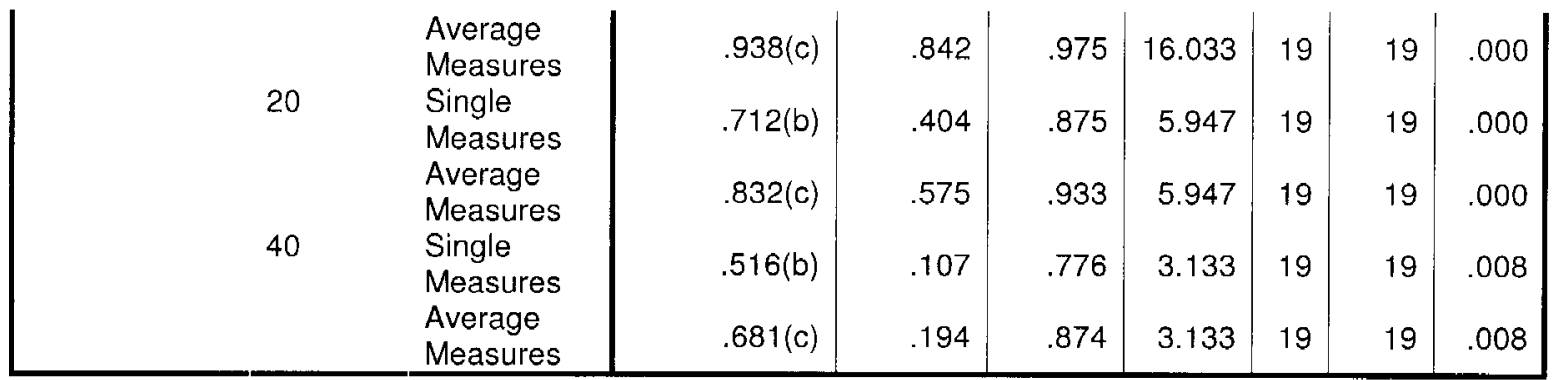

Two-way mixed effects model where people effects are random and measures effects are fixed.

a Type $C$ intraclass correlation coefficients using a consistency definition-the between-measure variance is excluded from the denominator variance.

$\mathrm{b}$ The estimator is the same, whether the interaction effect is present or not.

c This estimate is computed assuming the interaction effect is absent, because it is not estimable otherwise. 


\section{Reliability--TWO RATERS--MEASUREMENT GROUP ORIGINAL Notes}

[Dataset 1$]$

\section{Scale: ALL VARIABLES}

Case Processing Summary

\begin{tabular}{|ll|r|r|}
\hline & $\mathrm{N}$ & \multicolumn{1}{|c|}{$\%$} \\
\hline Cases & Valid & 20 & 100.0 \\
& Excluded & 0 & .0 \\
a) & 20 & 100.0 \\
\hline
\end{tabular}

a Listwise deletion based on all variables in the procedure.

\section{Reliability Statistics}

\begin{tabular}{|r|r|}
\hline $\begin{array}{c}\text { Cronbach's } \\
\text { Alpha }\end{array}$ & N of Items \\
\hline .718 & 2 \\
\hline
\end{tabular}

Intraclass Correlation Coefficient

\begin{tabular}{|c|c|c|c|c|c|c|c|c|c|}
\hline & \multirow[b]{2}{*}{$\begin{array}{l}\text { Intraclass } \\
\text { Correlation }\end{array}$} & \multicolumn{2}{|c|}{$95 \%$ Confidence Interval } & \multicolumn{6}{|c|}{ F Test with True Value 0} \\
\hline & & $\begin{array}{l}\text { Upper } \\
\text { Bound }\end{array}$ & Value & df1 & $\mathrm{df2}$ & & Sig & & $\begin{array}{l}\text { Lower } \\
\text { Bound }\end{array}$ \\
\hline Single Measures & .465 & .049 & .746 & 2.737 & & 19 & & 20 & .015 \\
\hline $\begin{array}{l}\text { Average } \\
\text { Measures }\end{array}$ & .635 & .093 & .854 & 2.737 & & 19 & & 20 & .015 \\
\hline
\end{tabular}

One-way random effects model where people effects are random.

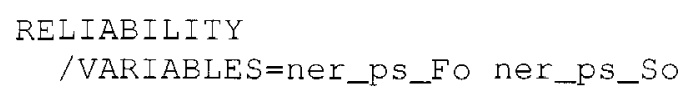


/SCALE('ALL VARIABLES') ALL/MODEL=ALPHA

/ICC=MODEL (ONEWAY) CIN=95 TESTVAL=0 .

\section{Reliability--TWO RATERS--NERVE POSITION ORIGINAL}

Notes

[Dataset 1]

\section{Scale: ALL VARIABLES}

Case Processing Summary

\begin{tabular}{|rl|r|r|}
\hline & & N & \multicolumn{1}{|c|}{$\%$} \\
\hline Cases & Valid & 20 & 100.0 \\
& Excluded & 0 & .0 \\
a) & 20 & 100.0 \\
\hline
\end{tabular}

a Listwise deletion based on all variables in the procedure.

\section{Reliability Statistics}

\begin{tabular}{|r|r|}
\hline $\begin{array}{c}\text { Cronbach's } \\
\text { Alpha }\end{array}$ & N of ltems \\
\hline .739 & 2 \\
\hline
\end{tabular}

Intraclass Correlation Coefficient

\begin{tabular}{|c|c|c|c|c|c|c|c|c|c|}
\hline & \multirow[b]{2}{*}{$\begin{array}{l}\text { Intraclass } \\
\text { Correlation }\end{array}$} & \multicolumn{2}{|c|}{$95 \%$ Confidence Interval } & \multicolumn{6}{|c|}{ F Test with True Value 0} \\
\hline & & $\begin{array}{l}\text { Upper } \\
\text { Bound }\end{array}$ & Value & df1 & $\mathrm{dt} 2$ & & Sig & & $\begin{array}{l}\text { Lower } \\
\text { Bound }\end{array}$ \\
\hline Single Measures & .470 & .056 & .749 & 2.776 & & 19 & & 20 & .014 \\
\hline $\begin{array}{l}\text { Average } \\
\text { Measures }\end{array}$ & .640 & .106 & .856 & 2.776 & & 19 & & 20 & .014 \\
\hline
\end{tabular}

One-way random effects model where people effects are random.

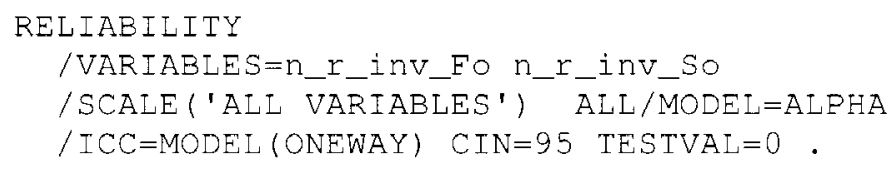

Reliability--TWO RATERS--NERVE TO ROOT ASSOC ORIGINAL 
Notes

[Dataset 1$]$

\section{Scale: ALL VARIABLES}

\section{Case Processing Summary}

\begin{tabular}{|ll|r|r|}
\hline & & $\mathrm{N}$ & \multicolumn{1}{|c|}{$\%$} \\
\hline Cases & Valid & 20 & 100.0 \\
& Excluded( & 0 & .0 \\
& a) & 20 & 100.0 \\
\hline
\end{tabular}

a Listwise deletion based on all variables in the procedure.

\section{Reliability Statistics}

\begin{tabular}{|r|r|}
\hline $\begin{array}{c}\text { Cronbach's } \\
\text { Alpha }\end{array}$ & N of Items \\
\hline .557 & 2 \\
\hline
\end{tabular}

Intraclass Correlation Coefficient

\begin{tabular}{|c|c|c|c|c|c|c|c|c|c|}
\hline & \multirow[b]{2}{*}{$\begin{array}{l}\text { Intraclass } \\
\text { Correlation }\end{array}$} & \multicolumn{2}{|c|}{$95 \%$ Confidence Interval } & \multicolumn{6}{|c|}{ F Test with True Value 0} \\
\hline & & $\begin{array}{l}\text { Upper } \\
\text { Bound }\end{array}$ & Value & $\mathrm{df} 1$ & $\mathrm{df} 2$ & & Sig & & $\begin{array}{l}\text { Lower } \\
\text { Bound }\end{array}$ \\
\hline Single Measures & .337 & -.103 & .670 & 2.018 & & 19 & & 20 & .064 \\
\hline $\begin{array}{l}\text { Average } \\
\text { Measures }\end{array}$ & .504 & -.230 & .802 & 2.018 & & 19 & & 20 & .064 \\
\hline
\end{tabular}

One-way random effects model where people effects are random.

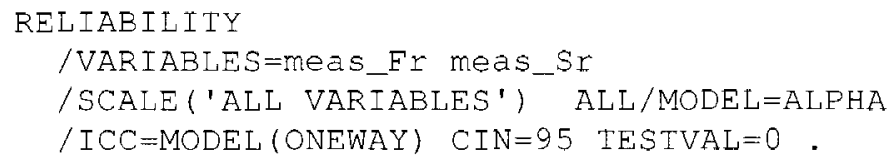

Reliability--TWO RATERS--MEASUREMENT GROUP REPEAT

Notes 
[Dataset 1$]$

\section{Scale: ALL VARIABLES}

\section{Case Processing Summary}

\begin{tabular}{|ll|r|r|}
\hline & & \multicolumn{1}{|c|}{$\mathrm{N}$} & \multicolumn{1}{c|}{$\%$} \\
\hline Cases & Valid & 20 & 100.0 \\
& Excluded & 0 & .0 \\
& a) & & 100.0 \\
\hline
\end{tabular}

a Listwise deletion based on all variables in the procedure.

\section{Reliability Statistics}

\begin{tabular}{|r|r|}
\hline $\begin{array}{c}\text { Cronbach's } \\
\text { Alpha }\end{array}$ & N of ltems \\
\hline .338 & 2 \\
\hline
\end{tabular}

Intraclass Correlation Coefficient

\begin{tabular}{|c|c|c|c|c|c|c|c|c|c|}
\hline & \multirow[b]{2}{*}{$\begin{array}{l}\text { Intraclass } \\
\text { Correlation }\end{array}$} & \multicolumn{2}{|c|}{$95 \%$ Confidence Interval } & \multicolumn{6}{|c|}{ F Test with True Value 0} \\
\hline & & $\begin{array}{l}\text { Upper } \\
\text { Bound }\end{array}$ & Value & df1 & $\mathrm{df} 2$ & & Sig & & $\begin{array}{l}\text { Lower } \\
\text { Bound }\end{array}$ \\
\hline Single Measures & .218 & -.229 & .593 & 1.558 & & 19 & & 20 & .167 \\
\hline $\begin{array}{l}\text { Average } \\
\text { Measures }\end{array}$ & .358 & -.593 & .744 & 1.558 & & 19 & & 20 & 167 \\
\hline
\end{tabular}

One-way random effects model where people effects are random.

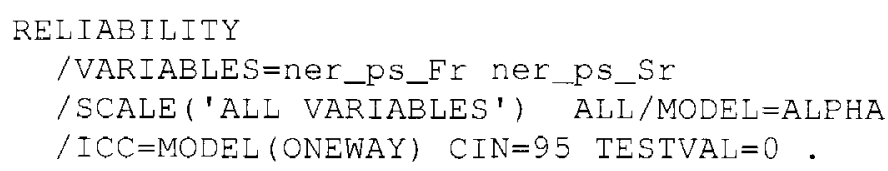

\section{Reliability--TWO RATERS--NERVE POSITION REPEAT}

\section{Notes}

[Dataset 1]

\section{Scale: ALL VARIABLES}




\section{Case Processing Summary}

\begin{tabular}{|rl|r|r|}
\hline & & $\mathrm{N}$ & \multicolumn{1}{|c|}{$\%$} \\
\hline Cases & Valid & 20 & 100.0 \\
& Excluded( & 0 & .0 \\
a) & 20 & 100.0 \\
\hline
\end{tabular}

a Listwise deletion based on all variables in the procedure.

\section{Reliability Statistics}

\begin{tabular}{|r|r|}
\hline $\begin{array}{c}\text { Cronbach's } \\
\text { Alpha }\end{array}$ & N of Items \\
\hline .857 & 2 \\
\hline
\end{tabular}

Intraclass Correlation Coefficient

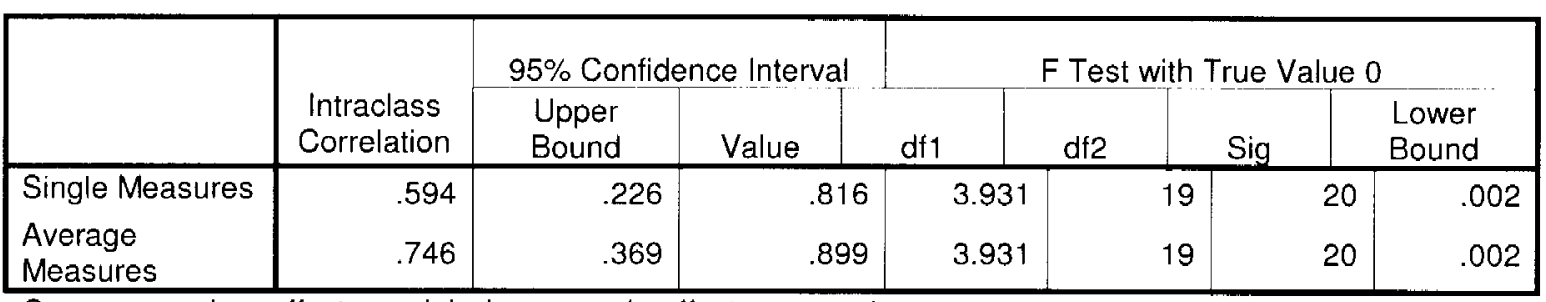

One-way random effects model where people effects are random.

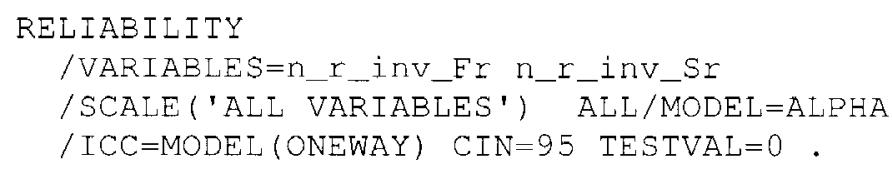

\section{Reliability--TWO RATERS--NERVE TO ROOT ASSOC REPEAT}

\section{Notes}

[Dataset 1]

\section{Scale: ALL VARIABLES}

\section{Case Processing Summary}

\begin{tabular}{|l|l|l|}
\hline & $N$ & $\%$ \\
\hline
\end{tabular}




\begin{tabular}{|ll|r|r|}
\hline Cases & Valid & 20 & 100.0 \\
& Excluded & 0 & .0 \\
a) & 0 & 100.0 \\
\hline
\end{tabular}

a Listwise deletion based on all variables in the procedure.

\section{Reliability Statistics}

\begin{tabular}{|r|r|}
\hline $\begin{array}{c}\text { Cronbach's } \\
\text { Alpha }\end{array}$ & N of Items \\
\hline .780 & 2 \\
\hline
\end{tabular}

Intraclass Correlation Coefficient

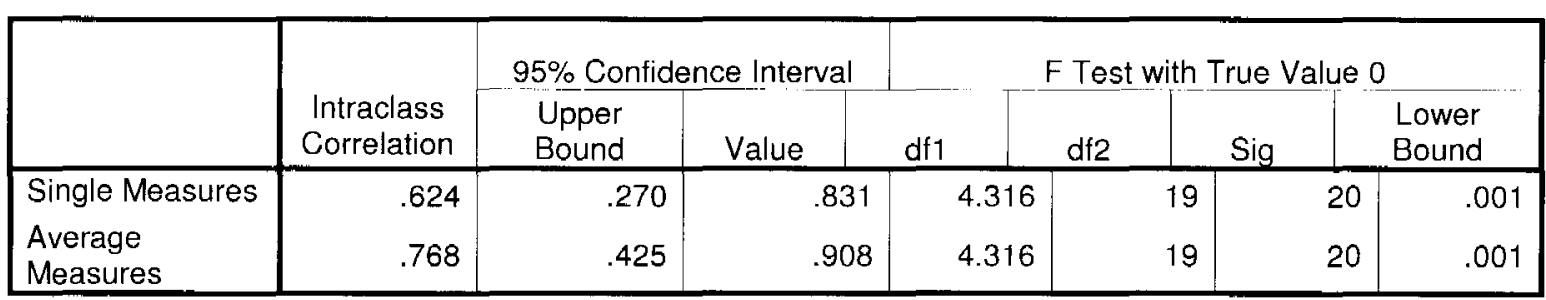

One-way random effects model where people effects are random. 
Appendix D- Intra-rater reliability

\section{Reliability--FARMAN--MEASUREMENT GROUP}

\section{Notes}

[DataSet1]

Scale: ALL VARIABLES

Case Processing Summary

\begin{tabular}{|rl|r|r|}
\hline & & N & \multicolumn{1}{|c|}{$\%$} \\
\hline Cases & Valid & 20 & 100.0 \\
& Excluded & 0 & .0 \\
a) & 20 & 100.0 \\
\hline
\end{tabular}

a Listwise deletion based on all variables in the procedure.

\section{Reliability Statistics}

\begin{tabular}{|r|r|}
\hline $\begin{array}{c}\text { Cronbach's } \\
\text { Alpha }\end{array}$ & N of Items \\
\hline .628 & 2 \\
\hline
\end{tabular}

Intraclass Correlation Coefficient

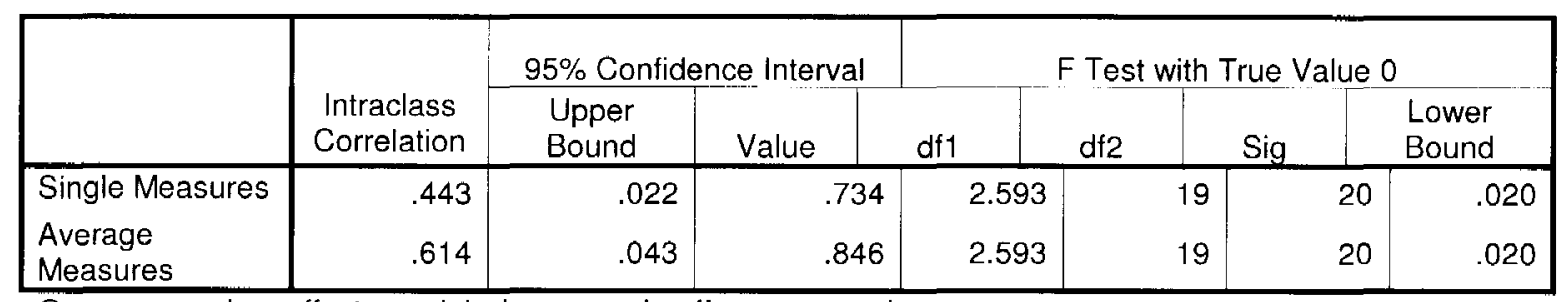

One-way random effects model where people effects are random.

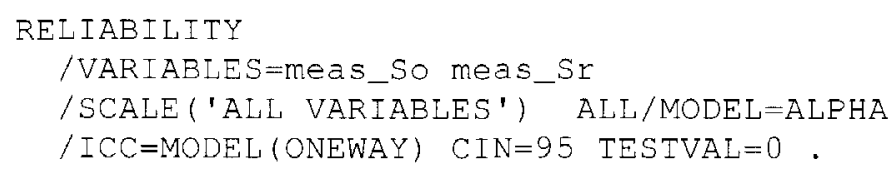




\title{
Reliability--CHANDIRMANI--MEASUREMENT GROUP
}

\author{
Notes
}

[Dataset 1]

Scale: ALL VARIABLES

Case Processing Summary

\begin{tabular}{|ll|r|r|}
\hline & N & \multicolumn{1}{|c|}{$\%$} \\
\hline Cases & Valid & 20 & 100.0 \\
& Excluded & 0 & .0 \\
a) & 20 & 100.0 \\
\hline
\end{tabular}

a Listwise deletion based on all variables in the procedure.

Reliability Statistics

\begin{tabular}{|r|r|}
\hline $\begin{array}{c}\text { Cronbach's } \\
\text { Alpha }\end{array}$ & N of ltems \\
\hline .927 & 2 \\
\hline
\end{tabular}

Intraclass Correlation Coefficient

\begin{tabular}{|c|c|c|c|c|c|c|c|c|c|}
\hline & \multirow[b]{2}{*}{$\begin{array}{l}\text { Intraclass } \\
\text { Correlation }\end{array}$} & \multicolumn{2}{|c|}{$95 \%$ Confidence Interval } & \multicolumn{6}{|c|}{ F Test with True Value 0} \\
\hline & & $\begin{array}{l}\text { Upper } \\
\text { Bound }\end{array}$ & Value & df1 & $d f 2$ & & $\mathrm{Sig}$ & & $\begin{array}{l}\text { Lower } \\
\text { Bound }\end{array}$ \\
\hline Single Measures & .863 & .692 & .943 & 13.632 & & 19 & & 20 & .000 \\
\hline $\begin{array}{l}\text { Average } \\
\text { Measures }\end{array}$ & .927 & .818 & .971 & 13.632 & & 19 & & 20 & .000 \\
\hline
\end{tabular}

One-way random effects model where people effects are random.

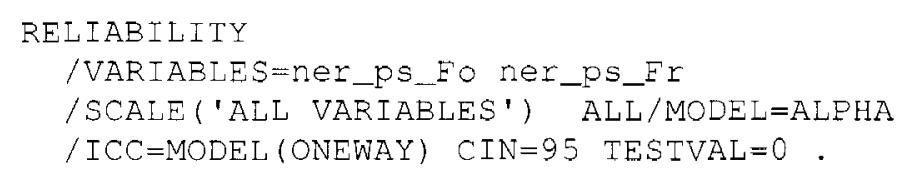

\section{Reliability--FARMAN--NERVE POSITION}

\section{Notes}


[Dataset 1$]$

\section{Scale: ALL VARIABLES}

\section{Case Processing Summary}

\begin{tabular}{|ll|r|r|}
\hline & $N$ & \multicolumn{1}{|c|}{$\%$} \\
\hline Cases & Valid & 20 & 100.0 \\
& Excluded & & .0 \\
a) & 0 & 100.0 \\
\hline
\end{tabular}

a Listwise deletion based on all variables in the procedure.

\section{Reliability Statistics}

\begin{tabular}{|r|r|}
\hline $\begin{array}{c}\text { Cronbach's } \\
\text { Alpha }\end{array}$ & N of Items \\
\hline .771 & 2 \\
\hline
\end{tabular}

Intraclass Correlation Coefficient

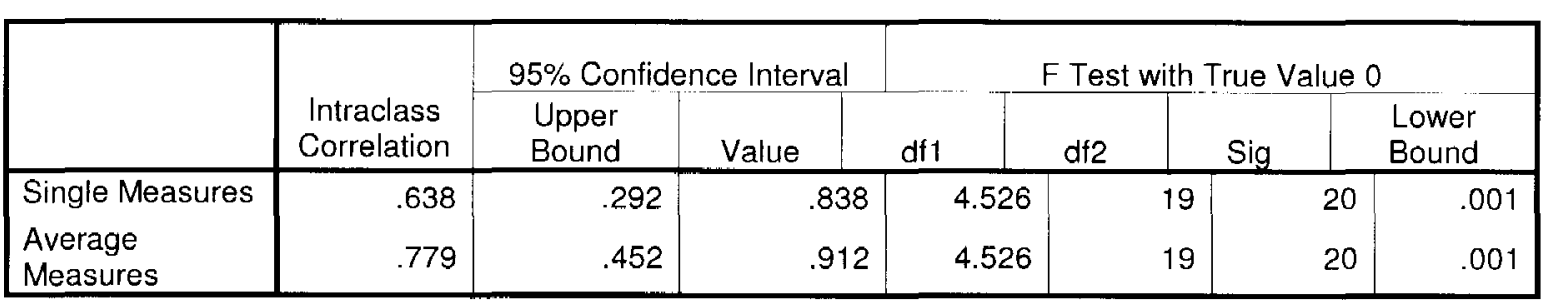

One-way random effects model where people effects are random.

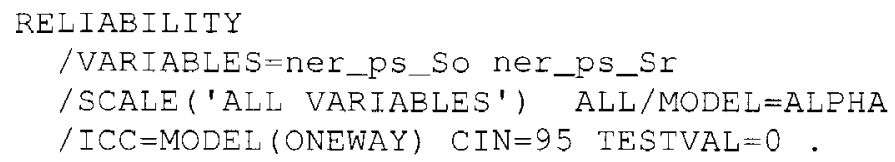

\section{Reliability--CHANDIRMANI--NERVE POSITION}

\section{Notes}

[Dataset 1] 


\section{Scale: ALL VARIABLES}

\section{Case Processing Summary}

\begin{tabular}{|ll|r|r|}
\hline & & $\mathrm{N}$ & \multicolumn{1}{|c|}{$\%$} \\
\hline Cases & Valid & 20 & 100.0 \\
& Excluded( & 0 & .0 \\
& a) & 20 & 100.0 \\
\hline
\end{tabular}

a Listwise deletion based on all variables in the procedure.

Reliability Statistics

\begin{tabular}{|r|r|}
\hline $\begin{array}{c}\text { Cronbach's } \\
\text { Alpha }\end{array}$ & N of Items \\
\hline .972 & 2 \\
\hline
\end{tabular}

Intraclass Correlation Coefficient

\begin{tabular}{|c|c|c|c|c|c|c|c|c|c|c|}
\hline & \multirow[b]{2}{*}{$\begin{array}{l}\text { Intraclass } \\
\text { Correlation }\end{array}$} & \multicolumn{3}{|c|}{$95 \%$ Confidence Interval } & \multicolumn{6}{|c|}{ F Test with True Value 0} \\
\hline & & $\begin{array}{l}\text { Upper } \\
\text { Bound } \\
\end{array}$ & Value & df1 & & $1 f 2$ & & Sig & & $\begin{array}{l}\text { Lower } \\
\text { Bound }\end{array}$ \\
\hline Single Measures & .945 & .869 & & & & & 19 & & 20 & .000 \\
\hline $\begin{array}{l}\text { Average } \\
\text { Measures }\end{array}$ & .972 & .930 & & & & & 19 & & 20 & .000 \\
\hline
\end{tabular}

One-way random effects model where people effects are random.

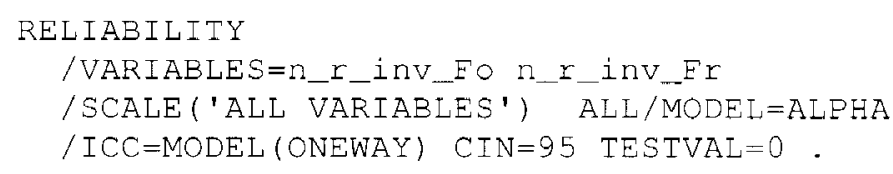

Reliability--FARMAN--NERVE TO ROOT ASSOC

\section{Notes}

[Dataset 1$]$

\section{Scale: ALL VARIABLES}

\section{Case Processing Summary}




\begin{tabular}{|rl|r|r|}
\hline & & N & \multicolumn{1}{|c|}{$\%$} \\
\hline Cases & Valid & 20 & 100.0 \\
& Excluded & & .0 \\
a) & 0 & 100.0 \\
\hline
\end{tabular}

a Listwise deletion based on all variables in the procedure.

Reliability Statistics

\begin{tabular}{|r|r|}
\hline $\begin{array}{c}\text { Cronbach's } \\
\text { Alpha }\end{array}$ & N of Items \\
\hline .791 & 2 \\
\hline
\end{tabular}

Intraclass Correlation Coefficient

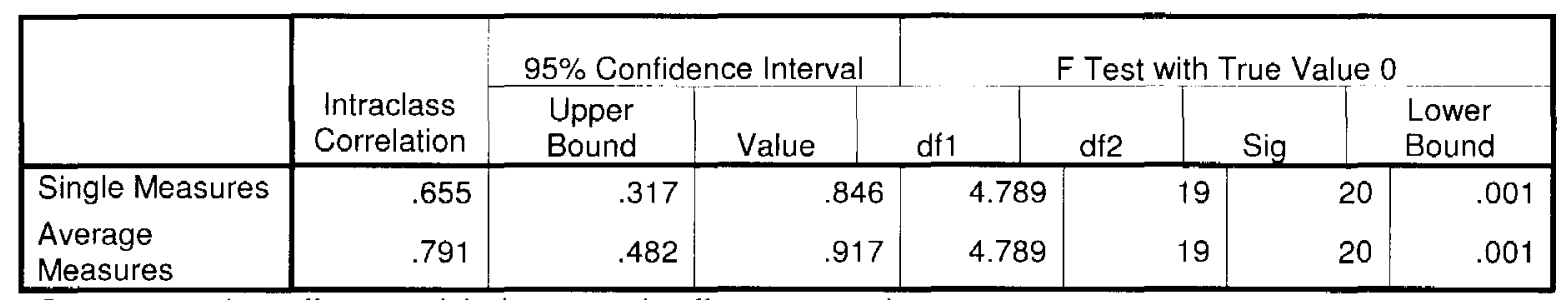

One-way random effects model where people effects are random.

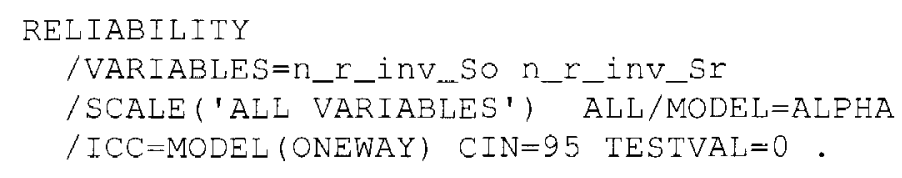

\section{Reliability--CHANDIRMANI--NERVE TO ROOT ASSOC}

\section{Notes}

\section{Scale: ALL VARIABLES}

Case Processing Summary

\begin{tabular}{|rl|r|r|}
\hline & & $\mathrm{N}$ & \multicolumn{1}{|c|}{$\%$} \\
\hline Cases & Valid & 20 & 100.0 \\
& Excluded ( & 0 & .0 \\
a) & 20 & 100.0 \\
\hline
\end{tabular}

a Listwise deletion based on all variables in the procedure. 


\section{Reliability Statistics}

\begin{tabular}{|r|r|}
\hline $\begin{array}{c}\text { Cronbach's } \\
\text { Alpha }\end{array}$ & N of Items \\
\hline 1.000 & 2 \\
\hline
\end{tabular}

Intraclass Correlation Coefficient

\begin{tabular}{|c|c|c|c|c|c|c|c|}
\hline & \multirow[b]{2}{*}{$\begin{array}{l}\text { Intraclass } \\
\text { Correlation }\end{array}$} & \multicolumn{2}{|c|}{$95 \%$ Confidence Interva } & \multicolumn{4}{|c|}{ F Test with True Value 0} \\
\hline & & $\begin{array}{l}\text { Upper } \\
\text { Bound }\end{array}$ & Value & $\mathrm{df} 1$ & $d f 2$ & Sig & $\begin{array}{l}\text { Lower } \\
\text { Bound }\end{array}$ \\
\hline Single Measures & 1.000 & 1.000 & \multicolumn{2}{|c|}{1.000} & \multicolumn{2}{|c|}{19} & \\
\hline $\begin{array}{l}\text { Average } \\
\text { Measures }\end{array}$ & 1.000 & 1.000 & \multicolumn{2}{|c|}{1.000} & \multicolumn{2}{|c|}{19} & \\
\hline
\end{tabular}

One-way random effects model where people effects are random. 


\title{
Reliability--FARMAN--SIGN 1
}

\author{
Notes
}

\section{[Dataset1] INTRA-RATER RELIABILITY FOR TWO RATERS}

\section{Scale: ALL VARIABLES}

\begin{tabular}{|c|c|c|c|c|c|}
\hline \multicolumn{6}{|c|}{ Case Processing Summary } \\
\hline arch form & tro width & & & $\mathrm{N}$ & $\%$ \\
\hline \multirow[t]{9}{*}{ CUSTOMIZED } & 10 & Cases & Valid & 20 & 100.0 \\
\hline & & & $\begin{array}{l}\text { Excluded( } \\
\text { a) }\end{array}$ & 0 & .0 \\
\hline & & & Total & 20 & 100.0 \\
\hline & 20 & Cases & Valid & 20 & 100.0 \\
\hline & & & $\begin{array}{l}\text { Excluded( } \\
\text { a) }\end{array}$ & 0 & .0 \\
\hline & & & Total & 20 & 100.0 \\
\hline & 40 & Cases & Valid & 20 & 100.0 \\
\hline & & & $\begin{array}{l}\text { Excluded( } \\
\text { a) }\end{array}$ & 0 & .0 \\
\hline & & & Total & 20 & 100.0 \\
\hline \multirow[t]{9}{*}{ AVERAGE } & 10 & Cases & Valid & 20 & 100.0 \\
\hline & & & $\begin{array}{l}\text { Excluded( } \\
\text { a) }\end{array}$ & 0 & .0 \\
\hline & & & Total & 20 & 100.0 \\
\hline & 20 & Cases & Valid & 20 & 100.0 \\
\hline & & & $\begin{array}{l}\text { Excluded( } \\
\text { a) }\end{array}$ & 0 & .0 \\
\hline & & & Total & 20 & 100.0 \\
\hline & 40 & Cases & Valid & 20 & 100.0 \\
\hline & & & $\begin{array}{l}\text { Excluded( } \\
\text { a) }\end{array}$ & 0 & .0 \\
\hline & & & Total & 20 & 100.0 \\
\hline
\end{tabular}

a Listwise deletion based on all variables in the procedure. 
Reliability Statistics

\begin{tabular}{|ll|r|r|}
\hline arch_form & tro_width & \multicolumn{1}{c|}{$\begin{array}{c}\text { Cronbach's } \\
\text { Alpha }\end{array}$} & N of Items \\
\hline CUSTOMIZED & 10 & .877 & 2 \\
& 20 & .590 & 2 \\
& 40 & .511 & 2 \\
AVERAGE & 10 & .881 & 2 \\
& 20 & .831 & 2 \\
& 40 & .676 & 2 \\
\hline
\end{tabular}

Intraclass Correlation Coefficient

\begin{tabular}{|c|c|c|c|c|c|c|c|c|c|}
\hline \multirow[b]{2}{*}{ arch form } & \multirow[b]{2}{*}{ tro_width } & & \multirow[b]{2}{*}{$\begin{array}{l}\text { Intraclass } \\
\text { Correlation }\end{array}$} & \multicolumn{2}{|c|}{$\begin{array}{c}95 \% \text { Confidence } \\
\text { Interval }\end{array}$} & \multicolumn{4}{|c|}{$\mathrm{F}$ Test with True Value 0} \\
\hline & & & & $\begin{array}{l}\text { Upper } \\
\text { Bound }\end{array}$ & Value & df1 & $\mathrm{df} 2$ & Sig & $\begin{array}{l}\text { Lower } \\
\text { Bound }\end{array}$ \\
\hline \multirow[t]{6}{*}{ CUSTOMIZED } & 10 & $\begin{array}{l}\text { Single } \\
\text { Measures }\end{array}$ & .790 & .549 & .911 & 8.526 & 19 & 20 & .000 \\
\hline & & $\begin{array}{l}\text { Average } \\
\text { Measures }\end{array}$ & .883 & .709 & .953 & 8.526 & 19 & 20 & .000 \\
\hline & 20 & $\begin{array}{l}\text { Single } \\
\text { Measures }\end{array}$ & .436 & .013 & .730 & 2.549 & 19 & 20 & .022 \\
\hline & & $\begin{array}{l}\text { Average } \\
\text { Measures }\end{array}$ & .608 & .026 & .844 & 2.549 & 19 & 20 & .022 \\
\hline & 40 & $\begin{array}{l}\text { Single } \\
\text { Measures }\end{array}$ & .364 & -.073 & .686 & 2.144 & 19 & 20 & .049 \\
\hline & & $\begin{array}{l}\text { Average } \\
\text { Measures }\end{array}$ & .534 & -.158 & .814 & 2.144 & 19 & 20 & .049 \\
\hline \multirow[t]{6}{*}{ AVERAGE } & 10 & $\begin{array}{l}\text { Single } \\
\text { Measures }\end{array}$ & .784 & .538 & .908 & 8.263 & 19 & 20 & .000 \\
\hline & & $\begin{array}{l}\text { Average } \\
\text { Measures }\end{array}$ & .879 & .700 & .952 & 8.263 & 19 & 20 & .000 \\
\hline & 20 & $\begin{array}{l}\text { Single } \\
\text { Measures }\end{array}$ & .717 & .420 & .877 & 6.079 & 19 & 20 & .000 \\
\hline & & $\begin{array}{l}\text { Average } \\
\text { Measures }\end{array}$ & .835 & .592 & .934 & 6.079 & 19 & 20 & .000 \\
\hline & 40 & $\begin{array}{l}\text { Single } \\
\text { Measures }\end{array}$ & .485 & .074 & .757 & 2.882 & 19 & 20 & .012 \\
\hline & & $\begin{array}{l}\text { Average } \\
\text { Measures }\end{array}$ & .653 & .139 & .862 & 2.882 & 19 & 20 & .012 \\
\hline
\end{tabular}

One-way random effects model where people effects are random.

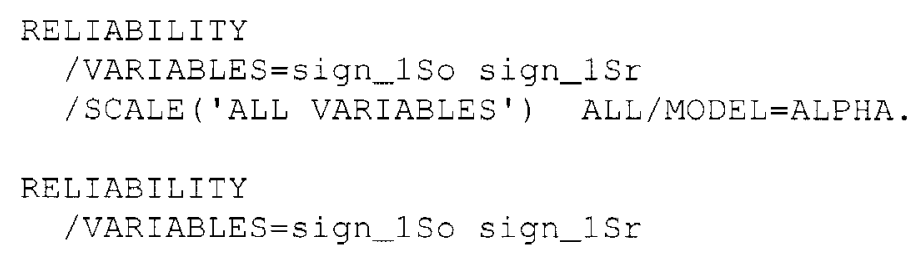


/SCALE('ALL VARIABLES') ALI/MODEL=ALPHA

/ ICC $=$ MODEL (ONEWAY) CIN=95 TESTVAL=0 .

\section{Reliability--CHANDIRMANI--SIGN 1}

\section{Notes}

[Dataset 1]

\section{Scale: ALL VARIABLES}

Case Processing Summary

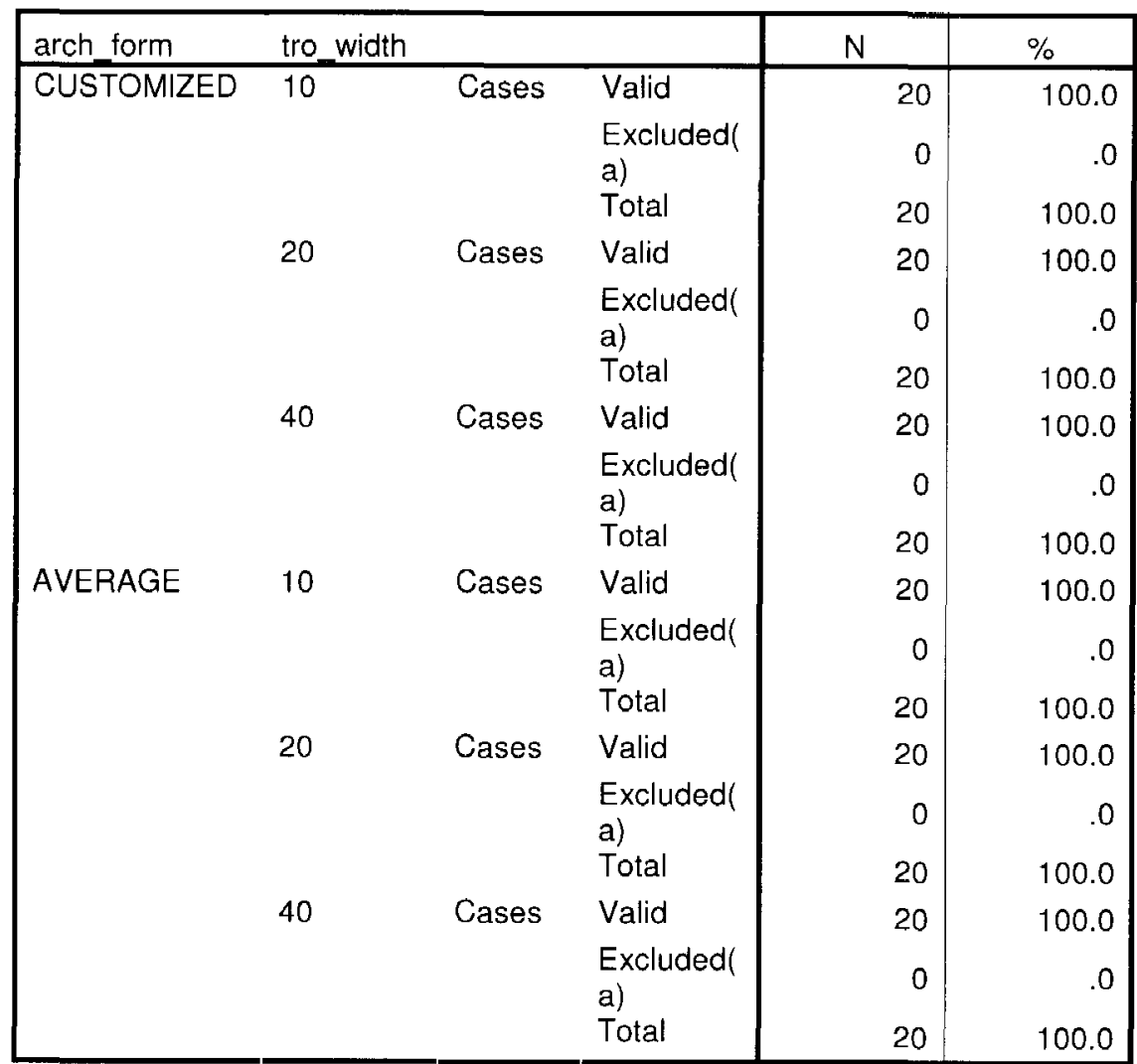

a Listwise deletion based on all variables in the procedure.

\section{Reliability Statistics}

\begin{tabular}{|ll|l|l|}
\hline arch form $\quad$ tro width & $\begin{array}{c}\text { Cronbach's } \\
\text { Alpha(a) }\end{array}$ & N of Items \\
\hline
\end{tabular}




\begin{tabular}{|ll|r|r|}
\hline CUSTOMIZED & 10 & .654 & 2 \\
& 20 & -.264 & 2 \\
& 40 & .516 & 2 \\
AVERAGE & 10 & .889 & 2 \\
& 20 & .331 & 2 \\
& 40 & -.148 & 2 \\
\hline
\end{tabular}

a The value is negative due to a negative average covariance among items. This violates reliability model assumptions. You may want to check item codings.

Intraclass Correlation Coefficient

\begin{tabular}{|c|c|c|c|c|c|c|c|c|c|}
\hline \multirow[b]{2}{*}{ arch_form } & \multirow[b]{2}{*}{ tro_width } & & \multirow[b]{2}{*}{$\begin{array}{l}\text { Intraclass } \\
\text { Correlation }\end{array}$} & \multicolumn{2}{|c|}{$\begin{array}{l}95 \% \text { Confidence } \\
\text { Interval }\end{array}$} & \multicolumn{4}{|c|}{ F Test with True Value 0} \\
\hline & & & & $\begin{array}{l}\text { Upper } \\
\text { Bound }\end{array}$ & Value & df1 & $\mathrm{df} 2$ & Sig & $\begin{array}{l}\text { Lower } \\
\text { Bound }\end{array}$ \\
\hline \multirow[t]{6}{*}{ CUSTOMIZED } & 10 & $\begin{array}{l}\text { Single } \\
\text { Measures }\end{array}$ & .465 & .049 & .746 & 2.737 & 19 & 20 & .015 \\
\hline & & $\begin{array}{l}\text { Average } \\
\text { Measures }\end{array}$ & .635 & .093 & .854 & 2.737 & 19 & 20 & .015 \\
\hline & 20 & $\begin{array}{l}\text { Single } \\
\text { Measures }\end{array}$ & -.188 & -.568 & .264 & .684 & 19 & 20 & .794 \\
\hline & & $\begin{array}{l}\text { Average } \\
\text { Measures }\end{array}$ & -.462 & -2.628 & .417 & .684 & 19 & 20 & .794 \\
\hline & 40 & $\begin{array}{l}\text { Single } \\
\text { Measures }\end{array}$ & .255 & -.192 & .617 & 1.684 & 19 & 20 & .128 \\
\hline & & $\begin{array}{l}\text { Average } \\
\text { Measures }\end{array}$ & .406 & -.474 & .763 & 1.684 & 19 & 20 & .128 \\
\hline \multirow[t]{6}{*}{ AVERAGE } & 10 & $\begin{array}{l}\text { Single } \\
\text { Measures }\end{array}$ & .753 & .482 & .894 & 7.105 & 19 & 20 & .000 \\
\hline & & $\begin{array}{l}\text { Average } \\
\text { Measures }\end{array}$ & .859 & .651 & .944 & 7.105 & 19 & 20 & .000 \\
\hline & 20 & $\begin{array}{l}\text { Single } \\
\text { Measures }\end{array}$ & .172 & -.274 & .561 & 1.415 & 19 & 20 & .224 \\
\hline & & $\begin{array}{l}\text { Average } \\
\text { Measures }\end{array}$ & .293 & -.754 & .718 & 1.415 & 19 & 20 & .224 \\
\hline & 40 & $\begin{array}{l}\text { Single } \\
\text { Measures }\end{array}$ & -.071 & -.482 & .370 & .867 & 19 & 20 & .620 \\
\hline & & $\begin{array}{l}\text { Average } \\
\text { Measures }\end{array}$ & -.153 & -1.862 & .540 & .867 & 19 & 20 & .620 \\
\hline
\end{tabular}

One-way random effects model where people effects are random.

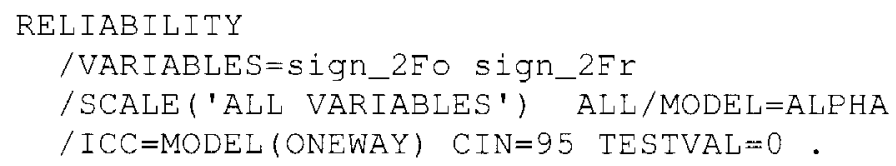

\section{Reliability--FARMAN--SIGN 2}

Notes 
[Dataset1]

\section{Scale: ALL VARIABLES}

Case Processing Summary

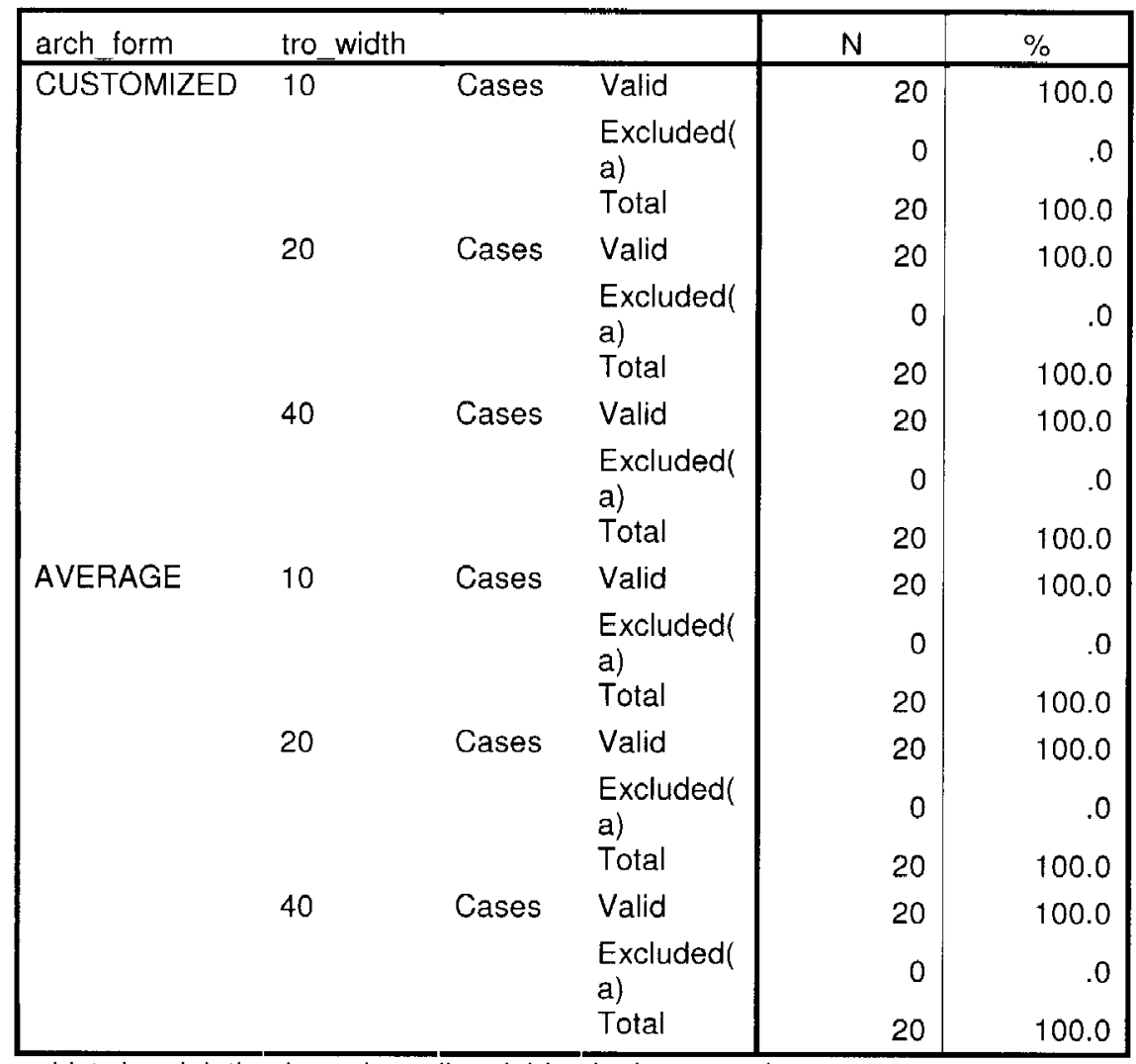

a Listwise deletion based on all variables in the procedure.

Reliability Statistics

\begin{tabular}{|ll|r|r|}
\hline arch form & tro width & $\begin{array}{c}\text { Cronbach's } \\
\text { Alpha }\end{array}$ & N of Items \\
\hline CUSTOMIZED & 10 & .508 & 2 \\
& 20 & .733 & 2 \\
& 40 & .718 & 2 \\
AVERAGE & 10 & .901 & 2 \\
& 20 & .719 & 2 \\
\hline
\end{tabular}




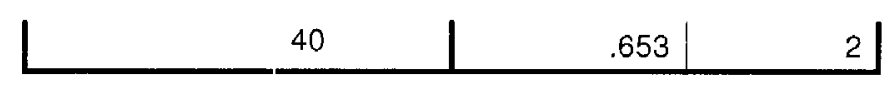

Intraclass Correlation Coefficient

\begin{tabular}{|c|c|c|c|c|c|c|c|c|c|}
\hline \multirow[b]{2}{*}{ arch_form } & \multirow[b]{2}{*}{ tro_width } & & \multirow[b]{2}{*}{$\begin{array}{l}\text { Intraclass } \\
\text { Correlation }\end{array}$} & \multicolumn{2}{|c|}{$\begin{array}{c}95 \% \text { Confidence } \\
\text { Interval }\end{array}$} & \multicolumn{4}{|c|}{ F Test with True Value 0} \\
\hline & & & & $\begin{array}{l}\text { Upper } \\
\text { Bound }\end{array}$ & Value & df1 & $\mathrm{df} 2$ & Sig & $\begin{array}{l}\text { Lower } \\
\text { Bound }\end{array}$ \\
\hline \multirow[t]{6}{*}{ CUSTOMIZED } & 10 & $\begin{array}{l}\text { Single } \\
\text { Measures }\end{array}$ & .363 & -.074 & .686 & 2.140 & 19 & 20 & .050 \\
\hline & & $\begin{array}{l}\text { Average } \\
\text { Measures }\end{array}$ & .533 & -.160 & .814 & 2.140 & 19 & 20 & .050 \\
\hline & 20 & $\begin{array}{l}\text { Single } \\
\text { Measures }\end{array}$ & .592 & .223 & .815 & 3.905 & 19 & 20 & .002 \\
\hline & & $\begin{array}{l}\text { Average } \\
\text { Measures }\end{array}$ & .744 & .364 & .898 & 3.905 & 19 & 20 & .002 \\
\hline & 40 & $\begin{array}{l}\text { Single } \\
\text { Measures }\end{array}$ & .571 & .192 & .804 & 3.663 & 19 & 20 & .003 \\
\hline & & $\begin{array}{l}\text { Average } \\
\text { Measures }\end{array}$ & .727 & .322 & .891 & & 19 & 20 & .003 \\
\hline \multirow[t]{6}{*}{ AVERAGE } & 10 & $\begin{array}{l}\text { Single } \\
\text { Measures }\end{array}$ & 823 & .612 & .926 & 10.316 & 19 & 20 & .000 \\
\hline & & $\begin{array}{l}\text { Average } \\
\text { Measures }\end{array}$ & .903 & .759 & .961 & 10.316 & 19 & 20 & .000 \\
\hline & 20 & $\begin{array}{l}\text { Single } \\
\text { Measures }\end{array}$ & .577 & .201 & .807 & 3.727 & 19 & 20 & .003 \\
\hline & & $\begin{array}{l}\text { Average } \\
\text { Measures }\end{array}$ & .732 & .334 & .893 & 3.727 & 19 & 20 & .003 \\
\hline & 40 & $\begin{array}{l}\text { Single } \\
\text { Measures }\end{array}$ & .495 & .087 & .762 & 2.957 & 19 & 20 & .010 \\
\hline & & $\begin{array}{l}\text { Average } \\
\text { Measures }\end{array}$ & .662 & .161 & .865 & 2.957 & 19 & 20 & .010 \\
\hline
\end{tabular}

One-way random effects model where people effects are random.

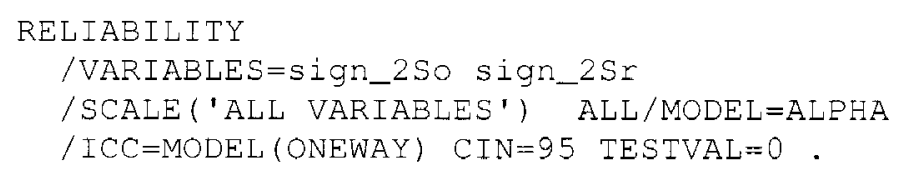

\section{Reliability--CHANDIRMANI--SIGN 2}

\section{Notes}

[Dataset 1$]$

\section{Scale: ALL VARIABLES}


Case Processing Summary

\begin{tabular}{|c|c|c|c|c|c|}
\hline arch_form & tro width & & & $\mathrm{N}$ & $\%$ \\
\hline \multirow[t]{9}{*}{ CUSTOMIZED } & 10 & Cases & Valid & 20 & 100.0 \\
\hline & & & $\begin{array}{l}\text { Excluded( } \\
\text { a) }\end{array}$ & 0 & .0 \\
\hline & & & Total & 20 & 100.0 \\
\hline & 20 & Cases & Valid & 20 & 100.0 \\
\hline & & & $\begin{array}{l}\text { Excluded( } \\
\text { a) }\end{array}$ & 0 & .0 \\
\hline & & & Total & 20 & 100.0 \\
\hline & 40 & Cases & Valid & 20 & 100.0 \\
\hline & & & $\begin{array}{l}\text { Excluded( } \\
\text { a) }\end{array}$ & 0 & .0 \\
\hline & & & Total & 20 & 100.0 \\
\hline \multirow[t]{9}{*}{ AVERAGE } & 10 & Cases & Valid & 20 & 100.0 \\
\hline & & & $\begin{array}{l}\text { Excluded( } \\
\text { a) }\end{array}$ & 0 & .0 \\
\hline & & & Total & 20 & 100.0 \\
\hline & 20 & Cases & Valid & 20 & 100.0 \\
\hline & & & $\begin{array}{l}\text { Excluded( } \\
\text { a) }\end{array}$ & 0 & .0 \\
\hline & & & Total & 20 & 100.0 \\
\hline & 40 & Cases & Valid & 20 & 100.0 \\
\hline & & & $\begin{array}{l}\text { Excluded( } \\
\text { a) }\end{array}$ & 0 & .0 \\
\hline & & & Total & 20 & 100.0 \\
\hline
\end{tabular}

a Listwise deletion based on all variables in the procedure.

Reliability Statistics

\begin{tabular}{|ll|r|r|}
\hline arch form & tro width & $\begin{array}{c}\text { Cronbach's } \\
\text { Alpha }\end{array}$ & N of Items \\
\hline CUSTOMIZED & 10 & .658 & 2 \\
& 20 & .525 & 2 \\
& 40 & .522 & 2 \\
AVERAGE & 10 & .962 & 2 \\
& 20 & .714 & 2 \\
& 40 & .545 & 2 \\
\hline
\end{tabular}

Intraclass Correlation Coefficient

\begin{tabular}{|l|c|c|c|}
\hline arch_form tro_width & $\begin{array}{c}\text { Intraclass } \\
\text { Correlation }\end{array}$ & $\begin{array}{c}95 \% \text { Confidence } \\
\text { Interval }\end{array}$ & F Test with True Value 0 \\
\hline
\end{tabular}




\begin{tabular}{|c|c|c|c|c|c|c|c|c|c|}
\hline & & & & $\begin{array}{l}\text { Upper } \\
\text { Bound }\end{array}$ & Value & $\mathrm{df} 1$ & $\mathrm{df} 2$ & Sig & $\begin{array}{l}\text { Lower } \\
\text { Bound }\end{array}$ \\
\hline \multirow[t]{8}{*}{ CUSTOMIZED } & \multirow[t]{3}{*}{10} & Single & .395 & -.037 & .705 & 2.305 & 19 & 20 & .036 \\
\hline & & Average & & & & & & & \\
\hline & & Measures & .566 & -.077 & .827 & 2.305 & 19 & 20 & .036 \\
\hline & \multirow[t]{2}{*}{20} & $\begin{array}{l}\text { Single } \\
\text { Measures }\end{array}$ & .363 & -.074 & .686 & 2.140 & 19 & 20 & .050 \\
\hline & & $\begin{array}{l}\text { Average } \\
\text { Measures }\end{array}$ & .533 & -.160 & .814 & 2.140 & 19 & 20 & .050 \\
\hline & \multirow[t]{3}{*}{40} & Single & 373 & -.063 & $69 ?$ & 2188 & 19 & 20 & 045 \\
\hline & & Measures & 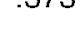 & & & 2.100 & & & .043 \\
\hline & & $\begin{array}{l}\text { Average } \\
\text { Measures }\end{array}$ & .543 & -.134 & .818 & 2.188 & 19 & 20 & .045 \\
\hline \multirow[t]{6}{*}{ AVERAGE } & \multirow[t]{2}{*}{10} & $\begin{array}{l}\text { Single } \\
\text { Measures }\end{array}$ & .931 & .837 & .972 & 27.895 & 19 & 20 & .000 \\
\hline & & $\begin{array}{l}\text { Average } \\
\text { Measures }\end{array}$ & .964 & .911 & .986 & 27.895 & 19 & 20 & .000 \\
\hline & \multirow[t]{2}{*}{20} & $\begin{array}{l}\text { Single } \\
\text { Measures }\end{array}$ & .544 & .155 & .790 & 3.389 & 19 & 20 & .005 \\
\hline & & $\begin{array}{l}\text { Average } \\
\text { Measures }\end{array}$ & .705 & .268 & .882 & 3.389 & 19 & 20 & .005 \\
\hline & \multirow[t]{2}{*}{40} & $\begin{array}{l}\text { Single } \\
\text { Measures }\end{array}$ & .345 & -.095 & .675 & 2.053 & 19 & 20 & .059 \\
\hline & & $\begin{array}{l}\text { Average } \\
\text { Measures }\end{array}$ & .513 & -.209 & .806 & 2.053 & 19 & 20 & .059 \\
\hline
\end{tabular}

One-way random effects model where people effects are random.

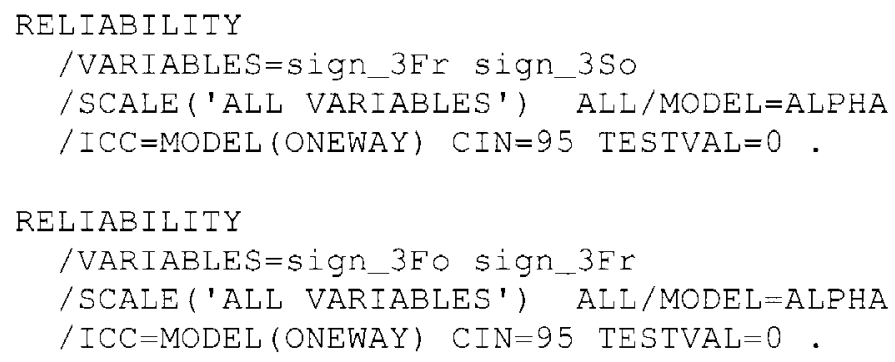

\section{Reliability--FARMAN--SIGN 3}

\section{Notes}

[DataSet 1]

\section{Scale: ALL VARIABLES}

\section{Case Processing Summary}




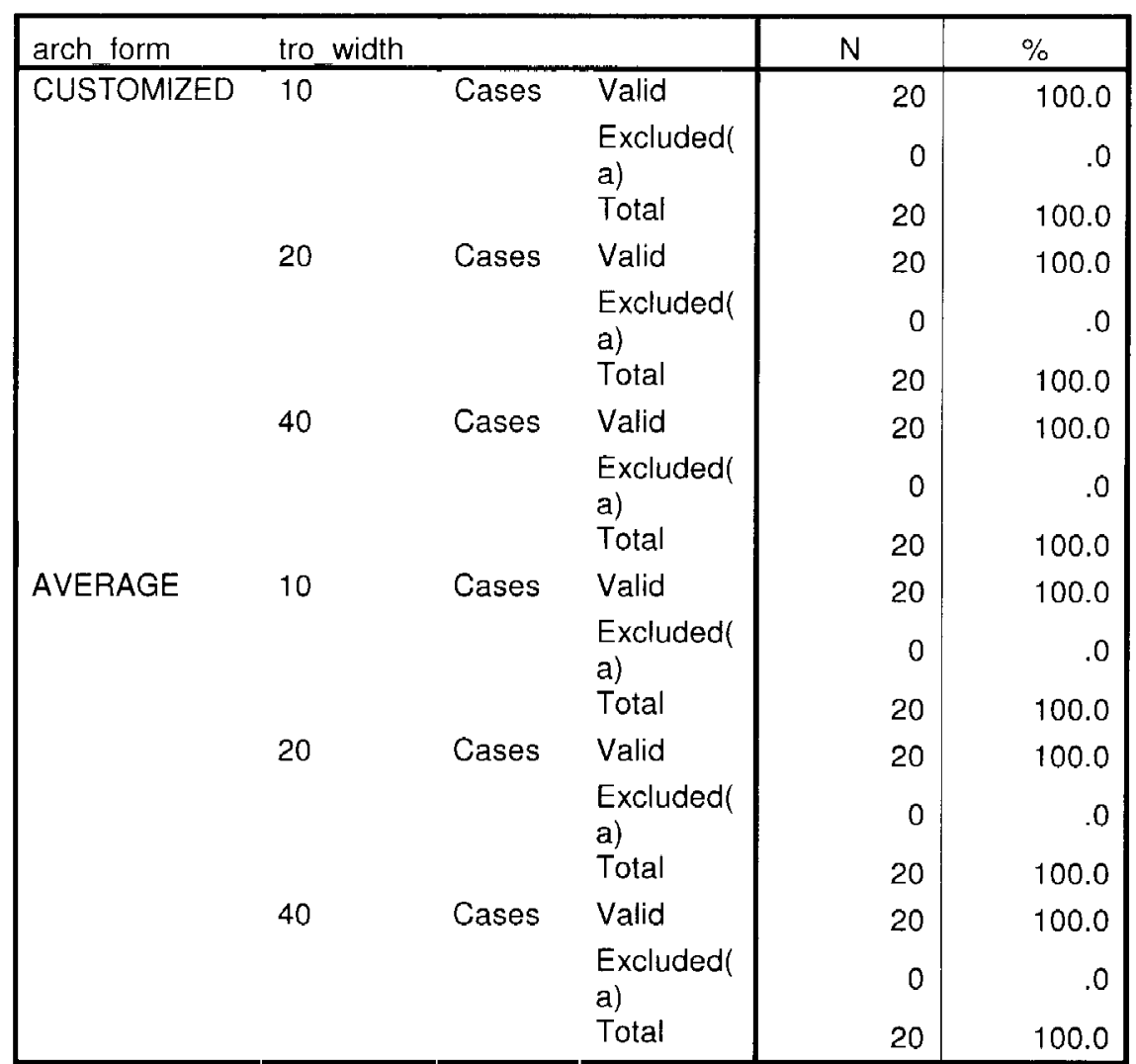

a Listwise deletion based on all variables in the procedure.

\section{Reliability Statistics}

\begin{tabular}{|ll|r|r|}
\hline arch form & tro width & $\begin{array}{c}\text { Cronbach's } \\
\text { Alpha(a) }\end{array}$ & N of Items \\
\hline CUSTOMIZED & 10 & -.250 & 2 \\
& 20 & .472 & 2 \\
& 40 & .704 & 2 \\
AVERAGE & 10 & .933 & 2 \\
& 20 & .681 & 2 \\
& 40 & .882 & 2 \\
\hline
\end{tabular}

a The value is negative due to a negative average covariance among items. This violates reliability model assumptions. You may want to check item codings.

Intraclass Correlation Coefficient

\begin{tabular}{|l|c|c|c|}
\hline arch_form tro_width & $\begin{array}{c}\text { Intraclass } \\
\text { Correlation }\end{array}$ & $\begin{array}{c}95 \% \text { Confidence } \\
\text { Interval }\end{array}$ & F Test with True Value 0 \\
\hline
\end{tabular}




\begin{tabular}{|c|c|c|c|c|c|c|c|c|c|}
\hline & & & & $\begin{array}{l}\text { Upper } \\
\text { Bound }\end{array}$ & Value & df1 & $\mathrm{df} 2$ & Sig & $\begin{array}{l}\text { Lower } \\
\text { Bound }\end{array}$ \\
\hline \multirow[t]{6}{*}{ CUSTOMIZED } & \multirow[t]{2}{*}{10} & $\begin{array}{l}\text { Single } \\
\text { Measures }\end{array}$ & -.086 & -.493 & .357 & .842 & 19 & 20 & .644 \\
\hline & & $\begin{array}{l}\text { Average } \\
\text { Measures }\end{array}$ & -.188 & -1.947 & .527 & .842 & 19 & 20 & .644 \\
\hline & 20 & $\begin{array}{l}\text { Single } \\
\text { Measures }\end{array}$ & .309 & -.134 & .652 & 1.895 & 19 & 20 & .082 \\
\hline & & $\begin{array}{l}\text { Average } \\
\text { Measures }\end{array}$ & .472 & -.310 & .790 & 1.895 & 19 & 20 & .082 \\
\hline & 40 & $\begin{array}{l}\text { Single } \\
\text { Measures }\end{array}$ & .559 & .175 & .797 & 3.536 & 19 & 20 & .004 \\
\hline & & $\begin{array}{l}\text { Average } \\
\text { Measures }\end{array}$ & .717 & .298 & .887 & 3.536 & 19 & 20 & .004 \\
\hline AVERAGE & 10 & $\begin{array}{l}\text { Single } \\
\text { Measures }\end{array}$ & .869 & .704 & .946 & 14.263 & 19 & 20 & .000 \\
\hline & & $\begin{array}{l}\text { Average } \\
\text { Measures }\end{array}$ & 930 & .826 & .972 & 14.263 & 19 & 20 & .000 \\
\hline & 20 & $\begin{array}{l}\text { Single } \\
\text { Measures }\end{array}$ & .533 & .139 & .783 & 3.283 & 19 & 20 & .006 \\
\hline & & $\begin{array}{l}\text { Average } \\
\text { Measures }\end{array}$ & .695 & .244 & .879 & 3.283 & 19 & 20 & .006 \\
\hline & 40 & $\begin{array}{l}\text { Single } \\
\text { Measures }\end{array}$ & .778 & .526 & .905 & 8.000 & 19 & 20 & .000 \\
\hline & & $\begin{array}{l}\text { Average } \\
\text { Measures }\end{array}$ & .875 & .690 & .950 & 8.000 & 19 & 20 & .000 \\
\hline
\end{tabular}

One-way random effects model where people effects are random.

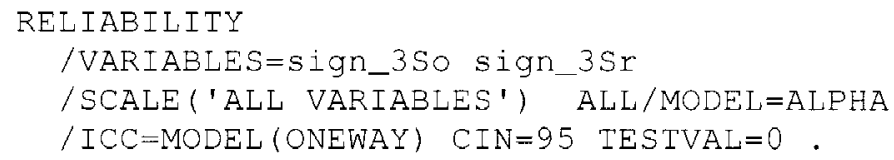

\section{Reliability--CHANDIRMANI--SIGN 3}

\section{Notes}

[Dataset 1]

Scale: ALL VARIABLES

Case Processing Summary

\begin{tabular}{|c|c|c|c|c|c|}
\hline \multirow{3}{*}{$\frac{\text { arch form }}{\text { CUSTOMIZED }}$} & \multicolumn{3}{|c|}{ tro width } & $N$ & $\%$ \\
\hline & 10 & Cases & Valid & 20 & 100.0 \\
\hline & & & $\begin{array}{l}\text { Excluded( } \\
\text { a) } \\
\text { Total }\end{array}$ & $\begin{array}{r}0 \\
20\end{array}$ & $\begin{array}{r}.0 \\
100.0\end{array}$ \\
\hline
\end{tabular}




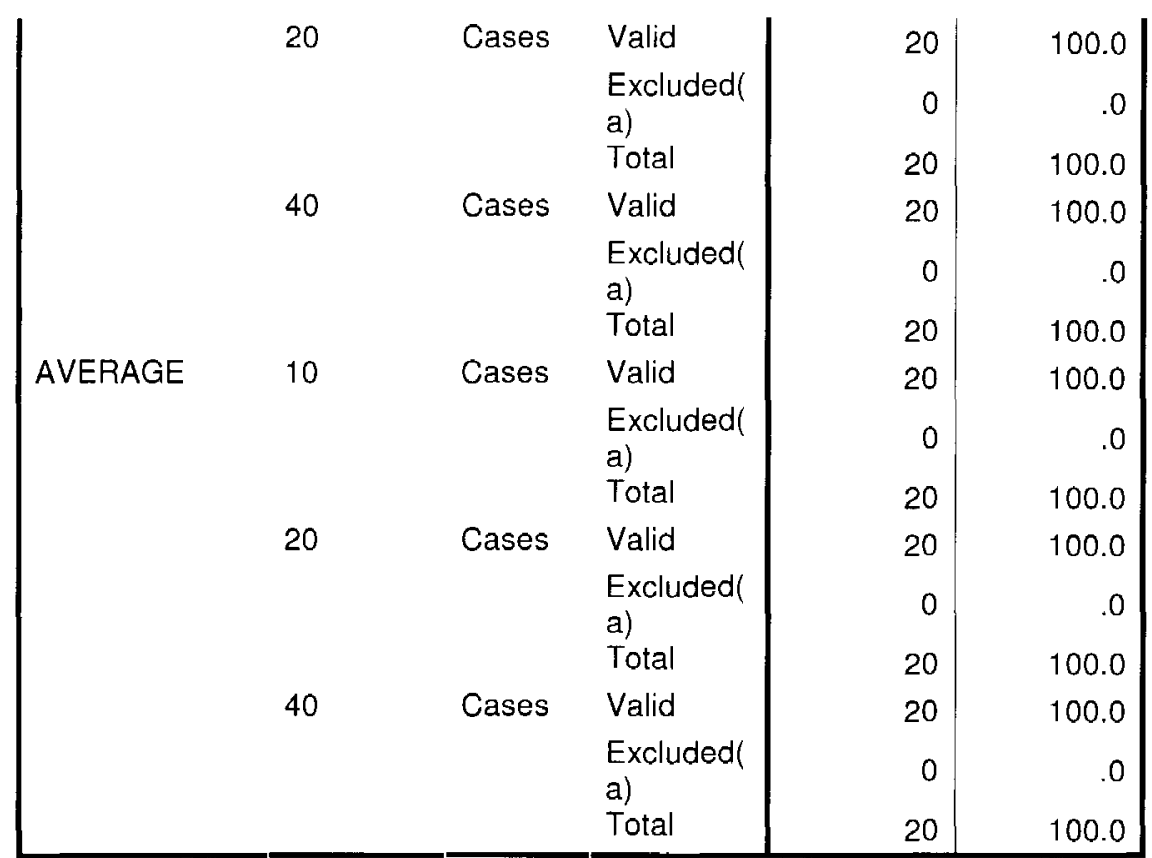

a Listwise deletion based on all variables in the procedure.

Reliability Statistics

\begin{tabular}{|ll|r|r|}
\hline arch form & tro width & $\begin{array}{c}\text { Cronbach's } \\
\text { Alpha(a) }\end{array}$ & N of Items \\
\hline CUSTOMIZED & 10 & .447 & 2 \\
& 20 & -.111 & 2 \\
& 40 & -.209 & 2 \\
AVERAGE & 10 & .986 & 2 \\
& 20 & .804 & 2 \\
& 40 & .286 & 2 \\
\hline
\end{tabular}

a The value is negative due to a negative average covariance among items. This violates reliability model assumptions. You may want to check item codings.

Intraclass Correlation Coefficient

\begin{tabular}{|c|c|c|c|c|c|c|c|c|c|}
\hline \multirow[b]{2}{*}{ arch_form } & \multirow[b]{2}{*}{ tro_width } & & \multirow[b]{2}{*}{$\begin{array}{l}\text { Intraclass } \\
\text { Correlation }\end{array}$} & \multicolumn{2}{|c|}{$\begin{array}{c}95 \% \text { Confidence } \\
\text { Interval }\end{array}$} & \multicolumn{4}{|c|}{ F Test with True Value 0} \\
\hline & & & & $\begin{array}{l}\text { Upper } \\
\text { Bound }\end{array}$ & Value & $d f 1$ & $\mathrm{df} 2$ & $\mathrm{Sig}$ & $\begin{array}{l}\text { Lower } \\
\text { Bound }\end{array}$ \\
\hline \multirow[t]{3}{*}{ CUSTOMIZED } & 10 & $\begin{array}{l}\text { Single } \\
\text { Measures }\end{array}$ & .307 & -.137 & .651 & 1.884 & 19 & 20 & .084 \\
\hline & & $\begin{array}{l}\text { Average } \\
\text { Measures }\end{array}$ & .469 & -.317 & .788 & 1.884 & 19 & 20 & .084 \\
\hline & 20 & $\begin{array}{l}\text { Single } \\
\text { Measures }\end{array}$ & -.027 & -.448 & .408 & .947 & 19 & 20 & .545 \\
\hline
\end{tabular}




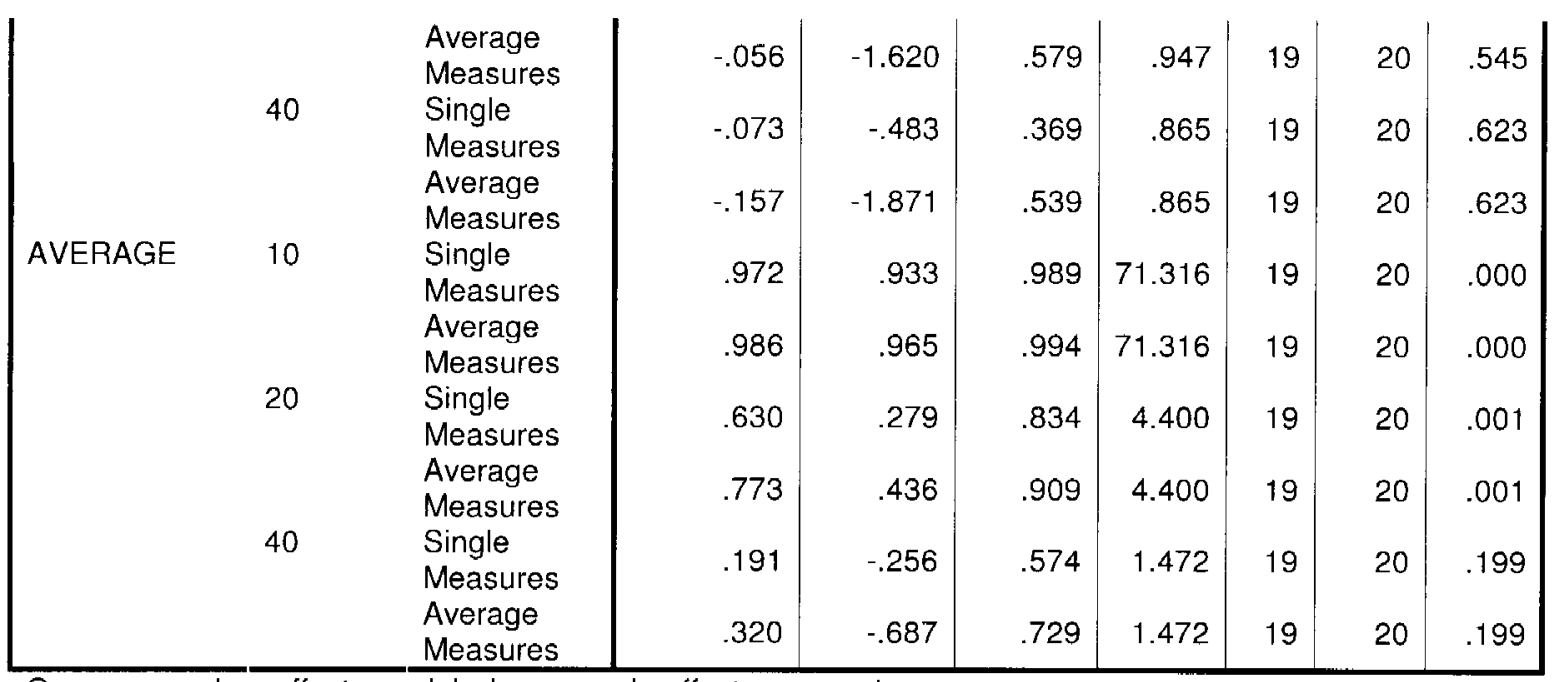

One-way random effects model where people effects are random.

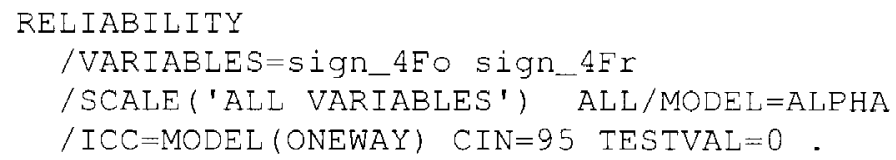

\section{Reliability--FARMAN--SIGN 4}

\section{Notes}

[Dataset 1$]$

\section{Warnings}

For split file arch form=CUSTOMIZED,tro width=20, scale has zero variance items .

\section{Scale: ALL VARIABLES}

Case Processing Summary

\begin{tabular}{|llll|r|r|}
\hline arch form & tro width & & $\mathrm{N}$ & \multicolumn{1}{c|}{$\%$} \\
\hline CUSTOMIZED & 10 & Cases & Valid & 20 & 100.0 \\
& & & Excluded & 0 & .0 \\
& & a) & 20 & 100.0 \\
& & Total & 20 & 100.0 \\
& \multirow{2}{*}{20} & Cases & Valid & 0 & .0
\end{tabular}




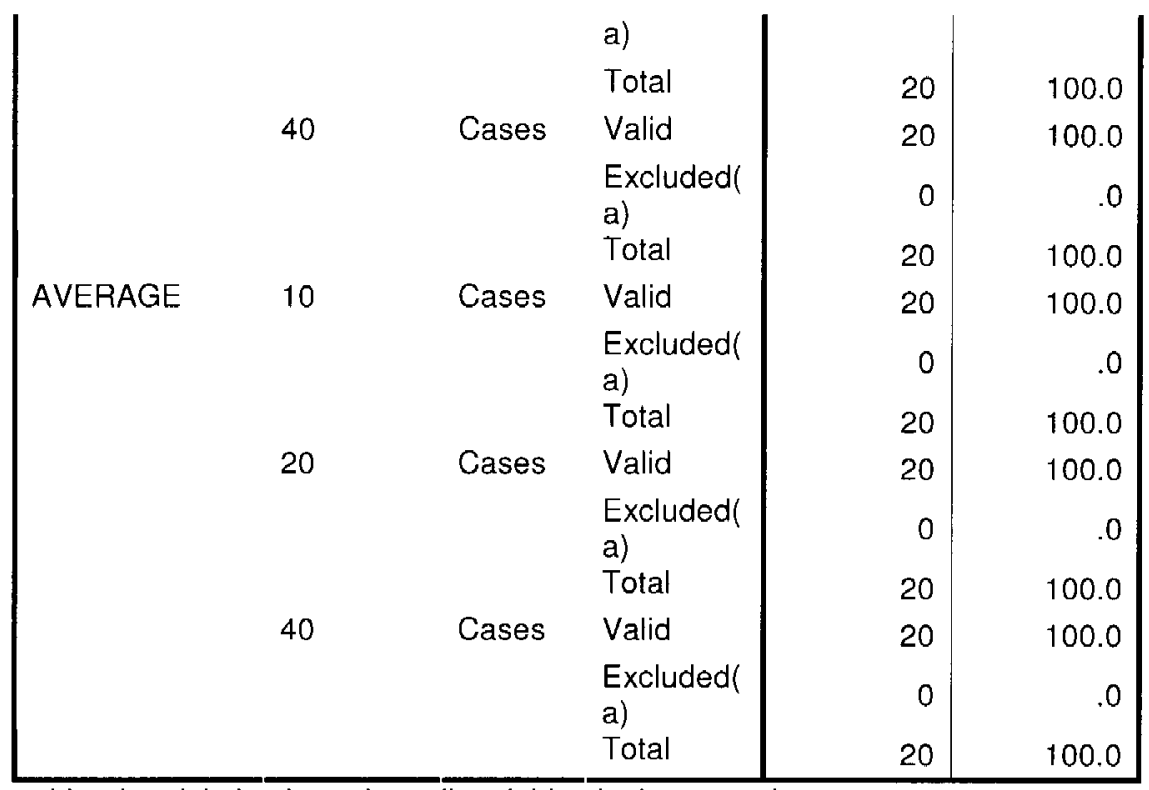

a Listwise deletion based on all variables in the procedure.

Reliability Statistics

\begin{tabular}{|ll|r|r|}
\hline arch_form & tro_width & $\begin{array}{c}\text { Cronbach's } \\
\text { Alpha }\end{array}$ & N of Items \\
\hline CUSTOMIZED & 10 & .000 & 2 \\
& 20 & .000 & 2 \\
& 40 & .655 & 2 \\
AVERAGE & 10 & .950 & 2 \\
& 20 & .698 & 2 \\
& 40 & .732 & 2 \\
\hline
\end{tabular}

Intraclass Correlation Coefficient

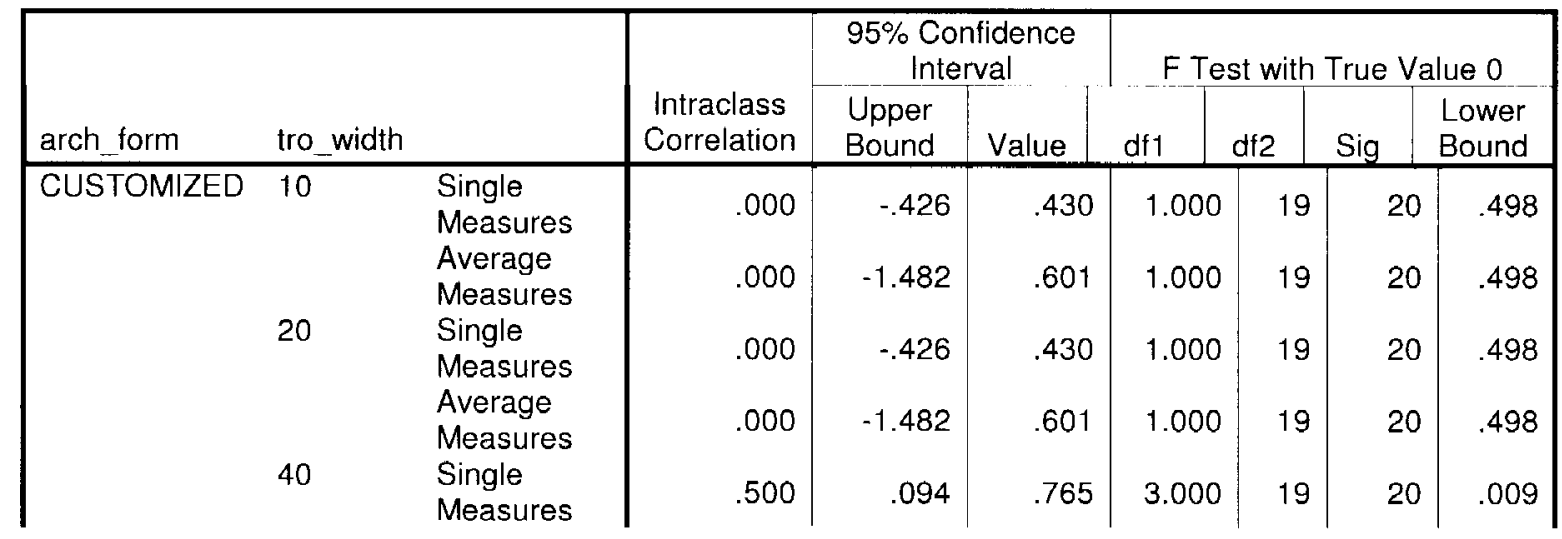




\begin{tabular}{|c|c|c|c|c|c|c|c|c|c|}
\hline \multirow{7}{*}{ AVERAGE } & \multirow[b]{2}{*}{10} & \multirow{2}{*}{$\begin{array}{l}\text { Average } \\
\text { Measures } \\
\text { Single } \\
\text { Measures }\end{array}$} & .667 & .173 & .867 & 3.000 & 19 & 20 & .009 \\
\hline & & & .905 & .779 & .961 & 19.947 & 19 & 20 & .000 \\
\hline & & $\begin{array}{l}\text { Average } \\
\text { Measures }\end{array}$ & .950 & .876 & .980 & & 19 & 20 & .000 \\
\hline & 20 & $\begin{array}{l}\text { Single } \\
\text { Measures }\end{array}$ & .553 & .167 & .794 & 3.478 & 19 & 20 & .004 \\
\hline & & $\begin{array}{l}\text { Average } \\
\text { Measures }\end{array}$ & .712 & .286 & .885 & 3.478 & 19 & 20 & .004 \\
\hline & 40 & $\begin{array}{l}\text { Single } \\
\text { Measures }\end{array}$ & .578 & .202 & .807 & 3.737 & 19 & 20 & .003 \\
\hline & & $\begin{array}{l}\text { Average } \\
\text { Measures }\end{array}$ & .732 & .336 & .893 & 3.737 & 19 & 20 & .003 \\
\hline
\end{tabular}

One-way random effects model where people effects are random.

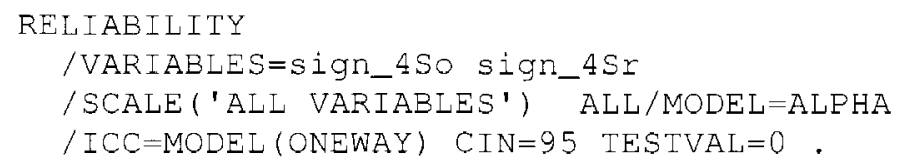

\section{Reliability--CHANDIRMANI--SIGN 4}

Notes

[Dataset 1]

\section{Scale: ALL VARIABLES}

Case Processing Summary

\begin{tabular}{|c|c|c|c|c|c|}
\hline arch form & tro width & & & $\mathrm{N}$ & $\%$ \\
\hline \multirow[t]{9}{*}{ CUSTOMIZED } & 10 & Cases & Valid & 20 & 100.0 \\
\hline & & & $\begin{array}{l}\text { Excluded( } \\
\text { a) }\end{array}$ & 0 & .0 \\
\hline & & & Total & 20 & 100.0 \\
\hline & 20 & Cases & Valid & 20 & 100.0 \\
\hline & & & $\begin{array}{l}\text { Excluded( } \\
\text { a) }\end{array}$ & 0 & .0 \\
\hline & & & Total & 20 & 100.0 \\
\hline & 40 & Cases & Valid & 20 & 100.0 \\
\hline & & & $\begin{array}{l}\text { Excluded( } \\
\text { a) }\end{array}$ & 0 & .0 \\
\hline & & & Total & 20 & 100.0 \\
\hline \multirow[t]{2}{*}{ AVERAGE } & 10 & Cases & Valid & 20 & 100.0 \\
\hline & & & Excluded( & 0 &. \\
\hline
\end{tabular}




\begin{tabular}{|c|c|c|c|c|}
\hline \multirow[b]{3}{*}{20} & \multirow[b]{3}{*}{ Cases } & a) & \multirow[b]{2}{*}{20} & \multirow{3}{*}{$\begin{array}{r}100.0 \\
100.0\end{array}$} \\
\hline & & Total & & \\
\hline & & Valid & 20 & \\
\hline & & $\begin{array}{l}\text { Excluded( } \\
\text { a) }\end{array}$ & 0 & .0 \\
\hline & & Total & 20 & 100.0 \\
\hline 40 & Cases & Valid & 20 & 100.0 \\
\hline & & $\begin{array}{l}\text { Excluded( } \\
\text { a) }\end{array}$ & 0 & \\
\hline & & Total & 20 & 100.0 \\
\hline
\end{tabular}

a Listwise deletion based on all variables in the procedure.

\section{Reliability Statistics}

\begin{tabular}{|ll|r|r|}
\hline arch_form & tro_width & $\begin{array}{c}\text { Cronbach's } \\
\text { Alpha }\end{array}$ & N of Items \\
\hline CUSTOMIZED & 10 & .478 & 2 \\
& 20 & .356 & 2 \\
& 40 & .051 & 2 \\
AVERAGE & 10 & .985 & 2 \\
& 20 & .795 & 2 \\
& 40 & .227 & 2 \\
\hline
\end{tabular}

Intraclass Correlation Coefficient

\begin{tabular}{|c|c|c|c|c|c|c|c|c|c|}
\hline \multirow[b]{2}{*}{ arch_form } & \multirow[b]{2}{*}{ tro_width } & & \multirow[b]{2}{*}{$\begin{array}{l}\text { Intraclass } \\
\text { Correlation }\end{array}$} & \multicolumn{2}{|c|}{$\begin{array}{c}95 \% \text { Confidence } \\
\text { Interval }\end{array}$} & \multicolumn{4}{|c|}{ F Test with True Value 0} \\
\hline & & & & $\begin{array}{l}\text { Upper } \\
\text { Bound }\end{array}$ & Value & $\mathrm{df} 1$ & $\mathrm{df} 2$ & Sig & $\begin{array}{l}\text { Lower } \\
\text { Bound }\end{array}$ \\
\hline \multirow[t]{6}{*}{ CUSTOMIZED } & 10 & $\begin{array}{l}\text { Single } \\
\text { Measures }\end{array}$ & .307 & -.136 & .651 & 1.887 & 19 & 20 & .084 \\
\hline & & $\begin{array}{l}\text { Average } \\
\text { Measures }\end{array}$ & .470 & .315 & .789 & 1.887 & 19 & 20 & .084 \\
\hline & 20 & $\begin{array}{l}\text { Single } \\
\text { Measures }\end{array}$ & .224 & -.222 & .597 & 1.579 & 19 & 20 & .159 \\
\hline & & $\begin{array}{l}\text { Average } \\
\text { Measures }\end{array}$ & .367 & -.572 & .748 & 1.579 & 19 & 20 & .159 \\
\hline & 40 & $\begin{array}{l}\text { Single } \\
\text { Measures }\end{array}$ & .017 & -.411 & .444 & 1.035 & 19 & 20 & .468 \\
\hline & & $\begin{array}{l}\text { Average } \\
\text { Measures }\end{array}$ & .034 & -1.398 & .615 & 1.035 & 19 & 20 & .468 \\
\hline \multirow[t]{4}{*}{ AVERAGE } & 10 & $\begin{array}{l}\text { Single } \\
\text { Measures }\end{array}$ & .970 & .927 & .988 & 65.842 & 19 & 20 & .000 \\
\hline & & $\begin{array}{l}\text { Average } \\
\text { Measures }\end{array}$ & .985 & .962 & .994 & 65.842 & 19 & 20 & .000 \\
\hline & 20 & $\begin{array}{l}\text { Single } \\
\text { Measures }\end{array}$ & .660 & .326 & .849 & 4.883 & 19 & 20 & .000 \\
\hline & & & .795 & .492 & .918 & 4.883 & 19 & 20 & .000 \\
\hline
\end{tabular}




\begin{tabular}{|l|l|r|r|r|r|r|r|r|}
\hline 40 & $\begin{array}{l}\text { Measures } \\
\text { Single } \\
\text { Measures } \\
\text { Average } \\
\text { Measures }\end{array}$ & .149 & -.296 & .544 & 1.349 & 19 & 20 & .256 \\
& .259 & -.840 & .705 & 1.349 & 19 & 20 & .256 \\
\hline
\end{tabular}

One-way random effects model where people effects are random.

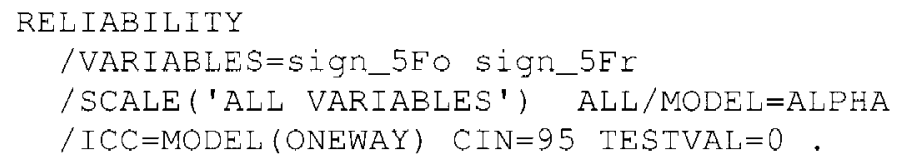

\section{Reliability--FARMAN--SIGN 5}

\section{Notes}

[ Dataset 1]

Scale: ALL VARIABLES

Case Processing Summary

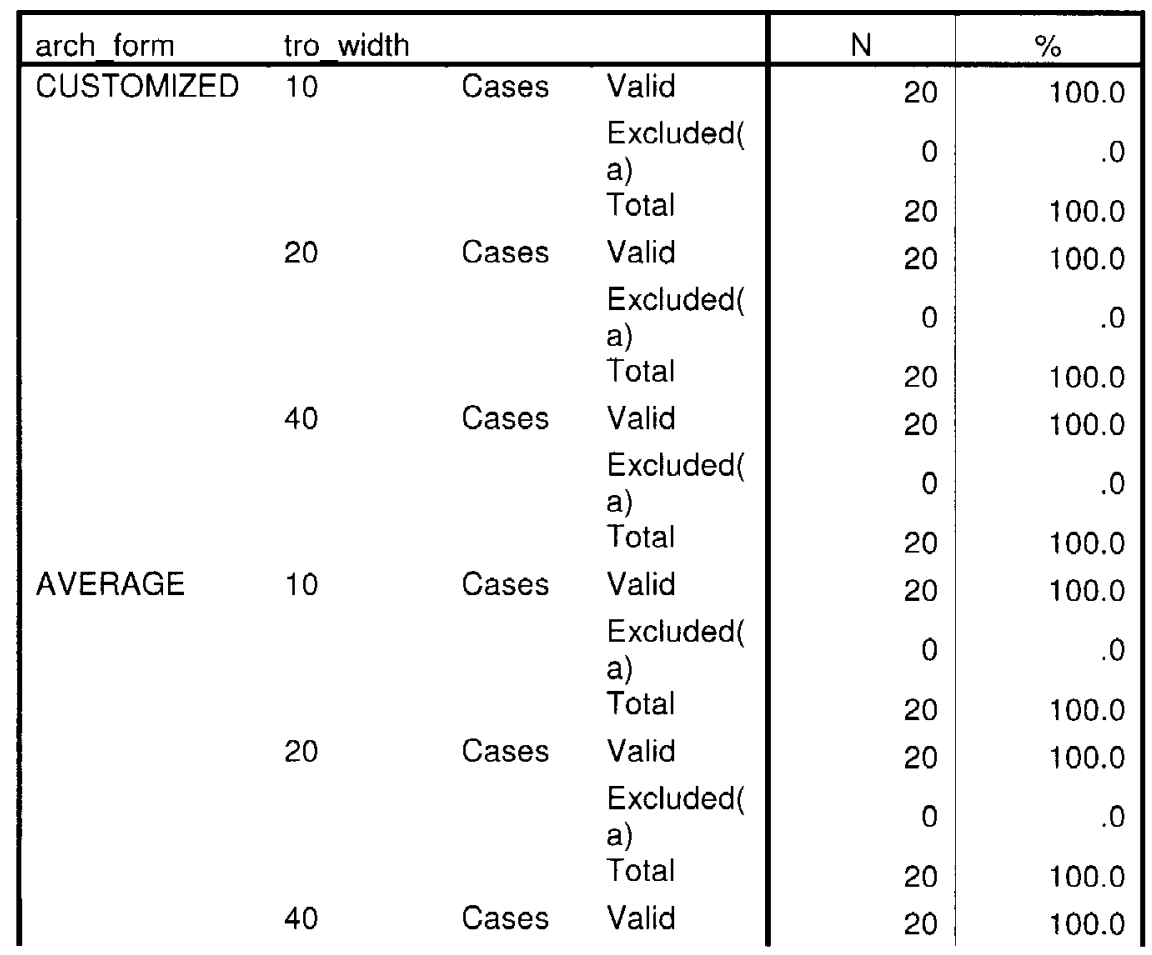




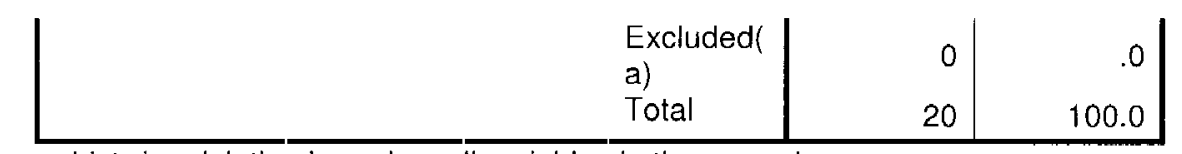

a Listwise deletion based on all variables in the procedure.

\section{Reliability Statistics}

\begin{tabular}{|ll|r|r|}
\hline arch form & tro width & $\begin{array}{c}\text { Cronbach's } \\
\text { Alpha }\end{array}$ & N of Items \\
\hline CUSTOMIZED & 10 & .749 & 2 \\
& 20 & .385 & 2 \\
& 40 & .371 & 2 \\
AVERAGE & 10 & .931 & 2 \\
& 20 & .831 & 2 \\
& 40 & .645 & 2 \\
\hline
\end{tabular}

Intraclass Correlation Coefficient

\begin{tabular}{|c|c|c|c|c|c|c|c|c|c|}
\hline \multirow[b]{2}{*}{ arch_form } & \multirow[b]{2}{*}{ tro width } & & \multirow[b]{2}{*}{$\begin{array}{l}\text { Intraclass } \\
\text { Correlation }\end{array}$} & \multicolumn{2}{|c|}{$\begin{array}{c}95 \% \text { Confidence } \\
\text { Interval }\end{array}$} & \multicolumn{4}{|c|}{ F Test with True Value 0} \\
\hline & & & & $\begin{array}{l}\text { Upper } \\
\text { Bound }\end{array}$ & Value & df 1 & $\mathrm{df2}$ & Sig & $\begin{array}{l}\text { Lower } \\
\text { Bound }\end{array}$ \\
\hline \multirow[t]{6}{*}{ CUSTOMIZED } & 10 & $\begin{array}{l}\text { Single } \\
\text { Measures }\end{array}$ & .518 & .118 & .775 & 3.147 & 19 & 20 & .007 \\
\hline & & $\begin{array}{l}\text { Average } \\
\text { Measures }\end{array}$ & 682 & .211 & .873 & 3.147 & 19 & 20 & .007 \\
\hline & 20 & $\begin{array}{l}\text { Single } \\
\text { Measures }\end{array}$ & .260 & -.187 & .620 & 1.702 & 19 & 20 & .123 \\
\hline & & $\begin{array}{l}\text { Average } \\
\text { Measures }\end{array}$ & .412 & -.459 & .766 & 1.702 & 19 & 20 & .123 \\
\hline & 40 & $\begin{array}{l}\text { Single } \\
\text { Measures }\end{array}$ & .251 & -.196 & .614 & 1.669 & 19 & 20 & .132 \\
\hline & & $\begin{array}{l}\text { Average } \\
\text { Measures }\end{array}$ & .401 & -.487 & .761 & 1.669 & 19 & 20 & .132 \\
\hline \multirow[t]{6}{*}{ AVERAGE } & 10 & $\begin{array}{l}\text { Single } \\
\text { Measures }\end{array}$ & 871 & .707 & .946 & 14.474 & 19 & 20 & .000 \\
\hline & & $\begin{array}{l}\text { Average } \\
\text { Measures }\end{array}$ & .931 & .829 & .972 & 14.474 & 19 & 20 & .000 \\
\hline & 20 & $\begin{array}{l}\text { Single } \\
\text { Measures }\end{array}$ & .717 & .420 & 877 & 6.079 & 19 & 20 & .000 \\
\hline & & $\begin{array}{l}\text { Average } \\
\text { Measures }\end{array}$ & .835 & .592 & .934 & 6.079 & 19 & 20 & .000 \\
\hline & 40 & $\begin{array}{l}\text { Single } \\
\text { Measures }\end{array}$ & .434 & .011 & .728 & 2.536 & 19 & 20 & .023 \\
\hline & & $\begin{array}{l}\text { Average } \\
\text { Measures }\end{array}$ & .606 & .021 & .843 & 2.536 & 19 & 20 & .023 \\
\hline
\end{tabular}

One-way random effects model where people effects are random. 


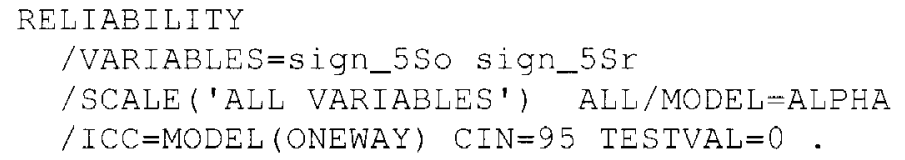

\section{Reliability--CHANDIRMANI--SIGN 5}

\section{Notes}

[Dataset 1]

\section{Warnings}

For split file arch_form=CUSTOMIZED,tro_width=20, scale has zero variance items.

\section{Scale: ALL VARIABLES}

Case Processing Summary

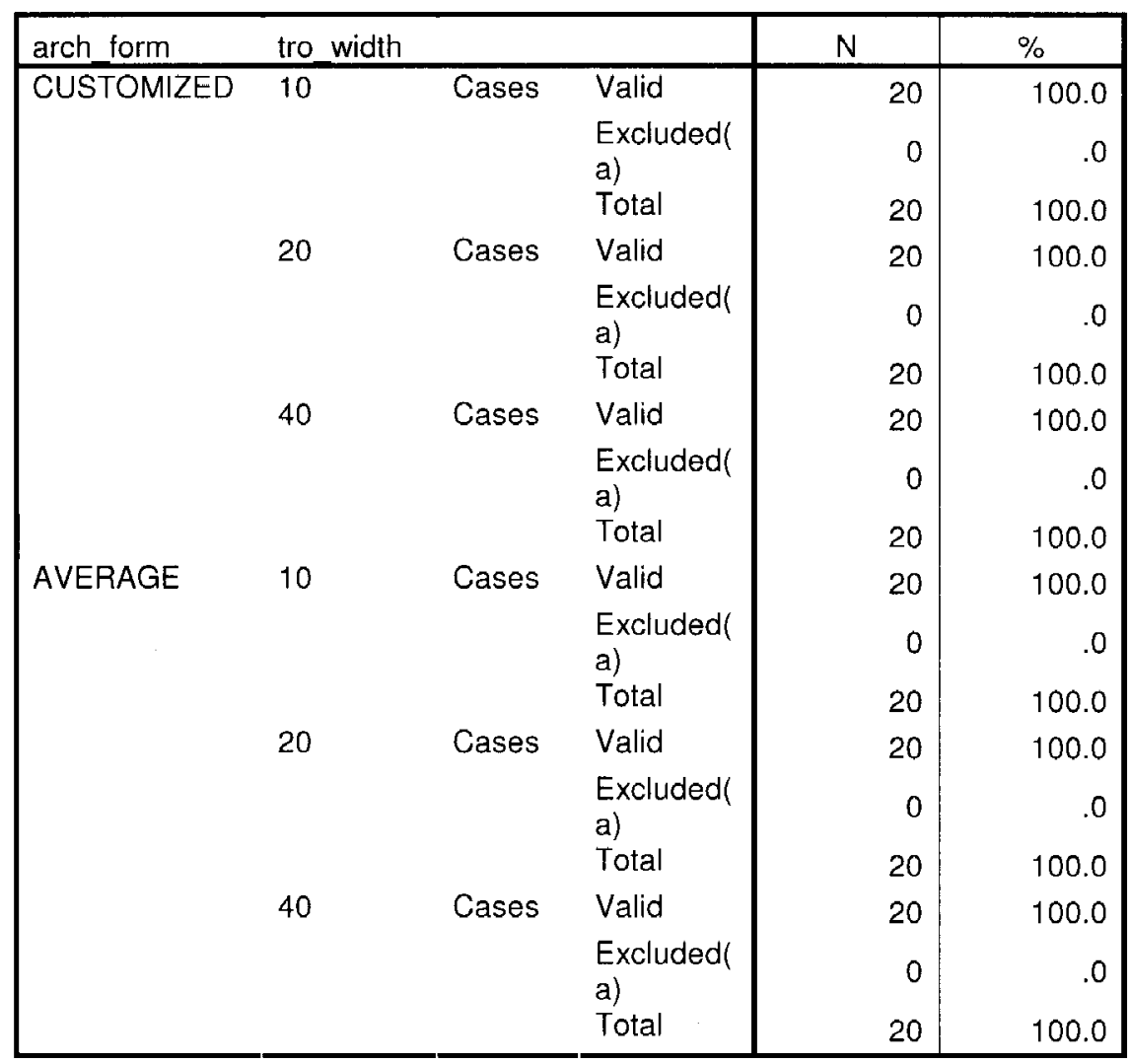


a Listwise deletion based on all variables in the procedure.

Reliability Statistics

\begin{tabular}{|ll|r|r|}
\hline arch_form & tro_width & \multicolumn{1}{c|}{$\begin{array}{c}\text { Cronbach's } \\
\text { Alpha }\end{array}$} & N of Items \\
\hline CUSTOMIZED & 10 & .382 & 2 \\
& 20 & $4.39 E-016$ & 2 \\
& 40 & .148 & 2 \\
AVERAGE & 10 & .908 & 2 \\
& 20 & .687 & 2 \\
& 40 & .264 & 2 \\
\hline
\end{tabular}

Intraclass Correlation Coefficient

\begin{tabular}{|c|c|c|c|c|c|c|c|c|c|}
\hline \multirow[b]{2}{*}{ arch_form } & \multirow[b]{2}{*}{ tro_width } & & \multirow[b]{2}{*}{$\begin{array}{l}\text { Intraclass } \\
\text { Correlation }\end{array}$} & \multicolumn{2}{|c|}{$\begin{array}{c}95 \% \text { Confidence } \\
\text { Interval }\end{array}$} & \multicolumn{4}{|c|}{ F Test with True Value 0} \\
\hline & & & & $\begin{array}{l}\text { Upper } \\
\text { Bound }\end{array}$ & Value & $\mathrm{df1}$ & $\mathrm{df} 2$ & Sig & $\begin{array}{l}\text { Lower } \\
\text { Bound }\end{array}$ \\
\hline \multirow[t]{6}{*}{ CUSTOMIZED } & 10 & $\begin{array}{l}\text { Single } \\
\text { Measures }\end{array}$ & .088 & -.351 & .499 & 1.193 & 19 & 20 & .349 \\
\hline & & $\begin{array}{l}\text { Average } \\
\text { Measures }\end{array}$ & .162 & -1.081 & .666 & 1.193 & 19 & 20 & .349 \\
\hline & 20 & $\begin{array}{l}\text { Single } \\
\text { Measures }\end{array}$ & -.226 & -.594 & .226 & .632 & 19 & 20 & .839 \\
\hline & & $\begin{array}{l}\text { Average } \\
\text { Measures }\end{array}$ & -.583 & -2.930 & .369 & .632 & 19 & 20 & .839 \\
\hline & 40 & $\begin{array}{l}\text { Single } \\
\text { Measures }\end{array}$ & .064 & -.372 & .481 & 1.137 & 19 & 20 & .388 \\
\hline & & $\begin{array}{l}\text { Average } \\
\text { Measures }\end{array}$ & .120 & -1.183 & .649 & 1.137 & 19 & 20 & .388 \\
\hline \multirow[t]{6}{*}{ AVERAGE } & 10 & $\begin{array}{l}\text { Single } \\
\text { Measures }\end{array}$ & .790 & .549 & .911 & 8.537 & 19 & 20 & .000 \\
\hline & & $\begin{array}{l}\text { Average } \\
\text { Measures }\end{array}$ & .883 & .709 & .953 & 8.537 & 19 & 20 & .000 \\
\hline & 20 & $\begin{array}{l}\text { Single } \\
\text { Measures }\end{array}$ & .539 & .147 & .787 & 3.339 & 19 & 20 & .005 \\
\hline & & $\begin{array}{l}\text { Average } \\
\text { Measures }\end{array}$ & .701 & .257 & .881 & 3.339 & 19 & 20 & .005 \\
\hline & 40 & $\begin{array}{l}\text { Single } \\
\text { Measures }\end{array}$ & .125 & -.317 & .527 & 1.287 & 19 & 20 & .290 \\
\hline & & $\begin{array}{l}\text { Average } \\
\text { Measures }\end{array}$ & .223 & -.929 & .690 & 1.287 & 19 & 20 & .290 \\
\hline
\end{tabular}

One-way random effects model where people effects are random.

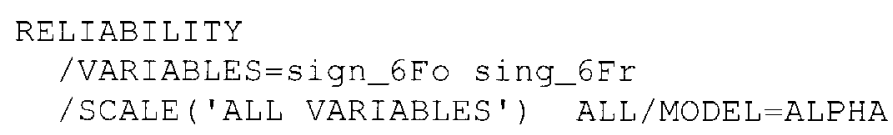


$/$ ICC=MODEL (ONEWAY) $\quad$ CIN=95 TESTVAL $=0$.

\section{Reliability--FARMAN--SIGN 6}

Notes

[Dataset1]

Scale: ALL VARIABLES

Case Processing Summary

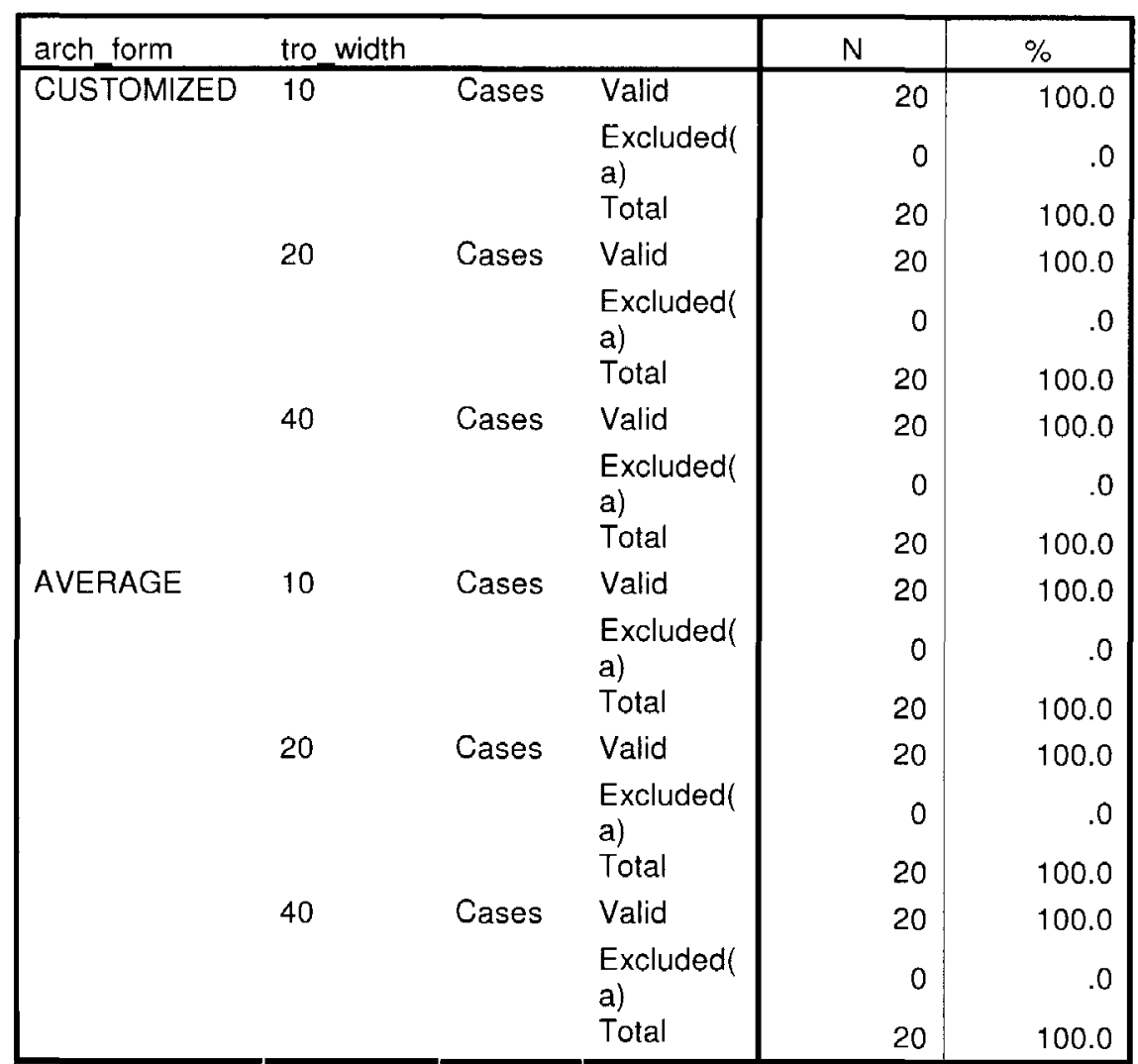

a Listwise deletion based on all variables in the procedure.

\section{Reliability Statistics}

\begin{tabular}{|ll|r|r|}
\hline arch_form & tro_width & $\begin{array}{c}\text { Cronbach's } \\
\text { Alpha }\end{array}$ & N of Items \\
\hline CUSTOMIZED & 10 & .545 & 2
\end{tabular}




\begin{tabular}{|ll|l|l|} 
& 20 & .608 & 2 \\
AVERAGE & 40 & .665 & 2 \\
& 10 & .919 & 2 \\
& 20 & .766 & 2 \\
& 40 & .664 & 2 \\
\hline
\end{tabular}

Intraclass Correlation Coefficient

\begin{tabular}{|c|c|c|c|c|c|c|c|c|c|}
\hline \multirow[b]{2}{*}{ arch_form } & \multirow[b]{2}{*}{ tro_width } & & \multirow[b]{2}{*}{$\begin{array}{l}\text { Intraclass } \\
\text { Correlation }\end{array}$} & \multicolumn{2}{|c|}{$\begin{array}{l}95 \% \text { Confidence } \\
\text { Interval }\end{array}$} & \multicolumn{4}{|c|}{ F Test with True Value 0} \\
\hline & & & & $\begin{array}{l}\text { Upper } \\
\text { Bound }\end{array}$ & Value & df1 & df2 & Sig & $\begin{array}{l}\text { Lower } \\
\text { Bound }\end{array}$ \\
\hline \multirow[t]{6}{*}{ CUSTOMIZED } & 10 & $\begin{array}{l}\text { Single } \\
\text { Measures }\end{array}$ & .397 & -.035 & .706 & 2.316 & 19 & 20 & .035 \\
\hline & & $\begin{array}{l}\text { Average } \\
\text { Measures }\end{array}$ & .568 & -.072 & .828 & 2.316 & 19 & 20 & .035 \\
\hline & 20 & $\begin{array}{l}\text { Single } \\
\text { Measures }\end{array}$ & 444 & .023 & .734 & 2.596 & 19 & 20 & .020 \\
\hline & & $\begin{array}{l}\text { Average } \\
\text { Measures }\end{array}$ & .615 & .044 & .846 & 2.596 & 19 & 20 & .020 \\
\hline & 40 & $\begin{array}{l}\text { Single } \\
\text { Measures }\end{array}$ & .511 & .109 & .771 & 3.088 & 19 & 20 & .008 \\
\hline & & $\begin{array}{l}\text { Average } \\
\text { Measures }\end{array}$ & 676 & .196 & .871 & 3.088 & 19 & 20 & .008 \\
\hline \multirow[t]{6}{*}{ AVERAGE } & 10 & $\begin{array}{l}\text { Single } \\
\text { Measures }\end{array}$ & .837 & 639 & .932 & 11.263 & 19 & 20 & .000 \\
\hline & & $\begin{array}{l}\text { Average } \\
\text { Measures }\end{array}$ & .911 & .780 & .965 & 11.263 & 19 & 20 & .000 \\
\hline & 20 & $\begin{array}{l}\text { Single } \\
\text { Measures }\end{array}$ & 637 & .290 & .837 & 4.505 & 19 & 20 & .001 \\
\hline & & $\begin{array}{l}\text { Average } \\
\text { Measures }\end{array}$ & .778 & .449 & .912 & 4.505 & 19 & 20 & .001 \\
\hline & 40 & $\begin{array}{l}\text { Single } \\
\text { Measures }\end{array}$ & .476 & .064 & .752 & 2.819 & 19 & 20 & .013 \\
\hline & & $\begin{array}{l}\text { Average } \\
\text { Measures }\end{array}$ & 645 & .119 & .859 & 2.819 & 19 & 20 & .013 \\
\hline
\end{tabular}

One-way random effects model where people effects are random.

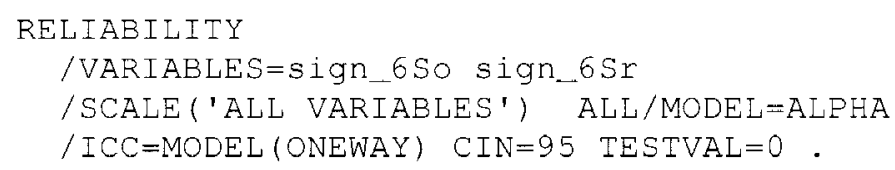

\section{Reliability--CHANDIRMANI--SIGN 6}

\section{Notes}


[Dataset 1]

\section{Scale: ALL VARIABLES}

\section{Case Processing Summary}

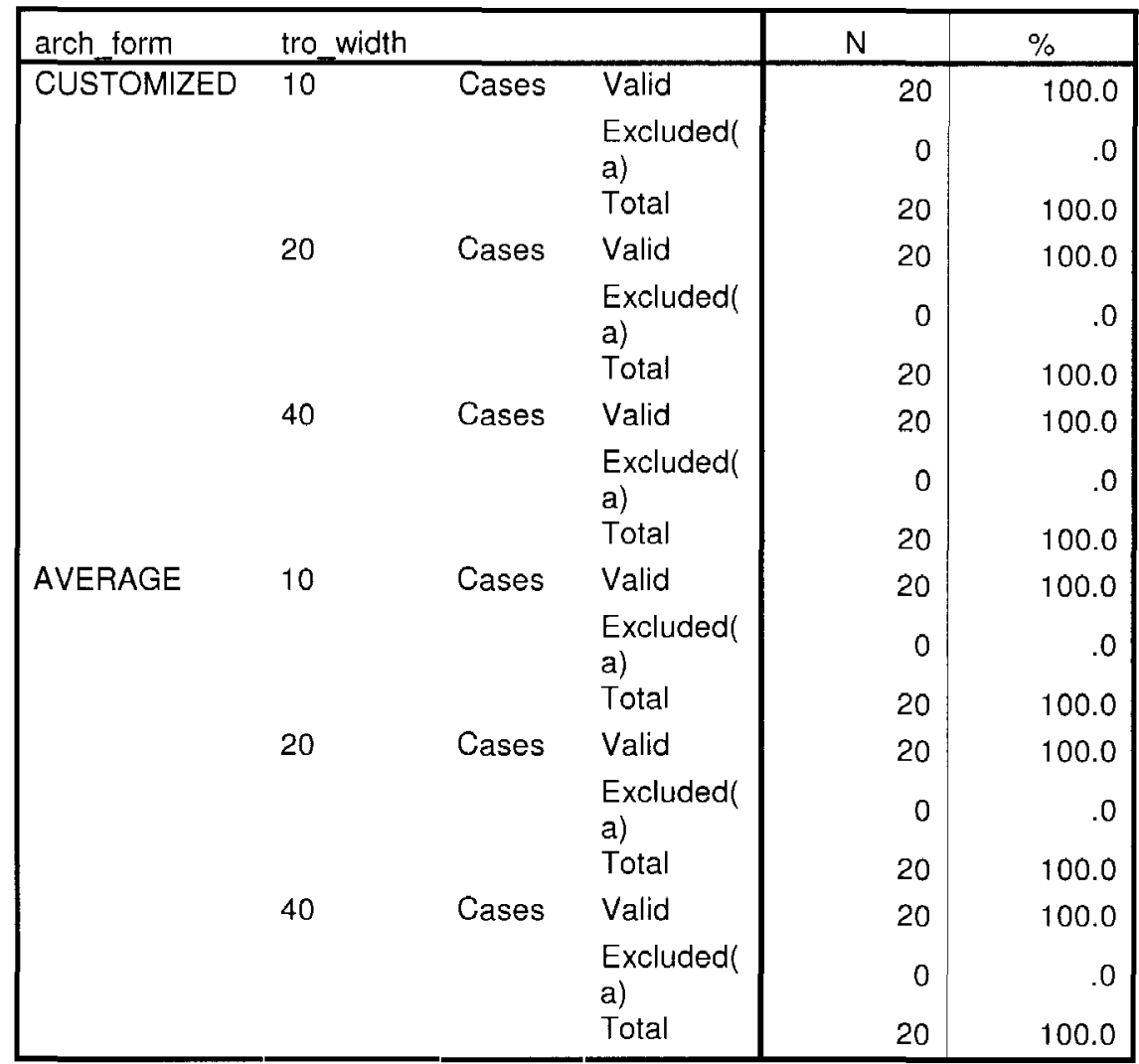

a Listwise deletion based on all variables in the procedure.

\section{Reliability Statistics}

\begin{tabular}{|ll|r|r|}
\hline arch form & tro width & $\begin{array}{c}\text { Cronbach's } \\
\text { Alpha(a) }\end{array}$ & N of Items \\
\hline CUSTOMIZED & 10 & .447 & 2 \\
& 20 & -.320 & 2 \\
AVERAGE & 10 & .234 & 2 \\
& 20 & .950 & 2 \\
& 40 & .799 & 2 \\
& 10 & .333 & 2 \\
\hline
\end{tabular}

a The value is negative due to a negative average covariance among items. This violates reliability model assumptions. You may want to check item codings. 


\section{Intraclass Correlation Coefficient}

\begin{tabular}{|c|c|c|c|c|c|c|c|c|c|}
\hline \multirow[b]{2}{*}{ arch_form } & \multirow[b]{2}{*}{ tro_width } & & \multirow[b]{2}{*}{$\begin{array}{l}\text { Intraclass } \\
\text { Correlation }\end{array}$} & \multicolumn{2}{|c|}{$\begin{array}{l}95 \% \text { Confidence } \\
\text { Interval }\end{array}$} & \multicolumn{4}{|c|}{ F Test with True Value 0} \\
\hline & & & & $\begin{array}{l}\text { Upper } \\
\text { Bound }\end{array}$ & Value & df1 & $\mathrm{df} 2$ & Sig & $\begin{array}{l}\text { Lower } \\
\text { Bound }\end{array}$ \\
\hline \multirow[t]{6}{*}{ CUSTOMIZED } & 10 & Single & .307 & -.137 & .651 & 1.884 & 19 & 20 & .084 \\
\hline & & Average & .469 & -.317 & .788 & 1.884 & 19 & 20 & .084 \\
\hline & 20 & Single & -.118 & -.517 & .329 & .789 & 19 & 20 & .695 \\
\hline & & $\begin{array}{l}\text { Average } \\
\text { Measures }\end{array}$ & -.267 & -2.144 & .495 & .789 & 19 & 20 & .695 \\
\hline & 40 & $\begin{array}{l}\text { Single } \\
\text { Measures }\end{array}$ & .125 & -.318 & .527 & 1.286 & 19 & 20 & .291 \\
\hline & & $\begin{array}{l}\text { Average } \\
\text { Measures }\end{array}$ & .222 & -.931 & & 1.286 & 19 & 20 & .291 \\
\hline \multirow[t]{6}{*}{ AVERAGE } & 10 & $\begin{array}{l}\text { Single } \\
\text { Measures }\end{array}$ & .905 & .779 & .961 & 19.947 & 19 & 20 & .000 \\
\hline & & $\begin{array}{l}\text { Average } \\
\text { Measures }\end{array}$ & .950 & .876 & .980 & 19.947 & 19 & 20 & .000 \\
\hline & 20 & $\begin{array}{l}\text { Single } \\
\text { Measures }\end{array}$ & .665 & .334 & .852 & 4.977 & 19 & 20 & .000 \\
\hline & & $\begin{array}{l}\text { Average } \\
\text { Measures }\end{array}$ & .799 & .501 & .920 & 4.977 & 19 & 20 & .000 \\
\hline & 40 & $\begin{array}{l}\text { Single } \\
\text { Measures }\end{array}$ & .224 & -.222 & .597 & 1.579 & 19 & 20 & .159 \\
\hline & & $\begin{array}{l}\text { Average } \\
\text { Measures }\end{array}$ & .367 & -.572 & .748 & 1.579 & 19 & 20 & .159 \\
\hline
\end{tabular}




\section{CURRICULUM VITAE \\ Ryan L. Snyder, D.M.D., MAJ DC \\ May, 2007}

\section{University of Louisville Orthodontic residency \\ Second year resident \\ ryan.snyder@us.army.mil}

\section{CURRENT}

POSITION

EDUCATION
-Orthodontic resident

University of Louisville Orthodontic residency

-Advanced Education General Dentistry

Residency lyr Program

Ft. Benning, GA

SEP99-SEP00

-University of Pittsburgh School of Dental Medicine Pittsburgh, PA

Doctorate of Dental Medicine

AUG95-JUN99

-University of Pittsburgh at Bradford

Bradford, PA

B.S. Biology, Minor: Chemistry

AUG91-MAY95

-National Board Certified General Dentist

-North East Region Board Certified General Dentist

-Advanced Cardiac Life Support Certified

-Basic Life Support Instructor Certified

-Advanced Trauma Life Support Certified

-Basic Trauma Life Support Certified 
HONORS and AWARDS

-Bronze Star Medal

-Meritorious Service Medal

-National Defense Service Medal

-Global War On Terrorism Expeditionary Medal

-Global War On Terrorism Service Medal

-Army Service Ribbon

-Overseas Service Ribbon

-German Proficiency Badge

-Graduated Cum Laude B.S. Biology 1995

- Member Alpha Lambda Delta-

National Honorary Society for freshman with

GPA 3.5 or higher in first term

RELEVANT

EXPERIENCE
-General Dentist

Company Commander

U.S. Army Dental Corps

DENTAC

Ft. Hood, TX

Provided comprehensive and emergency dental care to the soldiers at DC\#5, Ft. Hood, TX.

In charge of all U.S. Army DENTAC personnel and administrative actions at the Ft. Hood DENTAC.

-General Dentist

Platoon Leader

U.S. Army Dental Corps

$561^{\text {st }}$ MED CO (DS)

Vilseck, Germany

Provided comprehensive and emergency

dental care to the Grafenwoehr and 
Vilseck communities.

OCT00-OCT03

-Deployed to IRAQ and provided

emergency and routine dental care to U.S. and Coalition soldiers.

-General Dentist Resident

AEGD 1yr. program

U.S. Army Dental Corps

DENTAC

Ft. Benning, GA

Provided comprehensive dental care to active duty soldiers on Ft. Benning Army post and completed a 1 yr. AEGD residency.

SEP99-SEP00

-Volunteer Student Professor

University of Pittsburgh School of Dental Medicine Served as a Restorative preclinical advisor to first year dental students while completing final year in dental school

AUG98-MAY99

-Dental Assistant

Katsur Dental

Pittsburgh, PA

Provided dental assisting duties for a 12 chair private practice

FEB97-JUN99

OTHER

EXPERIENCE
-Student dental anesthesiologist

1 year elective

University of Pittsburgh School of Dental Medicine 
Provided I.V. conscious sedation to dental patients in a clinical setting $50+$ documented cases

MAY98-MAY99

PROFESSIONAL ASSOCIATIONS

PRESENTATIONS

RECENT

RESEARCH

COURSES

TAUGHT

OTHER

DUTIES
-Member Academy of General Dentistry -Member Alpha Phi Omega-National Service Fraternity

-Provided continuing education to Ft. Benning DENTAC with the presentation

"Management of I.V. Sedation Complications" JULO0

-Conducted research and formulated a publishable paper titled

"Altered Sensations Following Mandibular Third Molar Extractions"

NOV99-JUL00

- Volunteer Student Professor

University of Pittsburgh School of Dental Medicine Served as a Restorative preclinical advisor to first year dental students while completing my final year in dental school

AUG98-MAY99

$-561^{\text {st }}$ MED CO (DS) Unit Movement Officer $-93^{\text {rd }}$ Medical Battalion Airlift Load Planning Officer $-561^{\text {st }}$ MED CO Airlift Load Planning Officer 